\title{
O RIO CAMBONGO-NEGUNZA E OS SEUS AFLUENTES: UM EXEMPLO DA COMPLEXIDADE DE PADRÕES DE DRENAGEM EM ANGOLA
}

\author{
ILÍDIO DO AMARAL ${ }^{1}$
}

\begin{abstract}
Resumo - Foi escolhida a bacia do rio Cambongo-Negunza, situada na zona centro-litoral de Angola, como exemplo da complexidade das redes hidrográficas naquele país. Desde as suas nascentes em maciços da Montanha Marginal (altitudes de mais de $2000 \mathrm{~m}$ ), o rio desce pela escadaria de aplanações até ao mar, ao qual chega por um troço de vale encaixado em rochas sedimentares. Revela nos diversos sectores, não só ele, mas também a maioria dos seus afluentes, traçados impostos por estruturas tectónicas - fracturas e falhas, geralmente em redes ortogonais. Longos troços quase rectilíneos do Cambongo-Negunza são outros testemunhos dessas influências (Cretácico-Quaternário).

A superfície de aplanação litoral, incluindo as praias levantadas (altitudes de cerca de 40 a 100m), rasoirando terrenos da Orla Sedimentar e do Maciço Antigo, sobe para leste, gradualmente, até um limite topográfico bem marcado, o da base (altitudes de cerca de 280 a $300 \mathrm{~m}$ ) dos contrafortes ocidentais de uma crista quartzítica NNE-SSW de perfil transversal dissimétrico - a serra do Engelo, com altitudes entre 1400 e $1700 \mathrm{~m}$-, também ela com falhas, sublinhadas por nascentes de águas termais.

Daquela superfície litoral, na faixa das rochas cristalinas emergem alguns relevos residuais com características de inselberge ou montes-ilhas, que levantam vários problemas, como o da extensão, para ocidente, das formações quartzíticas e do seu desmantelamento, o comportamento dos mesmos materiais nos processos complexos da génese e evolução da extensa linha regional de escarpas N-S contra as quais terminam as superfícies aplanadas da orla litoral. Nos calcários próximos da costa o rio Cambongo-Negunza tem um percurso subterrâneo, por galerias e grutas de grandes dimensões, exsurgindo pouco antes da pequena planície terminal. Não longe do seu vale são observáveis dolinas de vários tamanhos e superfícies lapiezadas. As condições climáticas revelam semi-aridez: a precipitação anual é inferior a $700 \mathrm{~mm}$, a evaporação é elevada, a cobertura vegetal é a de um mosaico de savanas, estepes e balcedos xerofíticos, com árvores dispersas ou sem elas.

Entre a serra do Engelo e os maciços da Montanha Marginal estende-se ampla área de afloramentos de rochas graníticas e afins, por vezes cobertas por rególitos de espessuras variadas. As altitudes da aplanação geral estão entre 1100 e $1200 \mathrm{~m}$.
\end{abstract}

1 Geógrafo. Professor Catedrático Jubilado da Universidade de Lisboa. Colaborador do Centro de Estudos Geográficos de Lisboa. Membro da Academia das Ciências de Lisboa e da Academia Portuguesa da História. E-mail: idoamaral@hotmail.com 
A área está coberta por bosques e savanas de árvores baixas, arbustos e capins altos sobre solos pouco espessos e muito variáveis, embora os fersialíticos sejam os mais vulgares. As temperaturas médias rondam os $22^{\circ} \mathrm{C}$ e a precipitação anual é de cerca de $1400 \mathrm{~mm}$. Em muitos locais são visíveis horizontes de lateritização ou bauxitização e couraças expostas.

Acima daquela superfície de aplanação elevam-se, abundantes, os relevos residuais do tipo inselberg, isolados ou agrupados; ligados ou não aos traçados geométricos das redes hidrográficas, com predomínio dos quadriculados, traduzindo a acomodação dos cursos de água, grandes e pequenos, permanentes e temporários, a fracturas e falhas. É de notar que a maioria dos inselberg não está na proximidade das vertentes escarpadas da Montanha Marginal, limites leste da superfície de 1100 $-1200 \mathrm{~m}$, mas bem mais para o lado ocidental, da crista quartzítica do Engelo. O mesmo sucede em bacias vizinhas, como a do Cuvo-Queve a norte e a do CubalQuicombo a sul. Vales de fractura e relevos residuais mereceram explanações de pormenor, com indicação de critérios para o seu estudo.

Mais uma vez houve a preocupação de correlacionar os vários factores de dinâmica externa (dito de modo simplificado, meteorização e erosão em sentido lato) e de dinâmica interna (geologia e tectónica) para explicar a génese e evolução das formas do relevo. Por isso mesmo o estudo termina com breves considerações para uma explicação geocronológica dinâmica.

Palavras-chave - Angola, geomorfologia, bacia do rio Cambongo-Negunza, geologia, padrões hidrográficos, superfícies de aplanação, relevos residuais, solos, vegetação.

\footnotetext{
Abstract - The CAmbongo-NegunZa River And its tributaries: AN EXAMPLE OF THE COMPLEXITY OF THE DRAINAGE PATTERNS IN ANGOLA. The hydrographical basin of River Cambongo-Negunza, situated in the coastal area of central Angola, was selected as an example of the complexity of drainage patterns in Angola. From its sources in the massifs of the Marginal Mountain (more than $2000 \mathrm{~m}$ ) the river flows through the stepped planed erosion surfaces to the Ocean. In its lower course the river valley presents a narrow and $\mathrm{V}$-shaped cross profile cut in sedimentary rocks (Cretaceous-Quaternary).

The coastal erosion surface, including the raised beaches (mean altitudes from 40 to $100 \mathrm{~m}$ ), levelling the rocks of the Sedimentary Belt and those of the ancient crystalline massif, gradually rises towards the east until a well marked topographical limit, the base (altitude approx. 280-300 m) of the steep western slopes of a NNE-SSW quartzitic ridge with a dissymmetrical cross-sectional profile: the serra do Engelo (altitudes between 1 400-1 700m), whose faults are peppered with thermal springs.

Above the coastal surface, in the crystalline rock strip, some quartzitic hills with Inselberge characteristics rise out of the plains, leading to problems in relation to, for example, the western extension of the quartzite formations and their dismantling, and the behaviour of the same material in the complex genesis and evolution processes of the extensive regional line of N-S escarpments, against which the erosion surfaces of the coastal belt end. In the limestones near the coast, the river Cambongo-Negunza has a subterranean network of large caves and galleries surfacing near the small plain from which it flows into the ocean. Not far from the valley sinks and dolines of various sizes and lapies can be seen. The climatic conditions are semi-arid, with annual precipitation less than $700 \mathrm{~mm}$ and high evaporation rates.
} 
O Rio Cambongo-Negunza e os seus afluentes:

um exemplo da complexidade de padrões de drenagem em Angola

Vegetation is a mix of that which can be found in savanna, steppe and xerophytic habitats, with few to no trees.

A vast area of outcrops of granitic and related rocks, sometimes covered by regoliths of various thicknesses, can be found between the Serra do Engelo and the massifs of the Marginal Mountain chain. The altitudes of the general levelling range between 1100 and $1200 \mathrm{~m}$. The area is covered by forest and savannas with low trees, shrubs and tall grasses growing in rather thin and variable soils, fersialitic being among the most frequent. The average temperature is around $22^{\circ} \mathrm{C}$ and annual rainfall is about $1400 \mathrm{~mm}$. Lateritisation or bauxitisation lines and subaerean duricrust can be seen in many places.

Above this surface, there are many Inselberge-type hills, isolated or in groups, mostly with square-shaped forms, linked or not to the geometrical patterns of the hydrographic networks, revealing the structural control of fractures and faults over these watercourses, whether small or large, permanent or temporary. Note that the majority of the Inselberge is not found near the escarpments of the marginal mountain chain, the eastern limit of the 1 100-1 200 metre-high plain, but rather quite a distance away to the west, near the Serra do Engelo quartzitic ridge. The same can be seen in the neighbouring basins of the River Cuvo-Queve to the north and to the south of the Cambongo-Negunza river basin.

Fracture valleys and residual hills call for more detailed explanations, with suggestions of criteria for their study. Moreover, there has been the concern regarding how to correlate several factors relative to external dynamics (meteorisation and erosion in a broad sense) with those relative to internal dynamics (geology and tectonics) to explain the genesis and evolution of the landforms. Therefore, the study wraps up with some brief thoughts regarding a dynamic geo-chronological approach.

Key words - Angola, geomorphology, hydrographical basin of the Cambongo-Negunza river, geology, hydrologic patterns, erosion surfaces, residual hills, soils, vegetation.

Résumé - Le CAmbongo-NegunZa et SeS AfFluents: un EXeMPle Des COMPLEXES RÉSEAUX DE DRAINAGE DE L'ANGOLA. Le bassin du Cambongo-Negunza, situé dans le centre littoral de l'Angola, exemplifie bien la complexité des réseaux hydrographiques de ce pays. Depuis ses sources, situées à plus de $2000 \mathrm{~m}$ dans la Montagne Marginale, la rivière descend jusqu'à la mer par un escalier de surfaces aplanies et s'encaisse à l'aval dans les roches sédimentaires. Le tracé du fleuve et de la plupart de ses affluents est commandé par un réseau orthogonal de failles et de fractures. De longs segments rectilignes résultent des mêmes influences tectoniques (Crétacé-Quaternaire).

La surface d'aplanissement littorale, qui incorpore des plages soulevées jusqu'à 40-100m, recoupe les terrains de la frange sédimentaire et du Massif ancien. Elle s'élève graduellement vers l'Est jusqu'à une limite nette, vers 280-300m, située à la base des contreforts occidentaux d'une crête de quartzite NNE-SSW, de profil transversal dissymétrique. La Serra do Engelo atteint 1400 à $1700 \mathrm{~m}$ et est aussi recoupée par des failles, ponctuées de sources thermales.

Quelques reliefs résiduels de type Inselberg émergent de la surface littorale et soulèvent divers problèmes, comme celui de l'extension vers l'ouest des formations quartzitiques, de leur démantèlement et de leur comportement face à l'érosion, qui permettraient d'expliquer la genèse et l'évolution du grand alignement d'escarpements N-S limitant la surface littorale. Le Cambongo-Negunza traverse les calcaires 
littoraux par un parcours souterrain, où se succèdent grottes et galeries, avant de ressurgir tout près de la petite plaine littorale. Des dolines de tailles variées et des surfaces lapiazées encadrent sa vallée. Le climat est semi-aride : précipitation annuelle inférieure à $700 \mathrm{~mm}$, évaporation élevée, mosaïque de savanes, steppes e buissons xérophytiques, avec ou sans arbres dispersés.

Entre la Serra do Engelo et la Montagne Marginale, s'étend un vaste espace de roches granitiques et apparentées, parfois couvertes d'un régolite plus ou mois épais. L'aplanissement s'étend entre 1100 et $1200 \mathrm{~m}$ et est couvert par des bois et savanes de petits arbres, arbustes et hautes herbes, sur des sols peu épais et très variés, souvent fersialitiques. Les températures moyennes sont d'environ $22^{\circ} \mathrm{C}$ et les pluies annuelles de $1400 \mathrm{~mm}$. Des horizons de latéritisation ou bauxitisation et des cuirasses affleurantes sont fréquents.

Des reliefs résiduels de type Inselberg, isolés ou groupés, se dressent souvent au dessus de la surface. Certains sont liés aux tracés géométriques et souvent quadrangulaires que dessinent les cours d'eau. On note que la plupart des Inselbergs ne se situent pas à proximité du versant escarpé de la Montagne Marginale, mais plus à l'ouest, près de la crête quartzitiques de l'Engelo. Il en est de même dans les bassins voisins du Cuvo-Queve, au nord, et du Cubal-Quicombo, au sud. L'étude détaillée des vallées de fracture et des reliefs résiduels est présentée, ainsi que des indications sur les méthodes d'étude employées, où l'on a tenté de corrélationner les divers facteurs de dynamique externe et interne. Finalement, une brève explication géochronologique de l'évolution des formes est proposée.

Mots-clés - Angola, géomorphologie, basin hydrographique de la CambongoNegunza, géologie, types de réseaux hydrographiques, surfaces d'érosion, reliefs résiduels, sols, vegétation.

Em Angola é muito frequente a utilização de dois ou mais nomes para um rio, consoante os sectores dos seus percursos. Escolhemos, entre os casos estudados com algum pormenor, a bacia do Cambongo-Negunza, designado pelo segundo nome na sua parte litoral, mas mais conhecido pelo primeiro nos sectores médio e superior (figs 1 a 3 ). De modo idêntico se passa com outros rios e os seus afluentes mais importantes, como sucede com os dois entre os quais se situa a bacia do Cambongo-Negunza, isto é, o Cuvo-Queve ao norte e o Cubal-Quicombo ao sul. Sublinhamos, desde logo, a enorme complexidade dos traçados fluviais, quer no sector litoral, mais perto do Oceano, onde os elementos da bacia do Cambongo-Negunza atravessam uma faixa de cerca de $28 \mathrm{~km}$ de largura de materiais mesozóicos e posteriores da Orla Sedimentar, quer no interior, muitíssimo mais vasto, de rochas precâmbricas, metamórficas e eruptivas do Maciço Antigo (fig. 2) ${ }^{2}$.

O Cambongo nasce nos contrafortes da Montanha Marginal, com bacias afluentes em altitudes superiores a $2000 \mathrm{~m}$, por cerca da latitude de $11^{\circ} 39^{\prime}$ e da longitude de $14^{\circ} 46^{\prime}$, ficando o seu tronco principal encaixado numa fractura entre os maciços de Quimbumba (2 279m) a norte e de Gonga (2 316m) a sul, aberta

2 As figuras a cores aparecerão na edição electrónica (www.ceg.ul.pt/finisterra/index.htm) 


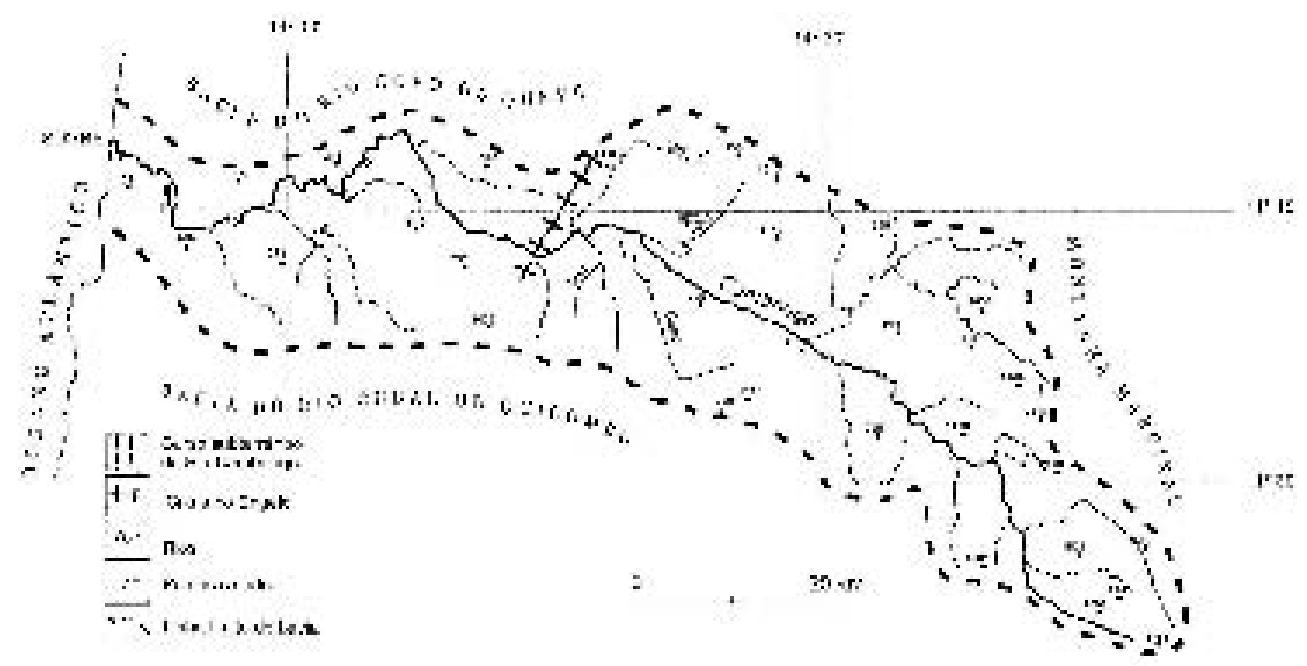

Fig. 1 - A bacia do rio Cambongo-Negunza entre as dos rios Cuvo ou Queve e Cubal ou Quicombo, e a Montanha Marginal.

Fig. 1 - The Cambongo-Negunza river basin, between those of the Cuvo or Queve and Cubal rivers and the Marginal Mountain.

em rochas do complexo gnáissico-migmatítico-granítico, elementos de uma parte do rebordo montanhoso que, ao longo de longitudes em torno de $14^{\circ} 40^{\prime}$, ainda conta com Chiuale $(2016 \mathrm{~m})$ e Uassamba $(2083 \mathrm{~m})$, ao sul do rio Cuvo-Queve, Golungo (2 278m), Comongo (2 033m), e Namba (2 147m), este na margem direita da bacia do Cubal-Quicombo. Nesse rebordo ocidental de empolamento montanhoso recebe, na margem direita, os primeiros afluentes importantes, o Candunga-Cuvele, que também aproveita fracturas, e o Luambimbe, que está instalado, antes de passar por Amboíva, em falhas SE-NNW. De resto, o Luambimbe e o Cambongo delimitam um bloco de Montanha Marginal (com o Quimbumba, $2279 \mathrm{~m}$, entre eles) muito fracturado. Na área da sua confluência, a sudoeste de Amboíva, os dois rios têm contribuído para o enchimento de uma depressão com materiais eluvionares nos quais, por vezes, se encontram bancadas lateriticas.

$\mathrm{Na}$ sua terminação atlântica, já com a designação de Negunza, o Cambongo desagua junto de Sumbe ou Negunza Cabolo, ex-Novo Redondo (latitude e longitude aproximadas de $11^{\circ} 11^{\prime}$ e de $\left.14^{\circ} 50,5^{\prime}\right)$, meandrando em pequena planície aluvial rodeada por arribas de rochas essencialmente margosas, claras ou acinzentadas, por vezes esverdeadas ou acastanhadas, e quase fechada, do lado do mar, por um cordão de areias quartzosas de praia, de granulometria fina a média.

A existência de excelentes folhas das cartas topográfica e geológica na escala de 1:100 000, que cobrem toda a área da bacia do rio, tendo as segundas as respectivas notícias explicativas, de mosaicos de fotografias aéreas estereoscópicas na escala aproximada de 1:40 000 e de cartografia pedológica, muito contribuiu para a melhor compreensão dos aspectos observados em vários per- 


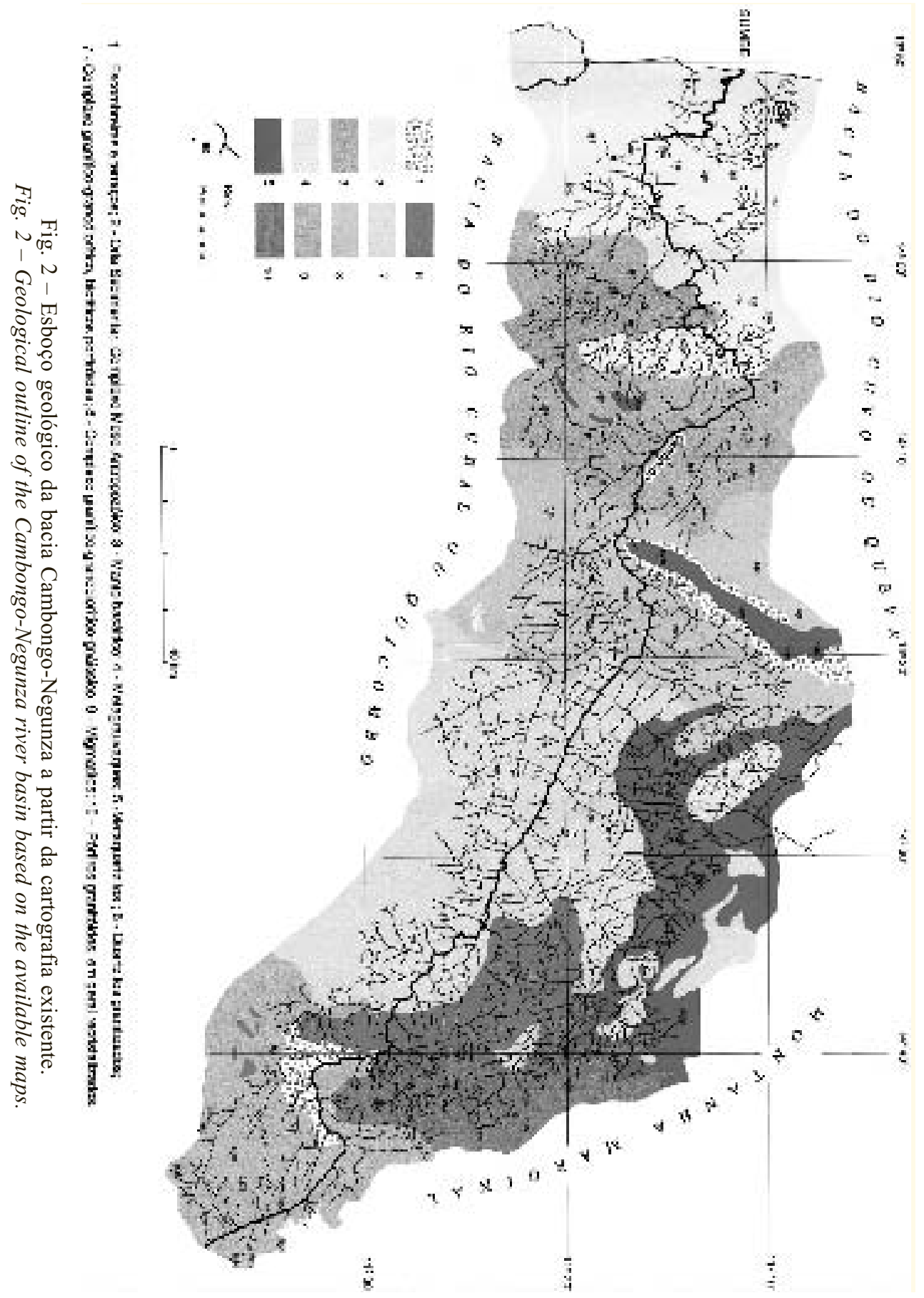




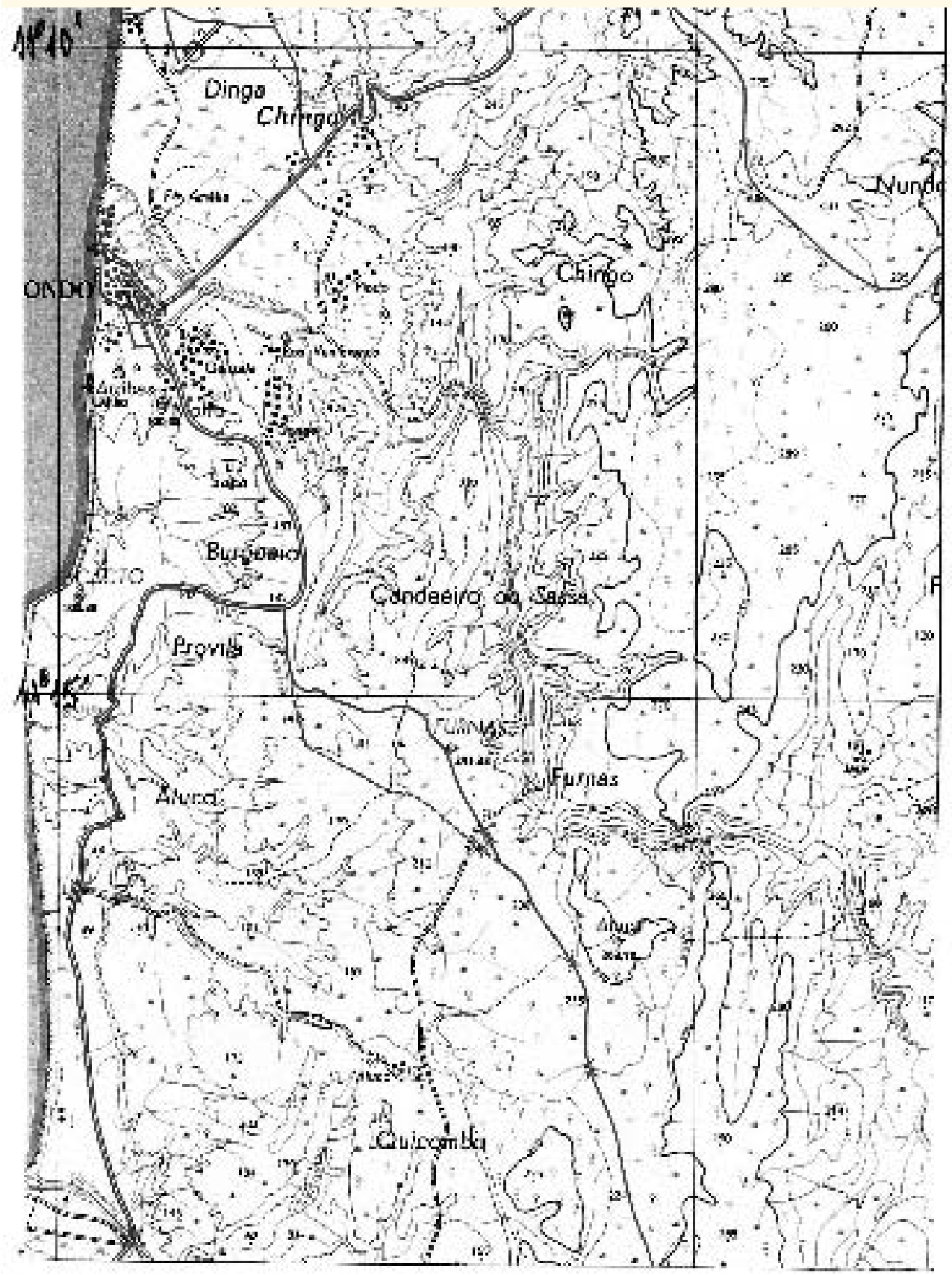

Fig. 3 - Parte terminal do rio Cambongo-Negunza, Furnas e dolina, entre lat. $11^{\circ} 10^{\prime}$ e long. $13^{\circ} 50^{\prime}$ e $13^{\circ} 55,5^{\prime}$.

Fig. 3 - Final part of the Cambongo-Negunza river, Furnas and dolina (A), between lat. $11^{\circ} 10^{\prime}$ and long. $13^{\circ} 50^{\prime}$ and $13^{\circ} 55,5^{\prime}$. 
cursos no terreno e a formulação de algumas hipóteses sobre a evolução da bacia hidrográfica, das formas do relevo e dos processos da sua elaboração. Por uma questão de ordenamento legível das informações começaremos, não da Montanha Marginal para o Atlântico mas, contrariamente, do litoral para o interior, conjugando, tanto quanto possível, a geomorfologia com a geologia e a pedologia, sem esquecer o recurso às coberturas de vegetação.

\section{ASPECTOS GEOLÓGICOS E GEOMORFOLÓGICOS}

O rio Cambongo-Negunza chega à sua pequena planície aluvial através de uma vale encaixado e relativamente estreito aberto em rochas sedimentares. As mais próximas do litoral, atribuídas ao Cenomaniano-Turoniano, são essencialmente margosas, com finas intercalações de natureza calcária ou gresosa de 1 a $5 \mathrm{~cm}$ de espessura, que também formam as arribas que se estendem para norte e para sul da foz do rio. De onde em onde notam-se dobras de pequena amplitude. Nos locais de maior frequência e coerência das intercalações calcárias, estas têm resistido à erosão, dando lugar ao aparecimento de relevos tabulares, como sucede a norte do aeroporto de Sumbe. Também são visíveis terraços marinhos, uns de altitudes inferiores a $40 \mathrm{~m}$, com areias argilosas de tons claros ou avermelhados, e outros muito mais altos, servindo de exemplo o pequeno planalto a sueste do vértice Furnas, com $241 \mathrm{~m}$ de altitude (fig. 3).

Em regra geral o conjunto acima referido assenta em rochas classificadas como do Albiano médio a superior, havendo locais, porém, em que o contacto é feito por discordância ou por falha. Do topo para a base, e pela ordem de afloramento, distinguem-se calcários margosos e margas calcárias de cores claras, bastante fossilíferas; calcários dolomíticos e dolomias gresosas; arenitos com cimento carbonatado, umas vezes de grão fino a médio, outras vezes grosseiro, com passagem a conglomerático, tendo ainda intercalações de níveis dolomíticos; conglomerados; dolomias compactas, por vezes com alguns níveis gresosos, que apresentam, com frequência, um aspecto cavernoso e dão um solo do tipo terra rossa. Estas dolomias estão cobertas, geralmente, por vegetação densa, rica em euforbiáceas, ao contrário de outros afloramentos calcários, onde ela se reduz a pequenas gramíneas.

$\mathrm{Na}$ escala geológica seguem-se rochas do Albiano inferior, que contactam, por discordância ou por falha, com as do Apciano superior. No primeiro caso são de natureza dominantemente laguno-continental, constituídas por margas calcárias e margas siltosas, areias e arenitos avermelhados, conglomerados, margas argilosas matizadas, mas predominando os tons vermelhos, gesso e anidrite, com algumas intercalações margosas. Em vários locais os leitos maciços de gesso e anidrite afloram com desenvolvimento superior a $150 \mathrm{~m}$, expostos na sequência de processos diapíricos ligados a falhas. No segundo caso estão calcários compactos com dentrites e intercalações de calcários oolíticos; calcários margosos claros; calcários escuros e avermelhados, ricos em óxidos de ferro e 
manganés; arenitos, frequentemente micáceos e conglomeráticos, com matriz argilosa avermelhada, e conglomerados de grandes blocos (diâmetros de 1 a $2 \mathrm{~m}$ ) pouco rolados, o que denuncia fraco transporte.

Por estes materiais conglomeráticos se estabelece o contacto com as formações do Maciço Antigo, de uma faixa de rochas predominantemente migmatíticas, de grão fino a médio, com injecções graníticas (granitos porfiróides com grandes cristais de feldspato), destacando-se ainda, no meio delas, alguns afloramentos de quartzitos e de rochas filonianas, a que se segue, para oriente, uma mancha do complexo granítico-granodiorítico-gnáissico. São observáveis fracturas próximas de $\mathrm{N} 20^{\circ} \mathrm{E}$, valor correspondente a uma direcção importante de tectonismo regional. Há também afloramentos de basaltos olivínicos, posteriores ao Albiano inferior pois que, nalguns lugares, eles cobrem e cortam esse nível.

Uma grande mancha de rochas que, por ora, diremos graníticas e afins rodeia uma crista quartzítica, a serra do Engelo, o elemento de relevo mais saliente e vigoroso da parte ocidental da bacia do Cambongo-Negunza (figs 2, 4 e 5). Com os seus contrafortes figura como limite do conjunto de superfícies aplanadas cujas altitudes médias vão tendo valores crescentes para leste, desde os cimos das arribas litorais até os de cerca de $300 \mathrm{~m}$. Orientada NNE-SSW - entre as latitudes aproximadas de $11^{\circ} 06^{\prime}$ e $11^{\circ} 19^{\prime}$ e as longitudes de $14^{\circ} 15^{\prime}$ ' (a ponta meridional) e $14^{\circ} 20^{\prime}$ ' (a setentrional) -, a crista tem um comprimento de perto de $23 \mathrm{~km}$ e é ligeiramente arqueada; as suas altitudes são de 1620 a $1680 \mathrm{~m}$ (o ponto mais alto) no terço setentrional e de cerca de 1410 a $1430 \mathrm{~m}$ no terço meridional (figs 2 e 4). O perfil transversal é dissimétrico. As vertentes ocidentais dominam mais bruscamente a topografia que as rodeia, primeiramente de um patamar rugoso, com inselberge ou montes-ilhas, sobretudo a norte, em rochas do complexo granítico-granodiorítico-gnáissico. O patamar tem uns $10 \mathrm{~km}$ de largura e inclina para sul (altitudes rondando os $1100 \mathrm{~m}$ na parte setentrional e $900-950 \mathrm{~m}$ na meridional) e para ocidente (600$-700 \mathrm{~m}$ ), e dele se passa, por um degrau bastante recortado, com vários esporões, para o conjunto de superfícies de cerca de $300 \mathrm{~m}$ de altitude, anteriormente referidas, modeladas na faixa de rochas migmatíticas, com continuação e ligeira descida para ocidente, sobre as rochas da Orla Sedimentar. As vertentes orientais, juntamente com as escombreiras de sopé, têm declives menos abruptos, ligando-se a uma topografia rugosa, com inúmeros inselberge ou montes-ilhas, agrupados, sobretudo, numa larga faixa NW-SE, que é a da bacia do Cambongo. Trata-se da passagem para as superfícies de $1100-1200 \mathrm{~m}$, em rochas graníticas e afins, acima das quais se eleva, a norte, o maciço grauváquico de Capanga (1 630 e $1645 \mathrm{~m}$ nos pontos mais altos, situados a sul) que, na sua área, marca a separação entre as bacias do Cambongo e do Cuvo. Voltaremos a estes assuntos mais adiante.

Numa perspectiva muito mais vasta do território angolano, a crista quartzítica é apenas um pequeno elemento da longa cadeia de escarpas que, podemos dizer quase sem exagero, se estende do Zaire ao Cunene. Reduzindo a nossa visão à área entre os rios Cuvo e Quicombo, que inclui o Negunza, na linha N-S de escarpas vigorosas, a cerca de $40-50 \mathrm{~km}$ em linha recta da orla litoral - um pouco mais na latitude da Ponta do Morro (Porto Amboím), onde ultra- 


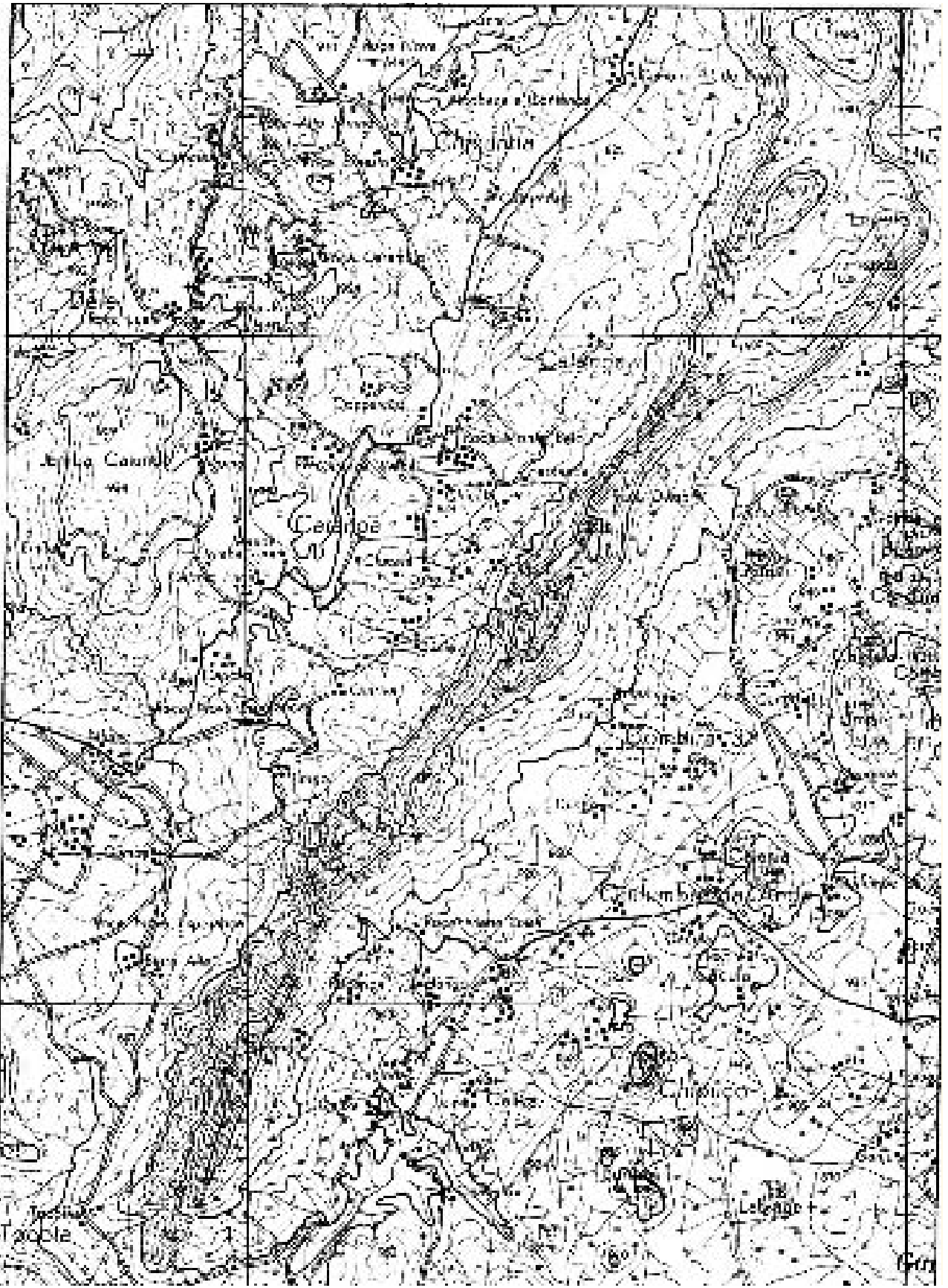

Fig. 4 - A serra do Engelo, entre lat. $11^{\circ} 10^{\prime}$ e $11^{\circ} 15^{\prime}$ e long. $14^{\circ} 15^{\prime}$ e $14^{\circ} 20$ '.

Fig. 4 - Engelo mountain, between lat. $11^{\circ} 10^{\prime}$ and $11^{\circ} 15^{\prime}$ and long. $14^{\circ} 15^{\prime}$ and $14^{\circ} 20^{\prime}$ 
$\bullet$

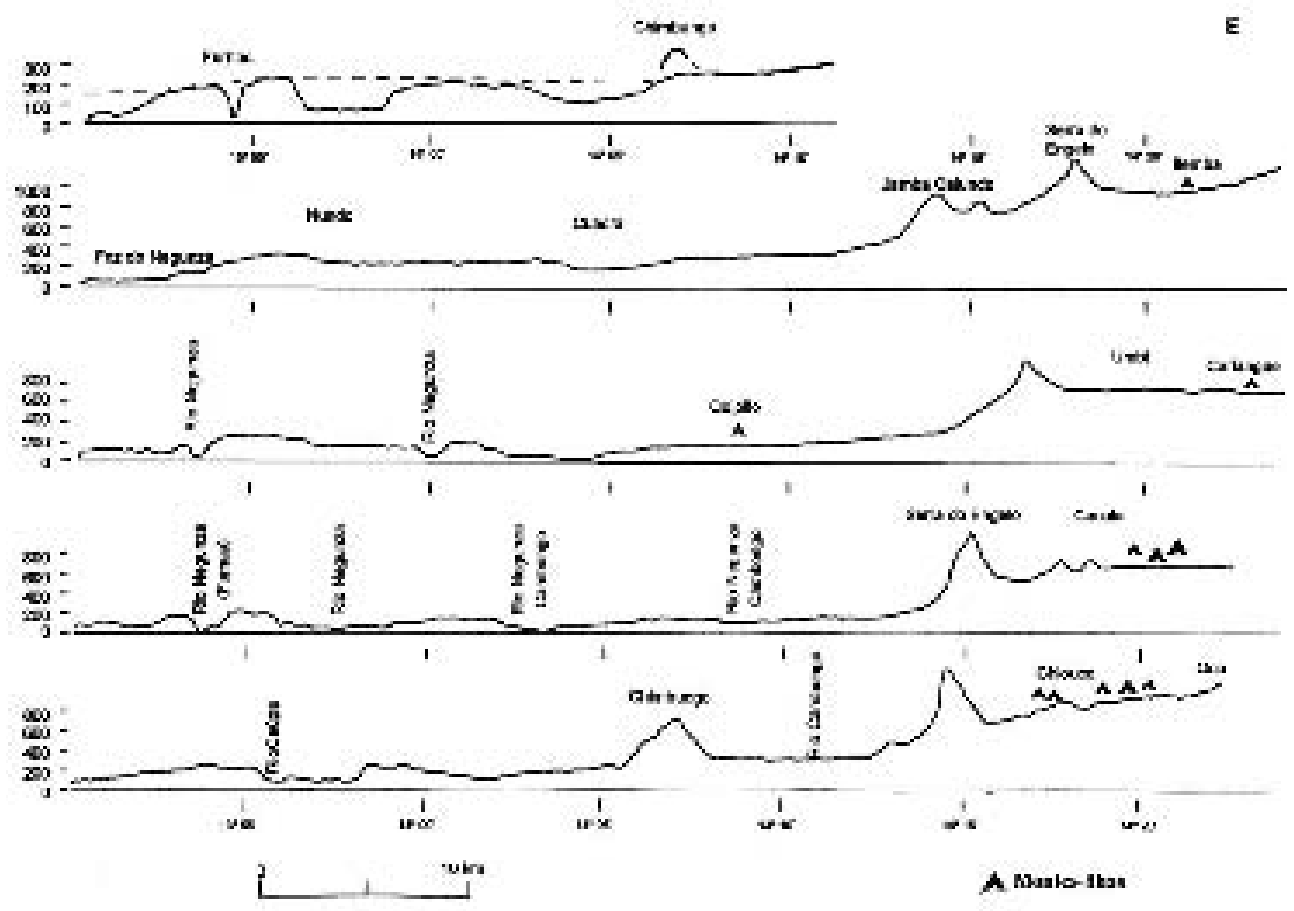

Fig. 5 - Perfis topográficos do litoral à serra do Engelo

Fig. 5 - Topographic profile of the littoral part of Engelo mountain

passa os $50 \mathrm{~km}$, dada a inflexão da linha litoral para oeste, e muito mais na latitude da foz do rio Longa -, com a qual mantém um certo paralelismo, a serra do Engelo, com os seus $1680 \mathrm{~m}$ de altitude máxima e porte vigoroso, ganha inegável importância regional. Como ela confere a possibilidade de distinguir, nos limites da bacia do Cambongo-Negunza, um quadro de formas de relevo para ocidente, nitidamente diferente do que lhe fica para oriente, tentemos por ora destacar alguns dos aspectos mais interessantes do primeiro.

\section{NOTAS SOBRE O RELEVO A OCIDENTE DA SERRA DO ENGELO}

A visão que se impõe é a da vastidão de superfícies aplanadas por processos que as rasoiraram quer nos materiais da Orla Sedimentar, quer nas rochas migmatíticas do Maciço Antigo, desde os cimos de arribas litorais (altitudes em torno de $100 \mathrm{~m}$ ), talhadas em formações margosas e calcárias, aos contrafortes graníticos da serra do Engelo. Na cartografia topográfica de 1:100 000 a curva de nível de $250 \mathrm{~m}$ delimita, conspicuamente, retalhos planálticos até próximo da base da serra (figs 3 a 5). 
O rio Cambongo, depois de um longo percurso de sueste para noroeste, quase rectilíneo, de mais de $30 \mathrm{~km}$, em terrenos graníticos (granitos, granodioritos e gnaisses) biotíticos porfiróides, encurva para sudoeste, arrimado ao terço terminal da crista, até contornar a sua extremidade, e avançar para ocidente em vale aberto nas rochas migmatíticas das aplanações dos $300 \mathrm{~m}$, passando a receber numerosos afluentes (fig. 2). Naquele troço em que contorna a serra o rio corre, numa distância de pouco mais de $2,5 \mathrm{~km}$, da cota de $500 \mathrm{~m}$ para a de 350 num vale encaixado e dissimétrico, com a margem direita modelada, do cimo (altitudes em torno dos $1250 \mathrm{~m}$ ) para baixo, nos quartzitos, nas escombreiras da crista (entre cotas de 550 e $650 \mathrm{~m}$ ) e nas rochas graníticas; e a margem esquerda apenas nestas, onde os cimos das vertentes ultrapassam em pouco altitudes de $830 \mathrm{~m}$.

No conjunto da área a ocidente da serra do Engelo, em certa medida, a rede hidrográfica concorda com os declives gerais das aplanações. Menos densa, mas sensível a faixas de fraqueza estrutural nos terrenos encobertos do complexo migmatítico, ela é muito mais densa e dendritificada nos da Orla Sedimentar, onde o Cambongo-Negunza e cada um dos seus afluentes, profusamente ramificados, têm traçados tortuosos, demasiado complicados, sobre rególitos mais impermeáveis.

A Orla Sedimentar, cujas formações têm uma inclinação geral para ocidente, está marcada por fracturas e falhas de direcções dominantes N-S, cortadas por outras NNE-SSW que, de certo modo, condicionaram os traçados de elementos da rede fluvial, nomeadamente do colector principal, o Cambongo-Negunza. $\mathrm{O}$ facto está bem evidenciado nos dois ramos que formam um ângulo recto no local das Furnas (latitude e longitude de cerca de $11^{\circ} 16^{\prime}$ e $13^{\circ} 54^{\prime}$, respectivamente), encaixados na faixa de calcários gresosos e conquíferos, dolomias gresosas, arenitos e conglomerados do Albiano médio a superior. Aí o rio, logo a seguir ao tramo de E-W, tem uma imergência, com queda espectacular, passando a ter, no tramo S-N (fig. 3), um percurso subterrâneo de cerca de $600 \mathrm{~m}$, com enorme gruta e suas partes anexas, ornadas com estalactites e estalagmites. Este tramo, igualmente encaixado, segue uma caixa de falha, aberta numa junção estrutural de dobra complicada que, embora encurvada, tem essa orientação geral. O rio abandona-a ao fim de poucos quilómetros, no contacto por falha com um pequeno bloco de rochas do Albiano inferior, para tomar a direcção do mar, passando ainda por um conjunto de falhas prováveis.

A gruta e os seus anexos constituem os elementos mais espectaculares do carso subterrâneo do Negunza, havendo ainda as formas de superfície, em especial as dolinas, bem marcadas na paisagem. Mariano Feio, numa breve nota deu conta do fenómeno do Negunza nas Furnas. Coincidindo as suas observações com as que registámos em caderno de campo durante pesquisas efectuadas em anos anteriores à sua passagem pelo local, seguiremos de perto o seu texto (Feio, 1982), reproduzindo alguns excertos. Antes de mergulhar o rio corre num troço de vale em $V$ apertado, por cerca de $3,5 \mathrm{~km}$, orientado de leste para oeste; o encaixe ronda os $170 \mathrm{~m}$ abaixo da superfície de 270-280m de altitude. Bruscamente, o Negunza toma o rumo para norte, orientado por uma fractura e é no cotovelo formado pelos dois troços que as águas, com grande velocidade, mergulham na furna, aberta na 
base de um profundo funil com cerca de $135 \mathrm{~m}$ de altura, de forma circular, com perto de $170 \mathrm{~m}$ de diâmetro na parte superior. Tudo leva a crer que se trata de uma dolina cujo fundo abateu. Nessa furna há dois níveis ou patamares: o inferior, sempre encoberto pelas águas do rio, e o superior, em alturas de cheias; ambos os patamares revelam as falhas correspondentes. $\mathrm{O}$ declive do percurso subterrâneo é da ordem dos $6 \%$ até à extremidade do troço $\mathrm{S}-\mathrm{N}$, onde o rio alcança a planície aluvial, que está pouco acima do nível do mar.

Voltando ao sítio Furnas, são visíveis testemunhos de um curso anterior, certamente de antes do rio seguir o trajecto subterrâneo. Uma portela à cota aproximada de $120 \mathrm{~m}$, "corresponde a um ponto do fundo do vale que foi abandonado" quando o Negunza "tomou o trajecto subterrâneo: para juzante da portela conserva-se mais um troço do curso daquele tempo, na forma de um declive forte, da ordem dos $6 \%$ durante $1100 \mathrm{~m}$; tratava-se, pois, de um rápido longo e inclinado. Estas partes abandonadas do curso antigo deixaram praticamente de evolucionar por terem ficado" sem águas (Feio e, ainda, nas citações seguintes).

"A grande dolina/algar estabeleceu um caminho para as águas, se não mais fácil, pelo menos localmente com maior declive e começou a atrair as águas do rio; o caminho pelo algar foi-se desenvolvendo, por dissolução e a favor das fracturas, a ponto de chamar a si todo o caudal do rio: deu-se assim uma espécie de captura na vertical, tomando as águas o trajecto subterrâneo e ficando em seco o antigo rápido. A parede da dolina/algar deve-se ter ido esboroando, até estar completamente destruída, como hoje acontece do lado do rio; durante este processo, o rio foi rebaixando o curso para montante, por erosão regressiva normal, certamente por a proporção de calcários não ser aqui suficiente para se estabelecer um curso subterrâneo; observam-se todavia testemunhos de uma circulação subterrânea em formação, representada por restos de três dolinas para montante das Furnas, mesmo à beira do vale e esventradas por ele. Para jusante delas, também se encontra uma dolina, mas esta um funil perfeito, embora de fundo dissimétrico, com cerca de $300 \mathrm{~m}$ de diâmetro e $35 \mathrm{~m}$ de fundo, ainda completa apesar de estar mesmo à beira do precipício. Cerca de $2 \mathrm{~km}$ ao montante da estrada das Furnas, encontra-se um meandro abandonado, mais ou menos a meia altura da vertente actual, que testemunha também uma posição de encaixe próxima daquela em que o rio corria na portela."

Acerca das dolinas, tomaremos como exemplo algumas observadas numa superfície de 270-280m de altitude, nos mesmos calcários das Furnas, distando destas cerca de $2-3 \mathrm{~km}$ para nordeste (fig. 3), cuja evolução foi favorecida por se situarem sobre o fecho de uma estrutura sinclinal. Aproveitamos a ocasião para nos debruçarmos um pouco mais sobre a génese e desenvolvimento de tais depressões cársicas, o que não fizemos nos estudos dos carsos da Nova Caipemba e da Humpata (Amaral, $1973 a$ e $b$ ). Os tamanhos e as formas das dolinas dependem de vários factores, entre os quais mencionamos a constituição e estrutura das rochas carsificáveis - porosidade, planos de estratificação, densidade da rede de fissuras, fracturas -, a composição química das soluções atacantes, a existência, a posição e a variabilidade de um aquífero subcutâneo ou epicár- 
sico, acrescentando ainda os factores paleogeológicos e paleoclimáticos. Mas não basta ficar por aqui.

A primeira constatação é a de que a existência de dolinas implica modos particulares de maior desgaste da rocha nas suas partes centrais por via da carsificação (dissolução) e evacuação dos produtos através de poços naturais ou algares. Pode-se imaginar que, à partida, a rocha carsificável esteve encoberta por rególito, controlador da taxa de infiltração. É sabido como, numa faixa superficial da rocha, de cerca de 5 a $10 \mathrm{~m}$ de espessura, os poros, as fissuras e as juntas se abrem mais amplamente à circulação das soluções e que, para lá desse limite, em profundidade, fissuras e juntas, de uma maneira geral, se apresentam fechadas, retardando ou dificultando a percolação. Daí o facto das partes mais cimeiras da rocha sob o rególito - sem esquecer que este, armazenando humidade, também contribui para a manutenção de processos de dissolução aparecerem fortemente corroídas, até uma faixa subcutânea de infiltração e circulação de águas cujo limite inferior é a superfície do maciço rochoso, onde a maioria das juntas permanece fechada e a barreira à capilaridade evita a rápida percolação. Formam-se assim aquíferos suspensos, com efeitos epicársicos (Mangin, 1974 e 1975).

Dada a variabilidade espacial da permeabilidade das juntas, podem desenvolver-se vias verticais de escoamento das soluções a partir da base da faixa subcutânea, que se tornam caminhos preferidos e se, por eles, a escorrência vertical adquirir grande volume e regularidade, resultará uma depressão na toalha de água subcutânea semelhante à dos cones à volta de um poço bombeado (Williams, 1983 e 1985). A drenagem no aquífero epicársico ajustar-se-á então às linhas de escorrência convergentes ou centrípetas nesses pontos ou planos fulcrais, contribuindo assim para o aumento da corrosão e permeabilidade verticais. Tudo isso se repercutirá na modelação e conservação das dolinas (aumento dos fluxos laterais, subparalelos às margens) e do seu tamanho (aumento da área de represamento das águas e, por conseguinte, maiores descargas). A existência de uma ou mais juntas abertas até grandes profundidades, em ligação com canais subterrâneos, faz com que os processos mencionados, de dissolução e escoamento dos produtos, ganhem maior actividade.

Há aspectos aparentemente contraditórios que marcam a evolução das dolinas. Por um lado, sucede que partes do rególito, fragmentos rochosos e detritos orgânicos, tendem a deslocar-se sobre as vertentes, por força da gravidade, e a acumular-se no fundo de tais depressões; entretanto, ficando as suas bordas exauridas de solo, aí o desgaste cársico poderá desacelerar-se. Por outro lado, no fundo da depressão, com a terra rossa, formam-se solos espessos retentores de humidade, onde se intensificam as actividades bioquímicas, com produção de anidrido carbónico, e os processos de corrosão na faixa de contacto com a rocha. Mas os solos espessos, sobretudo os de forte componente argilosa, também poderão diminuir a permeabilidade no fundo das dolinas, ao vedarem as aberturas das juntas; é vulgar formar-se, após as grandes chuvadas, uma faixa saturada de água por cima do aquífero epicársico. 
Com o aumento de condutas de drenagem vertical - fendas, chaminés ou poços -, perto do fundo das dolinas, os fluxos laminares nas vertentes tendem a ganhar regimes turbilhonares e a velocidade crescente do movimento das águas aumentará o transporte mecânico de partes do solo e partículas de rocha, evacuando-as subterraneamente. Este regime de drenagem através de fendas e chaminés ou poços estimulará abaixamentos da toalha de água subcutânea e, com isso, a expansão dos raios de influência dos sistema de drenagem centrípeta.

É evidente que há limites para o desenvolvimento das dolinas. Em condições de terreno aplanado, sob ambientes húmidos, com fornecimento espacialmente uniforme de água e onde se tenha desenvolvido, na faixa subcutânea, uma permeabilidade horizontal de certo modo uniforme, as características da toalha de água epicársica (tamanho, forma e posição relativa) serão determinadas, localmente, pela magnitude das diferenças das descargas hidráulicas verticais até à massa rochosa profunda pouco ou nada meteorizada.

Não se desenvolverão as dolinas nos casos em que o movimento de águas na vertical, através da zona vadosa, for tão grande que apenas ocorra armazenagem subcutânea fraca ou de curta duração; a permeabilidade vertical for tão espacialmente uniforme que não se desenvolvam cones depressionários na toalha de água subcutânea; de vertentes declivosas, acima de $20^{\circ}$, onde o gradiente hidráulico subcutâneo dominante é subparalelo à superfície topográfica. Mas em superfícies suavemente inclinadas podem desenvolver-se dolinas assimétricas, com as margens mais abruptas voltadas para a vertente (Williams, 1985).

Há casos de aumento do tamanho e de modificação da forma das dolinas por colapso gradual do fundo, associado, por exemplo, com a passagem ainda activa ou abandonada de um rio subterrâneo por galeria ou gruta cujo tecto vai abatendo. Este tipo de colapso ocorre, geralmente, quando se entrecruzam o aprofundamento da dolina e a evolução ascendente de uma galeria ou gruta sob ela. A dolina mostra um fundo com sinais nítidos de abatimento e as vertentes com perfis de dois sectores: nas partes superiores, os aspectos marcantes de uma depressão de dissolução, e, nas partes inferiores, os de colapso.

É provável que os processos subcutâneos responsáveis pela génese das dolinas se tornem menos relevantes à medida que a topografia evolui, dependendo, em grande parte, da influência do factor climático. Dado tempo suficiente, os fundos das dolinas começam a aproximar-se da toalha freática regional e o aquífero subcutâneo emerge com ela. Quando isto ocorre, a água escapa-se mais na horizontal do que verticalmente na base das dolinas. Na sequência disso, o seu aprofundamento desacelera rapidamente e os seus chãos acabam por adquirir os aspectos de plainos de corrosão.

Ao referirmos o factor climático não podemos deixar de levantar o problema da evolução das dolinas em relação com a semiaridez que caracteriza a orla litoral do Negunza: total anual de precipitação inferior a $700 \mathrm{~mm}$, época chuvosa de Outubro-Novembro a Abril, quantidade média do mês mais chuvoso entre 142 e $231 \mathrm{~mm}$, com máximo absoluto em Março-Abril e secundário em Novembro, mínimo absoluto em Junho e/ou Julho $(0$ a $6 \mathrm{~mm})$ e secundário 
num dos meses do trimestre de Dezembro a Fevereiro; época seca de Maio a Setembro-Outubro, tendo o primeiro mês características de transição entre as duas épocas do ano; humidade relativa do ar às $9 \mathrm{~h}$ entre 63 e $88 \%$; evaporação elevada; vegetação bastante escassa nos terrenos margosos, mas mais rica nos calcários e dolomias, e sobretudo junto dos cursos de água permanentes, predomínio de uma cobertura graminosa associada a solos argilo-arenosos. De uma maneira geral pode-se classificar a cobertura vegetal como um "mosaico de savanas, estepes e balcedos xerófitos, com ou sem árvores dispersas, sublitorais" (Barbosa, 1970). Sem termos tido tempo para observações locais demoradas e sem existirem postos udométricos com medições regulares, julgamos que o problema se pode pensar nos parâmetros anteriormente descritos, de que destacamos a presença de um aquífero epicársico.

As rochas da área sobre a qual nos debruçamos, pelas suas características litológicas - calcários diaclasados e fracturados, grés, por vezes conglomeráticos, com alguns níveis arenosos -, oferecem condições para a constituição de aquíferos suspensos ou de nível relativamente baixo, que não andará longe do correspondente ao dos cursos de água permanentes (no caso específico o Negunza). Por outro lado, na base daquelas rochas estão, geralmente, camadas impermeáveis, margosas, ricas em gesso e anidrite.

Passemos a outros tipos de depressões. Ainda que não estejam bem no interior da área restrita da bacia do Cambongo-Negunza, não queremos deixar de referir a existência, muito perto dela, de estruturas em $X$, próprias a fenómenos diapíricos. A fracturação e deslocação por falhas dos calcários compactos e dolomias (Albiano médio) que cobriam as areias, conglomerados e margas argilosas ricas em gesso e anidrite (Albiano inferior), trouxeram estas para posições subaéreas, expostas assim ao ataque dos processos erosivos, que nelas aprofundaram as depressões de origem tectónica. Deste modo se explicam várias destas formas topográficas, de que a chamada Baixa do Algodão, junto da estrada Sumbe ou Negunza-Cabolo-Gabela, constitui um bom exemplo.

No que toca a formas escavadas ocorre-nos citar o testemunho de uma pequena depressão periférica na passagem da Orla Sedimentar para a faixa migmatítica, bem visível entre Cuacra e Chilembe, tendo como limite ocidental uma pequena linha N-S de costeiras, cujas frentes ostentam cornijas talhadas em dolomias e calcários compactos, que dominam sectores côncavos modelados em areias, conglomerados e margas argilosas; a depressão, embora pouco profunda, toma forma com a linha de frentes das costeiras a ocidente (cimos de 270-280m de altitude) e, do outro lado, com a superfície talhada em rochas migmatíticas que, saindo debaixo das formações sedimentares, se eleva para oriente. Por vezes o contacto é feito por falha.

Antes de passarmos ao ponto seguinte não podemos deixar de mencionar a existência de algumas pequenas cristas quartzíticas, dos mesmos metaquartzitos da crista do Engelo, estiradas paralelamente a esta e a jusante dela, no meio de topografias modeladas nas rochas migmatíticas forradas por espessuras variadas de materiais meteorizados e solos, próximas do contacto destas 
com as formações da Orla Sedimentar. Pelas suas altitudes e massas dominam os plainos cujas cotas rondam os $250-300 \mathrm{~m}$. Junto do limite norte da bacia do Negunza ergue-se o conjunto do Ungorré ( $366 \mathrm{~m}$ de altura máxima), um pequeno alinhamento NNE-SW de três afloramentos principais; muito mais para sul e dentro da área daquela bacia elevam-se o Quipito (507m), o Chimbungo (840m), o maior de todos, com ocorrências de hematite em bandas, constituindo verdadeiros itabiritos, e outros. Mais para sul, em arco de concavidade voltada para ocidente, estão os elementos da crista de Corungo (605m a norte e $497 \mathrm{~m}$ a sul). Põem-nos vários problemas, dos quais sublinhamos três, de forma muito sintética: o da extensão, para ocidente, das formações quartzíticas sobre as rochas migmatíticas e as do complexo granítico (Precâmbrico), e que continuam, amplamente, para oriente do Engelo; o do seu desmantelamento, ficando algumas ilhas, mas com altitudes muito mais baixas que as da crista do Engelo; e o comportamento dos quartzitos nos processos complexos da génese e evolução da extensa linha regional N-S de escarpas, contra as quais terminam as superfícies aplanadas da orla litoral.

A oriente da serra do Engelo os quartzitos afloram numa mancha vasta, dando, por um lado, superfícies aplanadas da ordem dos 1 100-1 200m de altitude e, por outro lado, cristas que as dominam. Ainda mais para oriente, formam uma parte da Montanha Marginal, com maciços de mais de $2000 \mathrm{~m}$ de altitude, como é o caso de Uassamba (2 082m).

\section{DA SERRA DO ENGELO AOS MACIÇOS DA MONTANHA MARGINAL}

Segundo as folhas da carta geológica da região, na escala de 1:100 000, e as respectivas notícias explicativas (em fim de texto, referências cartográficas e bibliográficas), a serra do Engelo, que já caracterizamos topograficamente, é "constituída por rochas de natureza quartzítica que assentam em discordância sobre gnaisses e granitos porfiróides". As bancadas ora inclinam para sudoeste, ora para oeste, daí a sua dissimetria, e na base da serra, no contacto dos quartzitos com os granitos, "observam-se fenómenos de granitização em rochas de provável origem arenosa ou pelito-arenosa". As escombreiras são formadas por blocos angulosos de quartzito e de outras rochas, muitos deles de grandes dimensões. Por entre eles aflora, nalguns casos, o granito porfiróide biotítico ou o gnaisse. Uma falha NNE-SSW que, não cortando a crista exactamente ao meio, passa pelas suas extremidades e, um pouco a montante da vertente ocidental, está assinalada pelo alinhamento de nascentes termais.

Entre a serra do Engelo, com os seus 1680 a 1420m de altitude, e os maciços da Montanha Marginal, de mais de $2000 \mathrm{~m}$, distantes para oriente em cerca de $60 \mathrm{~km}$ ou mais em linha recta, estende-se uma vasta área em que, dentro dos limites da bacia do Cambongo, predominam as rochas graníticas e granodioríticas, biotíticas porfiróides, seguidas, a norte e a leste, de quartzíticas e pórfi- 
ros granitóides, e a sueste do complexo granítico-migmatítico (fig. 2). É preciso acrescentar que, na maior parte dos casos, essas rochas estão encobertas por rególitos de espessuras variadas, de que faremos uma breve referência na parte final do texto.

As observações no terreno, os exames atentos da cartografia topográfica e da fotografia aérea estereoscópica revelam, à saciedade, os desenhos geométricos de elementos da rede hidrográfica, com predomínio dos traçados quadriculados ligados a tramas longos e quase rectilíneos, quer do grande colector, o Cambongo-Negunza, quer dos elementos principais das bacias afluentes, sobretudo nas rochas graníticas e afins (figs 2 e 7). Traduzem a acomodação dos cursos de água, grandes e pequenos, permanentes e temporários, a planos e faixas de fraqueza nas rochas cristalinas, criados por fenómenos tectónicos, sob as formas de fracturas (descontinuidades sem deslocamentos de blocos adjacentes) e falhas (com deslocamentos verticais ou horizontais de blocos adjacentes).

Se na folha da carta geológica contendo a serra do Engelo e uma boa parte da bacia do Cambongo (folha de Vila Nova do Seles-Uku) apenas foram desenhadas as falhas prováveis, na que lhe fica ao sul (do Gungo), porém, são numerosas as representações de falhas observadas, tendo as mais importantes a direcção nítida de NW-SE, quase rectilíneas e paralelas, algumas delas alongadas por várias dezenas de quilómetros, sublinhadas por rios que a elas se acomodaram, como o Cubal-Quicombo (falha de mais de $50 \mathrm{~km}$ ) e os seu afluentes Cunenga, Gulungo e Caema, e outros. A sul desse conjunto, duas grandes falhas paralelas, com a direcção $\mathrm{W}-\mathrm{E}$, aprisionaram vários cursos de água, como o Evale e o Cuquendo. E ainda há as falhas mais pequenas, normais e quase nor-

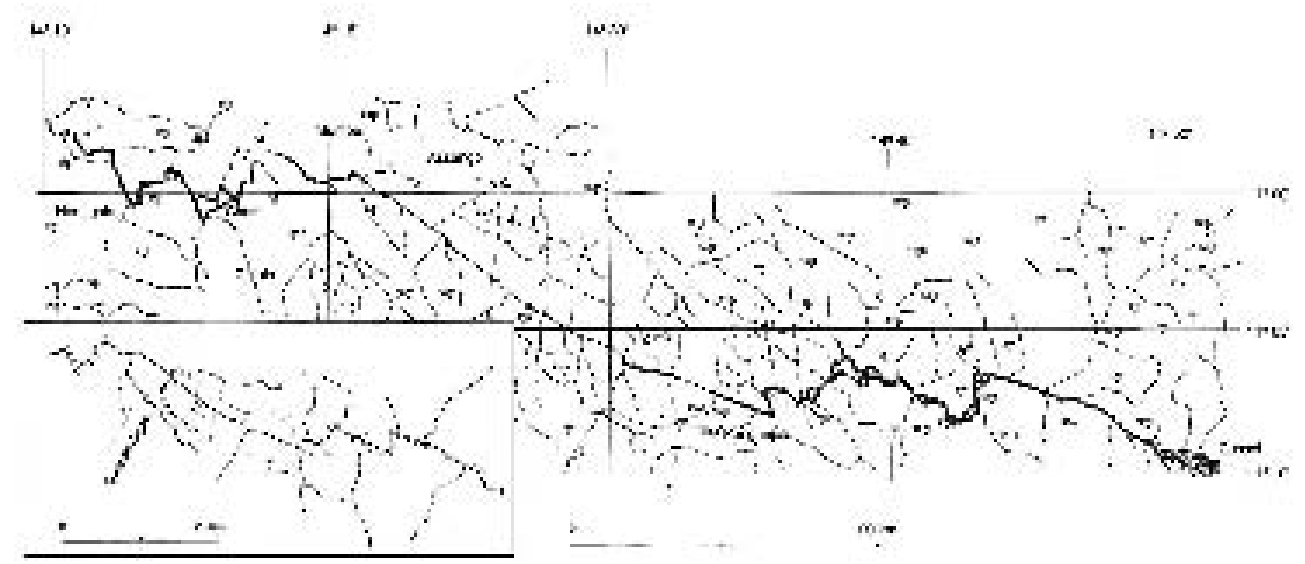

Fig. 6 - O traçado do rio Cuvo ou Queve entre Cussoi e Heangala e de alguns afluentes, reveladores de fracturas e falhas (estas a tracejado na figura do canto inferior esquerdo).

Fig. 6 - The course of the Cuvo or Queve river between Cussoi and Heangala, as well as of some of its tributaries, which indicate the existence of rifts and faults (indicated by a broken line in the lower left-hand side of the figure). 
mais (N-S, NNW-SSE, NNE-SSW) a essas duas grandes direcções. A densidade e a quadrícula de falhas são muito mais evidentes nas áreas de rochas graníticas, quer as porfiróides, quer as de grão fino a médio, do que, por exemplo, no complexo gnáissico-migmatítico-granítico sobre o qual assentam, e que lhe fica a ocidente.

Recorremos a uma área exterior à da bacia do Cambongo-Negunza, mas muito próxima dela, na bacia do Cuvo ou Queve, porque constitui um bom exemplo para ilustrar, por um lado, a presença de quadrículas de fracturas e falhas com algumas direcções predominantes e mais importantes que marcaram, indelevelmente, os traçados de muitos elementos das redes hidrográficas (fig. 6); e, por outro lado, para recordar a envergadura e os importantes efeitos quebradiços de acções tectónicas gerais em Angola, manifestadas em várias épocas geológicas, com rejuvenescimentos em tempos posteriores.

Posto isto, regressemos à do Cambongo-Negunza, na área que vai da serra do Engelo aos maciços da Montanha Marginal, descrevendo, com algum pormenor, a sua geologia (fig. 2). Como já referimos, as rochas graníticas e afins ocupam uma parte importante, que se prolonga para sul dos limites da bacia. O norte desta, na sua separação das cabeceiras de afluentes da margem esquerda do rio Cuvo-Queve, demarca-se numa faixa oeste-este de quartzitos do mesmo tipo dos da serra do Engelo que, mais para oriente, deixa aparecer alguns afloramentos de rochas graníticas, no contacto com os pórfiros granitóides de parte da Montanha Marginal. Os quartzitos são rochas de cor clara, por vezes acinzentada ou rosada, geralmente de grão fino, mais ou menos ricas em materiais pelíticos. O quartzo é, praticamente, o único constituinte, acompanhado de moscovite, por vezes abundante; menos frequentes são os óxidos negros de ferro, a microclina, a albite e o zircão.

Do lado ocidental a faixa quartzítica está separada da serra do Engelo por terrenos do complexo granítico-granodiorítico-gnáissico e tem, no seu interior, o maciço grauváquico de Capanga-Tanhere, ovalóide e abaulado, com cerca de $10 \mathrm{~km}$ NW-SE por 4-5km NE-SW; os pontos mais altos, no sentido NW-SE, vão de $1510 \mathrm{~m}$ a oeste da primeira localidade a $1645 \mathrm{~m}$ na segunda, o que lhe dá um domínio de cerca de 200-300m sobre a topografia circundante. É constituído por rochas cinzentas-negras, de fina granularidade que, juntamente com a recristalização siliciosa ou feldspática da matriz, talvez em íntima relação com os quartzitos granitizados subjacentes, lhe dá forte compacidade. Densas cabeleiras de cursos de água, umas da bacia-afluente do Uiri, outros do Sanjoa, que acabam por entroncar no Cambongo, chanfraram-lhe as vertentes meridionais.

O Sanjoa adaptou-se, nitidamente, a uma fractura em baioneta, revelandose, em grande parte, uma falha evidente desde Candiamba ao sul a Tanhere ao norte, e que pode ser seguida para lá do maciço grauváquico (figs 1 e 7). O interessante é que, para oriente do Sanjoa, a superfície topográfica na base do maciço grauváquico, talhada nos quartzitos, é muito regular, sem relevos residuais, inclinada para sul, desde a curva de nível de $1250 \mathrm{~m}$ a $1120-1130 \mathrm{~m}$, sobre a qual correm, com o mesmo declive, cursos de água quase paralelos, 


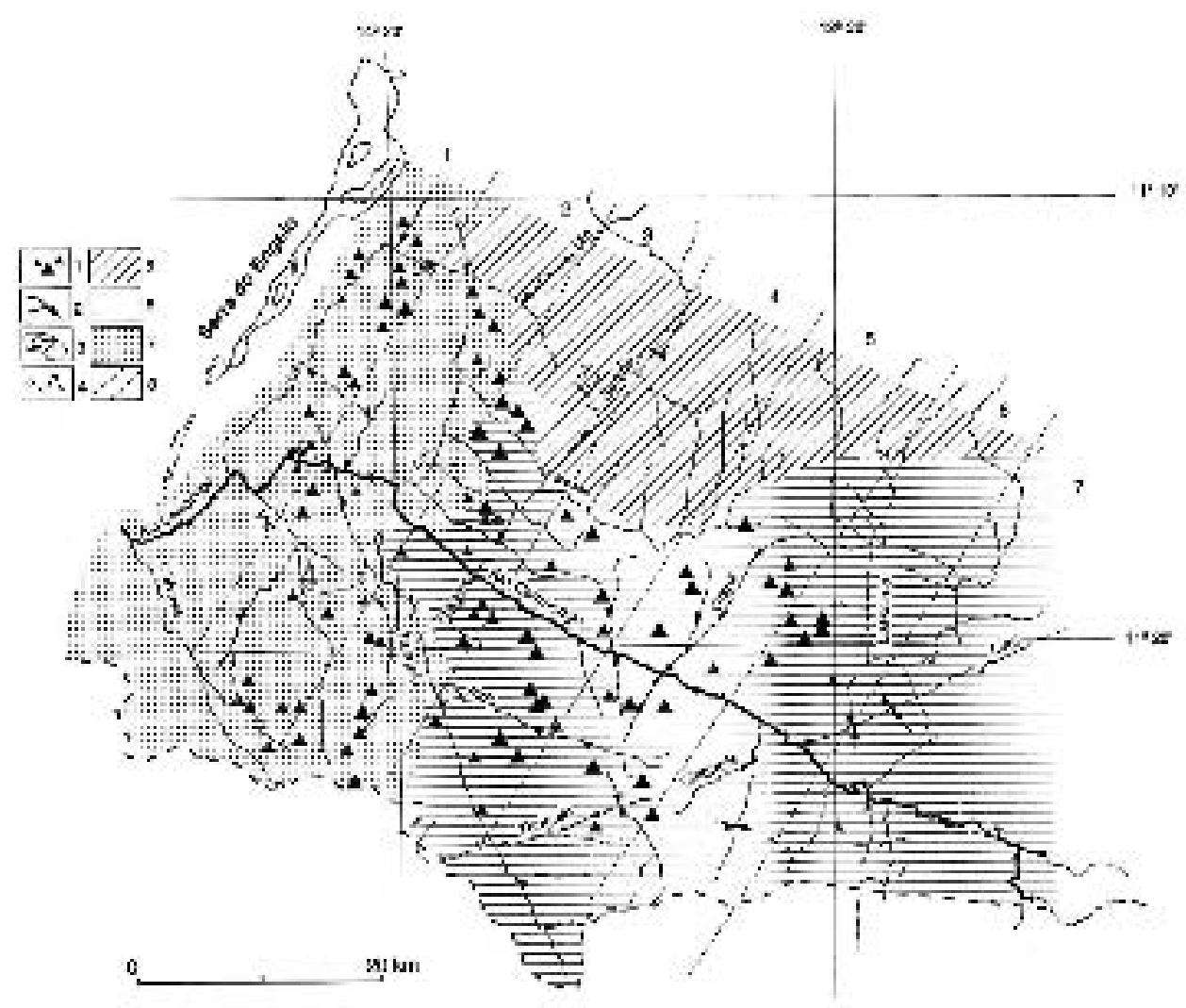

Fig. 7 - Inselberg ou montes-ilhas e vales de fractura a leste da serra do Engelo.

Fig. 7 -Inselbergs or island mountains, and rift valleys to the east of Engelo mountain.

ramos do Ipembe, que é afluente da margem esquerda do Sanjoa. O arco de fronteiras oeste-sul entre os quartzitos e as rochas graníticas é sublinhado pela existência de grupos de montes-ilhas nestas últimas, de que mencionamos, pela mesma ordem e a título de exemplos, a espécie de colar formado por Embi (1 036m), Segunda (1 360m), Londa (1 415m), Chicauila (1 555m), Quipeio (1 240m), Jundo (1 290m), Sulu (1 222m). Reservamos a apresentação dos montes-ilhas para outro local.

$\mathrm{Na}$ parte oriental, a mancha quartzítica, antes do contacto com os pórfiros granitóides da Montanha Marginal, ramifica-se, deixando aparecer afloramentos de rochas graníticas (granitos e granodioritos) que lhes estão subjacentes. Nos limites de nordeste da bacia do Cambongo-Negunza os quartzitos evidenciam-se como cristas alinhadas NW-SE sobre plainos das mesmas rochas (1 100-1200 m de altitude), continuados para sul em rochas graníticas. Naquelas cristas as bancadas estão bastante inclinadas, por vezes quase verticais, em regra geral desmanteladas, das quais mencionamos alguns exemplos, com as altitudes máximas: Dumba-Caíto (1 554m), Luaumbi (1 810m), Queta (1 635m) e, 
um pouco mais ao norte delas, Uassamba $(2082 \mathrm{~m})$, a maior de todas, fazendo parte da Montanha Marginal (fig. 2).

Se algumas das cabeceiras de bacias-afluentes da parte nordeste do Cambongo-Negunza estão em maciços quartzíticos daquela Montanha outras, como as de leste, estão na faixa N-S de pórfiros granitóides, em geral recristalizados, devido, sobretudo, a influências térmicas, e em alguns casos também a acções dinâmicas. Corresponde esta formação, cortada por algumas falhas e fracturas NW-SE, quase paralelas, a uma área de grandes altitudes, como Laúnha (2 184m) e Golungo (2 287m), que continuam para sul com Quimbumba (2 279m) e Gonga (2 315m), já em terrenos do complexo gnáissico-migmatítico-granítico, predominando os migmatitos, de fácies muito semelhante à dos granitos biotíticos de grão médio a fino, onde o Cambongo-Negunza tem as suas nascentes, um pouco a nordeste da povoação de Candiata. Neste troço inicial o rio está adaptado a uma falha NW-SE, paralela a outras localizadas mais a norte, no mesmo complexo, que foram aproveitadas pelos seus afluentes, como o Cavele e o Luambimbe.

A passagem dos pórfiros para aquele complexo é feita de um modo quase imperceptível, por virtude da granitização e diferenciação sofridas pelos primeiros. São rochas constituídas por uma matriz microgranular acinzentada, onde se destacam fenocristais de plagioclase e de quartzo (anédricos e muitos corroídos), umas vezes de composição granodiorítica e outras granítica, rica em feldspatos potássicos. Encostada a ocidente da mancha de pórfiros granitóides mencionamos uma de quartzitos granitizados, de grão fino, alternando com quartzitos francos, micaxistos e migmatitos incipientes, em que o quartzo é o constituinte dominante, contendo ainda moscovite, óxidos de ferro disseminados ou em leitos, microclina, albite, microclina sódica e biotite. $\mathrm{O}$ afloramento também tem desenvolvimento norte-sul, com largura mais ampla ao norte, na área de Apato (altitudes de 1 100-1 200m), ao sul da qual se encontra o ponto mais elevado, Mambo (1 360m), seguido de Chicobolo (1 218m).

A sul deles há duas pequenas falhas oeste-este, quase paralelas. A primeira marca, linearmente, o contacto entre bancadas de quartzitos granitizados inclinadas para sul e os granitos e granodioritos biotíticos porfiróides, e a segunda rasa o limite setentrional de uma pequena mancha dos primeiros no meio dos segundos. O Cambongo-Negunza passa entre as duas falhas, depois de ter atravessado a parte meridional, mais estreita (cerca de $3 \mathrm{~km}$ ), da mancha quartzítica. A norte de Mambo, outra falha, NE-SW, atravessa aquelas duas formações.

\section{OS VALES DE FRACTURA E OS RELEVOS RESIDUAIS DO TIPO INSELBERG}

É nas rochas graníticas que os vales de fractura e os relevos do tipo inselberg ou monte-ilha ganham maiores expressões, os primeiros exuberantemente evidenciados pelos traçados dos cursos de água. As figuras representando ele- 
mentos fluviais seleccionados e decalcados das folhas da carta topográfica de 1:100 000, com o apoio da fotografia aérea estereoscópica, espelham bem a importância das fracturas e falhas, abundantes em todo o território da bacia do Cambongo-Negunza. Contudo, é naquelas rochas que são mais notáveis os cruzamentos de fracturas em quadrículas de padrões variados, que os cursos de água, adaptando-se a elas, tornaram mais evidentes. O longo alinhamento NESW de fracturas, de cerca de $25 \mathrm{~km}$, aproveitadas pelos rios Luai, cujas águas correm de nordeste para sudoeste, Chiquela, em sentido oposto, e Sanga-Tangaio, no percurso NE-SW, marca, de certo modo, um limite para sul do qual se desvanecem os padrões quadriculares (fig. 7).

Antes de abordarmos essas matérias faremos uma síntese da geologia das rochas graníticas e afins que, na bacia do Cambongo-Negunza, para oriente da crista quartzítica do Engelo, afloram em área vasta, nas mais das vezes encobertas por rególitos espessos. Ainda segundo as folhas da carta geológica e as respectivas notícias, trata-se de um complexo de granitos, granitos monzoníticos, granodioritos e granitos gnaissóides que, no terreno, nem sempre são fáceis de distinguir. São rochas biotíticas, com tonalidades acinzentadas, nuns casos de grão grosseiro a porfiróide e noutros de grão fino a médio, sendo estas mais compactas, constituídas, essencialmente, por feldspatos, quartzo e biotite.

Entre os primeiros, a parte dominante é a da microclina, a que se juntam a oligoclase-albite em vias de microlinização e a anortoclase. As plagioclases estão fragmentadas, substituídas por lamelas moscovíticas e grãos de epídoto, alinhados segundo o estiramento, ou corroídos; e nos casos em que ficaram bem conservados têm composição oligoclásica. Todos eles apresentam os mesmos tipos de inclusões delatoras de metassomatismo potássico e pronunciado diaclasamento. Nas rochas de grão grosseiro os fenocristais cinzento-acastanhados de microclina chegam a ser bastante grandes, por vezes com dimensões de 5$-6 \mathrm{~cm}$, rodeados por plagioclases raramente frescas, albitizadas e esverdeadas, estando as cálcicas marginalmente corroídas e com substituição potássica. Aqueles fenocristais, postos em relevo pelos agentes de meteorização, acabam por tomar formas arredondadas e resistem, de modo satisfatório, à desagregação. Todavia, em regra geral, estão fracturados e com ligeira caulinização. Os cristais de quartzo, vitroso ou opalescente e azulado, com extinção fortemente ondulante, na maioria dos casos mostram-se fragmentados, contendo numerosas inclusões pontuais e acículas de rútilo, estando rodeados por agregados microcristalinos resultantes do esmagamento e consequente recristalização. A biotite, de cor esverdeada, é abundante, quase sempre orientada, em folhas desenvolvidas, encurvadas ou fendidas, ou em agregados lamelares finos. As rochas ainda têm, como constituintes acessórios, esfena, em cristais desenvolvidos e abundantes, apatite, zircão, alanite e grãos de minerais de ferro alterados em goetite; e, como secundários, epídoto e sericite.

Do conjunto destas informações, muitas delas obtidas do exame de lâminas delgadas das rochas, segundo os geólogos que trabalharam na área, ressalta a importância dos esforços tectónicos, mais intensos para ocidente: extinções 
ondulantes, sobretudo no quartzo, plagioclase e mica, maclas de plagioclase encurvadas ou interrompidas, desenvolvimento de produtos secundários de recristalização, microfracturas, estiramentos, alinhamento de constituintes, etc. Parece ter carácter geral a direcção de fracturação $\mathrm{N} 20^{\circ} \mathrm{E}$, pois grande parte dos filões de quartzo apresentam essa mesma, sucedendo de igual modo com as camadas de migmatitos e a lineação dos gnaisses que afloram a noroeste da Serra do Engelo. Segundo os geólogos que estudaram a área, os granitos não apresentam contactos próprios de corpos intrusivos, nem auréolas de metamorfismo de contacto. Tudo faz crer em corpos metassomáticos individualizados. São conhecimentos de valores inestimáveis para o estudo da génese e evolução de certas formas do relevo, como os inselberge ou montes-ilhas.

1. Sublinhemos, de novo, que o território da bacia do Cambongo-Negunza reúne muitos testemunhos visíveis de ter sido submetido, por várias vezes, a acções tectónicas importantes, das quais resultou intensa fracturação das rochas. São demasiado evidentes dois sistemas de fracturas mais ou menos paralelos, um com direcção dominante NNW-SSE e outro que lhe é, aproximadamente, normal. Ambos os sistemas impuseram aos actuais cursos de água troços rectilíneos e o cruzamento de fracturas favoreceu desenhos em quadrícula, mais ou menos regulares (figs 2 e 7). Além dessas direcções regionais há outras definidas, com certa frequência, por alinhamentos e orientação de fracturas e diaclases.

Desde há muito tempo os geógrafos têm utilizado esquemas operacionais para a qualificação de vales de fractura (Feio e Brito, 1950; Feio, 1981), de que recordamos uns tantos relacionados com exemplos observáveis, sobretudo, numa área a leste da Serra do Engelo. Outros fomos buscá-los fora da bacia do Cambongo-Negunza, às dos rios Cuvo-Queve, que lhe fica ao norte, e CubalQuicombo e mais alguns, ao sul.

Os cursos de água tendem a instalar-se em fracturas e falhas, pois ao longo delas a erosão fluvial fica mais facilitada. Quando assim sucede desenvolvemse mais rapidamente que outros, dado que podem aumentar a velocidade de encaixe e a capacidade de captação de linhas de água vizinhas, ganhando maior importância como colectores. Deste modo, as fracturas e falhas são postas em evidência e o conjunto de vales aí desenvolvidos constitui um inventário de inestimável valor, sobretudo nas rochas duras, como granitos e outras comparáveis, onde as formas se conservam mais nítidas. Recordamos os longos traçados, aproximadamente rectilíneos ou em curvas suaves, de troços dos rios Cuvo-Queve, Cambongo-Negunza, Lua, Cunenga, Gulungo, Cubal-Quicombo, todos eles com a orientação NW-SE, acomodados em falhas importantes, caracterizadas por certo paralelismo, que cortam rochas graníticas porfiróides.

Restringindo-nos a uma área da bacia do Cambongo-Negunza em rochas graníticas, a figura 7, composta a partir de folhas da carta topográfica de Angola na escala de 1:100 000, oferece exemplos de alguns dos critérios mais utilizados pelos geógrafos. Começamos pela existência de troços longos e quase rectilíneos, 
como os do Cambongo e dos seus afluentes Tangaio e Sanjoa, e o prolongamento desse traçado por um afluente de colector importante, notável no ponto em que o Cambongo muda, bruscamente, de S-N para E-W (canto sueste da figura); o afluente aí representado tem o mesmo alinhamento de troços de outros afluentes do Cambongo que descem na vertente vigorosa da Montanha Marginal.

A mudança brusca de traçado, em ângulo recto, é reveladora do cruzamento de fracturas, como mostra, amplamente, o rio Tangaio, e também se verifica no percurso do Cambongo, na extremidade sueste da figura. Por vezes conjugamse ângulos rectos de lados curtos, dando o chamado traçado em baioneta, como sucede na bacia superior do Sanjoa, na extremidade norte de uma falha provável, com desligamento, que é paralela à da serra do Engelo, e se pode marcar desde o curso do Tangaio, a sul, mas normal a este, até ao maciço grauváquico de Capanga-Tanhere, e mesmo para lá dele. Dois pequenos afluentes do Cambongo, que corre em sentidos opostos, têm o mesmo alinhamento.

Nessa área central da figura 7 evidencia-se outro modo de reconhecimento de vales de fractura, com base na malha quadriculada do traçado de cursos de água. É notável a imagem de conjuntos de linhas paralelas de curtas distâncias que se entrecruzam, tal como sucede em redes de pequenas fracturas ligadas a outras maiores. Mas o critério do paralelismo deve ser aplicado com reservas quando se trata de pequenos afluentes, pois essa configuração pode estar antes ligada à acomodação com a superfície topográfica, como sucede relativamente aos afluentes do Ipembe, numa superfície muito regularizada, nos quartzitos sobre os quais assentam os grauvaques de Capanga-Tanhere, inclinada de norte para sul.

Outro critério utilizado baseia-se no reconhecimento de haver dois ou mais cursos de água alinhados mas que correm em sentidos opostos, como bem exemplificam o troço quase E-W do Tangaio, o Chiquela, que vai de sudoeste para nordeste e o Luai, que flui no sentido contrário. Acresce a isto o facto destes dois afluentes, das margens esquerda e direita do Cambongo, que corre em sentidos opostos, convergirem num mesmo sítio.

Uma parte desses critérios coincide com o traçado de falhas designadas como prováveis nas folhas da carta geológica de Angola, na escala de 1:100 000, contendo a bacia do Cambongo. Serve de exemplo a série de fracturas aproveitadas pelos rios Indo, afluente do Tangaio, Chiquela e Luai, em que o traçado geral é o de um arco, cuja terminação oriental, em segmento bem linear e longo, marcado como falha observada, se prolonga pelos quartzitos granitizados da área de Apato. E é interessante referir que o arco tem um certo paralelismo com o do contacto entre os quartzitos e as rochas graníticas, desde a fractura (ou falha provável) do rio Sanjoa, prolongada até ao Tangaio, a ocidente, e a que passa perto da Quivemba, a oriente, aproveitada, em grande parte, pelo Luassimo. A distância entre os dois arcos é de cerca de $10 \mathrm{~km}$.

Há ainda os critérios baseados nos traçados em zigue-zague e em grega, pouco evidentes na bacia do Cambongo-Negunza, mas abundantes e esplendorosos na do Cuvo-Queve. Bons exemplos estão na área de Hongo-Cafula (altitudes entre cerca de 1250 e $1300 \mathrm{~m}$ ), logo a montante da Montanha Marginal, 
que o rio desce por um troço rectilíneo, desde Panganjala para oeste-noroeste. Esta é a direcção geral do Cuvo-Queve, que reproduz uma das direcções tectónicas fundamentais da faixa ocidental de Angola.

Já agora, recuemos algumas dezenas de quilómetros, à área de Quissabi-Quiungo, no extremo direito da figura, para ter uma sucessão de imagens que traduzem as complexidades da rede hidrográfica. Primeiramente, pode-se ver um troço do Cuvo-Queve meandrado na sua planície aluvial, com arcos de meandros abandonados, recebendo, pela margem direita, o Cussoi e, pela esquerda, o Cassolobir; o vale é largo, passando-se da ampla planície aluvial, onde as altitudes são de cerca de $1246 \mathrm{~m}$, para rampas ou planos inclinados, forrados de mantos de meteorização, que sobem, suavemente, até aos $1340-1350 \mathrm{~m}$. A amplidão dessas rampas é interrompida, bruscamente, onde se erguem relevos vigorosos, como sucede com os maciços de Quimanga (2 023m), Quipungo (1 $897 \mathrm{~m})$ e Gonga (2 095m) a sul do rio Cuvo-Queve.

A partir de Bumba o rio tem um troço quase rectilíneo, com alguns arcos suaves, onde a planície aluvial se afila, e recebe a meio, na margem direita, o Tunga. A partir do local da margem direita onde entram o Cazanga e o Calamba, o curso do Cuvo-Queve muda, em ângulo recto, da direcção geral SE-NW para um troço N-S de cerca de $3 \mathrm{~km}$, com sectores de leito de grande largura e ilhotas no meio. A norte de Quipungo volta a readquirir aquela direcção, mas num traçado muito mais complicado que os anteriores: em grega simples, depois em zigue-zague e, novamente, em grega até Panganjala, onde, por meio de uma curvatura apertada, começa a descer a Montanha Marginal, fortemente encaixado num vale de traçado bastante rectilíneo, de SE para NW. Antes disso, por volta da latitude de $11^{\circ} 06^{\prime}$ e entre as longitudes de $14^{\circ} 37^{\prime}$ e $14^{\circ} 40^{\prime}$, a sul de Cuhá (1 511m)-Bango (1 441m)-Jambo (1 462m), o rio desdobra-se em braços que rodeiam ilhotas.

Vários testemunhos atestam como os factores tectónicos foram determinantes na intensidade do encaixe. Entre eles, certamente que o rejogo da falha, que o rio aproveitou, teve importância fundamental. Assim mostra o facto dos talvegues e leitos de muitos afluentes terem ficado suspensos, ou seja, desnivelados em relação aos do colector principal, incapazes de o acompanharem com a mesma velocidade erosiva. O traçado rectilíneo, apesar de ligeiros desvios, continua por mais de $30 \mathrm{~km}$, desde a Montanha Marginal à linha de escarpas que marcam a passagem para as superfícies litorais, com cerca de $300 \mathrm{~m}$ de altitude no sopé daquelas. Nessa descida o Cuvo-Queve volta a ter grande complexidade de traçados até à foz.

Outro assunto que nos interessou, ao analisarmos as complexidades das redes hidrográficas, onde são nítidas as influências de fenómenos tectónicos, foi o das capturas fluviais. Todavia, apenas houve tempo para algumas observações gerais, que continuam carecidas de aprofundamento. Por isso mesmo limitamo-nos a mencionar um único exemplo, o caso do encontro do Cambongo-Negunza com o seu afluente Uiri, no campo de pequenas fracturas paralelas logo a sueste da parte meridional da crista do Engelo. 
Tudo leva a crer que na área delimitada pelos povoados de Uango e Cabinda $(830 \mathrm{~m})$ e pelo Chiouco $(1 \mathrm{135 \textrm {m }})$, um ramo da margem direita do Val, que é hoje afluente da margem esquerda do Cambongo, foi capaz de captar as águas deste, pelo aproveitamento de uma falha SW-NE, onde pode desenvolver erosão regressiva veloz. O Cambongo que, desde o Quitongo até à Ganja, percorria um longo troço de vale largo, com leito aluvionar à cota de cerca de $900 \mathrm{~m}$, no sentido SE-NW, por alturas do Chiouco encaixou-se abaixo de $850 \mathrm{~m}$ e passou a correr num tramo NE-SW até ao Val. A captura fez com que as águas se juntassem, tomando o Cambongo a direcção SE-NW, paralela ao do seu curso no longo troço quase rectilíneo, mas mais a sul, e logo depois NE-SW, onde recebe o seu afluente Uiri, cujo percurso NE-SW segue de perto o sopé da Serra do Engelo. No conjunto, o Cambongo desenvolve um traçado em baioneta entre o Chiouco e a confluência do Uiri.

Ora bem, olhando o traçado da rede nessa pequena área e as condições topográficas, juntamente com a posição de alguns depósitos, tudo leva a crer que seria mais lógico que o Cambongo, depois do Chiouco, tivesse prosseguido para noroeste, que era, afinal, a sua direcção dominante desde a entrada nos terrenos graníticos confinantes com os da Montanha Marginal, e recebesse o Uiri na baixada aluvionada do Uango, sem a necessidade de se meter na complicação do traçado em baioneta, só justificável pelos dispositivos tectónicos e pela força erosiva adquirida por um pequeno ramo lateral do Val.

2. Finalizaremos esta parte com algumas notas sobre os relevos do tipo inselberg ou monte-ilha em rochas graníticas. Voltamos a concentrar a nossa atenção nos afloramentos destas rochas que rodeiam a crista quartzítica do Engelo e se prolongam, vastamente, para sul e oriente. Deste lado e a norte estão limitados por extensos afloramentos de rochas quartzíticas, quartzitos e quartzitos granitizados; e a ocidente por uma faixa do complexo migmatítico. Note-se que neste quase não há montes-ilhas, ao contrário da mancha gnáissica-migmatítica-granítica da bacia superior do Cambongo-Negunza, onde eles são abundantes, isolados ou em grupos (figs 2, 3 e 4).

As características geológicas já foram apresentadas, com base em documentos existentes e observações de campo. Resta-nos aqui sublinhar que, em regra geral, salvo nas partes mais declivosas, as rochas estão encobertas por rególitos ou mantos detríticos de espessuras variadas. Afloram nos plainos ou superfícies topográficas de fraco declive quando aqueles são destruídos pelos agentes erosivos; estão visíveis nas barreiras naturais, nas vertentes abruptas dos montes-ilhas e dos vales encaixados Em vários locais, no interior dos mantos detríticos de cobertura desenvolveram-se níveis de lateritização ou bauxitização que, uma vez expostos à circulação do ar, por destruição dos materiais que se dispunham sobre eles, puderam encouraçar, dando as célebres couraças ferruginosas ou aluminosas. As mais antigas serão datáveis do Terciário médio. Passada a linha de escarpas litorais, o clima entre a Serra do Engelo e os maciços da Montanha Marginal tende a ser húmido e sub-húmido chuvoso, com 
totais anuais de precipitação entre 800 e $1100 \mathrm{~mm}$ e valores máximos em Março $(560 \mathrm{~mm})$ e Dezembro $(259 \mathrm{~mm})$. O coberto vegetal é formado por bosques e savanas de árvores baixas, arbustos e capins altos.

É interessante notar que a maioria dos montes-ilhas da bacia do Cambongo-Negunza aparece numa faixa NW-SE, de cerca de $15 \mathrm{~km}$ de largura, com o rio a meio, que tem uma orientação normal à da serra do Engelo. No pequeno patamar granítico que a ocidente antecede a crista quartzítica elevam-se, fora dos limites setentrionais da bacia do Cambongo-Negunza, de ocidente para oriente e de norte para sul, numa primeira linha, os de menor altitude, como Cabange $(558 \mathrm{~m})$, Locundo $(535 \mathrm{~m})$ e Capir $(595 \mathrm{~m})$; depois, em segunda linha, os mais altos, como Bombo (810m), Quenguir (890m), Quinjembo (930m); e um pouco mais a oriente do Quenguir, Dandiange (cerca de $900 \mathrm{~m}$ ). Estas diferenças altimétricas concordam, em certa medida, com o declive para noroeste e oeste do patamar granítico, desde os $1000 \mathrm{~m}$ na base do Engelo aos $750 \mathrm{~m}$ no rebordo do degrau, nem sempre abrupto, mas mais em declive quase regular, de passagem para as superfícies de $300 \mathrm{~m}$ modeladas no complexo migmatítico. Cabange pode ser considerado um relevo residual deixado nessa posição por recuo daquele degrau, enquanto Locundo e Capir, na ponta de um esporão do mesmo, estarão em fase de destacamento.

Passando para leste da crista quartzítica do Engelo, na tal faixa de rochas graníticas de cerca de $15 \mathrm{~km}$ de largura, medida de nordeste para sudoeste, atravessada de sueste para noroeste pelo Cambongo-Negunza, aparece um sem número de relevos do tipo inselberg ou monte-ilha (figs 4, 5 e 7). Primeiramente é notável a existência de uma série deles numa orla de contacto em arco entre as rochas graníticas a sul e as rochas quartzíticas a norte, não havendo qualquer degrau ou desnível assinalável entre as duas formações rochosas. Assim, aparecem, desde as proximidades da parte setentrional da crista, os seguintes montes-ilhas, com as respectivas altitudes e também dos plainos que dominam: um, sem nome $(1065 \mathrm{~m})$, Ilemba $(1035 \mathrm{~m})$ e Lobango $(1160 \mathrm{~m})$, na margem direita do rio Uiri (cerca de 950m); Quiloro (1 030m), Cariangue (1 180m) e Góiu (1 140m), no interflúvio (um pouco mais de $1000 \mathrm{~m}$ ) entre o Carília, afluente do Engiva-Uiri, e o Lai, afluente do Unjoa-Sanjoa; Embi (1 036m), Segunda (1360m), Londa (1415m) e Chicauíla (1 555m), no interflúvio (1 000-1 060m) entre o Carília, e afluentes do Lai e do Sanjoa; Cunjo (1 188m), Quipeio (1 240m) e Atrovera (1 227m), na margem esquerda do Ipembe (cerca de $1000 \mathrm{~m}$ ); Jundu (1 209m), entre o Nandau e o Jundo, ramos da margem esquerda do Acalui (1 $000-1$ 100m), um afluente do Ipembe, e Sulu (1 222m), num interflúvio (1 170-1 180m) um pouco mais a oriente.

Para sul destes montes-ilhas, dispostos na faixa encurvada da fronteira entre as rochas graníticas e as quartzíticas, existe uma multidão deles dispersos no terreno, sem que, por vezes, não deixe de haver alguns alinhamentos, impostos, certamente, pelas redes de fracturas e falhas. Vejamos um ou dois exemplos. O mais volumoso e elevado de todos, Oco (1575m), acompanhado de um relevo muito mais pequeno a noroeste, fica a SSW do grupo já referido de 
Segunda-Londa-Chicauíla. Do seu lado ocidental, aparece um alinhamento formado por Ponguire $(1065 \mathrm{~m})$, Camata $(1160$ e $1235 \mathrm{~m})$ e Itumbo $(1160 \mathrm{~m})$. Comandam um retalho de superfície cuja altitude ronda os $1000-1050 \mathrm{~m}$. Ora bem, os três agrupamentos, com nítida orientação geral de NW-SE, estão enquadrados por um conjunto de pequenas fracturas paralelas, normais às duas maiores (registadas como falhas prováveis) aproveitadas pelo rio Lai, afluente do Sanjoa, e por este próprio. Não admira até - por ora simples hipótese - que o enorme volume de rocha exposta no Oco, de cerca de $500 \mathrm{~m}$ acima do retalho de superfície que rodeia o conjunto de que faz parte, se possa dever a levantamento da espécie de tecla da qual se eleva. A sua altitude máxima é superior à de muitos pontos altos da serra do Engelo e não está muito longe de um dos máximo (1 629m) dessa crista cujas bancadas, quartzíticas, bastante inclinadas, assentam nos granitos: uma diferença altimétrica de cerca de $50 \mathrm{~m}$. O mesmo se pode dizer do Chicauíla ( $1555 \mathrm{~m})$, com menor volume de rocha exposta, mas uma altura que se aproxima da do Oco. O Chiongo (1 235m) exemplifica o caso de um monte-ilha assente num pequeno bloco delimitado por fracturas aproveitadas pelo Landa e pelo Bamba, dois afluentes da margem esquerda do Cambongo, e pode dizer-se o mesmo do Langulo $(1380 \mathrm{~m})$, que fica fronteiro, a norte do rio.

Enquanto nos citados, como noutros casos, a distribuição, a orientação e exposições maciças parecem nitidamente ligadas aos padrões de fracturas, também há muitos exemplos de relevos de posição interfluvial, isto é, testemunhos restantes de processos de erosão regressiva e alargamento dos plainos, como exemplificam o Ganja (1020 e $1060 \mathrm{~m})$, num interflúvio (850$900 \mathrm{~m}$ de altitude) entre o Cambongo e o Tangaio, e o grupo Jongo (1 240 m)-Jamba (duas pequenas cúpulas de 1215 e $1250 \mathrm{~m}$ ), no interflúvio (1 100$1150 \mathrm{~m}$ ) entre o Cambongo e o Inde, afluente da margem direita do Tangaio, e muitos outros.

Numa apreciação de conjunto é fácil verificar que, no terreno, a densidade de montes-ilhas é maior para NNW do alinhamento de fracturas aproveitadas pelos rios Luai, Chiquela e parte do Songa-Tangaio ou, dito de outra forma, é maior entre a crista do Engelo e esta linha, o que desafia as teorias de Lester King, especialmente sobre os bornhardts, quanto à formação de relevos residuais em relação com o recuo paralelo de uma escarpa importante, por processos que ele englobou sob a designação de pediplanação (King, 1953 e 1962). Nesta acepção, em condições normais, os volumes e altitudes dos montes-ilhas diminuiriam a partir das proximidades da escarpa, isto é, quanto mais distantes dela, menores deveriam ser as suas dimensões. Como isso não sucede dentro dos limites acima citados do interior da bacia do Cambongo-Negunza, são outros os argumentos a expender.

Nos montes-ilhas da bacia do Cubal da Hanha, afluente do rio Catumbela, no centro-litoral de Angola, e da bacia do Curoca, no deserto de Moçâmedes-Namibe, que estudámos em anos anteriores, desenvolvemos a discussão mantida entre os seguidores da teoria da pediplanação de Lester King e os que se 
mantinham mais perto das concepções em torno da evolução de duas superfícies de aplanação, a topográfica subaérea e a de meteorização profunda, no contacto do rególito com a rocha sã, magistralmente expostas por Julius Büdel, a que juntamos uma proposta aliciante dos processos de etching, feita muitos anos antes por E.J. Wayland (Büdel, 1957; Wayland, 1933). De uma maneira geral, a bacia do Cambongo-Negunza está instalada - salvo a sua parte superior, aberta nos maciços da Montanha Marginal - no que se pode considerar a superfície intermédia de aplanações da faixa atlântica de Angola, correspondendo à Africana da terminologia de L. King, mas os seus montes-ilhas são mais densos no lado ocidental, a caminho da Serra do Engelo, onde o ciclo de erosão está mais avançado, do que nas proximidades do rebordo montanhoso.

Não é fácil estabelecer um diagrama da distribuição dos montes-ilhas, tendo em conta os seus valores altimétricos relacionados com as posições no terreno. Tentamos uma análise aleatória em faixas NE-SW, mais ou menos paralelas ao estiramento da Serra do Engelo e normais à direcção SE-NW do CambongoNegunza, tendo cada uma delas a largura de $5 \mathrm{~km}$ (fig. 7). Sublinhamos, entretanto, o facto das altitudes da crista quartzítica diminuírem de norte $(1680 \mathrm{~m})$ para sul $(980 \mathrm{~m})$ e do rio Cambongo-Negunza contornar a sua ponta meridional, a caminho das superfícies de cerca de $300 \mathrm{~m}$, correndo em terrenos graníticos que a rodeiam. Isto leva a concluir que a crista já constituía uma barreira topográfica quando se instalou a rede do Cambongo-Negunza em função do nível de base geral representado pelo Atlântico, cuja abertura terá tido lugar entre o Jurássico final e o Eocretácico.

Se a leste os plainos interfluviais nos limites da bacia do rio estão a altitudes de 1 150-1 200m, na base da serra do Engelo as cotas são de cerca de $900 \mathrm{~m}$, salvo, naturalmente, os pontos altos de montes-ilhas e outros relevos, superiores a $1000 \mathrm{~m}$. Considerando as faixas acima mencionadas, em número de cinco, desde a serra do Engelo ao alinhamento de fracturas aproveitadas pelos rios Sanga-Tangaio, Chiquela e Luai, e desde o contacto das rochas graníticas com as rochas quartzíticas a norte e os limites da bacia do rio a sul, reunimos no quadro seguinte alguns dados provisórios sobre o número de montesilhas observados, os complexos de rochas graníticas - correspondendo as letras $\mathrm{A}$ e $\mathrm{B}$, respectivamente, ao complexo granítico-granodiorítico-gnáissico e ao complexo granomonzonítico-granodiorítico biotítico porfiróide - e a variabilidade altimétrica dos relevos em questão.

Dos 85 montes-ilhas observados com algum pormenor, podemos acrescentar a sua distribuição em partes iguais pelas manchas dos dois complexos de rochas graníticas e que 39 ficavam ao norte do Cambongo-Negunza e 46 ao sul; a dificuldade do estabelecimento de uma regra de escalonamento altimétrico, ainda que haja, aparentemente, um maior número de montes-ilhas da ordem dos $1200 \mathrm{~m}$ nas faixas 4 e 5, mais afastadas da serra do Engelo e da passagem do Cambongo-Negunza para as superfícies do litoral; a existência de um núcleo de altitudes mais elevadas no extremo setentrional da faixa 3, acima dos $1300 \mathrm{~m}$, culminando no Oco (1 575m), nitidamente ligado a um quadriculado de frac- 
turas e falhas, como referimos noutro local deste artigo; e a importância da rede hidrográfica. Por ora, nada mais podemos dizer acerca do interesse deste exercício, carecido de aprofundamento.

\begin{tabular}{|c|c|c|c|}
\hline Faixa & Observações & Geologia & Variabilidade altimétrica dos montes-ilhas (m) \\
\hline 1 & 12 & A & $\begin{array}{l}4 \text { de } 1000-1100 ; 6 \text { de } 1 \text { 110-1 } 190 \\
2 \text { de } 1210-1220\end{array}$ \\
\hline 2 & 21 & A & 5 de $960-990 ; 8$ de $1010-1080 ; 8$ de 1 100-1 190 \\
\hline \multirow[t]{2}{*}{3} & 8 & A & $\begin{array}{l}2 \text { de } 1 \text { 020-1 040; } 4 \text { de } 1 \text { 160-1 190; } \\
2 \text { de } 1 \text { 200-1 } 220\end{array}$ \\
\hline & 14 & B & $\begin{array}{l}1 \text { de } 970 ; 6 \text { de } 1010-1060 ; 1 \text { de } 1160 ; \\
1 \text { de } 1235 ; 2 \text { de } 1320-1360 ; 1 \text { de } 1405 \text {; } \\
2 \text { de } 1550-1575\end{array}$ \\
\hline 4 & 15 & B & $\begin{array}{l}3 \text { de } 1 \text { 010-1 } 020 ; 3 \text { de } 1 \text { 120-1 } 188 \\
3 \text { de } 1200-1 \quad 205 ; 6 \text { de } 1220-1 \quad 270\end{array}$ \\
\hline 5 & 15 & B & $\begin{array}{l}3 \text { de } 1 \text { 130-1 } 160 ; 9 \text { de } 1205-1252 \text {; } \\
3 \text { de } 1310-1380\end{array}$ \\
\hline
\end{tabular}

\section{BREVES CONSIDERAÇÕES PRELIMINARES PARA UMA EXPLICAÇÃO GEOCRONOLÓGICA DINÂMICA}

A área limitada a oeste pela serra do Engelo e a leste pelos maciços da Montanha Marginal, de topografia rugosa, mas que se reconhece ter estado sujeita à rasoira da erosão, pode considerar-se como resultante não apenas de um ciclo, mas sim de vários, decorridos longamente. Tais processos erosivos, na sua forma mais activa, sobretudo fluviais, a par dos de meteorização profunda em larga escala terão ido até finais da primeira parte do Miocénico. Entretanto, nesses tempos de longa duração, entrosavam-se processos tectónicos regionais e locais, marcados, por um lado, pelo rejogo da flexura litoral, com rejuvenescimento de fracturas e falhas antigas ou criação de outras, e, por outro lado, por alterações climáticas e ambientais com incidências importantes nos processos de meteorização e nos sistemas de drenagem fluvial. É incorrecto procurar uma única explicação, quando é sabido que as formas topográficas resultam de actuações convergentes de processos diferentes.

Tudo leva a crer que a maioria dos futuros montes-ilhas se tenha individualizado criptogenicamente, graças aos progressos da meteorização profunda ao longo de fracturas e falhas abertas dos maciços graníticos precâmbricos. No Miocénico inferior terá havido novos levantamentos, moderados do bordo continental, com inclinação progressiva da área para ocidente e incisão de rios operando a diferentes níveis. O desenvolvimento de um novo sistema de drenagem, com os cursos de água a cortarem os seus vales através de mantos de meteorização, levou-os a ajustarem-se às estruturas. Deste modo, no prosseguimento 
dos processos, os vales principais ficaram entre montes-ilhas incipientes. Nos finais do Pliocénico terá havido outro levantamento com inclinação da orla continental para ocidente, incisão fluvial de gargantas e formação local de superfícies de erosão a níveis mais baixos.

É interessante notar que a maioria dos montes-ilhas modelados nos granitos porfiróides, ricos em feldspatos potássicos, tem formas em cúpula ou domo, de vertentes abruptas desnudadas de vegetação. Na terminologia geomorfológica ganharam a designação de bornhardts, atribuída por vários autores em homenagem ao investigador alemão desse nome, que foi o primeiro a chamar a atenção para as particularidades de tais formas de montes-ilhas (Bornhardt, 1900). Já não são tão frequentes nos granitos de grão fino a médio, nem nos pórfiros granitóides e nos granodioritos, onde se apresentam mais como picos cobertos por vegetação.

Nas cúpulas, não obstante a abundância de biotite, dotada de propriedades expansivas por hidratação, e de feldspatos, alteráveis em argilas ou contribuindo para a arenização (especialmente a plagioclase), as juntas verticais, que nunca são muitas, em regra geral mantêm-se muito fechadas, o que parece indicar, contrariamente ao que muitos investigadores pensavam, que as rochas dos domos estão muito mais sob compressão do que sob descompressão (Twidale, 1973). Por outro lado, as superfícies em cúpula permitem que as águas pluviais escorram rapidamente, minimizando-se os efeitos agressivos da meteorização. Daí a sua compacidade e a continuidade da configuração cupuliforme do monte-ilha.

Enquanto as rochas graníticas são precâmbricas, as superfícies topográficas em que os montes-ilhas estão expostos datam da parte média ou final do Terciário, se reportarmos esta datação à que é atribuível às couraças lateríticas (Pliocénico), quer nos depósitos da depressão onde confluem o Cambongo e o Luambimbe, seu afluente da margem direita, depois de deixarem os maciços da Montanha Marginal onde têm as cabeceiras, quer em vasto sector da bacia próxima do Cuvo-Queve. A localização das crostas ferruginosas parece estar ligada com terminações de depósitos fanglomeráticos na base de vertentes montanhosas. Nalguns pontos pudemos ver que abaixo das couraças estavam terraços fluviais e as passagens das primeiras para os segundos se fazia por pequenos desníveis ou degraus.

Em certas áreas é possível que a exposição dos montes-ilhas possa ser relativamente recente, sobretudo nas bacias de recepção de águas dos sistemas fluviais. Abrimos um pequeno parêntesis para sublinhar o uso da palavra exposição dos montes-ilhas e não a de exumação, porquanto supomos que esta só deverá ser aplicada no caso de haver a certeza de que a forma de relevo, depois de ter sido exposta subaereamente, foi encoberta ou fossilizada por materiais que assim a mantiveram enterrada; numa fase posterior, por ablação dessa cobertura, então será mais correcto dizer que o monte-ilha foi exumado.

Está provado que os domos monolíticos podem resistir a um ou mais ciclos de erosão, tendo como resultado a acentuação do seu relevo ou comando acima dos plainos que os rodeiam. Em vários lugares da África meridional foram 
encontrados testemunhos de duas grandes fases de desnudação no Terciário, com alterações climáticas importantes: a de erosão post-Africana e no Pliocénico (Bond, 1963). Por isso mesmo também se poderá admitir que a exposição subaérea das partes mais elevadas dos montes-ilhas seja mais antiga que as mais baixas e que tais formas foram sendo expostas em fases com episódios de meteorização profunda e erosão dos plainos, o que contribuiu para a considerável altitude delas. Neste caso importa considerar também o grau de intervenção de factores tectónicos. Os climáticos contribuem para a meteorização, quer superficial, quer profunda.

As modificações climáticas do final do Quaternário promoveram alterações das paisagens, testemunhadas por formas de alta energia - ravinamentos, quedas de blocos, deslizamentos de massas detríticas em larga escala e depósitos de vários tipos, muitos deles de elementos grosseiros e não calibrados e formas de fraca energia, que referiremos a seguir. Contudo, não é fácil dizer qual o número de eventos catalisadores, embora se possa postular pelo menos um de grande importância geomórfica, na transição do Plistocénico para o Holocénico, pois em muitos lados da África meridional se têm encontrado testemunhos da ocorrência, nessa altura, de quantidades de chuvas mais abundantes do que as actuais, que promoveram a rápida transferência de sedimentos das vertentes para partes baixas, onde foram armazenados acima dos fundos dos vales. Assim se formaram rampas e lóbulos que cobriram várias superfícies topográficas, alterando o seu recorte.

Seguiram-se fases de acalmia, como sucede actualmente. Nas paisagens dos nossos dias predominam as formas de fraca energia. Os deslocamentos profundos de massas detríticas parecem inactivos, embora possam ocorrer deslizamentos após chuvadas tempestuosas. Muitas das vertentes de declives intermédios mantêm-se cobertas por depósitos espessos, os leitos das ribeiras intermitentes estão atapetados por sedimentos arenosos finos e, em regra geral, os canais dos rios activos raramente exibem materiais grosseiros. Os vales, quase rasos, com os seus fundos planos e largos, são definidos por vertentes em rampa, suavemente inclinadas, e as ravinas que nelas se abrem parece concentrarem cheias pouco frequentes, pois são modestos os sinais de colapso das margens e as cabeceiras mostram-se pouco erodidas.

Em muitos pontos, sobretudo em sectores depressionários, os depósitos aluvionares, essencialmente argilo-arenosos, que tudo leva a crer plistocénicos, atingem espessuras de 8 a $10 \mathrm{~m}$ sobre o bedrock granítico. Por outro lado, taludes que encobrem os sectores inferiores de muitas vertentes não estão demasiado dissecados. Há mesmo uma relação íntima entre fluxos de detritos, fanglomerados e colúvios, o que sugere a sua formação em condições semelhantes. 
O Rio Cambongo-Negunza e os seus afluentes:

um exemplo da complexidade de padrões de drenagem em Angola

\section{BIBLIOGRAFIA}

Amaral I do (1973a) Nota sobre o karst ou carso do planalto da Humpata (Huíla) no Sudoeste de Angola. Garcia de Orta - Série de Geografia, 1(2): 29-36.

Amaral I do (1973b) Contribuição para o conhecimento do karst ou carso de Nova Caipemba, no Noroeste de Angola. Garcia de Orta - Série de Geografia, 1(2): 1-28.

Amaral I do (1969) Inselberge (ou montes-ilhas) e superfícies de aplanação na bacia do Cubal da Hanha, em Angola. Garcia de Orta, 17(4): 475-526.

Barbosa L, Grandvaux A (1970) Carta Fitogeográfica de Angola. Instituto de Investigação Científica de Angola, Luanda.

Bond G (1963) Environments in East and South Africa since the Mid-Terciary. South African Journal of Science, 59: 347-352.

Bornhardt W (1900) Zur Oberflächengestaltung und Geologie Deutsch-Ostafrikas. D. Reimer (E. Vohsen), Berlim.

Büdel J (1957) Die doppelten Einebnungsflächen in den feuchten Tropen. Zeitschrift für Geomorphologie, 1(2): 201-228.

Carta Geológica de Angola na escala de 1:100 000 (1961/1972). Direcção Provincial dos Serviços de Geologia e Minas, Luanda.

Feio M (1982) O curso subterrâneo do rio Negunza (Angola). Finisterra - Revista Portuguesa de Geografia, XVII(33): 153-159.

Feio M (1981) O relevo do Sudoeste de Angola. Estudo de geomorfologia. Junta de Investigações Científicas do Ultramar, Col. Memórias, Lisboa.

Feio M, Brito R S (1950) Les vallées de fracture dans le modelé granitique portugais. Comptes Rendus du XVIe Congrès International de Géographie, I(2): 154-162.

King L C (1962) The Morphology of the Earth. A study and synthesis of the World scenery. Oliver and Boyd, Edimburgo.

King L C (1953) Cannons of landscape evolution. Bulletin of Geological Society of America, 64: 721-752.

Lapão L G P (1972) Notícia Explicativa da folha 184 - Novo Redondo, da Carta Geológica de Angola, escala 1:100 000. Direcção Provincial dos Serviços de Geologia e Minas, Luanda.

Mangin A (1975) Contributions à l'étude hydrodinamique des aquifères karsiques. Annales de Spéléologie, 30: 21-214.

Mangin A (1974) Contributions à l'étude hydrodinamique des aquifères karsiques. Annales de Spéléologie, 29: 283-601.

Moreira A F D (1971) Notícia Explicativa da folha 186 - Ebo, da Carta Geológica de Angola, escala 1:100 000. Direcção Provincial dos Serviços de Geologia e Minas, Luanda.

Peres A M, Moreira A F (1961) Notícia Explicativa da folha 185 - Vila Nova do Seles, da Carta Geológica de Angola, escala 1:250 000. Direcção Provincial dos Serviços de Geologia e Minas, Luanda.

Silva M V S (1971) Notícia Explicativa da folha 207 - Gungo, da Carta Geológica de Angola, escala 1:100 000. Direcção Provincial dos Serviços de Geologia e Minas, Luanda.

Twidale C R (1973) On the origins of sheet jointing. Rock Mechanics, 5: 163-187.

Wayland E J (1933) Peneplains and some other erosional platforms. Annual Report and Bulletin Uganda, 1: 376-377. 
Williams P W (1985) Subcutaneous hydrology and the development of doline and cockpit karst. Zeitschrift fur Geomorphologie, 29: 463-482.

Williams P W (1983) The role of the subcutaneous zone in karst hydrology. Journal of Hydrology, 61: 45-67. 


\title{
PLANNING PROCEDURES TOWARDS HIGH CLIMATIC QUALITY CITIES. EXAMPLE REFERRING TO LISBON
}

\author{
MARIA JoÃo AlCOFORADO ${ }^{1}$
}

\begin{abstract}
The different stages of research on high climatic quality city are presented in this paper: acquisition of appropriate urban climate information, analysis of different urban climate features and selection of planning strategies (accordingly with the climate zone). Then, with the aid of a GIS, systematic guidelines for planning can be given. As a result, different types of benefits for city dwellers are to be expected (comfort, health, economic). Lisbon is presented as a case study. It is shown how the "translation" of the knowledge of Lisbon's urban climate into simple guidelines for urban planning in order to mitigate the urban heat island, promote ventilation and increase air quality, was carried out. To this end, maps of the physical features of the city of Lisbon were drawn, synthesised into "urban homogeneous units" maps. Climate guidelines are specified for six groups of units (brought together according to urban morphology, topography and position in town).
\end{abstract}

Key words: Urban planning, climate guidelines, urban climate, Lisbon, Portugal.

Resumo - MEdidAs DE ORDENAMENTO PARA MELHORAR A QUALIDADE DO CLIMA URBANO. EXEMPLO REFERENTE A LISBOA. As diferentes fases da investigação para uma melhor qualidade do clima urbano são enunciadas: aquisição de dados segundo regras precisas, análise das características do clima urbano e selecção de estratégias para o ordenamento (em função da zona climática). A partir deste estádio, é possível enunciar orientações para o planeamento. O caso de Lisboa é apresentado como exemplo. É proposta uma metodologia para "traduzir" os conhecimentos sobre o clima urbano de Lisboa numa série de orientações para o ordenamento, com o intuito de mitigar a ilha de calor, promover a ventilação e aumentar a qualidade do ar. Neste sentido, foram elaborados mapas das características físicas da cidade de Lisboa, depois sintetizados no mapa das "unidades urbanas homogéneas" (agrupadas em função da morfologia urbana, topografia e posição na cidade): para cada uma destas unidades foram enunciadas orientações para o planeamento.

Palavras-chave: Ordenamento urbano, orientações climáticas, clima urbano, Lisboa, Portugal.

1 Investigadora do Centro de Estudos Geográficos da Universidade de Lisboa e Professora Catedrática do Departamento de Geografia. E-mail: mjalc@fl.ul.pt 
Résumé - Mesures Pour améliorer la QuAlité du Climat uRBain. ExemPle DE LisBOnNE. Les différentes étapes de la recherche pour contribuer à la qualité du climat en ville sont présentées : acquisition de données climatiques urbaines suivant des règles précises, analyse des caractéristiques du climat urbain et sélection de stratégies pour l'aménagement (en fonction de la zone climatique). Finalement des recommendations pour l'aménagement peuvent être présentées (sous forme de documents cartographiques, avec utilisation de Systèmes d'Information Géographique ou de textes). Le cas de Lisbonne est cité comme exemple. On propose une méthodologie pour "traduire" les connaissances sur le climat urbain de Lisbonne en une série de recommendations pour l'aménagement, avec l'objectif de mitiger l'îlot de chaleur urbain, promouvoir la ventilation et augmenter la qualité de l'air. Plusieurs cartes des caractéristiques physiques de la ville ont été préparées, qui ont conduit à une carte de synthèse des "unités urbaines homogènes" (des points de vue de la morphologie urbaine, topographie et position en ville); des mesures ont été enoncées pour chacune de ces unités.

Mots-clés: Aménagement urbain, recommendations pour l'aménagement, climat urbain, Lisbonne, Portugal.

\section{INTRODUCTION}

Climate can be seen as a resource for different objectives such as freshwater availability, food security, renewable energies, human health, integrated planning and tourism. This paper deals with integrated planning issues. Mills (2006) clearly stated, "as the global population becomes urbanized and human activity is concentrated in urban areas, settlement planning is the key aspect of sustainability". However, "economic and social demands are frequently in conflict with environmental issues" (Fehrenbach et al., 2001). Among the latter, there are laws limiting noise, air and water pollution and favouring biodiversity, but until now "local climate still is of minor importance for urban and regional planning" (Fehrenbach et al., 2001). The aim of this paper is to show that the systematic inclusion of urban climate knowledge into the planning processes is crucial for a better quality of life in cities. Last but not least, as man grows more aware about the problems of global warming and temperature rise in cities, it seems wise to follow the advice "think global, act local".

\section{THE METEOROLOGICAL UTOPIAN CITY: FROM LANSBERG TO MILLS}

Climate is an aspect of the urban physical urban environment that can be improved, although the metutopia, defined by Landsberg over 30 years ago, may never be attained. As early as 1973 Landsberg warned that "there are some sound meteorological principles that must begin to penetrate the planning process". Several very simple rules are listed such as not using flood 
plains for urban areas; unfortunately there are many examples that show that this advice should have been taken. In order to avoid summer urban heat island (see III.2.) in the utopian city, surfaces covered by vegetation should be as large as possible (if possible natural trees and shrubs, as grass often dries out in summer) and parking lots should be replaced by underground parking. Buildings should be high so as to occupy less space and anthropogenic heat should in winter be "channelled through smoke sewers (...) to melt snow that cause accidents and traffic jams". He describes other measures to avoid wind channelling by streets, air pollution and noise, pointing out consequences that bad environment would have on city dwellers. Other measures are put forward, not all of them accepted by everyone such as the use of atomic energy. It is quite interesting to note that Landsberg was already writing about "air resource" (p. 88). From his standpoint this resource had been "overexploited if not depleted". He was probably thinking about air pollution that was (and still is) destroying "otherwise pleasant climatic settings". Landsberg's approach has been brought back by some other authors. Bitan (1992: 313) was one of the first authors who distinguished urban air quality (air pollution, that must be controlled) from climate quality: "by correct usage of different climatological elements and their correct integration in different levels of planning (...), one can lead up to the improvement of local climates". He gives an example of a city with no air pollution problems, but with poor climate quality for the urban population (taking into account ventilation, sun rights or shade areas, excessively high temperatures, etc.). A decade later, Mills (2003: 227) presented a paper at the International Conference on Urban Climate (ICUC5) in Lödz, on "The meteorologically utopian city revisited", in which he states that "the new urban utopia is the sustainable city". He highlights the "consequences of design decisions carried out to solve different problems at varying scales". From his paper and a subsequent one (Mills, 2006), the reader will see that the planning objectives must be analysed at three different scales (settlement, building groups and individual buildings); furthermore, in some cases conflicts arise between the solutions carried out at the three different scales, and the planner must be aware of this.

\section{PROCEDURES TO ACHIEVE A HIGH CLIMATIC QUALITY CITY}

\section{The use of climatic information (2, fig. 1)}

The first step to improve urban climates is to study them (3, fig. 1) using climatic information (2, fig. 1). Meteorological stations (either traditional or automatic), complying with WMO rules, provide useful data to understand climate at the macroclimatic scale. However, these data are not appropriate for urban studies, due to the spatial scale of study and to the particular atmospheric processes that occur in the urban atmosphere. 
In the last decades, several developments have led to the improvement and normalisation of measurement methodologies and techniques of data acquisition in urban areas. Following Grimmond (2006), three aspects should be highlighted:

- Improved and more affordable instrumentation is now available to researchers due to the advances in technology, even in countries where only reduced sums of money are channelled into climatologic research. It is now possible to purchase reliable and accurate temperature and humidity sensors with data loggers, whereas some years ago only very expensive meteorological stations were available. A set of data loggers installed in key points in towns has replaced most of the mobile surveys, which were very time-consuming and had very limited temporal significance.

- Progress in urban atmospheric processes has led to a greater awareness of the importance of selecting correctly the location site for meteorological instrumentation in towns, either data loggers or meteorological stations. Fortunately, the "Initial guidance to obtain representative meteorological observation at urban sites" is now available (Oke, 2004). It is clear that location rules are different for studies carried out at different scales. In Lisbon, where both mesoclimatic and microclimatic temperature surveys were carried out during the CLIMLIS Project ${ }^{2}$, sites were chosen according to Oke's advice. In a first project, well distributed sites within the city, all with high sky view factors ${ }^{3}$ (SVF), were used to obtain information on temperature spatial variation in town ("settlement" scale), according to local climate factors and weather type (Alcoforado and Andrade, 2006). On a second project, which studied differences included in a single city district ("group of buildings" scale), data loggers were located in sites with different canyon geometry, street orientation and land cover, so that the causes of microclimatic differences could be inferred (Andrade and Alcoforado, in press).

- In order to prepare the way for future generations of researchers, a database of current studies, including metadata pertaining to measuring sites should be available. Researchers often have access only to long lists of figures with no information being provided regarding site exact location (latitude and longitude in degrees and minutes is insufficient), characteristics and site changes of meteorological stations; these are serious obstacles to the production of accurate work.

2 Prescription of Climatic Principles in Urban Planning. Application to Lisbon (Portugal) http://www.ceg.ul.pt/climlis/recent_dev.htm

3 The sky view factor is the "ratio of the amount of the sky 'seen' from a given point on a surface to that potentially available" (Oke, 1987: 404). 


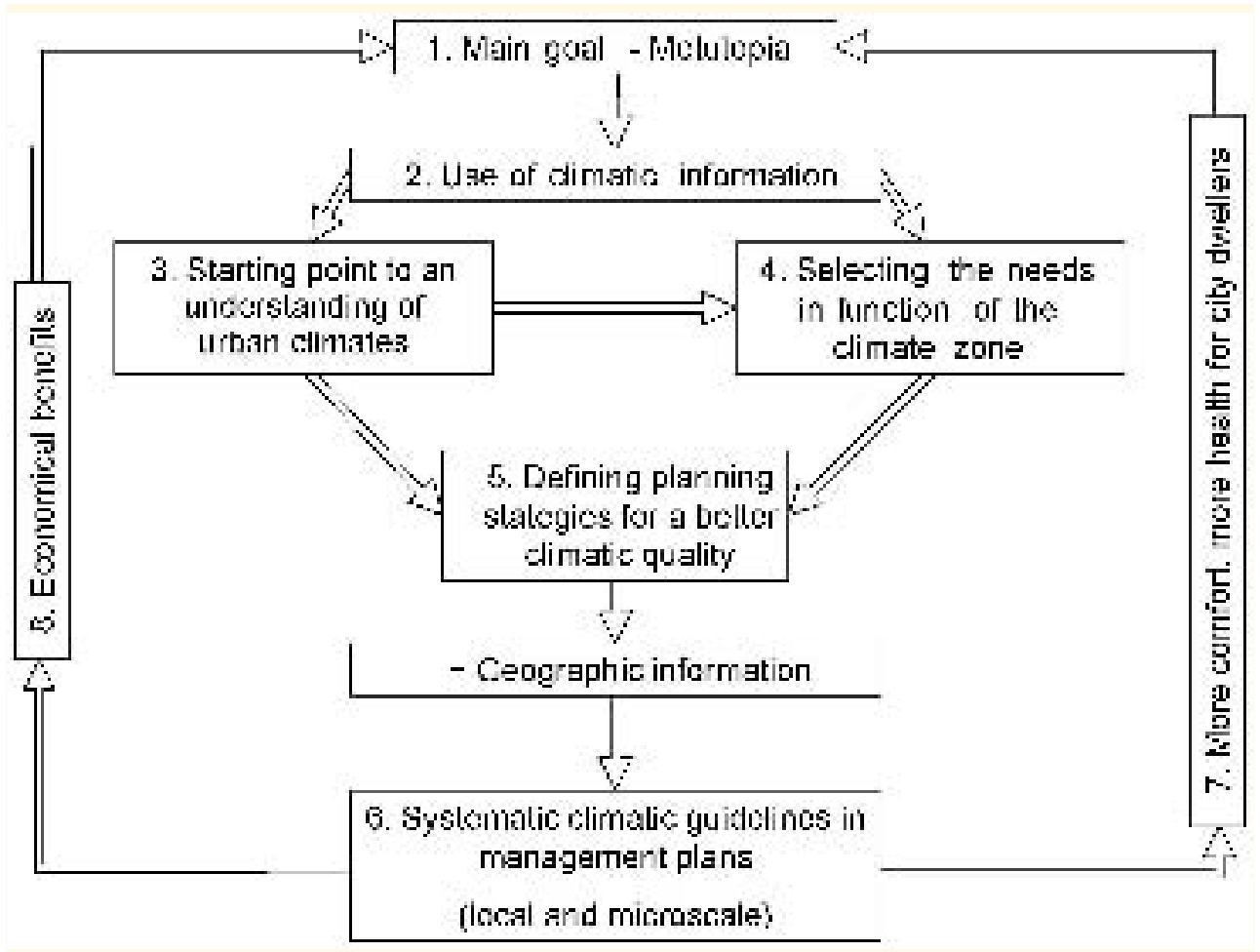

Fig. 1 - Flowchart showing the different stages of research towards a sustainable urban development.

Fig. 1 - Fluxograma ilustrando os diferentes estádios da investigação climática como contribuição para o desenvolvimento urbano sustentável.

\section{Starting point to an understanding of urban climates (3, fig. 1)}

For several decades now, climate data has provided the basis for scientists to get to know the characteristics of urban climates at different spatial and temporal scales. Since Kratzer's first manual in 1937, a number of review works on current knowledge of urban climate have been published: books by Landsberg (1981), Fezer (1995) and Oke (1987), papers by Oke (1988), Lowry (1998) and Arnfield (2003), among many others. Nowadays, statistical, scale and numerical modelling play a very important role. Nevertheless, climatic information will continue to be necessary, either to construct some of the models and/or to validate them. Furthermore, the aim of research should be to establish "general relations" and understanding the processes that cause urban climate rather than to continue mere studies of single cities (Oke, 2006).

Temperature, wind and air pollution, which are strongly dependent on cities morphology and anthropogenic activities, seem to be the main characteristics of urban climate. Anthropogenic activities can, to some extent, be "controlled" through meti- 
culous and informed planning. With regard to air temperature, the frequently used term urban heat island (UHI) refers to areas within the city, where the canopy and the boundary air layer temperature or the surface temperatures are higher than those of rural surroundings. The classical scheme by Oke (1987) shows air temperature rising from the suburbs towards the city centre. The temperature increase is not regular, but depends heavily on urban structure. The difference between urban and rural temperature is called UHI intensity (see Oke, 2006: 9). The UHI is more frequent and more intense during night time in most cities and during the dry season in tropical urban areas (Jauregui, 1997). The gradient wind is usually slowed down in the urban areas, although urban geometry may cause unwanted acceleration due to channelling along some streets or the venturi effect. Conversely, country and sea breezes may be intensified due to UHI. Cities are major sources of pollutants, which can be removed depending on the dispersion capability of the atmosphere (Batchvarova and Gryning, 2006) and also on wind speed and direction. UHI may intensify photosmog, but it also raises the mixing height, so its final effect on air pollution is not easy to predict (Rosenfeld et al., 1995). In cities, where topography and urban structure contribute to slowing down the wind, pollution problems can be very serious.

\section{Selection of the needs for different climate zones (4, fig. 1)}

Through the use of climatic information and the results of urban climate studies ( 2 and 3 , fig. 1 ) one is able to identify the climatic needs of cities within the studied area. The main requirements to mitigate negative impacts of urban climate will be briefly described according to the climate zone (Givoni, 1998; Brazdel and Martin, 1997; Alcoforado and Matzarakis, in print).

In hot areas, either humid or arid, UHI is a negative feature of the urban climate and must be mitigated. In hot humid climates it is necessary to reduce solar radiation and UHI. Furthermore, ventilation should be maximized and flood risks minimized. In hot arid climates measures should be taken to reduce solar gain and UHI, to increase evaporation in order promote cooling (green areas are effective if water is available for irrigation) and to minimize wind exposure.

In cold climates UHI is a positive feature, as it contributes to saving heating energy and it increases people's comfort on the streets; consequently, it must be favoured unless other negative consequences emerge (stagnant air between buildings may lead to enhanced air pollution); it is also necessary to maximize solar gain and minimize both wind exposure and snow accumulation (Zrudlo, 1988).

In areas with contrasting thermal seasons is UHI a positive or a negative feature? The UHI can be positive in winter, but threatens human comfort and health in summer. From the economic point of view, energy saving in winter is less important than the extra expenses of cooling cities in summer (in countries that can afford it, of course). Higher temperatures have additional negative consequences (oxidant pollution, bacteria multiplication, etc.). Consequently, in some cities such as Los Angeles and Athens, advice is given to planners to mitigate urban heat island (see also 4.1.). However, case-to-case evaluation must 
be carried out and solutions found accordingly, particularly in areas with climates with contrasting seasons.

\section{Defining planning strategies}

\subsection{General strategies (5, fig. 1)}

The next step is to use climatic knowledge when designing and planning at different spatial scales by choosing planning strategies for a better climatic quality (see also Alcoforado and Matzarakis, in print).

Mitigation of the UHI, for example, may be achieved through the modification of surface properties (Emmanuel, 2005) or street geometry (increasing the sky-view factor) whenever possible, reducing building density, integrating water bodies or green areas (Akbari et al., 2001; Ca et al., 1998). Yu and Hien (2006) consider that even in a humid hot climate like Singapore, the energy balance of the city may be modified by green areas (urban parks, rooftop gardens), as more absorbed energy "can be dissipated in form of latent heat rather than sensible heat". In a city with a Mediterranean climate like Lisbon, temperatures inside an 8.5 ha urban park (Gulbenkian Park) are on average (for a 60 days summer period) $1^{\circ}$ to $3^{\circ} \mathrm{C}$ lower than the nearby streets (Andrade and Vieira, 2005). Most frequently, the influence of the cooler air is not felt outside the park vicinity unless the topographical asset helps cold air drainage from the park into the nearby city-districts (Andrade, 2003). Further research is needed to conclude if several small neighbourhood green areas are more efficient in cooling the urban air than a big urban park.

The wind can be controlled in two distinct ways. In some city districts or along streets where the ratio between the height of the buildings and the width of the street $(\mathrm{H} / \mathrm{W}$ factor) is large, protection from strong winds must be created. But in most cases gradient winds are slowed down due to urban roughness: measures must then be taken to create open paths throughout the city to help ventilation. Country or sea breezes are sometimes very positive factors that enhance climate quality in town (Barlag and Kuttler, 1990/91), but sea breezes can also increase pollution in certain cases (Oke, 1987; Simpson, 1994). If new city districts are projected for a certain area, it is possible, through numerical or scale models, to identify beforehand the sites where the wind speed will be too strong, and the original plan can then be modified (Lopes, 2003; Baumüller et al., 2005).

Another problem is how to promote air quality in towns. This is not only a climatic problem and it depends a great deal on emissions, which are regulated by law and have numerous sources such as domestic heating (or cooling), industrial activities and vehicle emissions. Air quality can be improved by decreasing emissions and creating ventilation paths.

4.2. Strategies adapted to case-studies (6, fig. 1)

At this stage, it is possible to select planning strategies adapted to a particular city (6, fig. 1), using the result of the research carried out in 3 (fig. 1), based 
on climatological data and on different modelling strategies and taking into account the particular needs of the climatic zone where the city is located (4, fig. 1).

In 1984, Oke wrote that only a small amount of urban climate knowledge had permeated to urban planners due to "inherent complexity of the subject, its interdisciplinary nature and lack of meaningful dialogue between planners and the climatological research community" (p.1). Since then only a few papers have shown that some steps have been taken towards the introduction of climatic principles in settlement planning. For example, in 1988 Bitan suggested a methodology that would enable planners, as well as architects, to integrate climatic information at all levels of planning, from the settlement planning to the design of buildings (Bitan, 1988: 1). The methodology is synthesised in a flowchart divided into five main stages three of which involve climatological data acquisition and processing (p. 4). In the same year Zrudlo presented a "climatic approach to town planning in the Arctic", where a case study was carried out on a wooden house Inuit settlement constructed by the Canadian government near the Hudson Bay. He identified sun, wind and snow as the major stressors in this area. The final plan takes into consideration not only individual plans drawn separately for each climate element, but also the conflicts arising among them. At the end a "synthesized plan (was produced) which offers maximum solar advantage, wind protection and minimum snow-drifting, contributing (...) to the efficient functioning of the town and to the general well-being, both physically and psychologically, of its inhabitants" (Zrudlo, 1988: 62-63).

Several climatic analysis on urban planning have been performed in Germany since 1970 . Firstly in the very densely populated $R u h r$ area, then in projects on the urban climate of Bavaria (several cities in southern Germany in 1980s), followed by many others including projects STUTTGART21 (Baumüller, 2005) and BERLIOZ on Berlin (all references and explanations are found in Matzarakis, 2005). In most of those works "synthetic climate-function maps" and maps containing guidelines for planning are presented. The "Climate booklet for urban development" (Baumüller et al., 2005) provides a very useful tool for planning related urban climate studies.

In the Graz area in Austria, the main climatic problems are inversion conditions, low ventilation, fog and high pollution levels: Lazar and Podesser (1999) presented detailed maps of areas still free from buildings and sites of "banned" or "restricted" construction.

Within the framework of the KABA Project (Klima Analyse der Region Basel, Scherer et al., 1999), two types of maps were produced: the climate analysis maps and climate recommendation maps for regional and urban planning. An automated classification of planning objectives for the consideration of climate and air quality in Basel region was made by the University of Basel work team (Fehrenbach et al., 2001). The main objectives were the "protection of sensitive areas, the improvement of problematic situations, risk assessment and reduction and recommendations for appropriate forms of land-use". This classification has the advantages of being operator-independent and it can be applied elsewhere. 
Other references and case-studies can be found in the IAUC Newsletter (http://www.indiana.edu/ iauc/), in sites from ICLEI (Local Governments for sustainability, http://www.iclei.org/index.php?id=643), the heat island group home page (http://eetd.lbl.gov/heatisland/), and several others.

Within the CLIMLIS Project (see footnote 2), climate analysis was carried out for urban planning in Lisbon (Portugal). Lisbon is located near the western coast of Portugal, at $38^{\circ} 43^{\prime}$ latitude $\mathrm{N}$ and $9^{\circ} 9^{\prime}$ longitude W. The city lies $30 \mathrm{~km}$ to the east of the Atlantic shore and right on the bank of the Tagus estuary, that is $15 \mathrm{~km}$ wide eastwards from Lisbon. The city covers $84 \mathrm{~km}^{2}$ and has circa 600 000 inhabitants. In the urbanized area, altitude is inferior to $160 \mathrm{~m}$, although the topography is highly differentiated: four main valleys run from the north to the south in the most southern part of Lisbon. To the west, the Monsanto Hill rises to just over $200 \mathrm{~m}$ (fig. 2a). The traditional centre lie near the river and the new centrality area is expanding northwards. Its climate is 'Mediterranean' meaning that the dry season is the warmest and there are contrasting thermal seasons.

The city's main climatic problems detected on the basis of previous research were: urban heat island (UHI), wind, air pollution and urban floods. As the latter was being studied elsewhere (Oliveira and Ramos, 2002), we have focused on the first three items. Lisbon's UHI has an average intensity of $3^{\circ} \mathrm{C}$ and the nocturnal thermal pattern is frequently like the one in figure $2 b$ (Andrade, 2003) : $^{4}$ the highest air temperatures occur mostly in the more densely constructed areas, both near the Tagus river bank and along the main circulation axis where construction has been in progress. Prevailing N and NW wind circulation is hindered by the densely built-up southern and central neighbourhoods. In the case of a strong north wind, the UHI is restricted to the southernmost city districts where not only topography but also built-up density creates sheltered conditions. By way of a numerical model, summer wind speed reduction until the 1980s (an important decade in Lisbon's urban expansion) was simulated (Lopes, 2002 and 2003). Wind speed decrease due to surface roughness was particularly important in the densely built-up southern city-districts and over the Monsanto hill (fig. 2a). Nowadays, construction keeps on progressing north of the boundary between the well ventilated northern districts and the southern areas (with very restricted ventilation, fig. 2a). There are still open spaces in the northern city-districts, where ventilation paths for prevailing $\mathrm{N}$ winds must unquestionably be kept free (Lopes, 2003). The Tagus breeze does not always penetrate very far inland, but it is a very important source of cool air for the riverside neighbourhoods. (Vasconcelos et al., 2004). Lisbon has not yet become a very polluted city, mainly on account of frequent winds and because the vertical temperature profiles that promote pollution concentration are not very frequent. However, legal thresholds are sometimes exceeded, as was the case on January 1993, when frequent anticyclonic calm conditions occurred (Andrade, 1996). It is also clear that for the good of air quality, air circulation should not be hindered.

4 Coloured figures are included in the electronic version (www.ceg.ul.pt/finisterra/index.htm) 
In order to draw a climate guideline map it was first necessary to prepare a cartographical basis with the physical characteristics of the city. Hence homogeneous climate response units ${ }^{4}$ (CR units from the point of view of urban morphology, topography and position in town) were represented in a 1:25 000 map. The work was carried out using a geographical information system. Several layers were necessary such as land use (based on a Landsat 7 image), height of buildings, Digital Terrain Model, etc.

Recommendations for planning purposes are given for each homogeneous unit or group of units according to the work scale; it is known that planners need very clear guidelines concerning areas whose limits are very precisely drawn in a detailed map. In fact, the maps of figure 3 show only the different groups of CR units defined on a "settlement" scale (1 to 6, fig. 3 ). The descriptive captions consists of tables where recommended measures to mitigate UHI, enhance ventilation and decrease air pollution in each unit group are listed. They are presented in detail in Alcoforado et al. (2005). Measures differ according to position and type of homogenous unit. For instance, setting up green areas in the northern part of the city (unit 1) may be advised to moderate UHI, while in the city core (unit 6), one can only recommend planting some deciduous trees in the few areas that are still left. In the northern part of the city large ventilation paths (unit 2) can still be preserved, while in the city centre, the only possible measure is to not obstruct the valley beds even further.

Similar methodology, this time also using scale modelling (Andrade, 2003; Lopes, 2003), was applied on a scale of "group of buildings" in a city district in the northern area of Lisbon where construction has been in constant progress (Andrade and Alcoforado, in press). Conflicts between planning measures at the two different scales had to be dealt with. For example, at the settlement scale, large ventilation paths were recommended; however, in the city-district under study, guidelines were given in order to provide shelter in outdoor areas used for leisure activities.

\section{CONSEQUENCES OF USING CLIMATE GUIDELINES IN URBAN PLANNING}

\section{Benefits in terms of comfort and health for city dwellers (7, fig. 1)}

Although there are other positive consequences for the city dweller including climatic recommendations in urban planning, only their effect on thermal

4 The methodology to limit these units was inspired by the different research works referred to at the beginning of this paragraph. The homogeneous climate response units may also be called morpho-topographical units, climatopes (VDI, 1998, Scherer et al., 1999) or be the synthesis of the areal type and ventilation classes, used in the work of Feherenbach et al., 2001. The methodologies and the denomination of these units are discussed in Alcoforado et. al. (2005). 
comfort will be presented here. Human comfort changes a great deal spatially and temporally and it is a highly subjective parameter. However, several attempts have been made to "quantify" the way in which the human body reacts while seeking its comfort zone. One of the most commonly used bioclimate comfort indices is the Physiological Equivalent Temperature (PET), first defined by
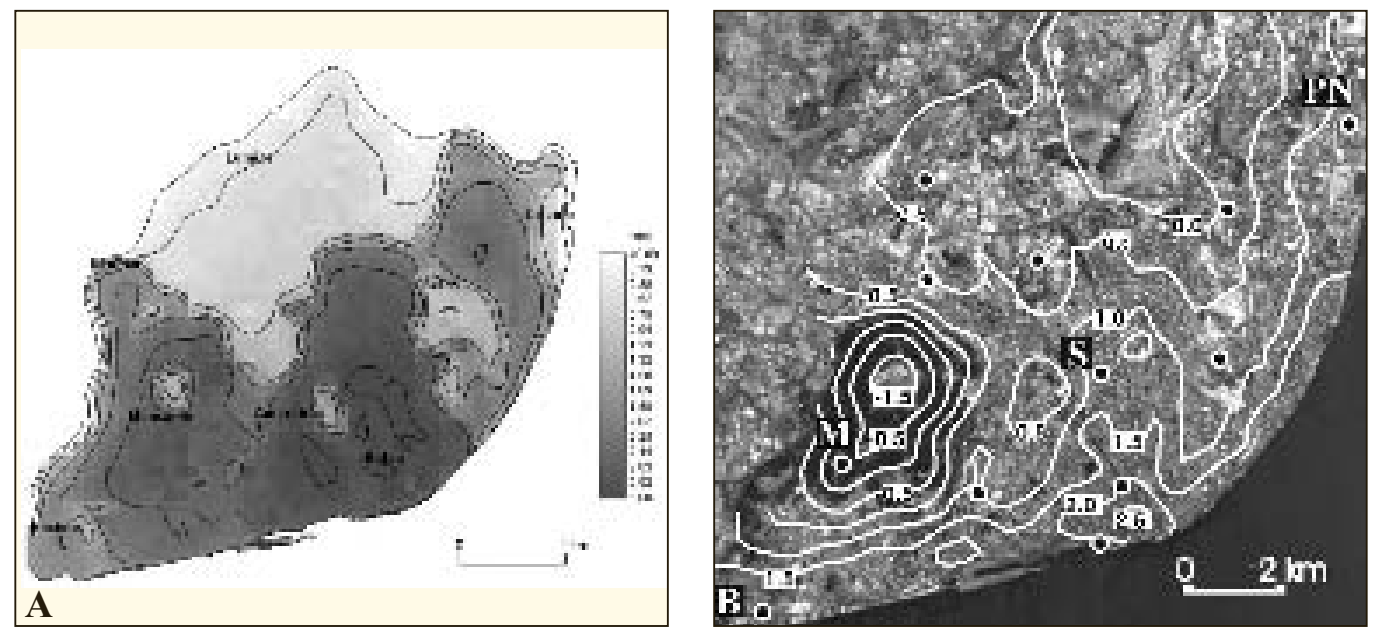

Fig. 2 - Examples of previous work on Lisbon's urban climate.

A) Wind speed reduction until the 1980s (Lopes, 2003); B) Frequent nocturnal thermal pattern (standardized temperatures, ${ }^{\circ} \mathrm{C}$, Andrade, 2003).

Fig. 2 - Exemplos de investigação preexistente sobre o clima urbano de Lisboa.

A) Redução da velocidade do vento até 1980 (Lopes, 2003); B) Padrão térmico nocturno frequente (temperaturas normalizadas, ${ }^{\circ} \mathrm{C}$, Andrade 2003)

Mayer and Höppe (1987) and Höppe (1993). This index is based on the energy balance of the human body and, according to Matzarakis, Mayer and Iziomon (1999), it allows for the evaluation of thermal conditions in a physiologically significant manner. It is used systematically in planning practices in Germany (Matzarakis et al., 2000; VDI, 1988) and is applied in the evaluation of different thermal environments, such as the UHI within cities. At the "settlement" scale, Andrade (2003) has shown that the highest values of PET in Lisbon occur in the UHI core and that PET differences between the suburbs and the city centre are even higher than UHI intensity. This means that changes in thermal environment, due to different planning measures, can be quantified by the use of PET and that UHI mitigation will lead to a decrease of thermal stress and, as a consequence, to a decrease in urban morbidity and mortality.

In rural areas, and more so in cities, additional health problems are expected as a result of global warming (WHO, 2005; Koppe et al., 2004). Conversely, "in cities stagnant weather conditions can trap both warm air and pollutants leading to smog episodes with significant health impacts"; moreover, recent 

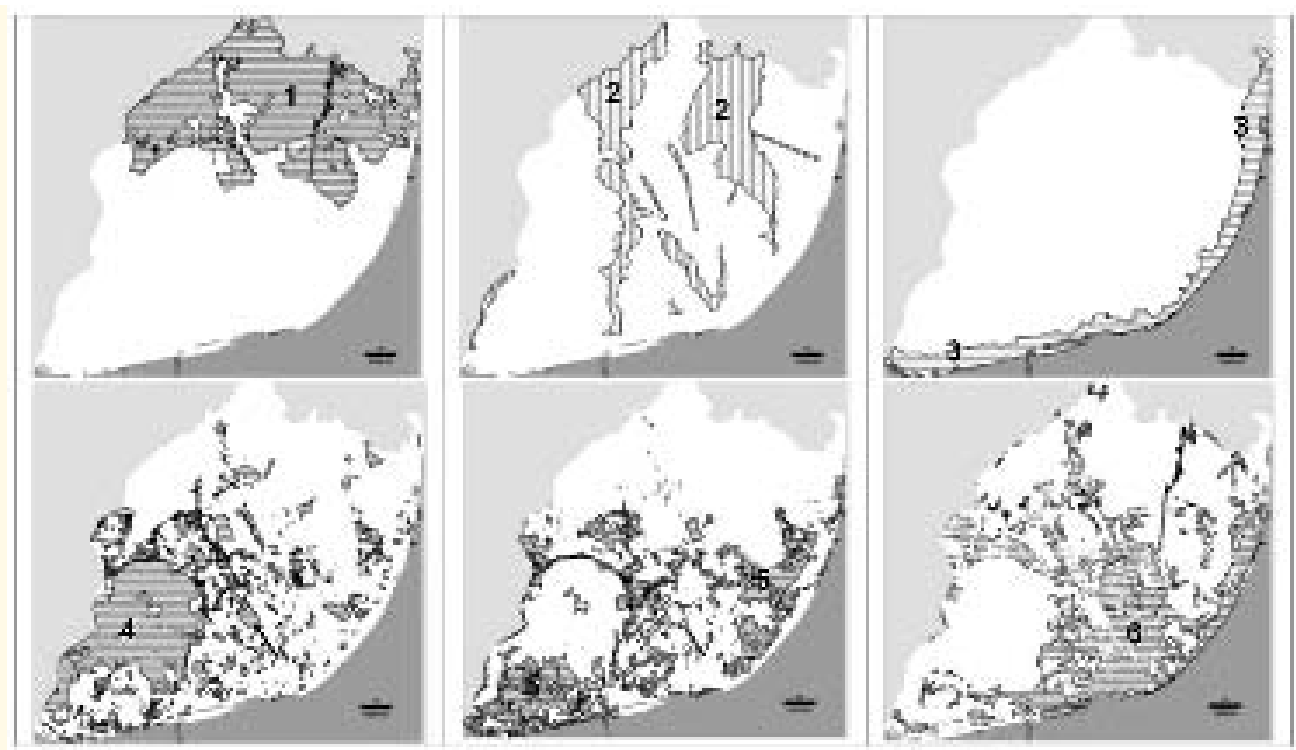

Fig.3 - Groups of homogeneous Climate Response Units for which climate guidelines were prepared (Lisbon, "settlement scale").

Fig. 3 - Grupos de unidades de resposta climática homogénea de Lisboa para as quais foram feitas recomendações climáticas (na escala mesoclimática).

analysis shows "that human induced climate change significantly increased the likelihood of the European summer heat wave of 2003" (WHO, 2005).

\section{Economical benefits for city dwellers $(8$, fig. 1$)$}

According to Oke (2006), there are few examples that illustrate the positive or negative impact of design inspired or informed by urban climate input. This is particularly true insofar as economic benefits are concerned. There is not yet an accepted common methodology to compute the costs and benefits of urban climate, mainly of the UHI. However, some figures were presented for cities with thermal contrasting seasons: Athens (Dimoudi and Nikolopoulou, 2003; Hassid et al., 2000), Los Angeles (Akbari et al., 2001) and Tokyo (Genchi et al., 2004). A more detailed account and some other references are given in Alcoforado and Matzarakis (in print). Some papers present figures to prove that the saving of energy in winter is lower than the surplus expenses for air conditioning in the summer. On the other hand, generalised air conditioning systems will represent an unwanted added heat load to the urban atmosphere. The problem can be more complicated to solve in areas with hot and humid seasons. Yu and Hien (2006: 119) computed $10 \%$ reduction of cooling load in buildings near a park in Singapore. However, the authors indicate that the energy used for dehumidifying was not considered in the simulation. Much research is still needed in this area. 


\section{CONCLUSION (back to 1, fig. 1)}

It is clear that some of the difficulties, pointed out by Oke (1984) and Eliasson (2000), concerning the application of urban climatology to planning of sustainable settlements, as has been briefly analysed here, have not yet been solved. Some climate studies are not directly usable by planners and some planners are not yet acquainted with the results of climate studies or even with the possibility of using climatic information. There is still, in some cases, a "communication" problem between climate scientists and planners, and even when they speak the same language "translation" problems often arise. Moreover, the ideal sustainable city does not look the same to climatologists and planners; e.g., the example of the compact city, supported by some planners for economic reasons (for instance, per capita energy use is much lower in high density cities). Climate scientists consider that the compact city leads to climatic problems, as inadequate ventilation in compact cities will lead to temperatures that are too high and to excessively high pollution levels, if no measures are taken to counteract them (Mills, 2006). As was pointed out in the case of outdoor comfort, and more so in the case of economic consequences, there are not enough measurable impacts of using climate knowledge in different planning levels.

However, several positive aspects must also be highlighted. From the examples presented and cited in this paper as well as from several others quoted by Eliasson (2000), Mills (2006) and Alcoforado and Matzarakis (in print), just to mention a few, it is clear that as climate is part of the physical environment it has its place in the urban planning process. Furthermore, in several ongoing applied studies the climate information used is not restricted to simple average values of the nearest meteorological station as it traditionally was. Urban climate knowledge is slowly being made known to the public and local authorities with the power to implement necessary measures. Some publications explain the advantages of using urban climate knowledge in planning procedures and give the planners tools to use climate information in their work or to fall back on climate researchers. The "booklet" edited by Baumüller et al. (2005) on the Internet in German and English now being translated into other languages (Matzarakis, 2005) is quite a good example. Following this initiative, climatologists and planners together should prepare a standard protocol so that future urban management plans systematically include climate guidelines. Maybe this way we will all get closer to meteorologically utopian cities.

\section{AKNOWLEDGEMENTS}

I would like to thank the members of the ET9 (OPAG3) of the WMO, those of the CLIMLIS team, Andreas Matzarakis and Eberhard Parlow, for the fruitful discussions about urban climate and planning issues, as well as Henrique Andrade for his very useful comments on a former version of this text. 
Furthermore, the comments of the reviewers of Finisterra must be thanked. The present text was adapted from a paper presented at the Beijing Conference on Climate Resources, in November 2005, where the author was sponsored by the WMO.

\section{REFERENCES}

Akbari H, Pomerantz M, Taha H (2001) Cool surfaces and shade trees to reduce energy use and improve air quality in urban areas. Solar Energy, 70: 295-310.

Alcoforado M J, Andrade H (2006) Nocturnal urban heat island in Lisbon (Portugal): Main features and modelling attempts. Theoretical and Applied Climatology, 84(1-3): 151-160. http://springerlink.com/content/w848535781465135/

Alcoforado M J, Andrade H, Lopes A, Vasconcelos J, Vieira R (2005) Orientações climáticas para $o$ ordenamento em Lisboa. Área de Investigação de Geo-Ecologia, Relatório n. ${ }^{\circ} 4$, Centro de Estudos Geográficos, Lisboa 81 p.

Alcoforado M J, Matzarakis A Urban climate and planning in different climate zones. Chapter of the new edition of WMO/TN 145, Geneva (in press).

Andrade H (2003) Human bioclimate and air temperature in Lisbon (in Portuguese). PhD Thesis, University of Lisbon.

Andrade H (1996) Air quality in Lisbon. Average and extreme values (in Portuguese). Finisterra-Revista Portuguesa de Geografia, XXXI(61): 43-66.

Andrade H, Alcoforado M J Microclimatic variation of thermal comfort in a district of Lisbon (Telheiras) at night. Theoretical and Applied Climatology (no prelo).

Andrade H, Vieira R (2005) The Climate of the Gulbenkian Park (Lisbon). Área de Investigação de Geo-Ecologia, Relatório n. ${ }^{\circ}$ 4, Centro de Estudos Geográficos, Lisboa (in Portuguese with an English summary).

Arnfield J (2003) Two decades of urban climate research: a review of turbulence, exchanges of energy and water, and the urban heat island. International Journal of Climatology, 23: 1-26.

Barlag A B, Kuttler W (1990/91) The significance of country breezes for urban planning. Energy and Buildings, 15/16: 291-297.

Batchvarova E, Gryning S (2006) Progress in urban dispersion studies. Theoretical and Applied Climatology, 84(1-3): 57-68.

Baumüller J (2005) "Stuttgart 21". Amt für Umweltschutz, Stuttgart [Acedido em 15 de Outubro de 2005]. http://www.stadtklima.de/stuttgart/websk21/Heft13/kap3.HTM

Baumüller J, Hoffman U, Reuter U (2005) Climate booklet for urban development. References for zoning and planning. Baden-Württemberg Innenministerium [Acedido em 16 de Outubro de 2005] http://www.staedtebauliche-klimafibel.de/

Bitan A (1992) The high climatic quality of the future. Atmospheric Environment, 26B(3): 313-329.

Bitan A (1988) The methodology of applied climatology in planning and building. Energy and Buildings, 11: 1-10.

Brazel A, Martin J (1997) Town planning, architecture and building, In Thompson and Perry (eds), Applied Climatology. Principles and Practice. Routledge, London: 175-186.

Ca V T, Asaeda T, Abu E M (1998) Reductions in air conditioning energy caused by a nearby park. Energy and Buildings, 29: 83-92. 
Dimoudi K, Nikolopoulou M (2003) Vegetation in the urban environment: microclimatic analysis and benefits. Energy and Buildings, 35: 69-76.

Eliasson I (2000) The use of climate knowledge in urban planning. Landscape and Urban Planning, 48: 31-44.

Emmanuel R (2005) Thermal comfort implications of urbanization in a warm-humid city: the Colombo Metropolitan Region (CMR), Sri Lanka. Building and Environment, 40: 1591-1601.

Fehrenbach U, Scherer D, Parlow E (2001) Automated classification of planning objectives for the consideration of climate and air quality in urban and regional planning for the example of the region Basel/Swizerland. Atmospheric Environment, 35: 5605-5615.

Fezer F (1995) Das Klima der Städte. Klett-Perthes Verlag, Gotha.

Genchi Y, Azuma T, Ohashi Y, Kikegawa Y, Inaba A (2004) Energy analysis of countermeasures for urban heat island effect. Proceedings of the 6th International Conference on EcoBalance, S2-6-1, Tsukuba, Japan: 4p.

Givoni B (1998) Climate considerations in building and urban design. John Wiley and Son, New York.

Grimmond C S B (2006) Progress in measuring and observing the urban atmosphere. Theoretical and Applied Climatology, 84(1-3): 3-22.

Hassid S, Santamouris M, Papanikolaou N, Linardi A, Klitsikas N, Georgakis C, Assimakopoulos D N (2000) The effects of the Athens heat island on air conditioning load. Energy and Buildings, 32: 131-141.

Höppe P R (1993) Heat balance modelling. Experientia, 18: 1-15.

Jauregui E (1997) Climates of tropical and subtropical cities. In Yoshino M, Domrös M, Douguédroit A, Paszynski J, Nkemdirim L (eds) Climates and Societies. Dordecht, The Geojournal Library, Kluwer: 361-373.

Koppe C, Jendritzky G, Kovats S, Menne B, Baumüller J, Bitan A, Díaz Jiménez J, Ebi K L, Havenith G, López Santiago C, Michelozzi P, Nicol F, Matzarakis A, McGregor G, Nogueira P J, Sheridan S, Wolf T (2004) Heat-waves: risks and responses. Regional Office for Europe. Health and Global Environmental Change, Series No. 2, Copenhagen http://www.euro.who.int/document/E82629.pdf

Kratzer A (1937) Das Stadtklima. Vieweg, Braunschweig.

Landsberg H (1981) The urban climate. International Geophysics series, 28, Academic Press, New York.

Landsberg H (1973) The meteorologically utopian city. Bulletin American Meteorological Society, 54(2): 86-89.

Lazar R, Podesser A (1999) An urban climate analysis of Graz and its significance for urban planning in the tributary valleys east of Graz Austria). Atmospheric Environment, 33: 4195-4209.

Lopes A (2003) Changes in Lisbon's urban climate as a consequence of urban growth. Wind, surface UHI and energy budget. (in Portuguese). PhD Thesis, University of Lisbon.

Lopes A (2002) The influence of the Growth of Lisbon on summer wind fields and its environmental implications. Proceedings of the Tyndall/CIB International Conference on Climate Change and the Built Environment, Manchester, UMIST, 9 p.

Lowry W P (1998) Urban effects on precipitation amount. Progress in Physical Geography, 22: 477-520.

Matzarakis A (2005) Urban climate research in Germany. IAUC Newsletter, 11: 4-6 http://www.indiana.edu/ iauc/ 
Matzarakis A, Mayer H, Iziomon M G (1999) Applications of a universal thermal index: physiological equivalent temperature. International Journal of Biometeorology, 43: 76-84.

Matzarakis A, Rutz F, Mayer H (2000) Estimation and calculation of the mean radiant temperature within urban structures. WCASP-50, WMO/TD No. 1026: 273-278.

Mayer H, Höppe P R (1987) Thermal comfort of man in different urban environments. Theoretical and Applied Climatology, 38: 43-49.

Mills G (2006) Progress towards sustainable settlements: a role for urban climatology. Theoretical and Applied Climatology, 84(1-3) 69-76.

Mills G (2003) The meteorologically utopian city revisited. Proceedings of the $5^{\text {th }}$ International Conference on urban Climate, Lodz, Poland, vol. 2: 227-230.

Oke T R (2006) Towards better scientific communication in urban climate. Theoretical and Applied Climatology, 84(1-3): 179-189.

Oke T R (2004) Initial guidance to obtain representative meteorological observations at urban sites. IOM Report, n. 81, WMO/TD No. 1250, Geneva, World Meteorological Organization, http://www.wmo.ch/web/www/IMOP/publications/IOM-81/IOM-81-UrbanMetObs.pdf

Oke T R (1988) The urban energy balance. Progress in Physical Geography, 2(4): 471-508.

Oke T R (1987) Boundary Layer Climates. Methuen, London, ( $2^{\text {nd }}$ ed.).

Oke T R (1984) Towards a prescription for the greater use of climatic principles in settlement planning. Energy and Buildings, 7: 1-10.

Oliveira P E, Ramos C (2002) Urban floods in Lisbon during the 20th century and its causes. (in Portuguese, with an English summary). Finisterra - Revista Portuguesa de Geografia, XXXVII(74): 33-54.

Rosenfeld A H, Akbari H, Bretz S, Fishman B L, Kurn D M, Sailor D, Taha H (1995) Mitigation of urban heat islands: materials, utility programs, updates. Energy and Buildings, 22: 255-265.

Scherer D, Fehrenbach U, Feigenwinter C, Parlow E, Vogt R (1999) Improved concepts and methods in analysis and evaluation of the urban climate for optimising urban planning processes. Atmospheric Environment, 33: 4185-4193.

Simpson J E (1994) Sea breeze and local wind. Cambridge University Press.

Vasconcelos J, Lopes A, Neto J, Salgado R (2004) Modelling estuarine breezes of Lisbon, Portugal. Preliminary results. Proceedings of the IV Conference of the Spanish Association of Climatology, Santander: 165-171.

VDI (ed.) (1988) Stadtklima und Luftreinhaltung. Springer-Verlag, Berlin.

WHO (2005) Climate and health. [Acedido em 07 de Fevereiro de 2006] http://www.who.int/globalchange/ news/fsclimandhealth/en/

Yu C, Hien W N (2006) Thermal benefits of city parks. Energy and Buildings, 38: 105-120.

Zrudlo L R (1988) A climatic approach to town planning in the Artic. Energy and Buildings, 11: 41-63. 
NOTAS 



\title{
GLOBALISATION, LOCALISATION AND THE WELFARE STATE
}

\author{
Christopher Jensen-Butlen ${ }^{1}$
}

Em 2004 convidámos Chris a participar numa reunião sobre Globalização e Localização que, com Antoine Bailly, organizámos em Alvito, numa iniciativa da associação Estudos Gerais de Alvito. Nessa reunião participaram alguns dos grandes nomes mundiais da Ciência Regional, que se deslocavam a Portugal por ocasião do Congresso da RSAI, que teve lugar no Porto. Chris aceitou, mas por motivos de saúde foi obrigado a cancelar a sua vinda; no entanto, não deixou de nos enviar a apresentação em Powerpoint. Publicar agora o texto dos slides é uma homenagem a alguém a quem muito devemos.

Jorge Gaspar

\section{What Is abtalkstba?}

1. A coisel chomariarco

Ll ch Eec: gitbolad:r kat

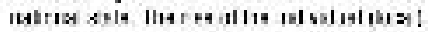

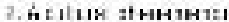

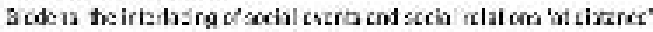

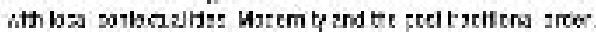

1. inferlyis teosageth

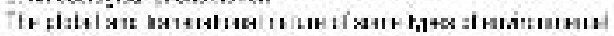

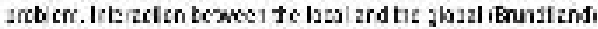

4. in orgurlastard omerotomar

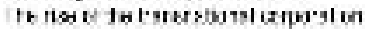

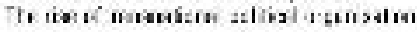

The ise of te reg ons wake

bets insubarets of tzi

Gobalkation as an Eetnank ptentrenen

\section{Octabala cri Trak}

\section{Fazoc mo:Ilte :upiblatd laboir}

3. Iะtas อาะ I1rovaten

4. brout1 n to ga:2 at:nor:

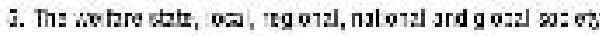

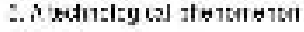

Dchor:

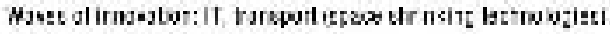
1extle trotutior spterte, ditlar

E. A) and-phernn:ron 1

Btoimat.

antis ahe is ofilse;

arfi ince: ial stinatain

art as zocat o 15 iWeit::

ard กn:cl aril

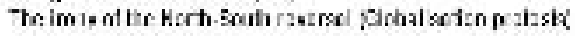

2.N gt:mank blstumgruT

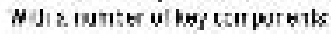

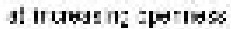

at locter notulis

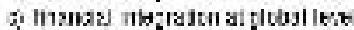

Nivi 192 (2)

\section{Olabalsatian and trode}

1.I The tradtensl asponct:

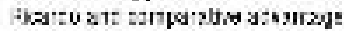

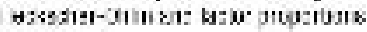

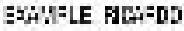

Aan airs to andus ase ut:

Trotica smo

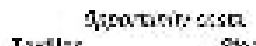

Fat $y$,

wher 5 is

T:atl:s

85: $: 1$

29:-ะ: 1

ลา มเแाน"

is?-1e

T'Joe is:

I me-17uss:

2. wars nzazdrg a.didutud:n or barells datec:s $01 x \cdot \pi 5$ o'l:2d

Crigirs:

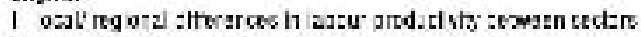

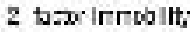

1 School of Economics and Finance, University of St. Andrews. 


\section{Few trabs theor,}

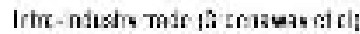

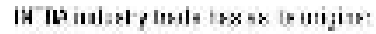

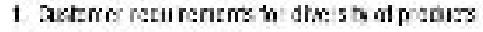

2 sele twa:rriat v. im

Resale:

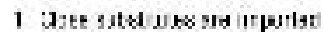

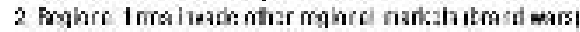
HIzhl, magrexd esaron es has mu:

\section{[ce:mano}

I nנjlltwe zutratage

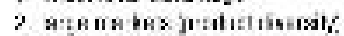

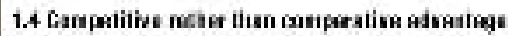

Porlar's :larrot:

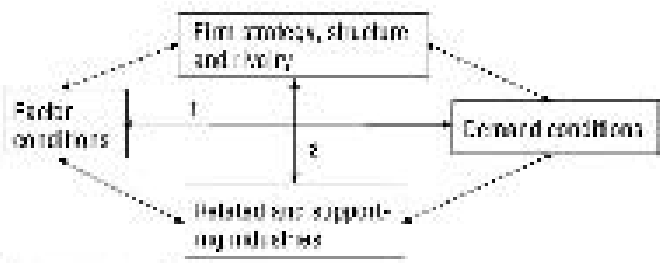

Crome ronociotiction

Earomine ias: nimal

22 Why teotrapty matters II) bumlers is 1acter mobilty

1. I1barrad:n

2. Poodiary zosz

3. H:n-tequiary asz: potto ogla, as zurl, In:ustc

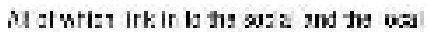

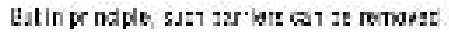

\subsection{Hew Ecoucrilo peaguph/ IKrugnany}

nivetras an tre'ucladsas: ts:

. szalt ccon:riss 2 mpat:cl comp:tyar

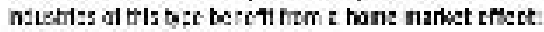

sa:ditons! mathe: zecses gics

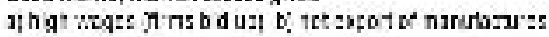

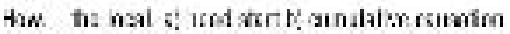

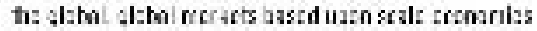
and iremedect remp:I thar

7.

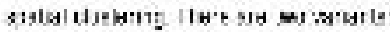

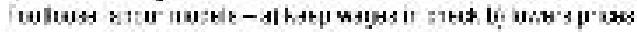

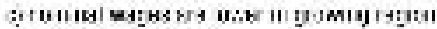

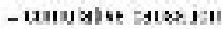

otrazal; | n<Ed Irodels: tiuss. Stllyutall?

\section{Fostor intifity}

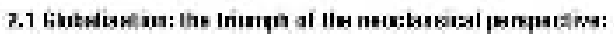

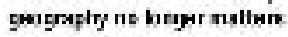

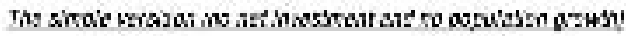
npios h

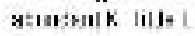

$-$

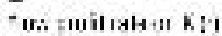

Dijl wajk IX) mpike $\mathrm{B}$

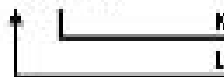

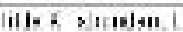

$I_{i}$

-

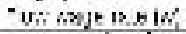

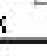

2.3 Wty gejoraing notters. Exteiraliks

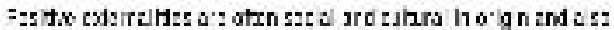

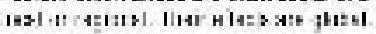

Exrijltos zre

- Whinitut

2. Pranier; ar wholozial

4. Satcatimust

7:

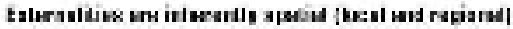

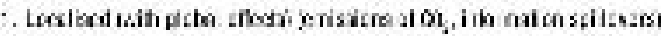

2. Le mited h pastiatol dars to Ir ther chas

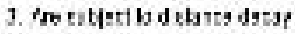

1. \&nsaly: I 


\section{Itess und imsvatian}

Kag tecte br al:teitestas:

1. Pro:uti protats irmasbur

2. Lushed v taztkrvilatga

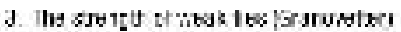

4. Umbotisd v alsontedig: barricyl grtgase

5. Sploser ellatk parus he rigrkal

6. Hetow'ke r clusher

M T2: g vas? 7 besl ditareiare

3.1.1 Whe detes nhes the rete of ahtuabn of new ideas? The cerrica-tprodel

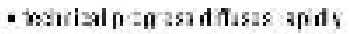

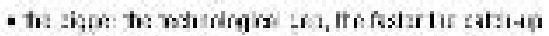

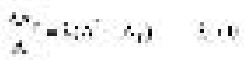

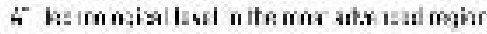

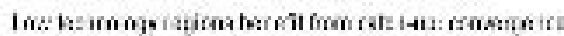

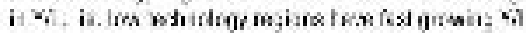

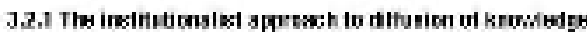

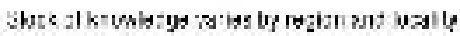

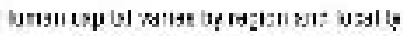

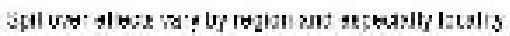

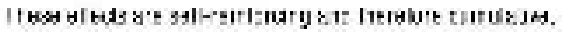

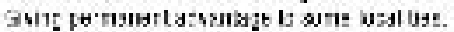

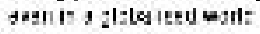

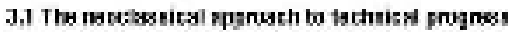

I ton

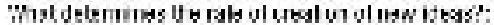

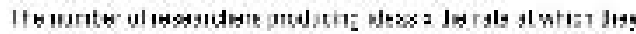

andace ITEI

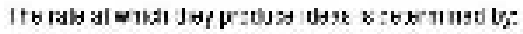

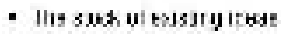

- llig zajeranistilivis.

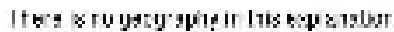

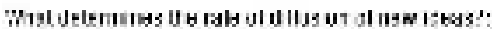

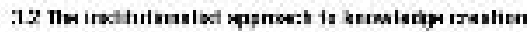

+ Galrs trer sronod:c 2czas to otersliur foss wto

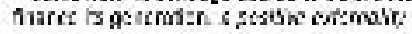

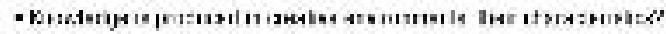
Dimosita

2. cerpexim: ach's

sivericts 1

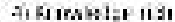

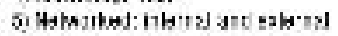

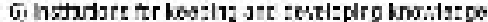

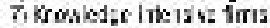

xiffinfe:roil ?

Trars adje a.:

ai cazjuryly suat fo

bi imrobl:

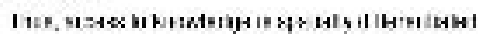
งา:

4. Tapdiniag grrath is the ghtslbest wark

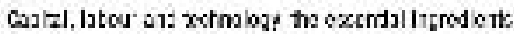

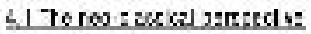

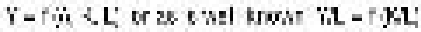

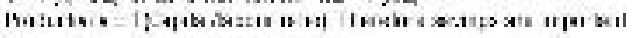

five-pat esterionifialisal

$\mathrm{K}$ capilal stock.

L:Istos:

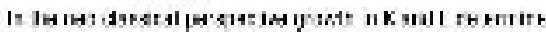

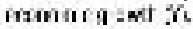

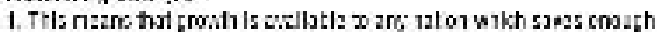

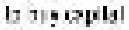

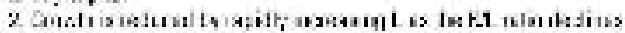

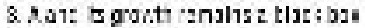

isist? gaval ista 

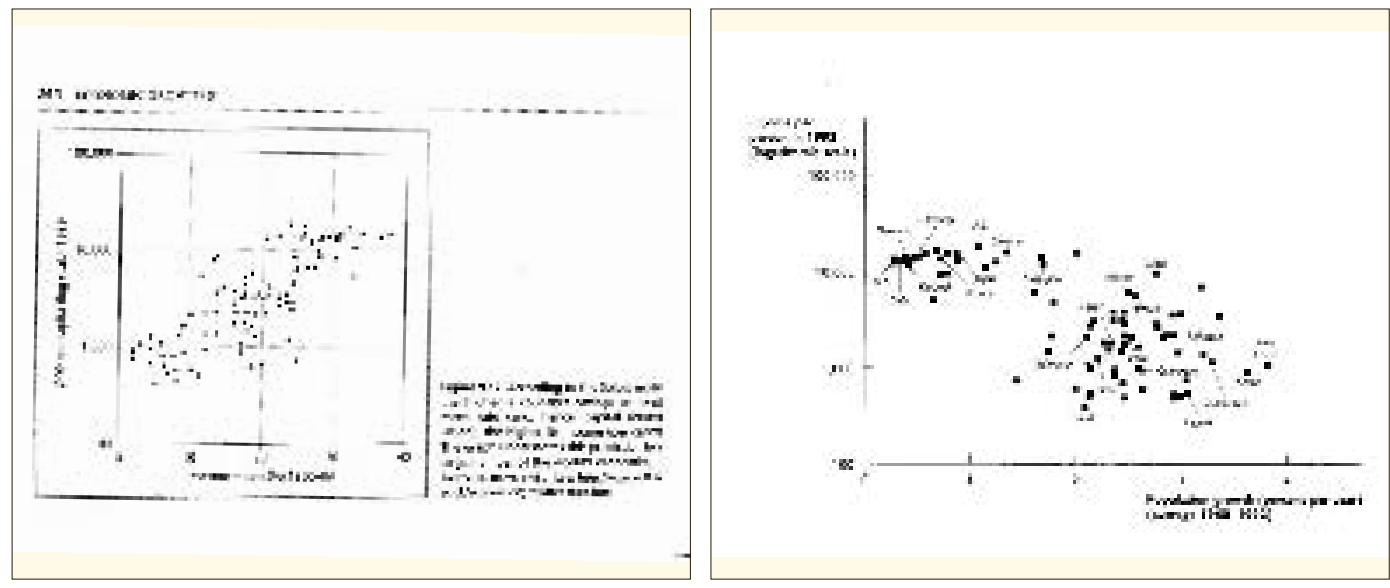

\subsubsection{A Heo classical wariant:}

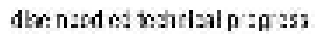

cotmis: be rrical arma css

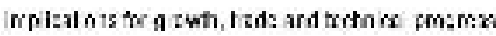

\subsubsection{The placl aco elasical view}

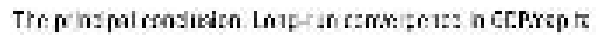

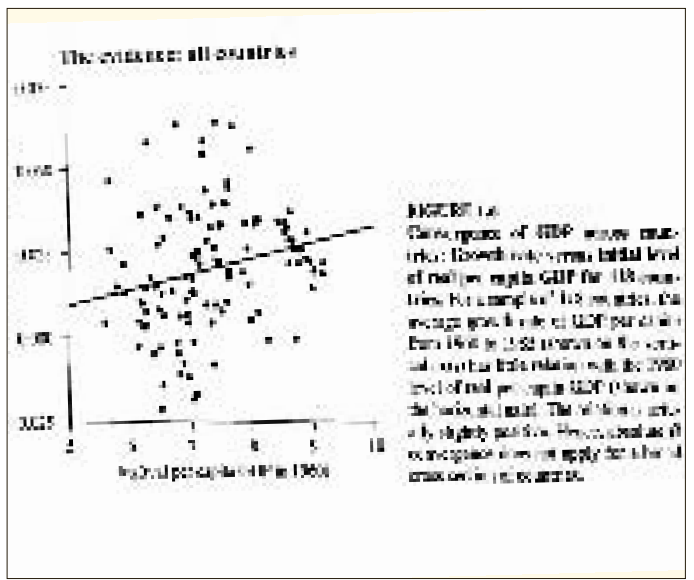

\section{Ta: iesthdikndbet perspoviat}

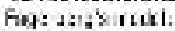

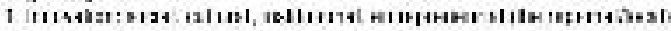

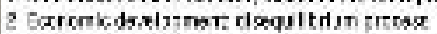

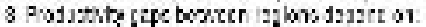

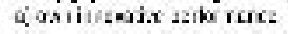

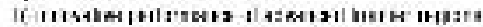

aithtoment

$0-20$ ก- $\mathbf{0}-$

पพบบ

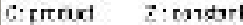

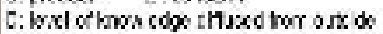

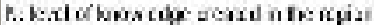

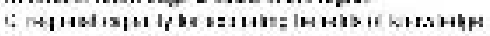

Ir wo ds, exercric growt diszers cr.

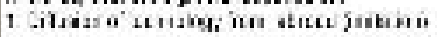

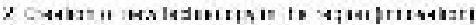

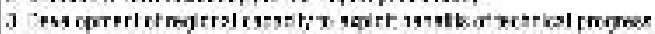

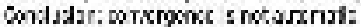




\subsection{Conbiring nocelastical ant insturtionalist thatry}

$\boldsymbol{\gamma}=\mathbf{A} \times \mathbf{L}$

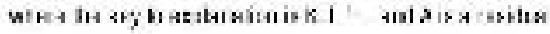

D $=$ 2 D-N-C -

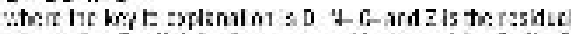

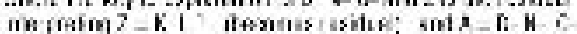

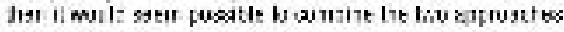

The sours:s of technce pro;mez are in tecir ricd:l.

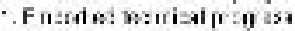

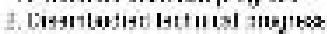

3. KL ralo

4. =Lh is $g: 04$ roch $1:$ I: $q$ i

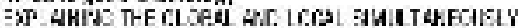

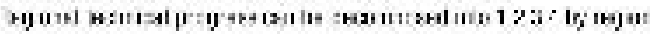

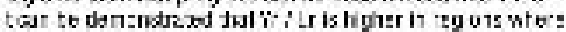

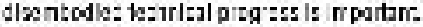

Wietame the mi os reisalois:

\section{Theorlas of the wellara strita}

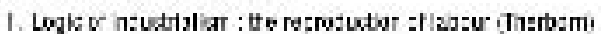

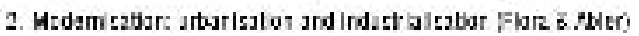

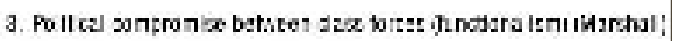

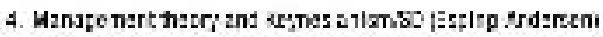

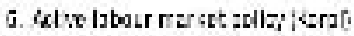

G. D:m esaron es require with states Itamerom

7. Sodel sartrd Froc 8 Conzrdi

8. Contad cloos igeuat:

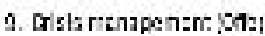

\section{Thesges to the weilare itale in , glatesteam work}

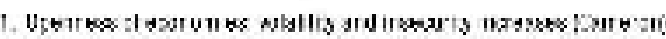

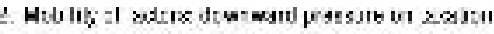

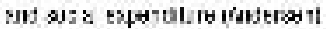

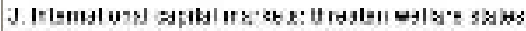

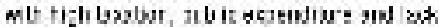

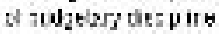

\section{a. Welfara states ant the glots}

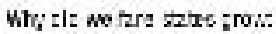

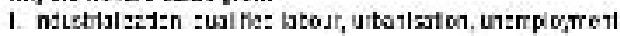

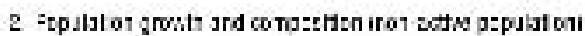

3. 4af 01 care and a:IH:s

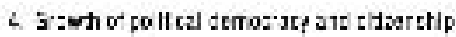

$\mathrm{T}: ; \mathrm{i}: \mathrm{bo}$

1. Tatbes the cta'2cistalas ot in:ustaliaden

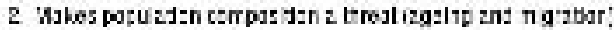

3 stdatts tha 12tbar stable

4 'Askespolba son:lkaxod: na zlabar tezasen pal dal urd exitanc aswar

Troulugy of whisne etghes

\begin{tabular}{|c|c|c|}
\hline & Unmenesiet & MeIrances hyest \\
\hline Migh previsum & 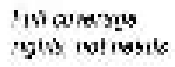 & 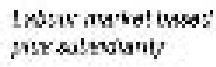 \\
\hline Lam snroksinn & 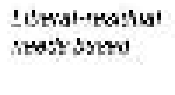 & 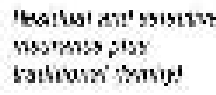 \\
\hline
\end{tabular}

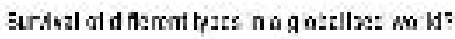

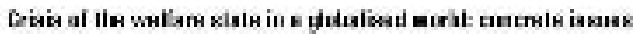

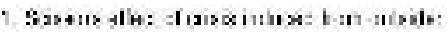
Һу

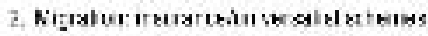

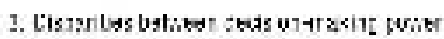

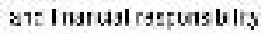

4. The ro e of li2d bare satiat; in the una:

5. Partab is; at scten:s 


\begin{tabular}{|c|c|c|}
\hline \multicolumn{3}{|c|}{ [xpenditure ses 's of buP [19:1-k7] } \\
\hline & Sodzl & Puslc \\
\hline Fapim & 28 & 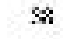 \\
\hline Dilatis & 1 19 & ה \\
\hline Dgrma'k. & $z 2$ & 47 \\
\hline Frat: & 20 & 42 \\
\hline Asmo $1 \%$ & 28 & s \\
\hline taln! & $1: 3$ & 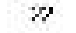 \\
\hline Sertot & $\boldsymbol{s i j}$ & so \\
\hline $\boldsymbol{X}$ & 17 & 36 \\
\hline נים & 17 & 2 \\
\hline
\end{tabular}

\section{Crisis of the watiare stala: olter vows}

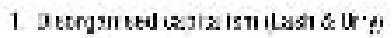

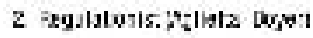

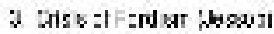

Alortajes aus:irtes

I Hao I bars t:riejles.:n 2a: nloodt

2 Hab t:rparajet fodith'g ard I3botr un oteI

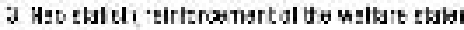
File of itutil te

\section{Policies}

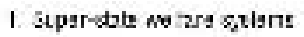

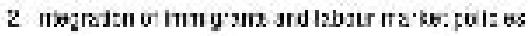

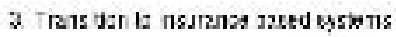

2 a)

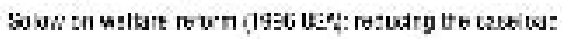

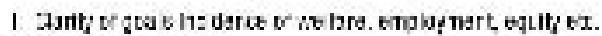

2 ¿*3li2j:n ressundi

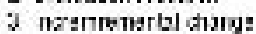

2 Warta's redpiems repord te nartios

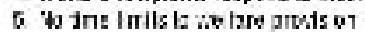




\title{
O TEMPORAL DE 3 A 6 DE DEZEMBRO DE 1739 EM PORTUGAL RECONSTITUIÇÃO A PARTIR DE FONTES DOCUMENTAIS DESCRITIVAS
}

\author{
Jõ̃o PAulo TABORdA ${ }^{1}$
}

\begin{abstract}
Resumo - As observações meteorológicas instrumentais, em Portugal, têm início nos anos 70 do século XVIII. O clima de Portugal anterior àquela década tem vindo a ser reconstituído exclusivamente com base em fontes documentais descritivas, em que, de um modo geral, são os extremos climáticos que surgem registados. Dada a subjectividade que este tipo de informação encerra, a análise crítica do maior número de fontes possível é um procedimento essencial. Analisa-se aqui o temporal ocorrido em grande parte do território de Portugal continental, entre 3 e 6 de Dezembro de 1739 . À violência do vento do quadrante Sul, que pelos efeitos relatados poderá ter atingido velocidades da ordem dos $120 \mathrm{~km} / \mathrm{h}$, associaram-se chuvas contínuas e intensas, que originaram cheias nas bacias dos rios Tejo, Mondego e Douro. Os prejuízos foram muito avultados, havendo referências à perda de vidas humanas e à morte de muitos animais. Tal como na actualidade, também no passado estes episódios de ventos fortes e de chuvas intensas ocorreram em situação de fluxo do quadrante Sul.
\end{abstract}

Palavras-chave: Climatologia histórica, fontes documentais descritivas, Portugal, século XVIII, fenómenos meteorológicos extremos.

\begin{abstract}
The weather in Portugal between 3 and 6 December 1739 (Based ON DESCRIPTIVE DOCUMENTAL SOURCES). Instrument-based meteorological observations in mainland Portugal started to be gathered in the 1770s. Weather in Portugal before that time can therefore only be reconstructed based on descriptive documental sources in which generally only extreme weather events are recorded. Due to the subjectivity of this type of information, critical analysis of the sources, their diversity and data crossing prove essential in order to be able to assess their trust-worthiness. Here we have chosen to analyse a gale that swept across much of mainland Portugal between 3 and 6 December 1739. The violent winds coming from the South, which according to reports may have reached speeds of $120 \mathrm{~km} / \mathrm{h}$, were accompanied by heavy, continuous rain that produced flooding in the basins of the rivers Tagus, Mondego and Douro. Large-scale damage would have occurred, backed up by references to the death of many animals and the loss of human lives. As nowadays, these storm events were originated from winds coming from the South.
\end{abstract}

1 Professor de Geografia, Escola Secundária Gabriel Pereira, Évora. E-mail: joaotaborda@hotmail.com 
Key words: Historical climatology, descriptive documental sources, Portugal, $18^{\text {th }}$ century, extreme meteorological phenomena.

Résumé - TENTATIVE DE RECONSTITUTION DE LA TEMPÊTE DU 3 AU 6 DÉCEMBRE 1739 AU PORTUGAL. Les reconstitutions climatiques antérieures aux années $70 \mathrm{du}$ XVIII ${ }^{\text {ème }}$ siècle ne peuvent s'appuyer au Portugal que sur des sources documentaires descriptives, lesquelles enregistrent surtout les situations extrêmes. D'où l'importance de l'analyse critique et du croisement de sources si possible multiples. La tempête qui a sévi sur la plus grande partie du Portugal, du 3 au 6 décembre 1739, était associée à des vents du secteur Sud, qui, à en juger par leurs effets, ont dû atteindre quelque $120 \mathrm{~km} / \mathrm{h}$, et à des pluies continues et intenses, qui ont provoqué des inondations dans les bassins du Tage, du Mondego et du Douro. La mort de nombreux animaux et de quelques personnes a été enregistrée. Comme actuellement, ces tempêtes étaient associées à des vents du secteur Sud.

Mots clés: Climatologie historique, sources documentaires descriptives, Portugal, XVIIIème siècle, phénomènes météorologiques extrêmes.

\section{INTRODUÇÃO}

A discussão acerca das alterações climáticas e do impacto das actividades humanas no clima originou, nas últimas décadas do século $\mathrm{XX}$, um incremento dos estudos em Climatologia Histórica na Europa, com uma intensificação da cooperação internacional e um aumento expressivo quer dos estudos publicados, quer do número de especialistas e de equipas desenvolvendo investigação neste domínio.

Em Portugal, contudo, para além da inventariação realizada por Ferreira (1944) sobre as observações meteorológicas anteriores à fundação do Observatório do Infante D. Luís, nenhuma pesquisa sistemática em Climatologia Histórica havia sido feita antes da participação de um grupo de investigadores portugueses no projecto europeu ADVICE (Annual to Decadal Variability in Climate in Europe). No âmbito desse projecto, que decorreu entre 1996 e 1998, foram publicados vários trabalhos (Alcoforado, 1999; Alcoforado et al., 1997; Alcoforado et al., 1999; Alcoforado et al., 2000; Barriendos et al., 1997 e Nunes, 1997). À margem do projecto ADVICE, importa referir o estudo de Daveau (1997) sobre os tipos de tempo em Coimbra (Dez. 1663/Set. 1665) e a inventariação de Marques (2001/02) sobre os estados de tempo em Braga, no século XVIII. Mais recentemente, Taborda et al. (2004) estenderam a reconstituição do clima do Sul de Portugal a todo o século XVIII.

As primeiras observações meteorológicas instrumentais realizadas em Portugal são tardias (últimas três décadas do século XVIII, em particular os anos 80), quando comparadas às efectuadas em outros países da Europa (Inglaterra e França, por exemplo). Na ausência de informação meteorológica numérica, o estudo do clima de Portugal anterior àquele período tem vindo a ser baseado noutro género de informação, nomeadamente a recolhida em fontes documentais descritivas, as quais já se revelaram de grande utilidade na reconstituição do clima em Portugal, nomeadamente durante o último quartel de Seiscentos e no século XVIII (Alcoforado et al., 2000; Taborda et al. 2004).

De um modo geral, os excessos climáticos (secas prolongadas, violentos ou continuados episódios pluviométricos, calores extremos ou inusitadas quedas de neve) são 
potenciais geradores de registos (Nunes, 1997). A escassez ou inexistência de notícias relativas ao tempo e aos fenómenos meteorológicos podem ser interpretadas como reveladoras da fraca frequência ou ausência de situações extremas, mas também se podem ficar a dever a uma falta de interesse na anotação desse tipo de acontecimentos (Camuffo e Enzi, 1991). Deste modo, não se pode concluir, com inteira segurança, que todos os períodos para os quais se não dispõe de informação sejam forçosamente "normais", isto é, caracterizados pela ausência de anomalias meteorológicas (Alcoforado et al., 1999).

\section{DOCUMENTOS E MÉTODOS}

O estudo, que aqui se apresenta, assenta exclusivamente em informação de natureza qualitativa, proveniente de um conjunto diversificado de fontes, quer institucionais (particularmente eclesiásticas), quer de iniciativa individual (como as memórias ou as "Relações"), quer ainda de periódicos da época (manuscritos e impressos). De um modo geral, trata-se de assentamentos efectuados por pessoas letradas, mas que não revelam interesse pelo clima ou pela meteorologia para além da simples curiosidade ou da preocupação com as suas implicações na vida quotidiana das populações, por exemplo, impossibilitando a realização de cerimónias religiosas, condicionando a transitabilidade dos caminhos e atrasando a chegada do correio, provocando prejuízos materiais e a perda de vidas humanas ou, ainda, comprometendo o desenvolvimento das culturas agrícolas.

A utilização deste género de informação impõe cuidados muito particulares. Assim, o exame das fontes é um procedimento indispensável a uma avaliação da fiabilidade das notícias, devendo começar-se pela pesquisa biográfica sobre os seus autores (Pavese et al., 1995). Os testes críticos mais importantes baseiam-se nos princípios da contemporaneidade e proximidade temporal e espacial; os testemunhos registados não podem ser considerados de confiança e válidos, a não ser que se demonstre que o seu autor viveu próximo, quer no tempo, quer no espaço, dos acontecimentos que descreve, que registou as suas observações imediatamente ou dentro de um curto período de tempo após essas ocorrências ou que teve acesso em primeira mão ao relato escrito ou oral dos acontecimentos, sendo a partir deles que rigorosamente transmite a informação (Ingram et al., 1978).

A maior parte dos autores utilizados neste estudo, já em anteriores trabalhos (Alcoforado et al., 2000 e Taborda et al., 2004) foram criteriosamente analisados e as suas credibilidade e fiabilidade examinadas numa perspectiva de crítica das fontes. Tal é o caso do Padre Luiz Montez Mattozo (1701-1750), do Padre João Baptista de Castro (1700-1775?), de Frei Francisco José de Oliveira (1707-174?), entre outros. Também a documentação de natureza institucional como os livros dos "Acordos do Cabido" da Sé de Évora e os periódicos da época, quer manuscritos ("Diario"), quer impressos ("Gazeta de Lisboa"), se revelaram, uma vez mais, importantes na reconstituição de eventos meteorológicos com carácter extremo, como o que agora se estuda. Todavia, importa destacar aqui, pela natureza e características dos seus testemunhos, os nomes de Manoel José Correa e Alvarenga e de Martinho Lopes de Morais Alão.

Alvarenga nasceu em Braga, no ano de 1717, tendo falecido na segunda metade do século XVIII. Estudou Gramática e Filosofia no Colégio dos Jesuítas daquela cidade e Teologia no Colégio dos Eremitas de Santo Agostinho. Na Universidade de Coimbra recebeu o grau de Mestre em Artes e a formatura nos Sagrados Cânones (Machado, 1752, tomo III; Silva, 1893, tomo XVI). É da sua autoria a "Relaçaõ dos Estragos, Que 
desde o dia 3. de Dezembro athe 6 do mesmo mez do prezente anno de 1739. infelizmente cauzou nesta Cidade de Coimbra huma sempre memoranda Tempestade", impressa em Coimbra, no Real Collegio das Artes da Companhia de Jesus, no ano de $1740^{2}$. Esta "Relaçaõ" parece assentar num testemunho vivido e, de acordo com o título, terá sido composta em Coimbra ainda em Dezembro de 1739, ou seja, poucos dias após o evento meteorológico em estudo ter ocorrido. Tais factos conferem autenticidade e credibilidade às palavras de Alvarenga, uma vez que afastam a suspeição de se tratar, quer da adaptação pela sua pena de uma descrição ouvida a terceiros, quer de algo ocorrido num passado mais ou menos afastado e, como tal, já de contornos diluídos pelo tempo. Confere a esta descrição meteorológica um sabor muito particular o ter sido escrita sob a forma de poema, dividido em trinta e nove oitavas, tantas quantos os anos que então eram decorridos do século XVIII.

Alão nasceu na cidade do Porto em 1713, e era já falecido em 1789 (Silva, 1862, tomo VI). Depois de estudar as ciências escolásticas, obteve um Canonicato na catedral da sua cidade. Desde os primeiros anos cultivou a poesia que, na opinião de um seu contemporâneo (Machado, 1752, tomo III: 434) "exercita com felicidade, como tambem a Oratoria que se admira nos seus Discursos, e Cartas". Alão descreve o estado de tempo que aqui se estuda em o "Sucesso lamentavel da destruiçam do Porto, e seus suburbios acontecido no fatal mez de Dezembro de 1739 offerecido à Venerável Prodigioza, e Sacrosanta imagem do Senhor D'Alem. Venerada na Santa Igreja Cathedral da mesma cidade por hum cordialíssimo devoto deste Senhor", obra em setenta e sete oitavas, impressa no Porto, no ano de 1740. Estrofe a estrofe, vão-se sucedendo as referências às diversas ocorrências, que caracterizaram o estado do tempo no Porto durante aqueles dias, bem como às suas consequências.

Uma vez que os observadores baseiam as anotações e comentários sobre o tempo e o clima nas suas próprias experiências (Jones e Bradley, 1995), a informação utilizada encerra sempre um grau, maior ou menor, de subjectividade. Neste sentido, revela-se de uma extrema importância a diversificação de fontes, uma vez que, desse modo, o cruzamento de informação permite, não só avaliar a fiabilidade dos dados e a credibilidade que cada autor deve merecer, como também eliminar erros, eventuais exageros, desfazer dúvidas decorrentes de relatos mais dúbios e, assim, minimizar a subjectividade inerente a este tipo de documentação (Camuffo e Enzi, 1995; Rodrigo et al., 2001). Brázdil (2000) confere idêntico valor ao cruzamento dos dados, quer se trate de um cruzamento espacial, aquele que permite confirmar uma certa extensão territorial de determinado fenómeno atmosférico, quer factual, ou seja, o que comprova a ocorrência de uma situação meteorológica num lugar, através do testemunho de várias fontes.

No total são catorze as fontes que dão testemunho das severas condições meteorológicas que atingiram Portugal continental na primeira semana de Dezembro de 1739. A existência de notícias relativas a sete diferentes locais permite, assim, apreciar a extensão espacial do evento meteorológico, enquanto a existência de mais do que uma fonte para cada um dos locais (à excepção de Montemor-o-Novo e de Cuba) é um indicador da sua fiabilidade (quadro I).

2 No "Index dos Papeis", contidos no volume onde se encontra esta "Relação", há referência a um outro intitulado "Guerra dos Elementos, Ar, Fogo, e Agoa, feita â terra, em Coimbra, e seus Campos em Dezr. ${ }^{\circ}$ de 1739", da autoria de Manuel Nunez da Silva. Infelizmente, deste "Papel" mais não restaram do que vestígios das suas folhas. 
Quadro I - Locais, informações e número de fontes disponíveis

Table I - Places, information and number of available sources

\begin{tabular}{lcccccc}
\hline & $\begin{array}{c}\text { Vento } \\
\text { Forte }\end{array}$ & Precipitação & $\begin{array}{c}\text { Saraiva } \\
\text { Trovoada }\end{array}$ & $\begin{array}{c}\text { Cheia } \\
\text { Inundação }\end{array}$ & Prejuízos & $\begin{array}{c}\text { N. }{ }^{o} \\
\text { de Fontes }\end{array}$ \\
\hline Porto & $\checkmark$ & $\checkmark$ & $\checkmark$ & $\checkmark$ & $\checkmark$ & 2 \\
\hline Coimbra & $\checkmark$ & $\checkmark$ & $\checkmark$ & $\checkmark$ & $\checkmark$ & 3 \\
\hline Santarém & $\checkmark$ & $\checkmark$ & & $\checkmark$ & $\checkmark$ & 2 \\
\hline Lisboa & $\checkmark$ & $\checkmark$ & & $\checkmark$ & $\checkmark$ & 4 \\
\hline Montemor-o-Novo & $\checkmark$ & & & & $\checkmark$ & 1 \\
\hline Évora & $\checkmark$ & $\checkmark$ & $\checkmark$ & & $\checkmark$ & 3 \\
\hline Cuba & $\checkmark$ & & & & & 1 \\
\hline
\end{tabular}

\section{O ESTADO DO TEMPO NO INÍCIO DE DEZEMBRO DE 1739. UMA SITUAÇÃO METEOROLÓGICA EXTREMA}

Entre 3 e 6 de Dezembro de 1739, o estado de tempo em Portugal continental terá sido particularmente severo, caracterizado pela violência do vento e por chuvas intensas. De acordo com os testemunhos disponíveis, estas condições atmosféricas terão afectado grande parte do território nacional, existindo informação para locais tão distintos como Cuba, Évora, Montemor-o-Novo, Lisboa, Santarém, Coimbra e o Porto (fig. 1). Segundo Marques (2001/2002), a tempestade terá igualmente assolado toda a província do Minho.

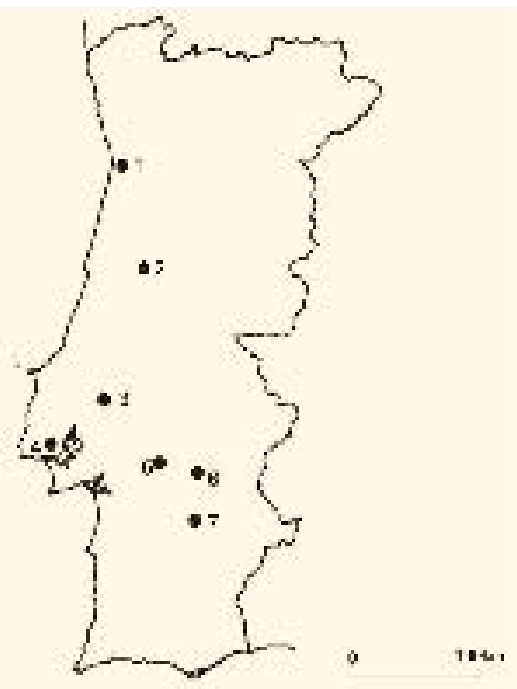

Fig. 1 - Locais com referências ao estado do tempo na 1. ${ }^{a}$ semana de Dezembro de 1739. 1. Porto; 2. Coimbra; 3. Santarém; 4. Lisboa; 5. Montemor-o-Novo; 6. Évora; 7. Cuba. Fig. 1 -Locations with references to the weather in the first week of December 1739. 1. Oporto; 2. Coimbra; 3. Santarém; 4. Lisbon; 5. Montemor-o-Novo; Evvora; 7. Cuba. 
Relativamente à força do vento, a par de expressões como "horroroso furacam"3 ou "calamitoza tempestade"4, surgem referências precisas aos seus efeitos e aos inúmeros prejuízos que terá provocado. Em Évora, é dito que o vento arrebatava os caminhantes (Costa, 1742), havendo alusões a casas destelhadas e a outras que caíram, bem como a inúmeras árvores arrancadas pela raiz, o que terá feito com que andasse gente, durante dois meses, a tirar lenha para a cidade (Fonseca, 2001). Em Montemor-o-Novo e no seu termo os prejuízos foram avaliados em 50000 cruzados (Costa, 1742). Também em Lisboa, a força do vento terá originado avultadas perdas, surgindo referências a ruínas em casas, a árvores arrancadas e a grandes estragos em muitas embarcações que se encontravam estacionadas no Tejo, vindo alguns navios dar à costa e naufragando outros. Segundo os relatos, terão perdido a vida muitas pessoas ${ }^{5}$. As condições meteorológicas em Santarém não terão sido muito diferentes, falando-se também em "tempestade de vento" ". O mau tempo terá igualmente afectado o centro norte e o norte do país. A propósito da violência do vento em Coimbra, escreve Alvarenga (1740) o seguinte, nos quatro primeiros versos da décima segunda oitava do seu poema:

\section{Cada vez mais os ventos dezabridos \\ Universaes ruinas vaõ causando, De huma para outra parte compellidos, Edificios, e cazas devastando.}

No Porto, a situação terá sido semelhante, pois Alão (1740) referindo-se ao vento escreve nos dois primeiros versos da nona oitava da sua obra:

\section{Arvores arrancava furiozo, E cazas derrubava embravecido}

Quanto à direcção do vento, existem duas fontes para Lisboa que fazem referência a vento de Sul. Uma diz, aludindo à tempestade: "[...] impellida vigorosamente do vento Sul, que dominava embravecido [...]" (Costa, 1742). Na outra pode ler-se: "Os ventos que havia muito tempo reinavam da parte do Sul, tomáram tanta força [...]"7 . Com esta indicação, são consentâneas outras que dão conta de algumas naus de guerra, estacionadas no porto de Lisboa, terem ido parar a Sacavém, ao Montijo e a Alcochete (naturalmente impelidas pela força do vento). Também no Porto terão sido do quadrante Sul os ventos tempestuosos, pois Alão (1740), já na septuagésima oitava, versos dois a quatro, ao referir-se à melhoria das condições atmosféricas diz:

\section{E mudados do Sul ao Norte os ventos \\ Logo de improvizo em hum instante \\ Amnistia fizeraõ os elementos.}

3 “Gazeta de Lisboa", n. ${ }^{\circ}$ 50: 600.

4 B.C.M.C., "Memórias Históricas do Lugar de Cuba", de Frei Francisco de Oliveira, fl. 22.

5 B.P.E., cod. CIV/1-8 d. "Diario", de 8 de Dezembro de 1739, fl. 163; Costa (1742); "Gazeta de Lisboa", n. ${ }^{\circ}$ 50: 600 e Fonseca (2001).

6 B.P.E., [Mattozo (1738)], cod. CIII/2-5: f.100 e cod. CIV/1-25 d.: fl.n.n.

7 "Gazeta de Lisboa", n. ${ }^{\circ}$ 50: 600. 
Para além da violência do vento, o estado do tempo durante os primeiros dias de Dezembro de 1739 caracterizou-se por intensa precipitação. Em Évora, em virtude da "grande abundância de chuva" a procissão da Aclamação de D. João IV (1. ${ }^{\circ}$ de Dezembro) não se realizou senão por dentro da igreja e pelos claustros ${ }^{8}$. Nos dias 4 e 5 a chuva terá sido particularmente intensa ("tempestade de agoa" é a expressão utilizada) e acompanhada no primeiro (dia de Santa Barbara!) por forte trovoada (Fonseca, 2001).

O "Diario" de 8 de Dezembro dá conta de contínuas chuvas em Lisboa e de grandes inundações que "retardaõ correyos e paquebotes" impedindo a chegada de novidades à capital. No Ribatejo, a situação terá sido idêntica: "A 2 de Dez. ${ }^{\circ}$ destte anno de 1739 principiou a chover $\mathrm{m} .^{\text {ta }}$ agoa, a trez $\mathrm{q}$ foi $5^{\mathrm{a}} \mathrm{fr}^{\mathrm{a}}{ }^{\mathrm{a}}$ se vio encher o Tejo $\mathrm{m} .^{\text {to }}$, e na $6{ }^{\mathrm{a}}$ f. ${ }^{\text {ra }}$ q. ${ }^{\mathrm{e}}$ se contarão 4 . foy huma chea tão grande q. ${ }^{\mathrm{e}}$ havia mais de 40 annos não fora outra igual [... "'9 . Tal como em Évora, também em Santarém o paroxismo do mau tempo deverá ter sido atingido nos dias 4 e 5, pois é referido que os "[...] Rios encherão em hua noyte tão Repentinam. ${ }^{\text {te }} \mathrm{q}$ deytarão fora em poucas horas [...]" ${ }^{10}$. A acumulação de precipitação em Novembro, que se deduz de notícias que aludem a tempo chuvoso, nomeadamente a um "terrivel dia em que choveu 15 horas sem cessar" e, já então, a cheias no Tejo ${ }^{11}$, terá potenciado as inundações dos primeiros dias de Dezembro. Como consequência, há registo de avultados prejuízos, da perda de numerosas alfaias agrícolas e de muitas casas alagadas. As fontes dão igualmente conta da perda de vidas humanas e do afogamento de inúmeras cabeças de gado.

Em Coimbra verificaram-se também chuvas abundantes. Delas dão testemunho expressões como "tam grosso chuveiro", "Da chuva, que continua se augmentava", ou "E tal chuva impossivel ser podia, / So se todo o Oceáno se esgotasse" (Alvarenga, 1740). Ainda que originadas também pela violência do vento, como já foi dito, parece ser contudo da abundante e contínua precipitação e das consequentes cheias e inundações do Mondego e seus afluentes que terão resultado a maior parte dos danos e das vítimas em Coimbra e seus arredores. Assim, na vigésima terceira oitava e nos primeiros quatro versos da vigésima oitava do poema, diz Alvarenga:

Da agoa faz o excesso, que parece

Qualquer regato hum mar com muito engano;

O soberbo Mondego se engrandece,

Prezumindo, que seja outro Oceano:

De seu natural curso já se esquece

Agora largo, túmido, e inhumano,

Querendo conservar a larga enchente,

Que a cazo lhe concede hum accidente.

Vay o Monda correndo arrebatado,

Aqui cazas, alli plantas quebrando,

Se a huns leva as alfayas desbocado,

Da mesma vida a outros vay privando.

8 A.C.S.E., CEC 14-VII, "Acordos do Cabido": fl. 316.

9 B.P.E., Mattozo (1738), cod. CIV/1-25 d.: fl. n. n.

10 B.P.E., Mattozo (1738), cod. CIII/2-5: fl. 100.

11 B.P.E., cod. CIV/1-8 d. "Diário", de 24 Novembro de 1739: fl. n. n. 
Devem, pois, ter sido avultadas as perdas causadas, tanto pela força da corrente e pela carga sólida transportada (que foram, inclusive, responsáveis pela destruição da ponte sobre o Mondego), como pelas inundações. As águas terão provocado estragos na Cerca de S. Bento e nas paredes da Quinta dos Jesuítas, tendo entrado em Coimbra, invadido a sua baixa e chegado a Santa Cruz, "Formando com pasmozas maravilhas / Das ruas largo mar, das cazas ilhas" (Alvarenga, 1740).

No Porto, os danos terão atingido proporções semelhantes. As muitas chuvas conduziram ao aumento do caudal do rio Douro que, devido à subida do nível das águas e ao ímpeto da sua corrente, provocou volumosos estragos, sendo muitos os navios que naufragaram. A vigésima primeira e a vigésima quarta oitavas do poema de Alão (1740) dão bem conta do grau de destruição verificado:

Corria o Douro taõ arrebatado, Taõ rápido, cruel, e tã̃ valente, Que parecia vinha declarado Inimigo de todo o ser vivente: Tudo deixava o Douro destroçado, Tudo despedaçava a sua enchente, E entaõ na fortaleza, e valentia Mais que o Douro, de bronze parecia.
Tonéis, arvores, pipas, e telhados Trazia em si o Douro furiozo, Que os lugares vizinhos asolados Deixava este ladrão facinorozo: Olhavaõ os viventes lastimados Para o Douro na enchente caudalozo, E viaõ por dobrar as suas magoas Nelle mais os destroços, do que as agoas

Na margem sul, em "Vila nova" (de Gaia), as perdas foram também consideráveis, com as águas do Douro a entrarem nos armazéns de vinho.

De acordo com Daveau et al. (1978: 241), “A cheia de 5 de Dezembro de 1739 é a maior ainda hoje lembrada. As águas atingiram então um nível que cobriria o tabuleiro inferior da ponte D. Luís, construída em 1881".

Mas o rigor das condições atmosféricas, particularmente a chuva intensa, não terá afectado apenas a fachada ocidental da Península Ibérica. De Espanha, mais concretamente da Andaluzia e de Murcia, surgem também notícias de mau tempo durante a primeira semana de Dezembro de 1739 (informação oral de Mariano Barriendos). Em Sevilha, grandes chuvadas no dia 3 de Dezembro originaram cheias no rio Guadalquivir, que se prolongaram até ao dia 6 . A inundação terá sido importante, mas as fontes documentais não fazem referência a prejuízos. Em Murcia, entre 5 e 10 de Dezembro, ocorreram inundações. Um importante canal (Aljufia) sofreu estragos. Os moinhos de água foram desactivados e as pessoas encerraram as suas instalações para evitar maiores prejuízos.

\section{PROVÁVEL ENQUADRAMENO SINÓPTICO}

A informação disponível é insuficiente para reconstituir a evolução do quadro sinóptico que esteve na origem do estado do tempo na primeira semana de Dezembro de 1739. No entanto, parece evidente que a forte instabilidade atmosférica, que se deduz dos diversos testemunhos, terá resultado de uma circulação caracterizada por uma acentuada vorticidade e um forte gradiente horizontal da pressão atmosférica. Na opinião de M. Costa Alves ${ }^{12}$ (informação oral), atendendo aos relatos dos prejuízos

12 Meteorologista. Director do Centro de Coordenação Regional de Castelo Branco do Instituto de Meteorologia. 
causados pela força do vento, ter-se-ão verificado rajadas médias máximas superiores a $120 \mathrm{~km} / \mathrm{h}$.

Dos séculos XVII e XVIII chegam-nos notícias de várias outras situações tempestuosas em Portugal como, por exemplo, as de início de Dezembro dos anos de 1600 e de 1639, ou as de 19 de Novembro de 1724 e de 15 de Outubro de 1732. Todas, quer pela extensão de território atingido, pela violência do vento, quer ainda pelo volume dos prejuízos e o número de vítimas que são reportados, parecem poder equiparar-se à de Dezembro de 1739. De acordo com as descrições disponíveis, as duas últimas estiveram também associadas a ventos do quadrante Sul, existindo, no que se refere à tormenta que assolou Portugal continental a 19 de Novembro de 1724, notícias do que deverá ter sido a sua passagem, no dia anterior, pela Ilha da Madeira e dos grandes estragos que provocou em locais como o Funchal, Santa Cruz, Machico, entre outros ${ }^{13}$. Ainda no século XVIII, mas já na década de 80 , tanto as notícias da imprensa, como os registos das observações meteorológicas instrumentais realizadas por Joaquim da Assumpção Velho e Jacob Crysostomo Pretorius, na região de Lisboa, revelam, também, a ocorrência de condições meteorológicas severas, bem como a sua relação com ventos do quadrante Sul (Taborda et al., 2004).

A tempestade dos primeiros dias de Dezembro de 1739 parece, igualmente, encontrar paralelo nalguns episódios de ventos fortes sucedidos no século XIX, XX e início do presente. Pela severidade das condições atmosféricas e pela extensão e gravidade dos danos, são de destacar as situações de 15 de Fevereiro de 1941, "o dia do ciclone" - como por antonomásia ficou conhecido, provavelmente um dos fenómenos meteorológicos com consequências mais graves verificados em Portugal no século passado e, mais recentemente, o evento do fim de Dezembro de 1981. Mas outras situações de ventos fortes têm ocorrido, nomeadamente na faixa litoral, algumas das quais com efeitos igualmente gravosos sobre a natureza e a integridade e segurança de vidas e bens (Capello, 1865; 1883; Daveau et al., 1978; Carvalho et al., 1991; Lopes, 2003).

$\mathrm{Na}$ actualidade, a ocorrência de ventos fortes, na região costeira de Portugal continental, está associada, quer a sistemas quase estacionários, quer à aproximação e passagem de perturbações, tais como depressões e superfícies frontais (Carvalho et al., 1991).

Pela violência do vento, que fustigou o país de Norte a Sul, o cenário de destruição do dia 15 de Fevereiro de 1941, tal como o noticiou a imprensa, atingiu proporções de verdadeira tragédia: milhares de árvores arrancadas, estradas intransitáveis, casas destelhadas, reduzidas a montões de destroços, chaminés ruídas, famílias sem abrigo, povoações isoladas, a rede eléctrica destruída e as ligações telegráficas e telefónicas interrompidas, sementeiras perdidas e... uma centena de mortos e dezenas de feridos e desaparecidos, nomeadamente em áreas costeiras e ribeirinhas, onde a ocorrência de naufrágios foi enorme. De acordo com as declarações de Amorim Ferreira a "O Século" (16 de Fevereiro de 1941), nunca uma tormenta havia sido tão violenta

13 "Gazeta de Lisboa", n. ${ }^{\circ}$ 17: 136. Recorde-se as excepcionais cheias, de consequências catastróficas, que ocorreram na região de Lisboa entre 25 e 26 de Novembro de 1967, resultantes de quedas pluviométricas elevadas também "associadas a um sistema depressionário formado na região do arquipélago da Madeira e que, desde 24 de Novembro, se começou a deslocar para Nordeste, em direcção a Lisboa (Amaral, 1968: 79). Mais recentemente, a 10 de Outubro de 2005, o ciclone extratropical Vince percorreu a distância que separa o arquipélago da Madeira do Sul de Portugal continental em cerca de 24 horas (http://www.eumetsat.int/). 
desde 1854, ano em que foi fundado o Observatório Meteorológico do Infante D. Luís: "Só em 10 de Março de 1895 o barógrafo registou 722mm (962hPa) de pressão, acompanhada de um temporal, que também atingiu extraordinária violência, mas que não se compara com este". No dia 15 de Fevereiro de 1941, os valores da pressão atmosférica desceram até $937 \mathrm{hPa}$ em Coimbra, $950 \mathrm{hPa}$ em Lisboa/Geofísico e $931 \mathrm{hPa}$ em Évora. O vento máximo instantâneo foi de $133 \mathrm{~km} / \mathrm{h}$ em Coimbra e de $129 \mathrm{~km} / \mathrm{h}$ em Lisboa. Segundo M. Costa Alves (informação oral) tratou-se de uma perturbação extrema isolada, com trajectória pela Estremadura e que, em comparação com a situação de Dezembro de 1739, gerou valores de precipitação relativamente modestos (16.5mm em Lisboa).

Entre 26 e 31 de Dezembro de 1981, Portugal foi assolado por um temporal, que teve o seu paroxismo nos dias 29 e 30: "Do Minho ao Algarve, chuvadas de grande intensidade e rajadas de vento ciclónico - que chegaram a atingir 120 quilómetros horários - causaram prejuízos de valor ainda incalculado e perturbaram a normalidade de todas as actividades [...] as comunicações ferroviárias estão interrompidas em vários locais do País [...] Há centenas de árvores e postes telefónicos e condutores de energia derrubados pela ventania, quase todos os portos do País estão fechados à navegação [...]" ("Diário de Notícias" de 31 de Dezembro de 1981). Aos estragos resultantes da violência do vento acrescentaram-se os danos provocados pelas cheias nas bacias dos rios Tejo, Mondego, Douro e Lima. No total, houve a lamentar a perda de trinta vidas humanas.

Destes dois episódios de ventos fortes ocorridos no século passado, o primeiro tem semelhanças com o evento de 1739 essencialmente se atendermos à violência do vento. Todavia, distingue-se dele, quer porque foi acompanhado de quantitativos pluviométricos modestos, quer pela sua duração, que se circunscreveu a um dia.

Relativamente à situação de final de Dezembro de 1981, embora a pressão atmosférica não tivesse descido aos valores registados em 15 de Fevereiro de 1941 (em Coimbra, Lisboa/Portela e Évora os valores mais baixos, ocorridos no dia 30 de Dezembro, foram de, respectivamente, $979 \mathrm{hPa}, 981 \mathrm{hPa}$ e $984 \mathrm{hPa}$ ) e a destruição provocada pelo vento não tivesse atingido as proporções de Fevereiro de 1941 ou de Dezembro de 1739, o mau tempo prolongou-se por vários dias e foi, também, caracterizado por chuvas intensas (na estação de Lisboa/Portela, por exemplo, entre os dias 26 e 30 de Dezembro de 1981, a precipitação chegou aos $157 \mathrm{~mm}$, quando a média do mês de Dezembro do período 1961/90 é de $96.8 \mathrm{~mm}$ ) e por ventos dominantes do quadrante Sul. Este cenário é muito semelhante ao ocorrido na primeira semana de Dezembro de 1739, pelo que importa analisar a evolução da situação sinóptica que enquadrou aquele episódio.

A circulação à superfície, durante os dias 26 a 30 de Dezembro de 1981, caracterizou-se pela progressão, à latitude de Portugal continental, de sucessivos sistemas frontais, associados a centros depressionários evoluindo à latitude de $50^{\circ} \mathrm{N}-55^{\circ} \mathrm{N}$. No dia 26, às 12 horas, a velocidade média do vento em Évora e em Coimbra foi de, respectivamente, $40 \mathrm{~km} / \mathrm{h}$ e $50 \mathrm{~km} / \mathrm{h}$. Nos dias 29 e 30 a situação agravou-se com a aproximação e passagem por Portugal de uma perturbação frontal associada a uma depressão muito cavada $(975 \mathrm{hPa})$. A carta de superfície das 00 horas de 30 de Dezembro (INMG), localizava-a imediatamente a Oeste da Galiza. O mau tempo atingiu então o seu paroxismo. Em Lisboa e em Évora, por exemplo, entre as 18 horas do dia 29 e as 18 horas do dia 30 a precipitação foi de, respectivamente, $58 \mathrm{~mm}$ e $33 \mathrm{~mm}$ e o vento atingiu velocidades médias de cerca de $60 \mathrm{~km} / \mathrm{h}$, isto é, superiores ao valor significa- 
tivo de $51 \mathrm{~km} / \mathrm{h}$, a partir do qual se verifica agitação total das árvores e se torna muito difícil andar contra o vento (Carvalho et al., 1991).

A circulação em altitude, entre os dias 26 a 30 de Dezembro de 1981, evoluiu do modo seguinte: após a migração para Leste de uma dorsal de eixo N-S, que no dia 25 se estendia da Península Ibérica até às Ilhas Britânicas, a situação passou a caracterizar-se pela presença, à latitude de Portugal continental, de um fluxo de Oeste, a norte do qual se manteve estacionário, a ocidente das Ilhas Britânicas, um centro de baixas pressões, expressão, aos diferentes níveis isobáricos $(700 \mathrm{hPa}, 500 \mathrm{hPa}$ e $300 \mathrm{hPa})$, dos núcleos depressionários localizados à superfície.

Apesar das dúvidas, parece provável que o quadro sinóptico que originou o temporal da primeira semana de Dezembro de 1739 tenha sido comparável ao dos últimos dias de 1981. São consentâneas com essa suposição as referências, em várias fontes, aos ventos do quadrante Sul e à sua persistência e, também, o facto das notícias provenientes de Espanha não mencionarem danos provocados pelo vento, o que faz supor que a fachada atlântica da Península Ibérica tenha sido a mais fustigada pelo mau tempo. Por outro lado, as alusões a mudanças de rumo do vento, em Coimbra (Alvarenga, 1740) e a ventos cruzados, em Évora (Costa, 1742), são também coerentes com as condições de grande turbulência características da passagem das perturbações frontais, nomeadamente dos seus ramos frios.

\section{CONSIDERAÇÕES FINAIS}

Nos últimos anos tem-se assistido, no âmbito do debate sobre o Aquecimento Global, a um aumento do interesse da comunidade científica e dos decisores políticos pelo estudo da frequência e intensidade dos fenómenos meteorológicos extremos. O projecto europeu MICE (Modelling the Impact of Climate Extremes) é representativo dessa atenção. Como vários autores têm vindo a reconhecer (Bradley e Jones, 1995; Jones et al., 2001), para um melhor entendimento dos mecanismos que regulam o comportamento da atmosfera e para a projecção do tipo de mudanças climáticas que poderão ocorrer no futuro, torna-se necessário melhorar o nosso conhecimento, quer acerca da componente natural da variabilidade climática, quer das variações do clima no passado. O reconhecimento, inventariação e caracterização de eventos meteorológicos extremos (secas, excessos hídricos, tempestades como a que aqui se analisa, ou outros), ocorridos antes da Era Industrial, revela-se, pois, de particular importância no contexto da actual discussão em torno do papel do Homem na alteração do funcionamento do sistema climático. O presente trabalho parece legitimar a conclusão de que em Portugal continental, tal como na actualidade, também no passado ocorreu uma forte relação entre as situações de temporal de vento e de chuvas intensas e os ventos do quadrante Sul.

As velocidades prováveis das rajadas máximas no caso de Dezembro de 1739 e as que foram medidas nos eventos de 1941 e 1981 (100-130km/h), ainda que excepcionais, nomeadamente na faixa litoral de Portugal continental (Carvalho et al., 1991), justificam que os episódios de ventos fortes, pela destruição que deixam atrás de si, sejam estudados de forma mais aprofundada. Assim, no futuro, a pesquisa sobre estas ocorrências no período anterior à criação da rede organizada de estações meteorológicas deve continuar, no sentido de se melhorar o conhecimento, quer da sua frequência e intensidade, duração e extensão espacial, quer do quadro sinóptico em que terão ocorrido no passado. 


\section{AGRADECIMENTOS}

Agradeço à Professora Doutora Suzanne Daveau e ao Professor Doutor João Carlos Garcia a leitura de versões anteriores deste texto. Agradeço ao Dr. Costa Alves, bem como ao Professor Mariano Barriendos, as informações orais facultadas, que permitiram enriquecer substancialmente esta nota. À Professora Doutora Maria João Alcoforado, devo um agradecimento muito especial pelas suas críticas e sugestões sempre estimulantes, e por, numa tarde soalheira de Primavera, me ter falado do clima doutros tempos, apoiando-me e incentivando-me desde então na investigação que tento desenvolver no domínio da Climatologia Histórica.

\section{BIBLIOGRAFIA}

\section{FONTES MANUSCRITAS}

Arquivo do Cabido da Sé de Évora (A.C.S.E.)

Codices Eborensis Capituli (CEC), Acordos do Cabido, Livro 35 (1714-1744), CEC 14-VII.

Biblioteca da Câmara Municipal de Cuba (B.C.M.C.)

Oliveira, Frei F J de (1742) Memórias Históricas do Lugar de Cuba. Cópia tirada fielmente do Codice 104 da Bibliotheca Municipal Portuense por Pedro Augusto Ferreira Bacharel formado em Theologia, Cavalleiro da Ordem de Nossa Senhora da Conceição de Villa Viçosa Abbade de Miragaya, no Porto, em 1882.

\section{Biblioteca Pública de Évora (B.P.E.)}

Castro Pe J B de (1750) Peculio VI. do P. ${ }^{e}$ Joam Bapt. ${ }^{a}$ de Castro Sacerdote Lisbonense Na. 1750. Reservados, cod. CXII/2-6.

Castro $\mathrm{P}^{\mathrm{e}} \mathrm{J} \mathrm{B}$ de (1766) Opusculos de erudiçam mixta sobre assumpto Geografico, Cronologico, e Filológico [...]. Opusculo 2. ${ }^{\circ}$ Chronologico no qual se dâ breve not. ${ }^{a}$ dos sucessos mais memoraveis acontecidos em Portugal neste ultimo seculo de XVIII. Lix. ${ }^{a}$ An. de 1766. Reservados, cod. CXII/2-14.

Diario. Ano de 1739. Reservados, cod. CIV/1-8 d.

Mattozo Pe L M (1738) Memorias para a Historia Scalabitana, Chronologica, secular, e Ecclesiastica [...] Comecou esta obra a 13 de Fevereyro de 1738. em q.e sahiu o Sanctissimo Milagre. Tom.I. Santare Anno de 1738. Reservados, cod. CIII/2-5.

Mattozo $\mathrm{P}^{\mathrm{e}} \mathrm{L} \mathrm{M}$ (1738) Memorias recomendadas â estampa, para suprir os irreparaveis damnos, com que o tempo costuma consumir a memoria; Diario Historico das cousas q succedem, espicialmente nesta muyto nobre Villa de Santarem Por Luiz Montez Mattozo Scalabitanense Principiado no primeyro de Janeyro de 1738. conthem alguns succesos dos annos antecedentes, por não sepulta-los de todo o esquecimento. Santarem MDCCXXXVIII. Reservados, cod. CIV/1-25 d.

\section{FONTES IMPRESSAS}

Alão M L de M (1740) Sucesso lamentavel da destruiçam do Porto, e seus suburbios acontecido no fatal mez de Dezembro de 1739 [...]. Porto, anno de 1740 [em verso]: 27 p. 
Alvarenga M J C e (1740) Relação dos estragos, que desde o dia 3. de Dezembro athe 6 do mesmo mez do prezente anno de 1739 [...]. Coimbra, no Real Collegio das Artes da Companhia de Jesus, Anno de 1740: 15 p.

Costa V J da (1742) Prognostico novo do cometa, e mais impressoens metereologicas do anno 1737. até o presente de 1742 [...]. Lisboa. Na Officina de Miguel Rodrigues, Impressor do senhor Cardeal Patriarca, 1742: 28 p.

Diário de Notícias, de 31 de Dezembro de 1981.

Gazeta de Lisboa, n. ${ }^{\circ}$ 17, de 26 de Abril de 1725, e n. ${ }^{\circ}$ 50, de 10 de Dezembro de 1739.

O Século, de 16 de Fevereiro de 1941: 2.

\section{OBRAS DE REFERÊNCIA}

Alcoforado M J (1999) Variações climáticas do passado: chave para o entendimento do presente? Exemplo referente a Portugal (1675-1715). Territorium, 6: 19-30.

Alcoforado M J, Nunes M F, Garcia J C (1997) Climat et société à Lisbonne avant la mise en place institutionnelle des observations météorologiques. Publications de l'Association Internationale de Climatologie, 10: 75-83.

Alcoforado M J, Nunes F, Garcia J C, Taborda J P (2000) Temperature and precipitation reconstruction in southern Portugal during the late Maunder Minimum (AD 1675-1715). The Holocene, 10 (3): 333-340.

Alcoforado M J, Nunes M F, Garcia R (1999) A percepção da relação clima-saúde pública em Lisboa, no século XIX, através da obra de Marino Miguel Franzini. Revista Portuguesa de Saúde Pública, 1: 5-14.

Amaral I (1968) As inundações de 25/26 de Novembro de 1967 na região de Lisboa. FinisterraRevista Portuguesa de Geografia, III (5): 79-84.

Barriendos M, Garcia J, Martín-Vide J, Nunes F, Peña J C, Alcoforado M J (1997) $18^{\text {th. }}$ Century instrumental meteorological series in the Iberian Peninsula. General characteristics and climatic utility. Giuseppe Toaldo e il suo tempo. Scienze e lumi tra Veneto e Europa. Atti del Convegno, Padova: 907-920.

Bradley R S, Jones P D (eds) (1995) Climate Since A. D. 1500. Routledge, Londres: 706 p.

Brázdil R (2000) Historical climatology: definition, data, methods, results. Geografick_Casopis, 52 (2): 99-121.

Camuffo D, Enzi S (1995) Reconstructing the climate of northern Italy from archive sources. In Bradley R S, Jones P D (eds) Climate since AD 1500. Routledge, Londres: 143-154.

Camuffo D, Enzi S (1991) Locust invasion and climatic factors from the middle ages to 1800 . Theoretical and Applied Climatology, 43: 43-73.

Capello J C de B (1883) Barometrical depressions between the Azores and the continent of Europe. Quarterly Journal of the Meteorological Society, IX, 46: 115-117.

Capello J C de B (1865) Temporal de 13 de Dezembro de 1864. Imprensa Nacional, Lisboa: 5 p.

Carvalho R A C, Prior V M S, Lamelas H (1991) Vento forte nas regiões costeiras de Portugal: frequência, duração e suas causas. Comunicação apresentada ao Seminário: A zona costeira e os problemas ambientais. EUROCAST. Universidade de Aveiro, 18, 19 e 20 de Setembro de 1991: 184-210. 
Daveau S (1997) Os tipos de tempo em Coimbra (Dez. 1663/Set. 1665), nas cartas do Padre António Vieira. Finisterra - Revista Portuguesa de Geografia, XXXII(64): 109-115.

Daveau S, Almeida G, Feio M, Rebelo F, Silva R, Sobrinho A (1978) Os temporais de Fevereiro/Março de 1978. Finisterra - Revista Portuguesa de Geografia, XIII(26): 236-260.

Ferreira H A (1944) Observações meteorológicas em Portugal antes da fundação do Observatório do Infante D. Luís. Separata das Memórias da Academia das Ciências de Lisboa, Classe de Ciências, tomo IV. Lisboa: 13 p.

Fonseca T (2001) Triste e Alegre Cidade de Évora. Testemunho de um anónimo do século XVIII. Estudo e transcrição. Colecção "Novos estudos Eborenses" - 5. C.M.E., Évora: 104 p.

Ingram M J, Farmer G, Wigley T M L (1978) Historical Climatology. Nature, 276: 329-334.

Jones P D, Bradley R S (1995) Climatic variations over the last 500 years. In Bradley R S, Jones P D (eds) Climate since AD 1500. Routledge, Londres: 649-665.

Jones P D, Ogilvie A E J, Davies T D, Briffa K R (2001) Unlocking the doors to the past: recent developments in climate and climate impact research. In Jones P D, Ogilvie A E J, Davies T D, Briffa K R (eds) History and Climate. Memories of the Future? Kluwer Academic/Plenum Publishers, Nova Iorque: 1-8.

Lopes A (2003) Modificações no clima de Lisboa como consequência do crescimento urbano. Vento, ilha de calor de superfície e balanço energético. Tese de doutoramento em Geografia Física apresentada à Faculdade de Letras da Universidade de Lisboa. Lisboa: 360 p.

Machado D B (1741/1759) Bibliotheca Lusitana Histórica, Critica, e Cronologica [...], ed. facsim., $2^{\mathrm{a}}$ ed., 4 tomos. Lisboa: 1930-1935.

Marques J (2001/2002) Estados do tempo e outros fenómenos, na região de Braga, no século XVIII. Bracara Augusta. Revista Cultural da Câmara Municipal de Braga. vol. L, n. ${ }^{\circ}$ 104-105 (117-118): 97-194.

Nunes M F (1997) As observações meteorológicas na Academia das Ciências: uma leitura científica de Lamego (1770-1784). Alcipes e as Luzes. Fundação das Casas de Fronteira e Alorna, Lisboa: $12 \mathrm{p}$.

Pavese M P, Banzon V, Colacino M, Gregori G P, Pasqua M (1995) Three historical data series on floods and anomalous climatic events in Italy. In Bradley R S, Jones P D (eds.) Climate since $A D$ 1500. Routledge, Londres: 155-170.

Rodrigo F S, Pozo-Vázquez D, Esteban-Parra M J, Castro-Diez Y (2001) A reconstruction of the winter North Atlantic Oscillation index back to A.D. 1501 using documentary data in southern Spain. Journal of Geophysical Research, 106, n. ${ }^{\circ}$ D14: 14,805-14,818.

Silva I F da, et al. (1858/1923) Diccionário Bibliographico Portuguez. Estudos de [...] aplicáveis a Portugal e ao Brasil continuados e ampliados por P. V. Brito Aranha. Revistos por Gomes de Brito e Álvaro Neves, $22+1$ tomos. Imprensa Nacional, Lisboa.

Taborda J P, Alcoforado M J, Garcia J C (2004) O Clima do Sul de Portugal no século XVIII. Reconstituição a partir de fontes descritivas e instrumentais. Área de Investigação de GeoEcologia, Relatório n. ${ }^{\circ}$ 2, Centro de Estudos Geográficos, Lisboa: 214 p. 


\title{
PASSADO E PRESENTE DA POLÍTICA DE GESTÃO DOS RECURSOS HÍDRICOS NO BRASIL
}

\author{
Antônio Augusto Rossotto Ioris ${ }^{1}$
}

\begin{abstract}
Resumo - Escassez hídrica, poluição dos rios e desiguais oportunidades de acesso à água são sintomas de um crescente antagonismo entre desenvolvimento económico e questões socioambientais no Brasil. Este progressivo afastamento entre economia e ambiente decorre de um processo mais amplo de acumulação de capital e inserção subordinada do país no mercado mundial. Reformas institucionais recentes vêm promovendo uma nova abordagem dos recursos hídricos através de instrumentos simuladores de mercado, como a cobrança pelo uso da água, para operacionalizar a gestão ambiental. Contudo, o novo modelo de gestão apenas reproduz a mesma lógica de mercantilização da natureza que foi historicamente responsável por criar uma situação de opressão política e degradação ambiental. Respostas efectivas aos problemas ambientais requerem mudanças nas relações de poder, no papel do Estado e na divisão internacional do trabalho.
\end{abstract}

Palavras-chave: Cobrança pelo uso da água, lei de recursos hídricos, gestão de bacia hidrográfica, justiça ambiental, Paraíba do Sul, Brasil.

\begin{abstract}
PAST AND PRESENT OF WATER RESOURCE MANAGEMENT POLICIES IN BRAzIL. Throughout the country's history, but particularly with the $20^{\text {th }}$ century's rapid industrialisation, economic development led to Brazilian society's gradual estrangement from the environment. Industrialisation called for a mode of production that exploits water and society as tools for the accumulation of capital. Escalating water scarcity and uneven access to water are symptomatic of this growing antagonism between society and nature. Recent legal and institutional changes have promoted a new approach to water management. One of the new policy instruments is charging for bulk water use in order to improve efficiency and recover investment costs. Charges on water have been supported by a strategic alliance between market forces and conservative environmentalists. However, in practice, the new management framework only reproduces the same previous rationale of water commodification that in the past generated serious socio-environmental distortions.
\end{abstract}

1 Engenheiro Agrónomo, MSc, ResDipl, PhD; Senior Policy Officer, Scottish Environment Protection Agency (SEPA), Erskine Court, Castle Business Park, Stirling, FK9 4TR, Escócia, Reino Unido. E-mail: antonio.ioris@sepa.org.uk 
Keywords: Charges for water use, water resource legislation, catchment management, environmental justice, Paraíba do Sul river basin, Brazil.

Résumé - LE PASSÉ ET LE PRÉSENT DE LA POLITIQUE DE GESTION DES RESSOURCES HYDRIQUES AU BRÉSIL. La rareté des ressources hydriques, la polution des rivières et les inégalités dans l'accès à l'eau sont les symptomes d'un antagonisme croissant entre le développement économique et les problèmes de société et d'environnement au Brésil. Cet éloignement progressif résulte d'un processus plus ample d'accumulation du capital et de l'insertion subordonnée du Brésil dans le marché mondial. Des réformes institutionelles récentes permettent d'aborder de façon nouvelle le problème des ressources hydriques, par l'utilisation d'instruments simulateurs du marché, comme le paiement de l'eau consommée, qui opérationnalise la gestion de l'environnement. Cependant ce nouveau modèle de gestion ne fait que reproduire la même logique de mercantilisation de la nature, qui a été historiquement responsable d'une situation d'oppression politique et de dégradation du milieu. Des réponses effectives aux problèmes de l'environnement exigeront une modification des rapports de pouvoir, du rôle de l'État et de la division internationale du travail.

Mots-clés: Paiement de l'eau consommée, loi des resssources hydriques, gestion des bassins hydrographiques, justice environnementale, Paraíba du Sud, Brésil.

\section{INTRODUÇÃO}

Esse texto discute problemas subjacentes da gestão de recursos hídricos no Brasil à luz de um enfoque histórico-geográfico. À primeira vista, pode parecer exagerada a afirmação de que um país como o Brasil, com vastos rios e aquíferos, necessite reavaliar as suas práticas de uso e conservação da água. Contudo, as próximas páginas irão demonstrar como factores político-económicos têm contribuído para gerar crescentes níveis de escassez hídrica e desiguais oportunidades de acesso à água. $\mathrm{O}$ controlo dos recursos hídricos foi e continua a ser um dos pilares da agroindústria brasileira na medida em que responde a monumentais procuras por água e energia eléctrica. Sob a liderança de governos autoritários, a manipulação da água foi altamente funcional para a expansão económica e, em última análise, para a acumulação de capital. Mas a apropriação dos recursos hídricos inexoravelmente levou a conflitos entre grupos sociais, ao mesmo tempo que produziu impactos ambientais severos, tais como destruição de habitats, interrupção do fluxo de sedimentos, poluição superficial e subterrânea, modificação do regime sazonal de vazões, etc.

A última década foi cenário de significativa reformulação institucional e modernização dos procedimentos de gestão de recursos hídricos. Enquanto no passado a ênfase recaía sobre a expansão da infra-estrutura estatal, os actuais métodos de gestão exigem a tercearização de serviços públicos, a privatização de empresas governamentais e a adopção de instrumentos económicos de regulação ambiental. Apesar da intensa mobilização, o novo modelo tem produzido respostas incapazes de atender à complexidade socionatural das questões da água em função de uma subordinação explícita a prioridades económicas e a estruturas políticas historicamente estabelecidas. Há, assim, uma velada dissimulação daquilo que é aparentemente novo, mas genuinamente velho na gestão dos recursos hídricos no Brasil. O equívoco fundamental da reforma em curso 
é ignorar que os problemas de uso e conservação da água decorrem de uma condição de capitalismo agroindustrial periférico, submetido a aceleradas taxas de urbanização e responsável por graves injustiças sociais.

\section{BASES TEÓRICAS PARA A ANÁLISE DOS PROBLEMAS SOCIOAMBIENTAIS}

Antes de analisar o caso brasileiro, é importante esclarecer as bases teóricas da abordagem aqui proposta. O ponto de partida é a constatação de que a água é essencial a incontáveis processos naturais e, ao mesmo tempo, é parte integral de muitas relações sociais. Não é possível, portanto, dissociar a circulação das águas da interferência humana, nem ignorar as circunstâncias hidrológicas de comunidades e civilizações. Em razão dessa relação de interdependência entre sociedade e recursos hídricos, o que se denomina de ciclo hidrológico é, na verdade, um ciclo "hidrosocial". Conforme Swyngedouw (2004), natureza e sociedade transformam-se numa nova categoria socionatural que é o resultado de transformações em configurações preexistentes que são em si mesmas naturais e sociais. Desse modo, o mundo descreve um metabolismo perpétuo no qual processos sociais e naturais se combinam na produção de socionatureza, o qual nunca termina, mas é altamente politizado, contestado e contestável. A chamada "gestão dos recursos hídricos" nada mais é do que um processo de intervenção e redireccionamento da dialéctica socionatural, o qual se vale da manipulação do ciclo "hidrosocial" para a satisfação das necessidades humanas.

Problemas advindos da gestão dos recursos hídricos, como poluição e escassez de água, decorrem de um estranhamento entre natureza e sociedade, ou seja, como se a relação socionatural estivesse ocorrendo em dois campos estranhos e separados. No mundo moderno, tais problemas ambientais têm origem na contradição básica entre as relações de produção e as condições estruturais de produção (O'Connor, 1998), ou seja, produz-se para atender as exigências do mercado e acumular capital em benefício próprio, ignorando que isso resulta numa demanda por recursos naturais além dos limites ecologicamente sustentáveis e com consequências negativas permanentes. Assim, com demandas irrefreáveis, a expansão da actividade económica reduz a natureza a mera fornecedora de mercadorias (commodities) e deixa-a sujeita a transacções de mercado. Castree (2003) identifica a comodificação da natureza como decorrência de diversos processos, tais como privatização (controlo privado dos recursos naturais), alienação (separação entre a natureza sendo vendida e os antigos controladores), individualização (separação entre o recurso e o seu contexto), abstracção (homogeneização dos recursos naturais) e valorização (atribuir valor aos recursos naturais). A comodificação da natureza é determinada por circunstâncias locais e não ocorre automaticamente, mas através de lutas políticas e conflitos institucionais em diferentes escalas (Robertson, 2002).

Nas últimas duas décadas, a comodificação da natureza tem se aprofundado em razão da hegemonia dos princípios neoliberais (i.e., neoclássicos) de eficiência de mercado e empreendedorismo. Segundo Bakker (2002), no sector de águas, esse processo teve início não no mercado, mas foi proposto pelo Estado através de mecanismos de "re-regulação", ao invés de "des-regulação", que não modificam as bases históricas de exploração de recursos naturais e exclusão social, mas apenas geram novas oportunidades económicas dissimuladas na premissa de que o mercado é mais eficiente que os 
governos no provimento de serviços relacionados à água. Em oposição a tais transformações, populações tradicionais e grupos de contestação têm denunciado os persistentes e generalizados impactos socioambientais da reforma neoliberal (Johnston, 2003). A oposição às políticas hegemónicas defende que o acesso à água seja equitativo e justo para todos os grupos sociais, bem como garanta uma continuação indefinida dos sistemas socioambientais. A busca de alternativas ao modelo dominante de gestão de águas advoga, assim, uma transformação que é parte de mudanças mais gerais nas relações de poder, no papel do Estado e na divisão internacional do trabalho.

\section{DESENVOLVIMENTO ECONÓMICO E USO DOS RECURSOS HÍDRICOS}

Desde o começo da sua história no século XVI até às primeiras décadas do século passado, a divisão internacional do trabalho atribuiu ao Brasil a função de fornecedor de matérias-primas e, mas tarde, consumidor de mercadorias dos países capitalistas centrais. A exportação de açúcar, ouro e café, entre outros produtos primários, foi responsável por sucessivos ciclos de acumulação seguidos por períodos de estagnação e desorganização social. A base agrícola e extractiva da economia brasileira, implantada ainda durante o domínio português (1500/1822), começou a transformar-se a partir de 1930, por meio de uma industrialização liderada pelo Estado. A liderança governamental serviu para superar a base agrícola anteriormente estabelecida e ceder espaços cada vez mais favoráveis à circulação e acumulação privada de capital. A principal estratégia adoptada foi substituir as importações e fortalecer o mercado interno, de modo que áreas consideradas estratégicas passaram a ser estimuladas e protegidas da competição de produtos importados por meio de barreiras legais e tarifárias. Como observa Faoro (1977), o desenvolvimento económico e o controlo político no Brasil historicamente basearam-se no patrimonialismo, definido por uma ordem burocrática que compreende dimensões públicas e privadas, combinando elementos de paternalismo, repressão, hierarquia e autoritarismo.

Ao longo de sua industrialização, a economia brasileira incorporou gradualmente elementos hidrológicos, o que produziu uma crescente comodificação da água, seja através de capitais investidos em infra-estrutura hídrica, seja por meio da provisão de serviços de água e energia eléctrica às actividades produtivas. Essa transformação da geografia da água para atender aos imperativos do crescimento económico acabou por modificar não somente as características físicas, químicas e biológicas do ambiente aquático, mas produziu uma hierarquia de oportunidades sociais que reflecte a estratificação mais geral da sociedade brasileira. Por outras palavras, os maiores beneficiários da expansão hídrica foram as parcelas mais avantajadas da sociedade, enquanto populações mais pobres, como comunidades expulsas pela construção de novos reservatórios, arcaram com as consequências negativas do desenvolvimento (Acselrad et al., 2004). Isso sugere que os problemas sociais e ambientais da gestão de águas são, na verdade, problemas do próprio modelo brasileiro de desenvolvimento económico. Para se entender as contradições do desenvolvimento hídrico no Brasil, o século XX pode ser esquematicamente descrito em três grandes fases:

1) Pré-industrialização (1900/1930): nas primeiras décadas do século, a economia brasileira contava com uma base fundamentalmente agrícola e dependente do café, borracha e cacau como principais produtos de exportação. Alguns anos 
antes, a abolição da escravatura (1888) e, especialmente, a chegada de imigrantes italianos, japoneses e alemães, entre outros povos, passaram a contribuir para a emergência de um restrito mercado interno e progressiva urbanização. No final dos anos 20, a população chegou a 17,5 milhões de pessoas, $80 \%$ ainda vivendo em zonas rurais. O serviço público de abastecimento de água era circunscrito às áreas mais aquinhoadas dos maiores centros urbanos. Grande parte do abastecimento era controlado por empresas particulares, muitas delas estrangeiras. Em relação às actividades que utilizam água nos processos produtivos, a geração de energia eléctrica restringia-se a algumas poucas empresas de capital britânico e americano (Kelman et al., 1999). A irrigação agrícola destinava-se à produção meridional de arroz, a primeira cultura a ser produzida de forma industrial. Na região semiárida do Nordeste brasileiro, em 1919 é criado o Departamento Nacional de Obras Contra as Secas (DNOCS) com o propósito de minimizar o impacto das estiagens, embora com resultados insatisfatórios.

2) Industrialização (1930/1980): com a revolução populista de 1930, à oligarquia agrária passa a dar lugar uma emergente burguesia comercial e industrial, a qual mantém um estilo de governo autoritário e centralizador (Guimarães, 1991). Entre períodos de democracia nominal e ditadura formal (civil e militar), houve um processo de rápida industrialização, responsável por uma taxa de crescimento da economia de 7\% ao ano entre 1945/1980 (OECD, 2001). Parte integrante desse processo, a expansão da infra-estrutura hídrica incluiu pesados investimentos e uma reconfiguração da estrutura administrativa. A expansão da hidroeletricidade foi fundamental para a industrialização e urbanização no Brasil, uma vez que esta tecnologia é responsável por grande parte da matriz energética nacional (quadro I). A geração de energia eléctrica foi quase toda nacionalizada na década de 50 e, a partir de então, o sector expandiu-se de modo expressivo. Como pode ser visto no quadro I, a potência hidroeléctrica aumentou de 615MW (megawatts) em 1930 para 44 900MW em 1990.

Ao longo do século XX, mais de 570 grandes unidades geradoras de energia hidroeléctrica foram instaladas no país. Em 1984, a ditadura militar inaugurou Itaipu, instalação com uma capacidade geradora de 12 600MW. Itaipu é ainda hoje a maior hidroeléctrica do mundo, mas cabe ressaltar que a sua construção desalojou 42444 moradores e destruiu $1350 \mathrm{~km} 2$ de ecossistemas locais. Apesar da expansão da infra-estrutura hidráulica, existe uma desigualdade social semelhante àquela do sector de abastecimento de água, em razão da oferta de energia per capita ser ainda limitada (200kwh/ano, apenas a $80 .^{\text {a }}$ taxa no mundo) e $12 \%$ da população continuar sem abastecimento (Bello, 2005).

As áreas de irrigação cresceram a uma taxa de 30\% por década, desde 1950, e expandiram-se do Sul para outras regiões do país, especialmente para o Sudeste e Nordeste, conforme pode ser visto na figura 1. A irrigação foi um dos pilares da Revolução Verde, que fez do Brasil um dos principais exportadores do agronegócio mundial, ainda que tenha sido responsável por impactos ambientais e crescentes conflitos pelo uso de água. No semiárido, apesar de diversos projectos de irrigação e da criação da Companhia de Desenvolvimento dos Vales do São Francisco (CODEVASF) em 1948 e da Superintendência do Desenvolvimento do Nordeste (SUDENE) em 1959, a escassez de água continuou a afectar largas parcelas da população regional. Segundo Hall (1978), o problema da seca relacionava-se com a estrutura agrária nordestina, onde 
a terra historicamente se concentrava nas mãos de líderes políticos, deixando a maioria da população vulnerável mesmo às menores vicissitudes climáticas. Esse quadro de desigualdade hídrica continua até hoje, uma vez que os reservatórios de água ainda se concentram em terras de grandes proprietários, deixando cerca de 92\% das famílias de agricultores sem acesso à irrigação (IBGE, 1996, citado em Lemos e Oliveira, 2005). As acções emergentes continuam a ser controladas pela mesma oligarquia agrária, a qual sistematicamente manipula os programas governamentais para benefício próprio e não permite que a ajuda chegue às populações mais afectadas pela seca (Ioris, 2001).

Quadro I - Evolução da geração de hidroeletricidade no Brasil (Fonte: Santos e Freitas, 2000)

Table I - Evolution of hydropower generation in Brazil (Source: Santos e Freitas, 2000)

\begin{tabular}{cccc}
\hline Ano & $\begin{array}{c}\text { Potência } \\
\text { Instalada (MW) }\end{array}$ & $\begin{array}{c}\text { Taxa Anual de } \\
\text { Crescimento (\%) }\end{array}$ & $\begin{array}{c}\text { Hidroeletricidade como } \\
\text { percentagem do total } \\
\text { de energia (\%) }\end{array}$ \\
\hline 1920 & 370,1 & $\ldots$ & 77,8 \\
1930 & 615,2 & 5,21 & 80,8 \\
1940 & 1009,4 & 5,08 & 81,1 \\
1950 & 1535,7 & 4,29 & 81,6 \\
1960 & 3642,0 & 9,02 & 75,9 \\
1970 & 9088,0 & 9,58 & 79,3 \\
1980 & 25584,0 & 10,90 & 81,6 \\
1990 & 44900,0 & 3,93 & 91,6 \\
{$[1999]$} & 59548,0 & 6,24 & 89,4 \\
\hline
\end{tabular}

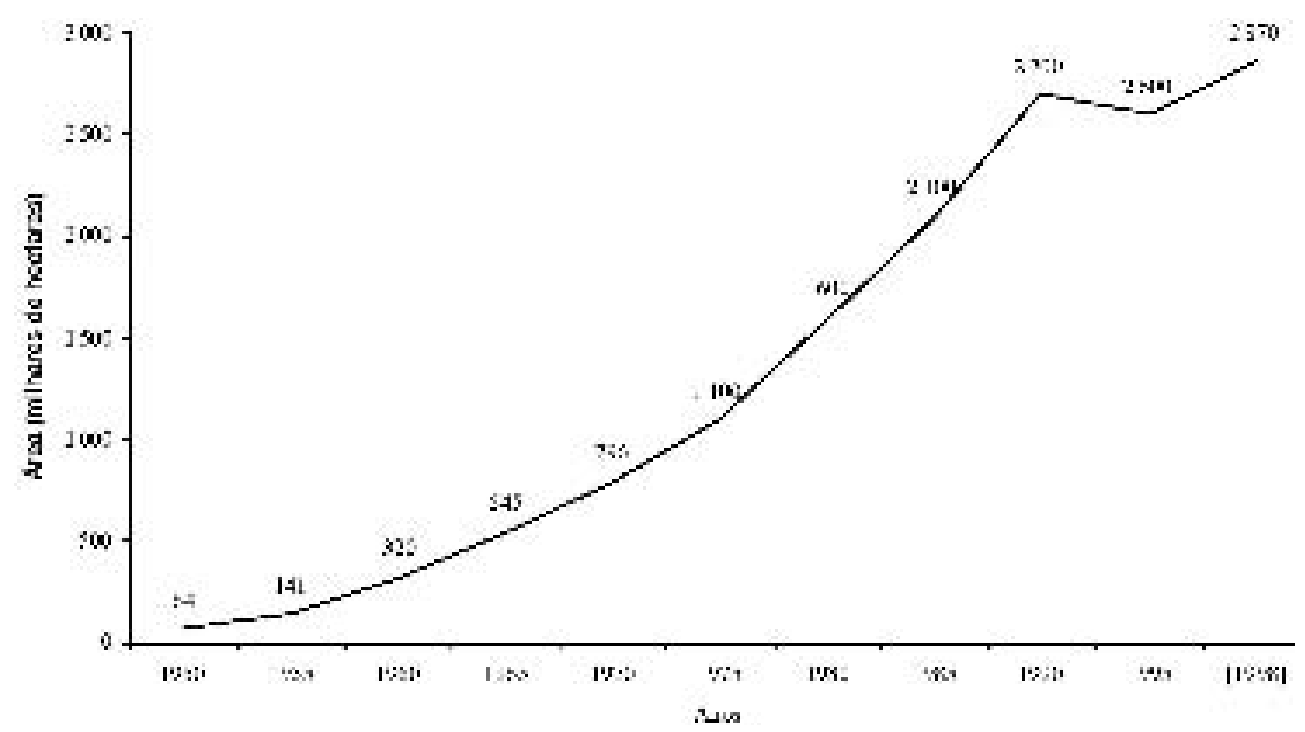

Fig. 1 - Expansão da área de irrigação no Brasil (Fonte: Lima et al., 1999).

Fig. 1 - Expansion of the area of irrigation in Brazil (Source: Lima et al., 1999). 
No sector de abastecimento de água, em 1934, é introduzido um sistema mais centralizado de planeamento e é criado o Departamento Nacional de Obras Sanitárias (DNOS) com o objectivo de subvencionar as companhias municipais. O passo mais importante foi o lançamento em 1971 do Plano Nacional de Saneamento (PLANASA), o que permitiu a expansão do sector através do fortalecimento das companhias estaduais de abastecimento. Contudo, seguindo o modelo injusto do desenvolvimento brasileiro, a expansão dos serviços de água e esgotos vieram a atender de modo diferenciado as populações com menor ou maior renda familiar. Os grupos com maior renda passaram a ser mais bem servidos, em especial em termos de recolha e tratamento de efluentes. Em 1989, apenas 24,2\% das famílias que recebiam até dois salários mínimos contavam com serviço público de recolha de esgotos, contra 47,8\% das famílias que recebiam mais de cinco salários mínimos (ver mais detalhes no quadro II).

\section{Quadro II - Provisão de Serviços Públicos de Água e Esgotos no Brasil (Fonte: Serôa da Motta $e$ Rezende, 1999) \\ Table II - Provision of Public Water Services in Brazil (Source: Serôa da Motta and Rezende, 1999)}

\begin{tabular}{lcccccc}
\hline \multirow{2}{*}{$\begin{array}{l}\text { Domicílios por } \\
\text { renda familiar }\end{array}$} & \multicolumn{2}{c}{$\begin{array}{c}\text { Abastecimento } \\
\text { de Água }\end{array}$} & \multicolumn{2}{c}{$\begin{array}{c}\text { Rede } \\
\text { de Esgotos }\end{array}$} & \multicolumn{2}{c}{$\begin{array}{c}\text { Tratamento } \\
\text { de Esgoto }\end{array}$} \\
\cline { 2 - 7 } & $\mathbf{1 9 8 1}$ & $\mathbf{1 9 8 9}$ & $\mathbf{1 9 8 1}$ & $\mathbf{1 9 8 9}$ & $\mathbf{1 9 8 1}$ & $\mathbf{1 9 8 9}$ \\
\hline & 59,3 & 76,0 & 15,0 & 24,2 & 0,6 & 4,7 \\
0-2 SM & 76,3 & 87,8 & 29,7 & 39,7 & 1,3 & 8,2 \\
2-5 SM & 90,7 & 95,2 & 54,8 & 61,2 & 2,5 & 13,1 \\
> 5 SM & 78,4 & 89,4 & 36,7 & 478 & 1,6 & 10,1 \\
\hline Todos os grupos & &
\end{tabular}

$\mathrm{SM}=$ Salário Mínimo Oficial (aproximadamente $€ 90$ por mês)

3) Flexibilização económica (a partir de 1990): em consequência de uma crescente desorganização da produção causada pela perda de hegemonia política na década de 1980, o governo brasileiro passou a adoptar medidas económicas ortodoxas para fortalecer a moeda e controlar a pressão inflacionária. Fazendo eco a exigências de organismos internacionais, criaram-se condições mais favoráveis para atrair investidores estrangeiros, em particular para a privatização de empresas públicas. No sector hidroeléctrico, são adoptadas diferentes estratégias de privatização, como a venda de parcela minoritária de acções, venda de parcela maioritária de acções e transferência do controlo das empresas, ou divisão em empresas menores e venda a investidores privados. A privatização do sector hidroeléctrico foi responsável por negócios de 23,5 mil milhões de dólares (i.e., $10^{9}$ dólares), o que representou um terço do programa federal de desestatização (valores de 1999), ainda que, para favorecer os investidores, o governo passou a oferecer empréstimos de bancos oficiais (15 mil milhões de dólares entre 1995 e 2001). Como benefício adicional, o governo passou a aceitar cláusulas contratuais que protegem as empresas privatizadas contra oscilações de câmbio, além de permitir o reajuste de tarifas acima da inflação e tolerar a eliminação de subsídio a famílias de baixíssima renda (Anuatti-Neto et al., 2003). Até ao momento, a privatização não contri- 
buiu para aumentar a oferta de energia, mas, pelo contrário, aumentou as tarifas e criou incertezas quanto ao futuro do sector e à segurança do abastecimento (Bello, 2005).

Os serviços de água e esgotos constituem dos sectores públicos com maior procura por investimentos no Brasil, uma vez que, segundo o Ministério das Cidades, quase a metade da população não é ainda atendida por sistemas de esgotos e um quarto ainda carece de serviços de distribuição de água potável; nas áreas rurais, mais de $80 \%$ das moradias não são servidas por redes gerais de abastecimento de água e quase $60 \%$ dos esgotos de todo o país são lançados, sem tratamento, directamente nos cursos de água. Para reverter este quadro, resultante de anos de negligência e má administração, estimase que seriam necessários investimentos de $0,45 \%$ do PIB (R $\$ 6$ mil milhões ou $€ 2,250$ mil milhões por ano) por duas décadas (IPEA, 2004). Com tais valores envolvidos, há um declarado interesse de investidores privados em participar da reestruturação do sector (algumas das principais multinacionais europeias já se instalaram no país, como a Águas de Portugal, a Lyonnaise des Eaux, a Générale des Eaux e a Thames Water). Existem 318 empresas estaduais e municipais de abastecimento e saneamento, mas apenas 3\% foram privatizadas até ao momento (Serôa da Motta, 2004). A reformulação do saneamento básico é objecto de um exaltado debate político no Congresso Nacional, com idas e vindas de diversos projectos de lei, mas ainda sem suficiente acordo político que permita a aprovação de um novo marco legal. Uma das questões mais controversas a respeito da privatização do saneamento é o risco de se manter e aprofundar a estratificação social na prestação de serviços (Vargas, 2005). A menos que se criem rigorosos mecanismos sociais compensatórios, é de se esperar que a expansão da privatização do sector de abastecimento de água e saneamento agrave ainda mais as desigualdades sociais, uma vez que os investidores naturalmente preferem adquirir empresas que servem às populações de maior renda, por duas razões básicas: esses grupos têm uma maior procura por serviços e, mais importante, são as zonas onde no passado a maioria dos investimentos em infra-estruturas foram feitos.

\section{O PAPEL DO “NOVO MODELO” DE GESTÃO AMBIENTAL}

Conforme descrito, o controlo e a manipulação dos recursos hídricos foram elementos fundamentais para a industrialização e urbanização do Brasil. Um esforço nacional, sob o comando do Estado, foi responsável pela construção de grandes barragens, regularização de rios e controlo do regime hidrológico. Gradualmente, porém, com o agravamento da degradação ambiental em todas as regiões brasileiras, os custos de armazenagem, captação e distribuição de água passam a crescer proporcionalmente. Ou seja, as contradições do desenvolvimento transformaram uma situação de relativa abundância em relativa escassez (tanto hídrica quanto financeira). Em consequência, a ênfase da gestão de recursos hídricos começou a distanciar-se da simples expansão da oferta para estratégias baseadas na redução da procura de água e na recuperação do passivo ambiental. Isso coincidiu com o enfraquecimento do Estado frente às pressões neoliberais por soluções baseadas em regras de mercado.

Uma nova estrutura institucional foi introduzida na década de 1990 para dar resposta aos problemas socioambientais do passado, tendo como ponto culminante a aprovação da Política Nacional de Recursos Hídricos contida na Lei 9433 de Janeiro de 
1997. O novo marco regulatório é baseado em instrumentos de comando e controlo (i.e., planos de bacia, autorização para captação e uso da água, classificação dos cursos de água e sistemas de informação) e em incentivos económicos para o uso "racional" dos recursos hídricos (i.e. cobrança pelo uso da água e compensações financeiras $)^{2}$. Para implementar a nova legislação, foi criado o Sistema Nacional de Gerenciamento de Recursos Hídricos (SINGREH), que inclui o Conselho Nacional de Recursos Hídricos, o Ministério do Meio Ambiente, o Instituto Brasileiro do Meio Ambiente e dos Recursos Naturais Renováveis (IBAMA) e, desde 2001, a Agência Nacional de Águas (ANA). Há uma estrutura equivalente para regular a gestão de rios sob domínio estadual.

Apesar da introdução de uma complexa e onerosa estrutura institucional, na prática têm se verificado apenas mudanças superficiais no tratamento dos recursos hídricos. A gestão continua a concentrar-se nos aspectos técnico-económicos do uso da água, deixando de oferecer respostas aos problemas sociais e ambientais criados pelo próprio desenvolvimento. Em que, pese a incorporação do discurso de sustentabilidade, as relações subjacentes de poder e os mecanismos de acumulação não foram afectados pelos novos procedimentos de gestão ambiental. Apesar de canais aparentemente democráticos, como os comités de bacia hidrográfica, a estrutura de gestão segue dominada pelos mesmos sectores económicos e políticos que no passado sempre exerceram hegemonia (Valencio e Martins, 2005). Tais sectores têm conseguido preservar e até mesmo ampliar os privilégios historicamente estabelecidos, o que demonstra que o antigo paradigma de desenvolvimento hídrico foi transferido para o presente e continua a dominar as relações entre sociedade e ambiente.

O exemplo mais nítido da perpetuação das distorções do passado nas novas práticas de gestão é dado pela adopção de instrumentos de mercado (ou simuladores de mercado), em especial a cobrança pelo uso da água. Segundo a actual legislação (Lei 9433 de 1997), a captação de água e o lançamento de efluentes estão sujeitos à outorga prévia junto ao órgão regulador (federal ou estadual) e devem pagar uma taxa anual proporcional aos custos sociais criados pelas externalidades económicas. Formalmente, a cobrança tenta remover as ineficiências relacionadas com o "antigo paradigma de gestão", o qual conduzia ao desperdício, uma vez que a água estava disponível gratuitamente (Kelman, 2000). Tal justificativa baseia-se no princípio neoclássico de que incentivos de mercado promovem uma eficiente alocação e uso de recursos (Winpenny, 1994), de modo que, dependendo do preço pago pelos utilizadores, se estabelece um nível racional e sustentável de utilização (Garrido, 2005). Ao mesmo tempo, a cobrança é defendida como alternativa mais eficiente do que a arrecadação de impostos para financiar acções de regulação e recuperação ambiental (Campos e Studart, 2000).

Apesar de contar com uma sólida fundamentação teórica, a implementação da cobrança foi inicialmente lenta no Brasil, principalmente em razão de complexas disputas

2 Os instrumentos de gestão ambiental adoptados no Brasil são todos inspirados em procedimentos oriundos dos países capitalistas centrais (países da Europa, Austrália e Estados Unidos). Através de pressões das agências internacionais, países como o Brasil têm sido forçados a incorporar práticas alienígenas de gestão ambiental que ignoram especificidades hidrológicas, legislativas e culturais. Desse modo, há uma grande coincidência entre os fundamentos da nova regulação dos recursos hídricos no Brasil, por exemplo ao nível dos objectivos, e a Directiva Quadro de Águas na Europa (Ioris, 2004). Tal como no Brasil, a nova legislação europeia evidencia a dificuldade de se conciliarem interesses de mercado, disputas políticas e socioambientais (Kaika, 2004). 
técnicas e políticas dentro e fora do Governo. A controvérsia começou em 2000, quando a mesma lei que criou a Agência Nacional de Águas estabeleceu que a geração hidroeléctrica seria o primeiro sector sujeito à cobrança pelo uso da água. Entretanto, para surpresa do Sistema Nacional de Gerenciamento de Recursos Hídricos, o Ministério da Fazenda classificou inesperadamente a cobrança como imposto ordinário, o que a deixou sujeita a decretos de contingência do orçamento público (que vêm sendo sistematicamente adoptados nos últimos anos por influência do Fundo Monetário Internacional para manter o superavit primário das contas governamentais). Devido a esse contexto desfavorável, nos primeiros anos o instrumento da cobrança encontrava-se numa situação de impasse, o que colocava em risco a credibilidade de toda a nova estrutura de gestão de águas ${ }^{3}$.

Depois de um longo processo de avanços e recuos, um novo patamar de consenso político permitiu que, em Março de 2005, o Conselho Nacional de Recursos Hídricos aprovasse os critérios operacionais e as prioridades para aplicação dos recursos provenientes da cobrança pelo uso da água (ainda que sem uma solução definitiva para a classificação tributária da cobrança pelo Ministério da Fazenda). A decisão do Conselho tornou possível expandir a cobrança a todos os responsáveis por captação da água e descarga de efluentes em rios sob responsabilidade do governo federal. A primeira unidade a adoptar as novas determinações foi a bacia hidrográfica do Paraíba do Sul (na região Sudeste), onde a metodologia de cálculo inclui três variáveis: volume captado, percentagem efectivamente consumida e volume requerido para diluição de efluentes. Isto resulta em valores médios de $\mathrm{R} \$ 0,08 / \mathrm{m}^{3}\left(€ 0,03 / \mathrm{m}^{3}\right)$ para captação e mais $\mathrm{R} \$ 0,02 / \mathrm{m}^{3}$ $\left(€ 0,007 / \mathrm{m}^{3}\right)$ consumido (Braga et al., 2005).

A histórica decisão do Conselho Nacional de Recursos Hídricos foi baseada num acordo político entre grupos económicos que perceberam que, além de não ameaçar os seus interesses, a cobrança lhes pode ser altamente instrumental. Da forma como foi adoptada, a cobrança permite a recuperação do passivo ambiental, mas divide a conta da recuperação com toda a população, uma vez que os clientes dos serviços de abastecimento de água e esgotos arcam com a maior parcela a ser arrecadada (em Paraíba do Sul, os serviços de água e esgotos contribuíram com 4,1 milhões de reais em 2004, contra 2,2 pagos pelas indústrias; esses valores equivalem a 1,5 e 0,8 milhão de euros respectivamente). Desse modo, ao invés de cobrar daqueles directamente responsáveis pela degradação do ambiente aquático (indústria e agricultura, em particular), o ónus é distribuído com toda a sociedade, mesmo com quem no passado nunca teve acesso a serviços públicos de água e esgotos.

Os defensores da nova estrutura de gestão ambiental negam essas consequências injustas e insistem que a cobrança é um instrumento vantajoso para toda sociedade (como pode ser visto nos jornais após a aprovação das resoluções do Conselho em Março de 2005). Para convencer a população, organizou-se uma sofisticada "política de mistificação" que promove a ideia que todos são igualmente responsáveis pela degradação do ambiente, encobrindo o facto de que os benefícios do desenvolvimento hídrico foram historicamente apropriados de maneira desigual pelo diferentes grupos sociais. Trata-se de uma defesa ideológica e demagógica, uma vez que esconde que os novos instrumentos de regulação ambiental, além de não reverterem as distorções do modelo de desenvolvimento hídrico, aprofundam as contradições da acumulação económica

3 Entrevista do autor com superintendentes da Agência Nacional de Águas em 2002. 
capitalista. A política de mistificação impede qualquer questionamento sobre as causas das desigualdades sociais do passado, bem como sobre a manutenção de tais injustiças no presente.

Reflectindo sobre a experiência recente, fica claro que a cobrança pelo uso da água é um instrumento de gestão ambiental trazido ao Brasil de forma mecânica, sob pressão de organismos internacionais e com o propósito de abrir novos canais de comodificação da natureza e acumulação de capital. Os novos instrumentos de gestão ambiental, como a cobrança, terminam reforçando a comodificação da água e aprofundam a inserção do ambiente aquático na circulação de capital. A cobrança é uma solução mistificadora que responde a um falso problema, ou seja, a geração de recursos financeiros para manter um padrão descriminador de desenvolvimento hídrico. Isso faz com que a questão crucial permaneça sem resposta: nem o novo modelo de gestão nem as iniciativas do passado atendem à maioria da população, mas servem para manter a mesma lógica de exclusão social e exploração dos recursos naturais que sempre caracterizou o desenvolvimento económico brasileiro.

\section{CONCLUSÃO}

A incorporação da geografia da água ao processo de produção capitalista, largamente fomentada por organismos internacionais, foi responsável por uma progressiva comodificação do ambiente aquático. O processo resultou em complexas contradições sociais e ambientais, particularmente numa crescente assimetria entre benefícios económicos e impactos sociais decorrentes da degradação do ambiente. Com a desmedida expansão urbano-industrial, os níveis de degradação ambiental passaram a restringir a própria expansão económica e forçaram respostas institucionais diversas, culminando com a promulgação da nova legislação de águas e a institucionalização de um sistema nacional de gestão. Apesar do novo discurso oficial de sustentabilidade ambiental, instrumentos de gestão como a cobrança pelo uso da água têm reproduzido as mesmas contradições do período anterior. A implementação do novo modelo de gestão é baseada numa sofisticada mistificação que encobre o facto de que a conta da recuperação ambiental vem sendo dividida com toda a sociedade, ao invés de responsabilizar directamente os causadores da degradação.

Os problemas relacionados ao uso e conservação da água no Brasil são consequência directa de um modelo económico perverso e implantado por um Estado autoritário. Injustiça ambiental e práticas autoritárias de gestão continuam a ser a característica marcante da acção do poder público e dos principais agentes económicos. As distorções da gestão dos recursos hídricos são resultado de processos descriminatórios na relação entre sociedade e natureza que decorrem da contradição básica entre relações e condições de produção. Respostas efectivas aos problemas da água dependem do reconhecimento das responsabilidades políticas pelos impactos socionaturais que se projectaram do passado para o presente. As questões da água configuram-se, assim, como elementos importantes da democratização do Estado e da revisão de padrões de produção e consumo. Somente com uma gestão ambiental independente das forças de mercado será possível começar a estabelecer novas bases para a construção de uma relação mais justa e menos contraditória entre a sociedade e o resto da natureza. 


\section{BIBLIOGRAFIA}

Acselrad H, Herculano S, Pádua J A (eds) (2004) Justiça ambiental e cidadania. Relume Dumará, Rio de Janeiro.

Anuatti-Neto F, Barossi-Filho M, Carvalho A, Macedo R (2003) Costs and benefits of privatization: evidence from Brazil. Inter-American Development Bank, Washington, DC.

Bakker K (2002) From state to market? Water mercantilización in Spain. Environment and Planning A, 34: 767-790.

Bello C A (2005) O racionamento de energia e o apagão da cidadania: expressões de um novo neopatrimonialismo estatal. UNESCO [Acedido em 02 de Agosto de 2005]. http://www.unesco.org/most/globalisation/rapfinal-nedic.htm

Braga B P F, Strauss C, Paiva F (2005) Water charges: paying for the commons in Brazil. Water Resources Development, 21(1): 119-132.

Campos J N B, Studart T M C (2000) An historical perspective on the administration of water in Brazil. Water International, 25(1): 148-156.

Castree N (2003) Commodifying what nature? Progress in Human Geography, 27(3): 273-297.

Faoro R (1977) Os donos do poder: formação do patronato político brasileiro. Editora Globo, Porto Alegre.

Garrido R (2005) Price setting for water use charges in Brazil. Water Resources Development, 21(1): 99-117.

Guimarães R (1991) The ecopolitics of development in the third world: politics and environment in Brazil. Lynne Rienner Publishers, Boulder and London.

Hall A (1978) Drought and irrigation in north-east Brazil. University Press, Cambridge.

Ioris A A R (2004) Desafios institucionais para a implementação da directiva quadro de águas na Escócia. IV Congresso Ibérico sobre Gestão e Planificação da Água, Tortosa, 08-12 Dez. 2004.

Ioris A A R (2001) Water resources development in the São Francisco river basin (Brazil): conflicts and management perspectives. Water International, 26(1): 24-39.

IPEA (Instituto de Pesquisa Econômica Aplicada) (2004) Sistema Nacional de Informações sobre Saneamento: visão geral da prestação dos serviços de água e esgotos - 2003. Ministério das Cidades, Brasília.

Johnston B (2003) The political ecology of water: an introduction. Capitalism Nature Socialism, 14(3): 73-90.

Kaika M (2004) Water for Europe: the creation of the European water framework directive. In Trottier J, Slack P (eds) Managing water resources: past and present. University Press, Oxford: 89-116.

Kelman J (2000) Evolution of Brazil's water resources management system. In Canali G V, Correia F N, Lobato F, Machado E S (eds) Water resources management: Brazilian and European Trends and Approaches. ABRH, Porto Alegre: 19-36.

Kelman J, Pereira M, Neto T, Sales P (1999) Hidreletricidade. In Rebouças A, Braga B P F, Tundisi J (eds) Águas doces do Brasil: capital ecológico, uso e conservação. Escrituras Editora, São Paulo: 371-418.

Lemos M C, Oliveira J L F (2005) Water reform across the state/society divide: the case of Ceará, Brazil. Water Resources Development, 21(1): 133-147.

Lima J, Ferreira R, Christofidis D (1999) O uso da irrigação no Brasil. O estado das águas no Brasil: perspectivas de gestão e informação de recursos hídricos. ANEEL, SRH/MMA e MME, Brasília: 73-82. 
Robertson M (2002) No net loss: wetland restoration and the incomplete capitalization of nature. Antipode, 32(4): 463-493.

O'Connor J (1998) Natural causes: essays in ecological marxism. Guilford, New York and London.

OECD (Organisation for Economic Cooperation and Development) (2001) Economic surveys 20002001: Brazil. Paris.

Santos A H M, Freitas M A V (2000) Hydropower and development in Brazil. Seminar Dams, Development and Environment, São Paulo, 14-16 Fev. 2000. Inter-American Development Bank, Washington DC: 59-72.

Serôa da Motta R (2004) Questões regulatórias do setor de saneamento no Brasil, Notas Técnicas N. ${ }^{\circ}$ 5. Instituto de Pesquisa Econômica Aplicada, Rio de Janeiro.

Serôa da Motta R, Rezende L (1999) The impact of sanitation on waterborne disease in Brazil. In May P H (ed.) Natural resource valuation and policy in Brazil: methods and cases. Columbia University Press, New York: 174-187.

Swyngedouw E (2004) Social power and the urbanization of water: flows of power. University Press, Oxford.

Valencio N F L S, Martins R C (2004) Novas institucionalidades na gestão de águas e poder local: os limites territoriais da democracia decisória. Revista Internacional de Desenvolvimento Local, 5(8): 55-70.

Vargas M (2005) O negócio da água - riscos e oportunidades das concessões de saneamento à iniciativa privada: estudos de caso no sudeste brasileiro. Annablume, São Paulo.

Winpenny J (1994) Managing water as an economic resource. Routledge, London. 



\section{RECENSÕES}

\section{SÍNTESES BIBLIOGRÁFICAS}





\title{
SEGUNDA NOTÍCIA SOBRE UMA GEOGRAFIA DE PORTUGAL NOVA E MONUMENTAL
}

\author{
ILÍDIO DO AMARAL ${ }^{1}$
}

Em Finisterra - Revista Portuguesa de Geografia, 2006, XLI(81): 233-242, foi incluída a "Primeira Notícia", dedicada à parte de Geografia Urbana do segundo volume da Geografia de Portugal, obra sob a direcção geral de Carlos Alberto Medeiros e editada pelo Círculo de Leitores. Na Notícia que ora se publica as informações dizem respeito ao primeiro volume, $O$ Ambiente Físico, Julho/Agosto de 2005, e à parte inicial do segundo, Sociedade, Paisagens e Cidades, Dezembro do mesmo ano. O quadro I dá o encadeamento das matérias tratadas e os seus autores.

Quadro I - Resumos dos índices gerais dos volumes I e II (este sem a parte sobre Cidades) Table I - Summaries of the general indices of volumes I and II (this without the part on Cities)

Volume I - O Ambiente Físico (496 páginas, um pouco mais de duas centenas de figuras e número semelhante de fotos*, 21 quadros, bibliografias extensas**)

Apresentação e Um Preâmbulo Geral. Palavras Prévias (Carlos Alberto Medeiros), pp. 10-47.

O Ambiente Físico. Palavras Prévias (António de Brum Ferreira), pp. 50-51.

Parte I - Formas do relevo e dinâmica geomorfológica (António de Brum Ferreira), pp. 53-255. Introdução. Estruturação geológica do terreno. Geomorfologia do Maciço Antigo. Geomorfologia das Bacias Sedimentares. Geomorfologia vulcânica das ilhas. Formas de relevo e dinâmica quaternária: Dinâmica recente e actual (com duas contribuições, uma de Catarina Ramos, "A Dinâmica Fluvial", e outra de Maria Eugénia Moreira, "A Dinâmica dos Sistemas Litorais").

Parte II - O espaço Atlântico Oriental (Denise de Brum Ferreira), pp. 257-303. Introdução. A dinâmica do Oceano. Hidrologia e dinâmica do mar português. Ambiente oceânico e recursos biológicos.

Parte III - O ambiente climático (Denise de Brum Ferreira), pp. 305-385. Introdução. As condições genéticas do clima. As características do clima de Portugal. O clima de Portugal estará a mudar?

1 Geógrafo. Professor Catedrático Jubilado da Universidade de Lisboa. Colaborador do Centro de Estudos Geográficos de Lisboa. Membro da Academia das Ciências de Lisboa e da Academia Portuguesa da História. E-mail: idoamaral@hotmail.com 
Parte IV - Os recursos hídricos (Catarina Ramos), pp. 387-415.

Introdução. Enquadramento de Portugal no contexto euro-mediterrâneo.

Os recursos hídricos superficiais. Recursos hídricos subterrâneos. Recursos hídricos das Regiões autónomas.

Parte $V$ - A vegetação (Maria Eugénia Moreira e Carlos da Silva Neto), pp. 417-482

Introdução sobre a fitogeografia de Portugal. A vegetação natural.

A vegetação introduzida.

Coordenação do volume: António de Brum Ferreira.

Volume II - Sociedade, Paisagens e Cidades (419 páginas, 163 figuras, 247 fotos, 78 quadros, bibliografias extensas)

Introdução (Teresa Barata Salgueiro e João Ferrão), pp. 12-15.

Parte I - Evolução histórica e ocupação do território (Carlos Alberto Medeiros), pp. 17-47. Primórdios da evolução do País; a expansão marítima e os seus reflexos. Os novos desafios do século XIX; evolução demográfica até ao primeiro censo (1864).

Parte II - População e território (João Ferrão, Isabel Margarida André, Jorge Macaísta Malheiros, João Ferrão e Teresa Sá Marques, Teresa Pinto/Correia), pp. 49-173.

Dinâmicas demográficas: uma visão panorâmica. Família e género. Migrações. População, qualificações e capital cultural. Desenvolvimento humano e coesão social. Paisagem e identidade: da memória à pós-modernidade.

Coordenação do volume: Teresa Barata Salgueiro e João Ferrão.

* Em números aproximados porque algumas imagens têm numeração desdobrada com letras - A, B, ...

** As informações bibliográficas estão em letra menor que a dos textos; estes estão em duas colunas por página, aquelas em três colunas.

\section{O AMBIENTE FÍSICO OU NATURAL}

No início de "O Ambiente Físico", temática fundamental do Primeiro volume, o seu coordenador, António de Brum Ferreira, começou por recordar a distinção feita por Orlando Ribeiro, e tornada clássica, entre um Portugal mediterrânico e um Portugal atlântico (Portugal, o Mediterrâneo e o Atlântico, 1945, e várias reedições), e sublinhou quanto há de variedade e complexidade na área continental e nas ilhas, não só por virtude das diferenças climáticas mas também pela presença de outros factores igualmente importantes e variados, como os materiais rochosos e as suas estruturas, fundações básicas de qualquer território. Os efeitos do clima, porém, incluídas as suas variações temporais e espaciais, têm uma presença constante e visível sobre as paisagens naturais, os processos e evolução das formas de relevo, as condições hidrológicas, as coberturas pedológica e vegetal, e, enfim, a presença efectiva do homem (e todo o resto zoogeográfico) e as suas actividades.

Desde logo os leitores menos informados são avisados do "desigual desenvolvimento de cada uma das partes" do volume, o "que traduz, de certo modo, a evolução díspar da geografia física no nosso país", mais acentuada e ampla em domínios como da geomorfologia e da climatologia, menos os da hidrologia e da fitogeografia, aliás como sucede em muitos outros países. Acrescento eu que nada há de extraordinário no "desigual desenvolvimento", tendo em conta que se trata de uma obra de vários autores, cada um deles com a sua personalidade e os seus interesses em domínios tratados, e os progressos desiguais dos conhecimentos no quadro das especializações de disciplinas afins da Geografia 
no decorrer do século passado. Mas isso não os impediu de verem o global (que a especialização fragmenta em parcelas), bem como o essencial (que ela dissolve). Os problemas essenciais não são jamais parcelares, e os globais são cada vez mais essenciais. Nisto está a virtude desta Geografia de Portugal, da coordenação das várias partes dos seus volumes - repito que, por agora, apenas li atentamente os dois primeiros; o terceiro e o quarto percorri-os por alto - no sentido da garantia de uma harmonia geral.

Em boa hora o Atlântico próximo recebeu a devida atenção, pois desde há muito o oceano deixou "de ser uma mancha azul nos mapas, para se transformar cada vez mais num espaço geográfico, objecto de estudos fundamentais para a compreensão do funcionamento do planeta e, mesmo, para a sobrevivência da humanidade". A propósito disto ocorre recordar a cerimónia oficial que teve lugar em Lisboa, com representações de chefes de Estado e de Governo de vários países, e de muitas outras personalidades importantes, nacionais e estrangeiras, para a apresentação do livro Para uma governação do Oceano no século XXI: Democracia, equidade e paz no Oceano. Declaração de Lisboa, 1998, da Comissão Mundial Independente sobre os Oceanos. Assinalo apenas algumas das ideias fundamentais aí contidas. "A nova perspectiva sobre o Oceano, que inspira esta Declaração, combina cinco elementos": unidade (necessidade de abandonar a imagem tradicional do Oceano como dividido em vários oceanos separados e distintos); urgência (lembrando a gravidade dos desafios manifestados em resultado da utilização actual do Oceano); potencialidade (referida ao extraordinário tesouro que, se bem cuidado e utilizado de forma criativa, o Oceano representa para os povos do mundo); oportunidade (possibilidades que oferecem uma nova ordem mundial e a crescente consciencialização da importância do Oceano para a sobrevivência da humanidade); e tutela (empenhamento activo dos cidadãos e da sociedade em geral no "estado de saúde" do Oceano).

O título da primeira parte do volume, "Formas do relevo e dinâmica geomorfológica", de que o coordenador é autor, marca as tonalidades dominantes de todas as contribuições: o forte dinamismo dos fenómenos geográficos; nada é fixo e imutável na superfície terrestre; pelo contrário, esta deve ser tomada como equiparável a um "corpo vivo" em evolução que varia no tempo e no espaço. Sirva de exemplo o que se passa com o substrato geológico. Se, à escala humana, o Maciço Antigo e as suas Orlas Sedimentares (só na parte continental) podem ser tidos como relativamente invariantes, apenas perturbados, de quando em quando, por uma ou outra falha activa, já os maciços vulcânicos e os sismos (predominantes nas ilhas açorianas) traduzem, de forma clara, a instabilidade da crosta, os movimentos migratórios das suas placas. E de modo idêntico se pode dizer de outras alterações bem visíveis, como as do clima, da hidrologia, da vegetação, para as quais muito contribuem as intromissões humanas, sobretudo as que perturbam o equilíbrio sensível entre a sua presença e a natureza.

"Falar de geografia é falar do território, e o território é, antes de mais, a terra que a gente pisa", são palavras na abertura da "Introdução", a que se seguem os capítulos dedicados à "Estruturação geológica do território", à "Geomorfologia do Maciço Antigo", à "Geomorfologia das Bacias Sedimentares", à "Geomorfologia vulcânica das ilhas", às "Formas de relevo e dinâmica quaternária", e à "Dinâmica recente e actual". Tomando em conta elementos meramente estatísticos, logo se vê que, do total de cerca de 180 páginas, os dois últimos capítulos detêm um pouco mais da metade, o que de certo modo se compreende, tendo em conta os progressos recentes dos estudos sobre os processos e as formas do Quaternário ao Actual, as preocupações de determinação, previsão e monitorização de riscos de origens natural e antrópica, com implicações importantes nos modelos de ordenamento do território. 
O autor desta primeira parte começou-a pela "Estrutura geológica do território", dando-lhe um desenvolvimento clássico: depois de uma Introdução com um breve quadro da história geológica da Terra, demorou-se sobre a estrutura do Maciço Hespérico, o soco antigo do Precâmbrico ao Fanerozóico, o Paleozóico e o orógeno varisco, o Mezozóico e a abertura do Atlântico, a sedimentação cenozóica, a tectogénese alpina e o relevo da Península Ibérica.

Na sequência, o segundo capítulo foi preenchido com a "Geomorfologia do Maciço Antigo" português, extremidade ocidental do Maciço Hespérico, uma das unidades morfoestruturais a que se associam extensas superfícies de aplanação com os seus relevos residuais, alguns deles de origem tectónica. Dadas as grandes áreas de afloramentos de rochas graníticas e xistentas, atenção especial mereceram as características particulares dos seus modelados, seguindo-se sínteses do relevo regional, do Norte da Beira, de Trás-os-Montes e Minho, de Portugal central, do Alentejo, faltando apenas, a meu ver, o do Algarve, ainda que no capítulo seguinte fosse incluída a parte do Barrocal.

No terceiro capítulo, "Geomorfologia das Bacias Sedimentares", o autor preferiu tratar em conjunto "a caracterização geomorfológica das Orlas Sedimentares mesocenozóicas do Maciço Antigo e também da bacia sedimentar cenozóica do Tejo-Sado", começando pelo exemplo dos relevos de costeiras a norte de Lisboa, de Loures e Bucelas, e depois os modelados em estruturas enrugadas e falhadas, citados os casos já clássicos da serra da Arrábida e do Maciço Calcário Estremenho, e ainda os do Maciço de Sicó e do Barrocal algarvio. Predominando rochas calcárias, associadas a outras de grande elasticidade, nomeadamente argilosas, não podia deixar de haver, por um lado, notícia sobre os vales diapíricos e, por outro, sobre as formas cársicas, de que Portugal tem um rico mostruário em várias partes da sua Orla Sedimentar, sobretudo no Maciço Calcário Estremenho. O capítulo termina com o relevo da bacia sedimentar Tejo-Sado, "a unidade morfoestrutural mais recente do País, e, por isso mesmo, a menos afectada pelas deformações tectónicas", aproximadas "pelas características geomorfológicas, e, até, geográficas".

No capítulo seguinte, dedicado às ilhas e à sua "Geomorfologia vulcânica", depois de uma "Introdução" as alíneas são as seguintes: tectónica e vulcanismo dos Açores, etapas da estruturação das ilhas açoreanas, geomorfologia das ilhas, com amplas notas sobre cada uma delas, e depois, de forma idêntica, Madeira e Porto Santo. O vulcanismo volta a ser abordado em capítulo sobre "Dinâmica actual e recente".

Note-se que, até aqui, predominou a apresentação de formas de relevo intimamente ligadas às estruturas geológicas, que a erosão, tomada no seu sentido mais amplo, decalcou. No seguimento vêm, pelo contrário, as que têm sido predominantemente cinzeladas pelos complexos processos erosivos, ligados não só à variabilidade das condições climáticas e dos cobertos vegetais mas também às actividades antrópicas. Assim, no quinto capítulo, "Formas de relevo e dinâmica quaternária", depois de uma pequena introdução sobre a originalidade do Quaternário na história da Terra, foram sintetizadas as suas características gerais em Portugal, cujo território "esteve sujeito a um regime tectónico de levantamento, o que significa que, nele, nos últimos dois milhões de anos, a erosão predominou largamente sobre a sedimentação". Não obstante, o autor começou pelos depósitos, a partir das rañas, procurando apresentá-las de maneira "mais sistematizada, de modo a tentar definir o significado paleogeográfico [...] e ver em que medida eles podem constituir uma referência estratigráfica de separação entre o Neogénico (fim do Terciário) e o Quaternário". Num esquema já clássico, vêm de seguida os terraços e a organização dos sistemas fluviais (aspectos teóricos sobre a origem dos ter- 
raços, sua existência e características em Portugal, organização geral da drenagem), a plataforma litoral e as praias quaternárias (sempre do geral para Portugal), o seu escalonamento, e efeitos da transgressão flandriana.

O Quaternário foi marcado por oscilações do nível dos oceanos, relacionadas com o ritmo de glaciações. Portugal, pela sua posição geográfica e pelo facto de não ter maciços orográficos de grande altitude, como sucede nos Alpes e congéneres - no continente, a serra da Estrela tem apenas $1991 \mathrm{~m}$ de altitude, que é ultrapassada pela do Pico (ilha do mesmo nome), com 2 345m -, não teve calotes glaciárias nem glaciares maciços e extensos. No entanto, não deixa de haver importantes manifestações da dinâmica glaciária e crionival (arrefecimento plistocénico), cujas formas de relevo e depósitos têm merecido estudos recentes de pormenor.

O capítulo sexto, "Dinâmica recente e actual", teve como abertura os fenómenos vulcânicos, natureza e ritmo das erupções, vulcões activos e potencialmente activos. Foram escolhidos abundantes exemplos açoreanos, referidas as erupções desde meados do século XVI, registadas em documentos dos primeiros tempos da ocupação das ilhas, até à erupção submarina da Serreta, ao largo da Terceira, em 1998/2001. O seguimento foi dado aos fenómenos sísmicos, com algumas informações sobre a sismicidade no continente e a fronteira das placas tectónicas Açores-Gibraltar, a sismicidade e sismotectónica no continente (sem esquecer o célebre terramoto de 1755) e nos Açores, sendo as da Madeira e Porto Santo quase irrelevantes, e terminou com breve nota sobre o sismo de Julho de 1998 que afectou sobretudo uma parte do Faial, São Jorge e Pico. O quadro de alterações e movimentos sensíveis e por vezes destrutivos da superfície terrestre não ficaria completo sem a abordagem de fenómenos tão importantes como os de perigosidade geomorfológica: movimentos resultantes da instabilidade de vertentes fluviais e arribas litorais (quedas de materiais por gravidade, deslizamentos e escoadas), os efeitos da erosão hídrica dos solos (ravinamentos) e daquelas promovidas pelos incêndios e pelas actividades humanas, com exemplos regionais e locais de perturbação do equilíbrio ecológico. O mais grave está em que contribuem para o aumento da desertificação de áreas rurais, no sentido duplo do termo: erosão dos solos e êxodo populacional.

Catarina Ramos contribuiu com uma parte sobre a dinâmica fluvial (os rios como agentes modeladores, as lezírias do Tejo, a influência das barragens) e Maria Eugénia Moreira sobre a dinâmica dos sistemas litorais (geossistemas de arriba, de praia e dunares, fluviomarinhos - estuários e deltas, os de costa lagunar) e o impacte das catástrofes naturais, relacionadas com fenómenos climáticos (tempestades), sísmicos, artificiais (marés negras, pelos derramamentos de crude) e de ocupação humana.

Coube a Denise de Brum Ferreira a responsabilidade da segunda e da terceira partes, "O espaço atlântico oriental" e "O ambiente climático". Relativamente à primeira, a autora teve razão em recordar, na Introdução, que "a geografia e o passado histórico de Portugal estão intimamente ligados ao oceano", que "pela sua posição de finisterra, na fachada ocidental da Península Ibérica, o território nacional contacta directamente com o Atlântico Norte ao longo de cerca de $850 \mathrm{~km}$ de costa" e que, "projectado sobre os arquipélagos dos Açores e da Madeira, o mar português avança numa distância de mais de $2000 \mathrm{~km}$, para oeste, e de $1000 \mathrm{~km}$, para sul". Assim, "território de dimensão reduzida, Portugal possui, no entanto, a maior Zona Económica Exclusiva (ZEE) da União Europeia, com cerca de 1,7 milhões de quilómetros quadrados, ou seja, uma área dezoito vezes superior à sua extensão terrestre".

O facto de não ter sido usual, em obras anteriores de Geografia de Portugal, a apresentação aprofundada, dinâmica e actualizada de dados sobre o oceano, cuja impor- 
tância ficou bem assinalada, leva-me a demorar sobre esta parte do volume. Depois da Introdução, com algumas notas sobre a evolução dos estudos oceanográficos e os meios utilizados, até aos conhecimentos mais actuais conseguidos pela interpretação de dados recolhidos por sensores de tecnologia sofisticada transportados em satélites de vários tipos e trabalhados em agências que os controlam, abrem-se três capítulos - "A dinâmica do Oceano", "Hidrologia e dinâmica do mar português", e "Ambiente oceânico e recursos biológicos", mais duas páginas e meia de bibliografia, em que as matérias são apresentadas com rigor científico, mas em que se nota, como sucede em todo o volume, a preocupação de uma escrita clara de modo a tornar-se inteligível, quer para aqueles leitores que não sejam especialistas, quer para os que estejam menos informados e actualizados.

Assim, no primeiro capítulo a autora preocupou-se com as propriedades da água oceânica (consequências da salinidade, identificação das massas de água e os contactos entre elas), os processos que definem as propriedades e dinâmica dos oceanos (controlos da salinidade e da temperatura - aspectos do balanço energético oceano-atmosfera, sobretudo no Atlântico Norte) e os que geram o movimento da água (giros e turbilhões, circulações costeiras).

No segundo capítulo, sobre a "Hidrologia e dinâmica do mar português", mantendo a originalidade do anterior, foram relevadas as características topográficas dos fundos submarinos do mar português (a dorsal médio-atlântica, as planícies abissais, os montes submarinos, a margem continental), a renovação das ideias sobre a hidrologia regional, a corrente dos Açores (suas características gerais e origem), a água modal madeirense, o sistema de correntes ao longo da costa portuguesa (regimes de Inverno e de Verão das correntes da margem oriental, upwelling durante o Verão e circulação das águas costeiras no Algarve durante a mesma estação, a entrada de água do Mediterrâneo no Atlântico) e uma conclusão sobre a originalidade da dinâmica da bacia do Atlântico oriental, sublinhando-se que "os fenómenos hidrológicos que nascem e evoluem no Atlântico oriental entre a Península Ibérica, os Açores e a Madeira não resultam da corrente do Golfo", pois "a chave da interpretação da circulação e da hidrologia das camadas superiores do Atlântico subtropical oriental é a corrente dos Açores, que acompanha uma frente de dinâmica complexa separando dois tipos de água de densidade diferente".

O terceiro capítulo, "Ambiente oceânico e recursos biológicos", constitui uma espécie de guia de aplicação do aprofundamento dos conhecimentos oceanográficos, um alerta a cuidados que exigem a exploração e a conservação dos recursos biológicos, assunto da maior importância, em face das consequências negativas da exploração desregrada dos recursos terrestres. Chave mestra do pensamento científico da autora foi sublinhada na "interacções entre a água oceânica e a atmosfera suprajacente ou da própria dinâmica do oceano", com importantes influências "na produção de biomassa fitoplanctónica, base da diversidade e abundância da vida marinha, e, em última análise, na valorização da ZEE para a actividade piscatória". O capítulo inclui a organização da vida no oceano, a zonagem dos ambientes marinhos, os avanços do conhecimento devido à teledetecção por satélites, as tentativas recentes de delimitação dos ecossistemas marinhos (propostas de vários investigadores), biomassa planctónica e produtividade primária no mar português (produção de fitoplâncton e ritmo sazonal, produtividade total média anual, reforços locais de produtividade no mar alto - o papel dos ecótomos), recursos piscatórios e dinâmica do ambiente oceânico na ZEE nacional (declínio das capturas de pequenos pelágicos e a dinâmica do ecossistema costeiro oriental, migração dos tunídeos). 
Tal como mencionei anteriormente, Denise de Brum Ferreira também teve a responsabilidade da terceira parte do volume, "O Ambiente climático". No início da Introdução defendeu que "no estudo do ambiente físico, a dinâmica da atmosfera e o clima são factores importantes a considerar, porque têm uma influência determinante sobre as características das paisagens, sobre os modos de vida, a saúde e o bem-estar das populações, e imprimem a sua marca em vários ramos da actividade económica, criando potencialidades, introduzindo factores limitantes, limiares de tolerância, necessidades de adaptação". Em notas breves apresentou dados sobre a evolução dos estudos de clima na Península Ibérica e em Portugal, a rede de pontos de observação, a utilização de satélites, antes da abordagem das matérias contidas em três capítulos: "As condições genéticas do clima", "As características do clima de Portugal" e "O clima de Portugal estará a mudar?", e ainda três páginas e meia de bibliografia.

No primeiro capítulo, os "principais factores que permitem elaborar uma diferenciação climática" começaram a ser apresentados à escala planetária (posição em latitude e ritmo da radiação solar, posição do território português na circulação atmosférica geral - o estudo dos elementos desta circulação através do METEOSAT e a originalidade da posição do espaço português -, modalidades da circulação de Oeste circulação zonal rápida, modalidades de escoamento do ar em circulação meridiana), importância dos tipos de circulação em altitude para o tempo e o clima de Portugal continental e das ilhas; depois à escala regional (Portugal continental na fachada ocidental da Península Ibérica - posição e dimensão, aberto a todas as massas de ar, e marcas da continentalidade, a proximidade do continente africano, a atmosfera marítima - marcas da oceanidade, ambientes climáticos insulares e estratificação vertical do ar); e ainda à escala local (efeito das massas de relevo - distribuição delas, efeitos mecânicos sobre o escoamento das massas de ar) e no caso da escala local não foi esquecido o efeito antrópico, com o exemplo do que sucede em áreas urbanizadas, nomeadamente a deterioração climática na região de Lisboa.

O segundo capítulo, "As características do clima de Portugal”, cujo conhecimento "é fundamental para se perceber as suas paisagens, o quadro de vida dos seus habitantes, antes de se proceder a qualquer tentativa de ordenamento e de uso sustentado do território", foi desenvolvido através de: a radiação solar e a insolação (distribuição da primeira e características da segunda no continente e nas ilhas), os contrastes térmicos (o ambiente invernal e os ambientes térmicos estivais, variedade dos regimes térmicos, extremos térmicos no Inverno e no Verão e situações meteorológicas associadas), distribuição e ritmo das chuvas em Portugal continental, nos Açores e na Madeira (repartição espacial média anual e os regimes pluviométricos), extremos diários das precipitações, os sistemas chuvosos e a variabilidade interanual do regime pluviométrico (grandes depressões migradoras de escala sinóptica, depressões do Atlântico subtropical oriental, actividade pluviosa das correntes perturbadas, tempestades ciclónicas, depressões nascidas entre os Açores e as Canárias, e ciclones tropicais do final do Verão e do Outono nos Açores), a aridez e as secas (definições, regionalização da aridez em Portugal continental e identificação das secas, as secas nas ilhas), as regiões climáticas do território continental (fundamentos da divisão em regiões, climas regionais), zonagem climática das ilhas.

No último capítulo, posto na interrogativa, "O clima de Portugal estará a mudar?", foram examinadas as causas globais externas e as internas, e as ligadas com actividades humanas (perigosidade das emissões de $\mathrm{CO}_{2}$ e outros gases para a atmosfera; Quioto e os problemas políticos, etc.) relacionadas com a "variabilidade interanual do clima 
com vagas de calor e de frio, secas ou, pelo contrário, com episódios de chuvas muito abundantes". Contidos no capítulo ficaram a modelização do sistema climático e a previsão da sua evolução, a dimensão da evolução do clima no século XX a partir dos factos de observação (evolução da temperatura e do regime pluviométrico), os mecanismos da variabilidade do clima na bacia do Atlântico Norte e na Península Ibérica (o primeiro modo de variabilidade do clima mundial: ENSO/LNSO - El Niño-Southern Oscilation/La Niña-Southern Oscilation - e o primeiro modo de variabilidade do clima no Atlântico Norte: NAO - North Atlantic Oscilation, consequências desta durante as suas fases positivas e as suas fases negativas, o seu ritmo), a previsão da evolução do clima de Portugal no horizonte de 2010 (ordem de grandeza da mudança de temperatura no século XXI e da quantidade e regime da chuva, as incertezas da previsão e as surpresas das retroacções no sistema climático do Atlântico Norte). O nascimento de uma nova "Idade do gelo", talvez antes do final deste século, é uma hipótese que está longe de ser descabida e que tem merecido a atenção de muitos especialistas, juntando o que se sabe do passado (acerca dos paleoclimas) e ao muito que se tem colhido no presente graças aos avanços tecnológicos, nomeadamente das nanotecnologias, que permitem "mergulhar" mais e mais profundamente no cada vez mais pequeno.

Num País ameaçado pela aridez e secas, em cuja parte continental as bacias superiores dos principais rios (Minho, Douro, Tejo, Guadiana) são partilhadas com a vizinha Espanha, "qualquer política de gestão de recursos hídricos deve assentar no conhecimento da distribuição espacial e temporal do recurso água", foi a frase do Plano Nacional da Água, 2001, que Catarina Ramos escolheu para abertura da Introdução da parte da sua autoria, "Os recursos hídricos" (pp. 386-414 e cerca de meia página de bibliografia). O desenvolvimento, depois de algumas breves notas de interesse sobre as políticas de gestão da água, de formação de recursos humanos, sobre a necessidade de modificação de hábitos consumistas, a elaboração de planos nacionais e regionais, e de acordos com a Espanha, ocupou quatro capítulos: "Enquadramento de Portugal no contexto euro-mediterrâneo" (a importância do balanço hídrico na avaliação das potencialidades hídricas naturais, o contraste Norte-Sul - 'países excedentários' e 'países deficitários' em água, o escoamento interno e externo - a dependência de Espanha, e as regiões hidrográficas portuguesas). "Os recursos hídricos superficiais" (o regime dos rios - escoamento superficial e produtividade das bacias hidrográficas, irregularidade, variações estacionais, estiagem, cheias, e diferenciação regional do regime dos rios, barragens e albufeiras - sua importância estratégica) e "Recursos hídricos subterrâneos" (as águas subterrâneas e sua dependência do subsolo, repartição geográfica dos sistemas aquíferos, avaliação das reservas hídricas subterrâneas e dos recursos hídricos renováveis, utilização das águas subterrâneas e sua vulnerabilidade e contaminação). "Recursos hídricos das Regiões Autónomas" (os arquipélagos da Madeira e dos Açores).

A última parte, "A vegetação" (pp. 416-480 e mais cerca de página e meia de bibliografia), com as assinaturas de Maria Eugénia Moreira e Carlos da Silva Neto, relevou o valor considerável do património florístico do continente e das regiões insulares, atribuíveis a várias causas (posição geográfica, mudanças climáticas do Quaternário, barreiras montanhosas, perenidade de hábitos culturais, etc.). A uma "Introdução sobre a fitogeografia de Portugal", seguem-se "A vegetação natural" (florestas caducifólias do Norte e Centro - carvalhais e vidoais, florestas marcescentes do Centro e do Sul cercais da Estremadura, da serra da Arrábida e do Algarve, florestas perenifólias do Sul - sobreirais, azinhais e montados de azinho, zambujais, florestas e formações ripícolas - amiais, freixiais, salgueirais, choupais e ulmeirais, tamargais, e loendrais, florestas 
de coníferas - pinhais, laurissilva insular da Madeira e dos Açores, formações arbustivas - matos; formações vegetais do litoral; disposição em altitude da vegetação das montanhas continentais e insulares). Em "A vegetação introduzida" foram incluídas as espécies alimentares, as industriais, as silvícolas, as medicinais e as ornamentais. A quinta parte terminou com um vasto e valioso elenco florístico, dados os nomes científico e vulgar, de A a Z (pp. 474-480, duas colunas por página).

\section{SOCIEDADE E PAISAGENS}

Quanto ao conteúdo do Segundo volume da Geografia de Portugal o leitor desta Notícia poderá começar por refrescar a memória voltando ao quadro I com os títulos das suas partes e os nomes dos respectivos autores. Não se incluiu o que se refere às cidades, por motivos recordados logo no início desta Notícia. Na "Introdução", os coordenadores, Teresa Barata Salgueiro e João Ferrão, listaram o "turbilhão de mudanças" dos últimos anos, "privilegiando a transformação nas paisagens", designadamente nas cidades, "em articulação com as alterações sociodemográficas", sem deixarem de ter em conta a perspectiva histórica que "ajuda a situar o presente". Isto faz-nos recordar o que Edgar Morin escreveu, em Os sete saberes necessários à educação do futuro (1999), quanto ao facto de ser necessário aos cidadãos do novo milenário, para que possam pensar os problemas do seu tempo, compreender, simultaneamente, a condição humana no mundo e a condição do mundo humano que, no decurso da história moderna, se tornou no da era planetária. Se desde o século XVI se entrou no processo continuado da "mundialização", esta ganhou maior amplidão e aprofundamento no século XX, evidenciada a emergência de um objecto novo, o mundo como tal. Segundo o mesmo autor, "o planeta não é um sistema global, mas um turbilhão em movimento".

Para se ter uma ideia do turbilhão de mudanças à escala global os coordenadores do volume citaram algumas e para o caso português distinguiram as seguintes, aqui reproduzidas com ligeiras modificações: "alteração geoestratégica, com o encerramento do ciclo do império colonial e a adesão à União Europeia"; novo sentido da "posição euro-atlântica" e centralidade no Oceano; "redução muito significativa da agricultura e da indústria, com a transição para uma economia baseada nos serviços"; "modernização das infra-estruturas básicas de mobilidade e saneamento, menos conseguida" em alguns sectores (equipamentos, educação, saúde e protecção social) por força do atraso da "construção social do Estado-providência e ainda mais débil quando emergem as tendências para o seu desmantelamento e privatização dos respectivos serviços; envelhecimento demográfico e inversão do sentido das tendências migratórias dos últimos séculos"; "o regresso à sociedade pluriétnica, que noutras épocas caracterizou o País; e o "abandono progressivo de muitas regiões do interior e o aumento da concentração urbana no litoral, crescimento do nível de vida e dos níveis de consumo, designadamente com a expansão muito rápida da taxa de motorização das famílias e da posse de segunda habitação".

No desenvolvimento das partes e seus capítulos foram referidos outros factores de mudanças. Tratando-se de matérias do domínio da Geografia em que a diversidade humana, cultural, social, económica e política, e a sua variação no tempo e no espaço têm papéis de relevo, não admira que "mudança" seja a palavra-chave em todas as contribuições. De resto, também no primeiro volume, preferida a palavra "dinâmica", o sentido foi praticamente o mesmo. Comparando os dois volumes, notam-se algumas diferenças: no segundo, as regiões autónomas da Madeira e dos Açores, ainda que encar- 
tadas na maioria dos mapas de Portugal com índices, indicadores, etc., não foram apresentadas em textos separados; nessas figuras, dada a escala utilizada, à policromia continental, representativa da variabilidade dos aspectos tratados, correspondeu a monocromia insular; mesmo no capítulo sobre paisagem e identidade não se juntou um único documento fotográfico para mostrar a (enorme) diversidade de paisagens insulares; são raras as listas bibliográficas no fim de capítulos.

A primeira parte do segundo volume, "Evolução histórica e ocupação do território" (pp. 16-45 e um pouco mais de uma página de bibliografia) contém dois capítulos, ambos da autoria de Carlos Alberto Medeiros, o primeiro sobre os primórdios da evolução de Portugal, a expansão marítima e os seus reflexos, com a preocupação de sublinhar "alguns aspectos da evolução histórica do país que interferem com a compreensão da sua geografia humana"; e o segundo sobre os novos desafios do século XIX, sobretudo depois da independência do Brasil, a coroa de glória do espaço ultramarino, e a evolução demográfica até ao primeiro recenseamento (1864), "elemento importante de uma conjuntura nacional" caracterizada por mudanças importantes. De uma forma sóbria o autor traçou os quadros da situação quase marasmática de uma "monarquia agrária" medieval num país pouco povoado e periférico, para o do turbilhão da viragem para o exterior no século XV, isto é, dessa saga das descobertas e exploração de mundos novos que tanto revolucionaram o conhecimento medievo da Terra, iniciando o roteiro pelas experiências e sequências da ocupação humana de ilhas despovoadas, nos arquipélagos da Madeira, dos Açores e depois de Cabo Verde, os contactos com povos e culturas da costa de África, a passagem do Atlântico para o Índico e o encontro da Índia fabulosa e de outras terras, a travessia do Atlântico Sul e o Brasil até então de todo desconhecido pelos europeus.

Encerram o primeiro capítulo algumas notas sobre os séculos XVII e XVIII, acerca das interferências da Inglaterra (referências ao Tratado de Methuen e ao desenvolvimento da cultura da vinha no Alto Douro) e do Brasil ainda como elemento basilar do império português. Tendo sido referidos dois acontecimentos importantes do tempo do Marquês de Pombal, pena é que não se juntasse o relativo às reformas educativas, como as do ensino superior, e culturais por ele promovidas. No segundo capítulo foram tratados os factos significativos do século XIX e as interpretações divergentes, e sobretudo a evolução demográfica, concluindo com duas notas breves sobre a evolução recente, até à entrada de Portugal na CEE, depois do 25 de Abril de 1974, e a integração na União Europeia.

"População e território" é o título da segunda parte, em que colaboraram João Ferrão, Isabel Margarida André, Jorge Macaísta Malheiros, Teresa Sá Marques e Teresa Pinto Correia. Em vista da dimensão, variedade e número de autores, julgo benéficas as referências do quadro II.

Quadro II - Capítulos e autores de parte do volume II Table II - Chapters and authors of the second part of volume II

\begin{tabular}{llr}
\hline \multicolumn{1}{c}{ Capítulos } & \multicolumn{1}{c}{ Autores } & Pág. \\
1. Dinâmicas demográficas: uma visão panorâmica & João Ferrão & $50-71$ \\
2. Família e género & Isabel M. André & $72-86$ \\
3. Migrações & Jorge M. Malheiros & $87-124$ \\
4. População, qualificações e capital cultural & J. Ferrão e T. Sá Marques & $126-140$ \\
5. Desenvolvimento humano e coesão social & Isabel M. André & $141-150$ \\
6. Paisagem e identidade: da memória à pós-modernidade & Teresa Pinto Correia & $151-167$ \\
\hline
\end{tabular}


João Ferrão, depois de uma "Introdução", arrumou as matérias por temas, alguns dos quais em forma de desafios, como a evolução temporal das dinâmicas: a dupla convergência, subdividida em três fases (finais do século XIX/anos 50 do século XX, o arranque tardio da transição demográfica; início dos anos 60/começo dos anos 90, a concretização tardia do processo de modernização demográfica; e meados dos anos 90actualidade, a caminho de um modelo demográfico europeu comum?) e o assunto continua com futuro (meados do século XXI), por fim, um membro incontestado do clube de modelo demográfico europeu comum? Passando à evolução espacial das dinâmicas demográficas, o reforço das assimetrias territoriais, definiu a transição como um processo a várias velocidades..., debruçou-se sobre as espacialidades da mudança demográfica, reconfigurações e assimetrias, para terminar com modernização demográfica, uma leitura de síntese.

Muito ligado a este primeiro capítulo está o quarto, "População, qualificações e capital cultural", assinado por João Ferrão e Teresa Sá Marques. Em cerca de catorze páginas, com vários mapas, fotos e quadros de grande dimensão, a população em geral foi apresentada em estádio de qualificação acelerada mas insuficiente, examinadas características da população activa (desemprego, feminização, envelhecimento), do que chamam "bacias de emprego" (duas metrópoles, Lisboa e Porto, a primeira, com um raio de influência nacional, mais madura que a segunda, e diversas cidades médias; sistemas policêntricos ou lineares de âmbito sub-regional; pequenos centros com um raio de influência de proximidade; e municípios caracterizados pela ausência de fluxos intermunicipais significativos, e mobilidade geográfica como condição de acesso ao mundo do trabalho - êxodo rural, movimentos pendulares, mobilidades cruzadas, etc.), os territórios como contextos de qualificação e capacitação humana, e Portugal, um longo caminho por percorrer.

O quadro geral do país é nitidamente desolador. Duas frases, uma do início e outra do fim do capítulo, que dizem praticamente o mesmo, exprimem o que quero dizer: "apesar das melhorias observadas nas últimas décadas, nomeadamente como consequência do alargamento do período de escolaridade obrigatória e da democratização do acesso ao ensino superior, a população portuguesa continua a deter baixos níveis de instrução e qualificação por comparação com os países mais desenvolvidos"; e "apesar das melhorias indiscutivelmente observadas nas últimas décadas, a sociedade portuguesa continua a deter baixos índices de qualificações e de capacitação humana, ou seja, de capital cultural, no contexto europeu".

Embora me considere um optimista convicto, não posso deixar de definir a situação como preocupante, em face da célebre "Estratégia de Lisboa", documento longo e minucioso gizado quando Portugal teve a Presidência da União Europeia e o apresentou em reunião magna de Lisboa, em 2000. Os 15 membros de então assumiram fazer da União, até 2010, "a economia baseada no conhecimento" (o itálico é da minha responsabilidade) "mais dinâmica e competitiva do mundo, capaz de garantir um crescimento económico sustentável, com mais e melhores empregos e com maior coesão social". Constituiu um projecto demasiado ambicioso, perante os imensos desafios que já se anunciavam e o tempo confirmou e ampliou: alargamento da União a países de fraco desenvolvimento e carecidos de importantes alterações económicas e sociais (a maior parte deles saídos de regime comunista), fraqueza de crescimento económico mesmo nos mais ricos, problemas relacionados com a dependência continuada de uma fonte energética extra-europeia (o choque do petróleo), aumento do desequilíbrio das contas públicas e do desemprego, caminho lento e difícil para a coesão social, dúvidas 
quanto à aceitação geral de uma Constituição para toda a União. E o mais grave é que tudo isto era visto (e continua) em termos de diminuir o fosso económico entre a Europa e os EUA, e em alguns casos o Japão, e por vezes o temor dos desafios igualmente competitivos dos países emergentes como a China, a Índia e outros do sueste asiático. A data limite de 2010 já teve de ser prorrogada.

$\mathrm{Na}$ altura em que redigia esta longa Notícia sobre os dois primeiros volumes da Geografia de Portugal, no caderno Fórum Empresarial do jornal diário Público, dedicado a "Ciência e Tecnologia", de 17 de Abril de 2006, com o subtítulo de "Inovação. Futuro do País depende da I\&D”, a propósito do tão badalado Plano Tecnológico Nacional, apesar de um sopro de optimismo, reconhecia-se que Portugal surgia "continuamente na retaguarda dos índices de inovação, o que, evidentemente, penaliza o País no caminho da sua modernização e do seu próprio crescimento". Podendo ser acusado de ter retirado a frase do seu contexto, todavia, por mais voltas que sejam dadas, ela traduz uma realidade que nos preocupa a todos e que foi evidenciada por João Ferrão e Teresa Sá Marques. E dias depois, três documentos de análise da situação portuguesa, de origens diferentes, um do Banco de Portugal, outro da Organização para a Cooperação e Desenvolvimento Económico (OCDE) e outro do Fundo Monetário Internacional (FMI), coincidiam no diagnóstico negativo e no aconselhamento de medidas a tomar, entre as quais têm relevo, sobretudo na avaliação do segundo organismo, as de melhoria da "educação, da formação e da qualificação" do capital humano porquanto o País "tem um atraso considerável" em relação às médias europeias.

O segundo e o quinto capítulos do segundo volume, "Família e género" e "Desenvolvimento humano e coesão social", ficaram a dever-se a Isabel Margarida André, notável pelo didactismo das definições de tipos de situações caracterizantes das alterações da instituição familiar, sob a influência de factores internos e externos, da "reconfiguração das relações de género" e da coesão social, destacando transformações mais relevantes, vistas no plano global e no plano regional. Também aqui, a simples transcrição dos títulos e subtítulos acordará, certamente, a curiosidade e o desejo de informação dos leitores. Sob a rubrica de "Estruturas familiares em mudança: na encruzilhada entre autonomia individual, a centralidade dos afectos e a instabilidade dos laços", encontrará o leitor informações do maior interesse sobre sexualidade, conjugalidade e procriação - práticas dissociadas, relações do género mais equilibradas (dupla desinstitucionalização da conjugalidade; dissociação entre casamento e procriação; parentalidades desejadas e planeadas; uma geografia de síntese); e um percurso sinuoso pela igualdade de oportunidades e pela equidade social entre homens e mulheres (relações de género formatadas entre a repressão, a guerra colonial e as migrações; novos valores e novas práticas - o caminho da igualdade de oportunidades, vistas através da família, do emprego, nos campos da mobilidade, da disponibilidade e das qualificações, e ainda da cidadania), acreditando que serão enfraquecidas "as resistências mais conservadoras" e acelerados "os percursos da igualdade de oportunidades entre mulheres e homens".

Nas nove páginas e meia do quinto capítulo, explicada a razão da introdução do conceito de "desenvolvimento humano" pelas Nações Unidas (além das dimensões económica, as de bem-estar e desenvolvimento social e cultural), no seu Programa para o Desenvolvimento (PNUD), e não apenas de desenvolvimento ligado somente ao crescimento económico, foi feita "uma breve discussão das diversas dimensões analíticas do desenvolvimento na óptica da coesão social" através de duas perspectivas: evolução rápida nas últimas quatro décadas, e maiores vulnerabilidades do desenvolvimento 
humano (pobreza, défice de qualificações e info-exclusão, cidadania e participação), para chegar, muito ao gosto da autora (no segundo capítulo, por exemplo, os três tipos de transformações mais relevante, os três "países" de acordo com indicadores de conjugalidade e de fecundidade, os cinco grandes tipos de estruturas familiares), a cinco tipos do desenvolvimento humano pela utilização de seis dimensões de análise, sendo quatro de integração (familiar, social, escolar e no mercado de trabalho) e os outros de condições de alojamento e de rendimentos, com os respectivos indicadores, referidos a 2001.

O dinamismo da evolução populacional e as grandes transformações recentes (sobretudo após 1974) foram os temas escolhidos para o terceiro capítulo, sobre "Migrações", de Jorge Macaísta Malheiros. Aspecto relevante está no facto de Portugal, que fora um país de emigrantes, ter passado a ser um receptor de imigrantes, sendo analisados os factores de explicação das duas situações e a passagem de uma à outra. $\mathrm{Na}$ última parte do capítulo o autor também se referiu aos percursos e tendências dos não menos importantes movimentos migratórios internos. Mas as ligações com o exterior, num e noutro sentido, mereceram o maior desenvolvimento.

Interessante a "análise comparativa da geografia contemporânea do retorno" e a definição de três padrões distintos, o "francês", o "alemão" e o "americano", e dos critérios de caracterização das comunidades imigradas. Em "A afirmação de um país de imigração" foram sublinhadas diferentes fases, que assinalo resumidamente. A primeira dominada pelos africanos, marcada, desde meados dos anos 60, pela vinda maciça de caboverdeanos, numa altura de seca nas ilhas, fenómeno de causas climáticas sahelianas que se tem repetido ao longo do séculos, com as necessidade de mãode-obra em Portugal numa época de sangria de nacionais, sobretudo jovens, enviados para as guerras coloniais (Guiné, Angola e Moçambique), mas o grande boom esteve ligado, sem dúvida, com a descolonização dos antigos territórios ultramarinos e as lutas internas em Angola e Moçambique que trouxeram, a par dos inúmeros ditos "retornados", muitos outros. Nos anos 80 juntaram-se os asiáticos (sobretudo indianos, paquistaneses e chineses) e os sul-americanos (designadamente brasileiros); e nos finais do século passado, depois da queda do regime comunista e desmembrado o império soviético, foi a entrada maciça de gente do Leste da Europa, sobretudo ucranianos, dotados de níveis médios de instrução mais elevados do que os africanos, asiáticos ou sul-americanos.

Estas ondas imigratórias tiveram consequências sociais, económicas e até paisagísticas importantes. Por exemplo, Lisboa e a sua região mostram-se, à evidência, como um caleidoscópio racial, cultural e económico. Portugal foi-se tornando, cada vez mais, um país pluriétnico e de entrosagem de culturas. Nos seus espaços, sobretudo nos metropolitanos, coexistem indivíduos de várias origens, culturas e línguas; nalguns bairros "ghetizam-se" populações da mesma origem ou aparentadas, associadas a fenómenos de info-exclusão económica e social; na mesma área ou em áreas próximas podem estar a igreja católica, a ortodoxa, a sinagoga, a mesquita, o templo hindu ou budista, os centros de várias correntes religiosas de origens norte-americanas. Numa figura, sobre um mapa-mundo, o autor resumiu a participação do país em três sistemas migratórios distintos, caracterizados ainda em pequenas notas escritas: da antiga e consolidada estrutura emigratória euro-americana (no que toca à dispersão geográfica "seis países concentram cerca de $80 \%$ da diáspora portuguesa no exterior" - EUA, Canadá, Venezuela, Brasil, África do Sul e França); dos movimentos imigratórios ligados aos países lusófonos; e das vagas recentes e dinâmicas a partir de países da Europa oriental. 
Ao referir-se à importância e significado do sistema assente nos países lusófonos, e uma vez que em locais anteriores procurou dar imagens das transformações geográficas no País ligadas à distribuição dos seus imigrados, é pena que Jorge Malheiros não tivesse acrescentado umas linhas sobre a CPLP (a Comunidade de Países de Língua Portuguesa), organismo ainda por vezes balbuciante, mas que abarca países tão diferentes como o pequeno Portugal no extremo atlântico da Europa, progenitor colonial do Brasil subcontinental na América do Sul, de cinco países na África, dois pequenos arquipélagos e três continentais de tamanhos diferentes, um dos quais na margem do Índico, e ainda do insular e longínquo Timor entre a Indonésia e a Austrália. Diferem uns dos outros, mas todos eles defendem uma língua, a portuguesa. Com as suas colónias fixadas noutros países gerem esse sentimento de unidade dado pela utilização de língua comum, ainda que com as suas várias modulações: é o espaço vasto da lusofonia. Mutatis mutandis, podem ser aqui recordadas algumas afirmações de Serge Arnaud et al., em Les défis de la francophonie. Pour une mondialisation humaniste (2005): "de observador e de testemunha tímida", a Lusofonia, como a Fancofonia, "deve transformar-se em actor potente e exemplar na cena mundial"; formar "uma Comunidade verdadeira, actor maior da mundialização, afirmando o seu papel de espaço geocultural de solidariedade e de diálogo de culturas".

Para o sexto capítulo, como já referi anteriormente, Teresa Pinto Correia escreveu "Paisagem e identidade: da memória à pós-modernidade". São suas alíneas, uma introdução em que são citados diversos autores, incluindo Orlando Ribeiro; e outra de enquadramento conceptual, também com recurso a informações bibliográficas, para maiores demoras acerca de estudos originais, recentes e menos recentes, relativos a tipos e unidades de paisagens em Portugal continental (revalorizados os trabalhos de Orlando Ribeiro e o seu mapa das regiões geográficas, de 1945) e exemplos de identidade na gestão actual da paisagem portuguesa. Em conclusão a autora sublinhou a variedade de paisagens e de factores da sua sustentabilidade, e acrescentou a necessidade da "ponderação das várias questões que se põem em cada paisagem". Só depois deste capítulo aparece a lista bibliográfica dos que compõem a segunda parte (pp. 169173).

\section{À MANEIRA DE EPÍLOGO PARCIAL}

Repito o que já escrevi anteriormente: as minhas Notícias tinham de ser longas porque só assim podia relevar, jure optimo, o riquíssimo conteúdo científico e informativo desta Geografia de Portugal, original, diferente de outras, também notáveis, mas de épocas anteriores. Introduzi algumas notas resultantes da minha própria reflexão, que traduzem, tanto quanto possível, a leitura cuidada dos textos, a observação atenta de quadros estatísticos, de gráficos, da ilustração fotográfica e cartográfica.

O mesmo poderei um dia dizer dos volumes III - Actividades Económicas e Espaço Geográfico, 462 páginas, e IV - Planeamento e Ordenamento do Território, 471 páginas, ambos profusamente ilustrados, coordenados, respectivamente, por Carlos Alberto Medeiros, por Jorge Gaspar e José Manuel Simões, de que, por ora, dou apenas, de maneira corrida, os títulos das diferentes partes. No primeiro são: Actividades Rurais; A Floresta, na Memória e no Futuro do Espaço Rural; A Pesca; Energia; As Actividades Industriais; Os Serviços; O Comércio Retalhista: da Oferta de Bens às Experiências de Vida; Os Transportes; O Turismo e as Novas Dinâmicas Territoriais; e Envolvimento 
Económico Internacional: Comércio e Investimento. No segundo incluem-se Portugal: Território e Planeamento; Administração e Infra-estruturação do Território; Planeamento e Desenvolvimento; Ordenamento do Território; Expansão, Reabilitação e Renovação Urbana: Lições de Experiência; e Conclusões e Perspectivas.

Esta Geografia de Portugal é, sem dúvida, uma obra de referência importante, não só para os geógrafos mas também para todos os que queiram aprofundar os seus conhecimentos sobre temas e problemas do País, do passado e do presente, e pensar no que poderá vir a suceder em anos vindouros. Feita com rigor científico, por todo o lado transparecem as preocupações dos autores dos textos, universitários de méritos reconhecidos, com o uso de uma escrita acessível e equilibrada. 



\title{
LA INVESTIGACIÓN EN GEOMORFOLOGÍA PERIGLACIAR EN ESPAÑA Y PORTUGAL. EVOLUCIÓN RECIENTE Y ESTUDIOS ACTUALES
}

\author{
Antonio Gómez OrTiz ${ }^{1}$ \\ Gonçalo T. VieIRA ${ }^{2}$
}

\begin{abstract}
Resumen - Se hace una revisión de la producción científica reciente por parte de autores españoles y portugueses en temas de geomorfología periglaciar a partir de las publicaciones del grupo de trabajo IPA-España. Su valoración crítica permite explicar la evolución de este conocimiento disciplinar (ideas, conceptos, métodos, ámbitos y temas de estudio y grupos de investigación) en el contexto del progreso que la Geomorfología ha venido experimentando en ambos países. Acontecimientos significativos en todo ello fueron la creación de la Sociedad Española de Geomorfología (SEG), en 1987; el Grupo Español IPA-España, en 1994, y el Grupo Portugués IPA-Portugal, en 2005, ambos inmersos en la International Permafrost Association.
\end{abstract}

Palabras clave: Geomorfología periglaciar, estudios recientes, España, Portugal.

Resumo - A INVESTIGAÇÃo EM GEOMORFOLOGIA PERIGLACIÁRIA EM ESPANHA E Portugal. Evolução ReCENTE E EStudos ACtuAis. Apresenta-se uma síntese dos trabalhos recentes de autores espanhóis e portugueses no âmbito da geomorfologia periglaciária. O levantamento efectuado baseia-se na análise crítica (ideias, conceitos, métodos, áreas e temas de estudo e, grupos de trabalho) das publicações do grupo de trabalho IPA-Espanha. Esta é enquadrada no contexto dos progressos que os estudos de Geomorfologia vêm experimentando em ambos os países, de modo a explicar a evolução científica recente. Os principais marcos na evolução dos estudos de periglaciarismo na Península Ibérica são a criação da Sociedade Espanhola de Geomorfologia em 1987, do grupo espanhol da International Permafrost Association em 1994, e do grupo português da mesma associação em 2005.

Palavras-chave: Geomorfologia periglaciária, investigação recente, Espanha, Portugal.

Abstract - Research on Periglacial geomorphology in Spain and Portugal. TRENDS AND CONTEMPORARY STUDIES. An analysis of the scientific literature on

1 Área de Geografía física y Servei de Paisatge de la Universidad de Barcelona. E-mail: gomez@ub.edu

2 Investigador do Centro de Estudos Geográficos e Professor Auxiliar da Faculdade de Letras da Universidade de Lisboa. E-mail: gtvieira@ceg.ul.pt 
periglacial geomorphology produced by Spanish and Portuguese researchers is presented. The paper is based in the proceedings of the meetings of the IPA-Spain group. The critical evaluation of these publications allows explaining the evolution of Iberian periglacial geomorphology (i.e. ideas, concepts, methods, regions of study, themes and research groups) in the context of the evolution that Geomorphology as a science is facing in both countries. Given this framework, the more significant events that occurred were the founding of the Spanish Society of Geomorphology (SEG) in 1987, of the Spanish Group of the International Permafrost Association (IPA-Spain) in 1994, and of the Portuguese Group (IPA-Portugal) in 2005.

Key words: Periglacial geomorphology, recent research, Spain, Portugal.

Résumé - LA RECHERCHE EN GÉOMORPHOLOGIE DU PÉRIGLACIAIRE EN ESPAGNE ET AU Portugal. Évolution RÉCENTE ET ÉTUdes EN COURS. On présente la production scientifique récente des auteurs espagnols et portugais dans le domaine de la Géomorphologie du périglaciaire, en se basant sur les comptes-rendus des réunions du Groupe de Travail IPA-Espagne. Leur présentation critique permet de montrer l'évolution des idées, des concepts et des méthodes, ainsi que des thèmes et lieux de recherche qui sont pratiqués par les divers groupes constitués. Les événements les plus significatifs ont été la création de la Sociedad Española de Geomorfologia en 1897, du Grupo Español IPA-España en 1994 et du Grupo Português IPA-Portugal en 2005, ces deux derniers faisant partie de la International Permafrost Association.

Mots-clés: Géomorphologie périglaciaire, recherche, Espagne, Portugal.

\section{ANTECEDENTES}

El interés por el estudio de las formas de relieve asociadas a procesos periglaciares por la comunidad científica ibérica es relativamente reciente. Esta labor podría instalarse a partir de la primera mitad del siglo XX, probablemente como respuesta a la celebración del V Congreso Internacional de INQUA (Madrid-Barcelona, 1957), donde se dio cuenta de la existencia de formas de modelado de origen frío no glaciar en diferentes lugares de la Península Ibérica. La fecha es significativa si tenemos en consideración que la Unión Geográfica Internacional, en su XVI Congreso, celebrado en Lisboa en 1949, creó la Comisión sobre periglaciarismo (Pissart, 1999). Sin embargo, hay que reseñar que mucho antes ya habían sido señalados registros periglaciares. Por ejemplo, en Sierra Nevada (Dresch, 1937), Pirineo central (García Sainz, 1935; Barrère, 1952), oeste de Lisboa (Guilcher, 1949), Macizo Calcário Estremenho (Martins, 1949). $\mathrm{E}$, incluso, por estos mismos años se comenzó a reflexionar sobre el tema, como así lo hizo Floristán (1953), en su librito El modelado periglaciar donde resalta el significado de la morfodinámica de procesos fríos en la definición de muchos de los relieves de latitudes medias bajo condiciones no glaciares. El progreso del conocimiento periglaciar hasta entrada la década de los años 70 del siglo XX fue lento aunque progresivo y se resolvió, sobre todo, en la catalogación, descripción y cartografia de modelados (Peña Monné, 1998). Los autores de estos estudios fueron, en su mayoría, extranjeros y focalizaron esfuerzos en montaña y sectores aledaños (Carvalho, 1955, 1964; Hamelin, 1958; Hempel, 1960; Messerli, 1965; Tricart, 1966; Höllermann, 1967; Brochu, 1969; 
Soutadé y Baudière, 1970; Daveau, 1973; Brosche, 1978; etc). El verdadero aporte científico autóctono se operó en el tránsito de la siguiente década, la de los 80 , y vino influido, muy particularmente en España, por la escuela francesa de Estrasburgo, pues principios, ideas, métodos de trabajo y técnicas cartográficas fueron introducidas a través de Tricart $(1962,1967$, etc.). En Portugal la influencia francesa también fue notoria a través de los trabajos de Carvalho $(1955,1964)$ y Daveau $(1973,1978)$.

\section{EL PROGRESO OPERADO HASTA LA DÉCADA DE LOS AÑOS 80 DEL SIGLO XX}

Fue, por tanto, a partir de finales de la década de los 70 cuando empezó a irrumpir con paso firme en la literatura geomorfológica española y portuguesa lo relativo a las formas de modelado periglaciar centrando atención, sobre todo, en ámbitos montañosos de la Península Ibérica, en especial en Pirineo, Cordillera Ibérica, sierras de Guadarrama-Gredos, serra da Estrela y algunos enclaves de la cuenca del Duero y Tajo, preocupando, particularmente, la evolución de laderas. El interés geomorfológico por las manifestaciones periglaciares pronto se generalizó entre la comunidad de geomorfólogos (geógrafos y geólogos) y el dato más objetivo durante estos tiempos fueron las publicaciones (García Ruiz, 1999) y la irrupción de esta temática en los certámenes científicos sobre cuestiones cuaternarias y geográficas. Al respecto, resulta ya significativa la presencia de comunicaciones de carácter periglaciar en la II. ${ }^{a}$ Reunión del Grupo Español para el Estudio del Cuaternario (Jaca, 1975) y en el V Coloquio de Geografía (Granada, 1976). El comentario que puede hacerse de estos trabajos, en número de 8 y 10, respectivamente, es la preocupación generalizada que suscitan las formas frías no glaciares en la definición del modelado de laderas en montañas de altitud modesta y en algunas, incluso, cercanas a la línea de costa. Esta constatación significó entreabrir el debate, aún vigente, acerca de la magnitud de las condiciones frías pleistocenas en la Península Ibérica, de los procesos desencadenantes y de su resultado en la configuración de los actuales relieves, cuestión, por cierto, ya planteada por Rosselló (1970) para el ámbito mediterráneo y remarcada, de nuevo por él mismo, en la Ponencia que abrió las sesiones del referido Coloquio de Geografía (Rosselló, 1977).

De esta época son también las primeras tesis doctorales sobre procesos fríos en las que sin olvidar la acción glaciar lo relativo a morfodinámica periglaciar ocupó lugar destacado, en ocasiones predominante o, incluso, exclusivo. En tal sentido, merece destacarse la atención que suscitó el Pirineo donde se describieron y explicaron morfologías heredadas y actuales (Serrat, 1977; Gómez Ortiz, 1980; Peña Monné, 1980; etc.) y donde, además, se interpretaron los procesos fríos actuales como agentes muy eficaces y significativos en la definición del paisaje de los niveles supraforestales (Soutadé, 1978). De estos mismos años también fue el conocimiento de modelados periglaciares en las sierras de Peneda y Gerês (Minho-Portugal) (Coudé-Gaussen, 1979).

En semejante línea investigadora el despliegue de artículos publicados en revistas y contribuciones a reuniones científicas por parte de los investigadores españoles y portugueses se incrementó notablemente, ocupando lugar relevante el descubrimiento de formas heredadas y su cartografía precisa tanto en áreas glaciadas como en aquellas otras no glaciadas. La producción científica, abundante en número y temas tratados, incluyó los sistemas montañosos más importantes de la Península Ibérica, aunque ocupando lugar preferente el Sistema Central (Martínez de Pisón y Muñoz Jiménez, 
1972; Sanz Herraiz, 1977; Bullón Mata, 1977; Pedraza Gilsanz, 1978) y el Pirineo (Gómez Ortiz y Serrat, 1977), en el que por primera vez se describen trabajos experimentales de campo en lóbulos de gelifluxión (Creus y García Ruiz, 1977). Destaca también la atención que empezaron a tener aquellas montañas con ligero rastro glaciar o sin él. De éstas caben destacarse el Prepirineo leridano (Solé Sugrañes, 1973), Montseny (Llobet, 1975/76), Moncayo (Pellicer Corellano, 1980), Javalambre (Gutiérrez y Peña Monné, 1975), Alto Maestrazgo (Ginés y Mateu, 1977), Sierra Mágina (García Rossell y Pezzi, 1977), etc. Igualmente sobresale el interés que despertaron las islas Baleares y Canarias describiéndose derrubios periglaciares en laderas de la serra de la Tramontana (Rosselló, 1977) y figuras geométricas actuales en las Cañadas del Teide (Morales et al., 1977). Asimismo mereció atención la Meseta española, pues del valle del Tajuña se analizaron derrubios ordenados (grèze litée) (Asensio Amor y González Martín, 1974), que también se señalaron para el SO de Galicia (Pérez Alberti, 1979). Y por lo que respecta a Portugal destacan los trabajos de Daveau (1973), sobre depósitos periglaciares heredados en las sierras de la Estrela y Lousã (Sistema Central) y Macizo Calcário Estremenho y margen litoral (norte de Lisboa); Rebelo (1975), que se ocupó de las crestas cuarcíticas de Valongo y depósitos asociados; Coudé-Gaussen (1979), acerca de la morfogénesis de origen frío en las sierras de Gerês y Peneda. Igualmente resalta por su novedad las reflexiones que Daveau (1978) hace del significado del frío actual en la morfodinámica del modelado de las montañas portuguesas.

Los resultados logrados hasta finales de la década de los 70 podrían resumirse en las siguientes ideas:

a) Desarrollo generalizado de los procesos fríos no glaciares en el conjunto de la Península Ibérica a lo largo del Pleistoceno;

b) Reparto espacial de formas de modelado periglaciar en montañas con desarrollo de glaciares cuaternarios o sin ellos y su reflejo en el margen litoral cántabro y portugués hasta la latitud de Lisboa;

c) Desarrollo temporal de procesos y formas periglaciares coetáneos y posteriores al glaciarismo, según tipo de montaña y cotas;

d) Interés preferente por el modelado de laderas (derrubios tipo grèze litée y groize);

e) Constatación de procesos periglaciares actuales en Pirineo central y Cañadas del Teide y

f) Preocupación dominante por la descripción de las formas y su cartografía.

\section{INVESTIGACIONES RECIENTES}

Las últimas décadas del siglo XX y los primeros años del XXI, desde 1980, el progreso operado en investigación periglaciar por parte de la comunidad española y portuguesa ha resultado muy notable y ha tenido un desarrollo paralelo a los avances que se han venido registrando en la geomorfología en general (Vieira y Cordeiro, 1998; Ferreira et al., 2000; Gómez Ortiz et al., 2001). El conocimiento de la morfogénesis fría y el número de áreas investigadas ha venido a confirmar la gran extensión que ocupan las formas de modelado frío no glaciar en el conjunto de la Península Ibérica así como la multivariedad de sus procesos desencadenantes. Asimismo se ha puesto de relieve la existencia de un piso periglaciar activo en determinadas unidades geográficas de algunas cordilleras así como la existencia de bolsas de permafrost alpino y funcionalidad de glaciares rocosos. 
El avance operado, siempre avalado por la asunción de nuevos conceptos e ideas, métodos y técnicas por parte de los grupos de investigación implicados, debió resultar de una serie de datos coincidentes, probablemente los mismos que caracterizan a la geomorfología:

a) el contacto con el exterior a través de la participación en programas de actuación internacional y eventos científicos;

b) la mayor comunicación entre disciplinas y entre colectivos con líneas de investigación afines y

c) la implantación de programas $\mathrm{I}+\mathrm{D}$ de alcance europeo, estatal y autonómico.

\section{La labor de la Sociedad Española de Geomorfología (SEG)}

El interés generalizado que despertaron los temas periglaciares a partir de la década de los 80, particularmente en España, vino favorecido, igualmente, por la Sociedad Española de Geomorfología (SEG), creada en 1987. Su labor en favor de la geomorfología española ha venido siendo valiosa, al tiempo que reconocida internacionalmente su trayectoria. La evidencia más relevante de estos hechos ha sido la realización, en Zaragoza, en septiembre de 2005, de la Sixth International Conference on Geomorphology. De las actividades de la SEG se destacan dos. La organización de sus reuniones nacionales y la publicación de sus actas (con frecuencia bianual desde 1990) (tabla 1) y la edición de la revista "Cuaternario y Geomorfología" (que edita conjuntamente con AEQUA).

Pero, probablemente, el acontecimiento más relevante durante sus primeros años fue la celebración de la primera reunión monográfica sobre periglaciarismo, que, en colaboración con el Servei de Paisatge de la Universidad de Barcelona y la Universidad de Granada, tuvo lugar en Granada, en 1993, donde se puso al día la situación de los estudios periglaciares en la Península Ibérica, Canarias y Baleares. La reunión, de la que se editó el monográfico pertinente, sin duda, marcó un hito muy significativo pues logró reunir por primera vez a los principales grupos de trabajo que venían ocupándose del tema, tanto españoles como portugueses.

\section{La Internacional Permafrost Association. Elemento catalizador de los estudios recientes sobre periglaciarismo en la Península Ibérica}

Otro de los acontecimientos decisivos que afianzó el progreso del estudio de la morfodinámica periglaciar fue la constitución, en 1994, del Grupo Español de la International Permafrost Association (IPA-España), cuyo cometido específico es el fomento de la investigación relacionada con los procesos fríos, particularmente de naturaleza periglaciar. El colectivo, que desde sus primeros años incluyó a investigadores portugueses, puede considerarse como uno de los más dinámicos y novedosos en el panorama de la geomorfología ibérica. Su perfil disciplinar viene aglutinando a diferentes especialistas instalados en distintas áreas de conocimiento, lo que ha llevado a interpretar el origen, desarrollo y resultados de los procesos fríos desde ópticas pluridisciplinares y complementarias. Esta perspectiva viene a mostrar no sólo la consolidación de la disciplina sino también la madurez y rigor de los planteamientos y resultados. En tal sentido, cobra especial relevancia el hecho de que cada vez más los objetivos de las investigaciones tienden a preocuparse por cuestiones explicativas, experimentales y cronológicas, lo que lleva a la continua revisión de métodos de trabajo y esquemas conceptuales. 
Tabla I - Distribución temática de aportaciones a las reuniones nacionales de la Sociedad Española de Geomorfología.

Quadro I - Temas das comunicações apresentadas nas reuniões nacionais da Sociedade Espanhola de Geomorfologia.

Table I - Main research themes in the national conferences of the Spanish Society of Geomorphology.

\begin{tabular}{|c|c|c|c|c|c|c|c|c|c|c|}
\hline Bloque temático & $\begin{array}{r}\text { Reunión I. }^{\mathbf{a}} \\
1990 \\
\end{array}$ & $\begin{array}{r}\text { II. }^{\mathbf{a}} \\
1992 \\
\end{array}$ & $\begin{array}{r}\text { III. }^{\mathbf{a}} \\
1994 \\
\end{array}$ & $\begin{array}{r}\text { IV. }^{\mathbf{a}} \\
1996 \\
\end{array}$ & $\begin{array}{r}V^{\mathbf{a}^{\mathbf{a}}} \\
1998 \\
\end{array}$ & $\begin{array}{r}V^{\mathbf{I I}^{\mathbf{a}}}{ }^{\mathbf{2}} \\
2000\end{array}$ & \multicolumn{2}{|c|}{$\begin{array}{l}\text { VII. }^{\mathbf{a}}{ }^{\text {VIII. }}{ }^{\mathbf{a}} \\
20022004\end{array}$} & Total & $\%$ \\
\hline Morfolodia regional & 3 & - & 3 & - & - & 3 & - & 2 & 11 & 2,1 \\
\hline $\begin{array}{l}\text { Morfología estructural } \\
\text { y neotectónica }\end{array}$ & 6 & 2 & 9 & 4 & 3 & - & - & 3 & 27 & 4,9 \\
\hline Morfología cárstica & 7 & - & 5 & - & 3 & 1 & - & - & 16 & 2,9 \\
\hline Morfología volcánica & - & - & - & - & - & - & 3 & 2 & 5 & 0,9 \\
\hline \multicolumn{11}{|l|}{ Morfología de países frios } \\
\hline Glaciar & 6 & 4 & 4 & 2 & 5 & 4 & 6 & 1 & 32 & 5,9 \\
\hline Periglaciar/crionival & 1 & 1 & 3 & 2 & 1 & 3 & 5 & 2 & 18 & 3,4 \\
\hline Morfología de zonas áridas & 8 & - & 3 & - & - & - & - & - & 11 & 2,1 \\
\hline Morfología litoral & 7 & 5 & 8 & 2 & 7 & 10 & 9 & 7 & 55 & 10,2 \\
\hline Morfología fluvial & 12 & 9 & 9 & 6 & 16 & 15 & 5 & 4 & 76 & 14,2 \\
\hline Morfogénesis de laderas & 4 & 6 & - & 10 & 3 & 4 & - & - & 27 & 4,9 \\
\hline Litología y modelado & - & 8 & - & - & 5 & 5 & 1 & 4 & 18 & 3,4 \\
\hline Erosión de suelos & 12 & 19 & 22 & 13 & 8 & 5 & 6 & 1 & 86 & 15,9 \\
\hline Geomorfología y suelos & 5 & 6 & 6 & - & - & 11 & 4 & - & 32 & 5,9 \\
\hline Paleoambientes cuaternarios & - & - & - & 6 & 7 & 5 & 2 & 3 & 23 & 4,3 \\
\hline Análisis espacial, cartografía, SIG & - & 5 & 1 & 4 & 2 & - & 3 & 1 & 16 & 2,9 \\
\hline Geomorfología y riesgos naturales & - & - & - & - & 8 & 3 & 4 & $48^{*}$ & 63 & 11,8 \\
\hline Otros temas & 3 & 1 & 3 & - & 1 & 1 & 5 & 9 & 23 & 4,3 \\
\hline Total & 74 & 66 & 76 & 49 & 72 & 66 & 52 & 87 & 542 & 100,0 \\
\hline
\end{tabular}

* La VIII. ${ }^{a}$ Reunión (2004) incluyó, además, el tema monográfco Riesgos Naturales y Antrópicos en Geomorfología con una aportación de 48 trabajos de los que 5 hacían referencia a medios fríos (alta montaña)

De tal manera ha sido importante la labor de IPA-España en el ámbito de la Península Ibérica que, en 2005, Portugal, siguiendo el ejemplo español, se ha integrado como miembro asociado en la Internacional Permafrost Association bajo la denominación IPA-Portugal. La colaboración entre las dos comunidades ibéricas culminará en 2007 con la celebración conjunta de sus reuniones nacionales. Ésta tendrá lugar en la serra da Estrela y estará organizada por el grupo de la Universidade de Lisboa.

\section{ANÁLISIS DE LA PRODUCCIÓN CIENTÍFICA MÁS RECIENTE. LAS REUNIONES DE IPA-ESPAÑA.}

El mejor documento para evaluar las publicaciones más recientes sobre morfogénesis periglaciar son las ediciones de las diferentes actas de las reuniones de IPA-España (donde se incluye la aportación portuguesa), que se sintetizan en la tabla 2. Su análisis permite abordar las áreas de estudio, temas preferentes, métodos de trabajo y resultados más significativos y grupos de trabajo más persistentes. 
La investigación en geomorfologia periglaciar en España y Portugal

Tabla II - Trabajos presentados en las diferentes reuniones de IPA-España

Quadro II - Trabalhos apresentados nas várias reuniões do grupo IPA-Espanha

Table II - Research presented in the conferences of the group IPA-Spain

\begin{tabular}{lcccccc}
\hline Reunión(año) & Conferencias & $\begin{array}{c}\text { Trabajos } \\
\text { de campo }\end{array}$ & Comunicaciones & $\begin{array}{c}\text { Ambito } \\
\text { España }\end{array}$ & $\begin{array}{c}\text { Ambito } \\
\text { Portugal }\end{array}$ & $\begin{array}{c}\text { Otros } \\
\text { ámbitos }\end{array}$ \\
\hline I. $^{\text {a }}$ (1994) & 2 & 1 & - & - & - & - \\
II. $^{\text {a }}(1995)$ & - & 2 & - & - & - & - \\
III. $^{\text {a }}(1997)$ & 2 & 2 & 17 & 11 & 1 & 5 \\
IV. $^{\text {a }}(1999)$ & 1 & 1 & 15 & 14 & 1 & - \\
V. $^{\text {a }}{ }^{\text {(2001) }}$ & 1 & 1 & 14 & 9 & 1 & 4 \\
VI. $^{\text {a }}(2003)$ & 2 & 1 & 16 & 9 & 2 & 5 \\
Total & 8 & 8 & 62 & 43 & 5 & 14 \\
\hline
\end{tabular}

\section{1. Áreas de estudio}

Las áreas estudiadas en los 62 trabajos se distribuyen de la siguiente manera: 43 se refieren a España, 5 a Andorra, 5 a Portugal, 1 a las Islas Shetland del Sur (Antártida), 1 a Tarfala (Suecia), 1 al volcán Popocatepétl (México) y 1 a la Península de Varanger (Noruega). Respecto a los que se ocupan de la Península Ibérica (53), la casi totalidad, se centran en espacios de montaña destacando el Pirineo Central (13), Sistema Central (8), sierras de la Estrella (5) y Gredos-Peñalara (3), Béticas (6), Sierra Nevada (5) y Sierra de los Filabres (1), Cordillera Cantábrica (4), Macizos gallegos (3), Sistema Ibérico (2) y Montes de Toledo (1). El resto de trabajos, 3, coinciden en ámbitos extramontañosos: depresión de Vera y rebordes montanos (1), Submeseta sur en su contacto con el ramal meridional de la Cordillera Ibérica (1) y Submeseta sur en su enlace con Sierra Morena (1).

Acerca de las áreas preferentes destacan el Pirineo Central y Sierra Nevada, las montañas más elevadas de la Península Ibérica y en las que es notoria la actual presencia de pisos morfogénicos fríos diferenciados. Por lo que se refiere a las áreas desatendidas hay que incluir a los sistemas montañosos del levante mediterráneo y, en concreto, a los del País Valenciano y extremos más septentrionales de las Béticas, en territorio de Alicante y de Murcia, donde hace ya tiempo se describieron modelados periglaciares pleistocenos, particularmente en lo relativo al tapizado de laderas (Rosselló, 1970; López Bermúdez, 1973; Calvo Cases, 1987) y recientemente confirmados por Marco Molina (2001). Lo mismo podría decirse, aunque en menor medida, del Sistema Costero Catalán, a pesar, también, de la noticia referida al Montseny, donde se identificaron nichos glacionivales y espesos mantos de derrubios ordenados regularizando vertientes (Llobet, 1975/76). Fuera de estos ámbitos también se hecha en falta una particular atención a la Submeseta norte, en concreto al valle del Duero, donde García Fernández (comunicación personal, 1979) ya mostrara depósitos afectados por gelifluxión, y a todo el conjunto del País Vasco y Pirineo Occidental, con morfologías periglaciares heredadas (Ugarte et al., 1984). Con respecto a Portugal se detecta un interés continuado por los modelados de origen frío, en particular en serra da Estrela, por lo que se refiere a dinamica actual y herencia (Vieira, 1998, 2004; Vieira et al. 2003). En las restantes montañas la atención se ha centrado en depósitos de ladera y, en algunos casos, en dinámica actual. Son los casos de las sierras del Minho (Peneda y Geres - Coudé-Gaussen, 1979, 1981; Ferreira et al., 1992, 1999; Vieira, 1995; Marão - Pedrosa, 
1993; Caramulo - Cordeiro, 1993, 2004; Lousã - Daveau, 1973; Lourenço, 1996) o de las sierras del entorno del Macizo Calcário Estremenho (Cunha, 1990; Rodrigues, 1988, 1998). En semejantes términos también habría que contemplar a las islas Baleares, Canarias y Madeira en las que, igualmente, se describieron modelados de procesos fríos (Rosselló, 1977; Höllermann, 1978; Ferreira, 1981; etc.), incluso actuales (Morales et al., 1977; Ferreira, 1981).

\section{Temas preferentes}

Por lo que respecta a la temática dominante existe una gran diversidad de intereses que podrían agruparse en dos tendencias: estudio de formas heredadas y estudio de formas actuales. Una y otra tendencia, a su vez, tiende a afrontarse desde una perspectiva general y desde otra particular. La primera, por ejemplo, supone descripciones cualitativas de formas de modelado y su distribución clasificada en altura, lo que permite ensayar una zonación de pisos morfodinámicos. Esto es lo que ocurre cuando de un sector bien delimitado se obtiene una síntesis producto de anteriores trabajos parciales, como ha venido sucediendo para determinadas unidades del Pirineo Central, conjunto de Galicia, Sierra Nevada, Islas Shetland del Sur y Norte de Portugal.

Otros trabajos son de carácter más específico y se basan en el análisis de formas de modelado a partir del estudio de los procesos desencadenantes heredados o actuales. En tal sentido y sobre morfologías heredadas destacan glaciares rocosos (montes de León - Sierra de Gistredo), campos de bloques (montañas de Galicia - Xistral, Ancares, Courel, Trevinca, etc.) y, particularmente, derrubios de ladera (tipo estratificado y/o asistido), que son los depósitos más extendidos en nuestras montañas. Este último tema ha ocupado atención preferente en el Pirineo Central (eje axial y Prepirineo) y Cordillera Ibérica, ramal castellano donde se han determinado diferentes generaciones, algunas datadas a partir de ${ }^{14} \mathrm{C}$, radiometría y artefactos prehistóricos. Igualmente han ocupado interés destacado en Sierra de Filabres, en el tránsito Meseta Sur y Sierra Morena oriental y en los llanos de Vera-Sorbas (Almería), donde los coluvios periglaciares podrían haber quedado establecidos por encima de los 700-1 000m.

En cuanto a procesos fríos actuales y formas desencadenantes las aportaciones resultan numerosas, aunque focalizadas en tramos de montañas donde las condiciones climáticas son propicias. Así ocurre, por ejemplo, con el comportamiento térmico del aire (Andorra), o con aquellos otros trabajos referidos al estudio de la evolución térmica de la capa activa, a partir de la monitorización de puntos significativos (Pirineo Oriental - macizo de Calmquerdós -, Sierra Nevada, Base Antártica Española, Centro de Portugal - serra da Estrela, etc.), lo que ha implicado el diseño particular de protocolos de actuación in situ. También el régimen de temperaturas ocupa lugar relevante en la clasificación y distribución altitudinal de la morfodinámica, como sucede en la propuesta hecha para Picos de Europa.

En otras ocasiones los trabajos se interesan por el origen y génesis de determinadas microformas a partir del seguimiento monitorizado de procesos (crioturbación, gelisolifluxión, crio-reptación), como ocurre con las figuras geométricas y el desplazamiento de coladas de piedras en Sierra Nevada. En semejante línea de actuación, aunque desde perspectivas más integradoras, destacan las experiencias que se vienen asumiendo acerca del cometido de la nieve en la morfodinámica de Dos Hermanas-Peñalara y en el circo de Gredos (Sistema Central). Igualmente la monitorización ocupa atención particular en el control del movimiento de glaciares rocosos. Los resultados que 
se vienen acumulando en Las Argüalas (Valle del Tena, Pirineo aragonés) y en el Corral del Veleta (Sierra Nevada) están demostrando la bondad de la fotogrametría digital y del GPS como herramientas valiosas. También la fotogrametría está siendo utilizada para la prevención de lahares en el volcán de Popocatepétl (México), a partir del retroceso de la masa glaciar del referido volcán. El seguimiento de la superficie de los glaciares pirenaicos es otra de las preocupaciones que viene atendiéndose desde 1985, al amparo del Programa ERHIN. Los resultados hasta finales del siglo XX, comparados con los que se ofrecieron para 1980 (Serrat, 1981) muestran merma continuada de masa helada. Relacionado con esta temática hay que resaltar, también, los trabajos dedicados a la localización de permafrost alpino en el macizo de Posets (Pirineo Central), donde se ha detectado por encima de los $2700 \mathrm{~m}$. Igualmente se ha localizado en Picos de Europa, en Jou Negro. Y recientemente, también, en el Corral del Veleta (Sierra Nevada), a $3150 \mathrm{~m}$ de altura. En este caso, además, se estudia su relación con las formas asociadas, como igualmente se hace en las Islas de Shetland del Sur.

En otro orden de cosas y referido a acontecimientos históricos de áreas glaciadas debe subrayarse la reconstrucción ambiental a partir del siglo XV, en concreto de la Pequeña Edad del Hielo. En tal sentido sobresalen los estudios que se llevan a cabo en el sur de Andorra, en el valle del Madriu, donde se han detectado diferentes pulsaciones climáticas frías (entre los siglos XV y XIX) a partir del estudio liquenométrico en morrenas de nevero. Y por lo que respecta a los tiempos más recientes, siglos XIX y $\mathrm{XX}$, las reconstrucciones del Corral del Veleta y Maladeta, aunque ahora tomando como referencia documentos de época.

Hay que resaltar en esta relación de temas de estudio la escasez de trabajos referidos a aludes de nieve, pues sólo en una ocasión esta cuestión se trata (valle de Ordesa). Igual podría decirse acerca de la dinámica del paisaje supraforestal o de sus ecosistemas, particularmente contemplando al hombre como agente geomórfico directo o inductor. Sobre estas cuestiones sólo dos trabajos se han contabilizado. Uno, referido al deterioro de formas periglaciares como respuesta a la apertura de pistas de esquí en la estación de Valgrande-Pajares. Otro, preocupado por la incidencia del ganado trashumante en la evolución de formas de modelado de ladera en el macizo de Casamanya (Andorra), particularmente desde que la cabaña ganadera ha tendido a reducirse.

\section{Métodos y técnicas}

Acerca de métodos y técnicas de trabajo empleados igualmente debe destacarse que resultan variados. Sin lugar a dudas el análisis in situ que proporciona el trabajo sistemático de campo continúa acaparando la mayor atención. Es él, junto a la cartografía geomorfológica de detalle $(1 / 5000,1 / 10000,1 / 25000)$ elaborada en una primera fase a partir de fotointerpretación, quien sustenta los trabajos de reconocimiento de formas de modelado.

El conocimiento del comportamiento climático en nuestras montañas se desconoce con cierta precisión por lo que supone un grave inconveniente a la hora de establecer pisos o secuencias morfogénicas altitudinales. Esta situación tiende a mitigarse a partir del tratamiento estadístico y la proyección en altura de los datos de estaciones del llano o enclavadas a media ladera. Los resultados, siempre que estén avalados convenientemente por conjuntos de formas de modelado resultantes y, en su caso, por el tipo de colonización vegetal, permiten tener una aproximación cualitativa del reparto y escalonamiento de procesos fríos en el conjunto de la montaña. La instalación reciente 
de estaciones automáticas completas y sensores autónomos y automatizados de larga duración en parcelas experimentales ha supuesto un gran avance, sobre todo, en el conocimiento del ritmo térmico en superficie y en la capa activa del suelo, a diferentes profundidades. Las experiencias iniciadas en la Antártida, en 1995, y proseguidas y mejoradas en varios enclaves de las montañas de la Península Ibérica (Pirineo, Sierra Nevada, Gredos, Estrela) están resultando de gran interés, pues los resultados que vienen acumulándose permiten explicar mejor el comportamiento mecánico de los suelos y, en particular, lo relativo a procesos y formas instalados en la capa activa.

La morfometría y la sedimentología continúan siendo técnicas muy empleadas en el análisis de los derrubios de ladera (groize, grèze), en las coladas de bloques y en los debris flows, particularmente para determinar secuencias deposicionales y génesis de los arrastres, tal como se detecta en los trabajos realizados sobre grèzes y groizes litées en el Pirineo Central - núcleo axial y Prepirineo -, Sierra de Albarracín, Cordillera Ibérica-rama castellana, Galicia oriental y Sierra de Filabres. Y por lo que respecta a coladas y debris flows, las experiencias de Tarfala (Suecia) resultan significativas. En la mayoría de los casos y determinadas las condiciones de formación de los depósitos, éstos, además, han sido datados a partir de ${ }^{14} \mathrm{C}, \mathrm{U} / \mathrm{Th}$, artefactos arqueológicos, etc., lo que ha permitido situarlos en el tiempo, la mayoría entre el Pleistoceno medio y Subboreal $y$, en ocasiones y gracias a la Palinología, determinar los paleoambientes en los que se construyeron, como sucede en los casos de Bentué de Ransal y el Alto valle del Cinca (Pirineo Central).

En otras ocasiones determinadas técnicas de datación han permitido acercarnos más a nosotros y determinar etapas frías históricas dentro de la Pequeña Edad del Hielo, por ejemplo. Así ha sucedido con la liquenometría, ya comentada para el caso del sur de Andorra. En este mismo rango cronológico, aunque desde diferente perspectiva, la documentación histórica de época está dando resultados excelentes en la reconstrucción del paisaje altimontano de las montañas glaciadas. En tal sentido, los escritos de viajeros de la Ilustración y posteriores de naturalistas se están convirtiendo, cada vez más, en referencias valiosas, particularmente si relatan montañas en las que pudo haber actuado la Pequeña Edad del Hielo. Al respecto, el bagaje de información obtenido de Sierra Nevada y Pirineo central resulta significativo.

Igualmente se está poniendo de relieve la utilidad que poseen los mapas de cobertura nival en la explicación de los procesos y formas asociadas a la nieve a gran escala espacial. La realización sistemática y periódica de fotografías de cobertura nival y su conversión digitalizada a mapas, convierte a éstos en herramientas muy eficaces a la hora de interpretar el reparto espacial de determinados procesos morfogénicos y modelados asociados. Las experiencias que se llevan a término en Dos Hermanas-Peñalara (Sistema Central), inmersas en una filosofía geográfica integradora resultan novedosas y de gran interés. En similar línea habría también que citar los ensayos acerca de las relaciones entre especies vegetales y pedreras de alta montaña (Sierra de Gredos), aspecto geomorfobiológico que ya fue ensayado en Pirineo oriental (Soutadé, 1978; Serve, 1989), desde la perspectiva geomorfológico y geobotánica, respectivamente.

Las técnicas geofísicas igualmente han estado presentes en determinados trabajos, en particular en aquéllos dedicados a la detección de permafrost profundo y a su estado físico, pues su empleo ha permitido localizar el reparto extensivo y potencia de estas masas heladas en diferentes enclaves montañosos. Las más fecundas experiencias se han centrado en Posets (Pirineo Central), donde en relación a la altitud del macizo se ha distinguido permafrost esporádico, discontínuo y contínuo. Experiencias recien- 
tes también se han llevado a cabo en Sierra Nevada. En ambos casos los resultados obtenidos han sido fruto de diferentes protocolos de actuación (refracción sísmica, SEV, geo-radar, etc.), completados con mediciones de BTS.

El control de la movilidad de los glaciares rocosos, a partir de puntos fijos instalados en diferentes lugares de su superficie, ha supuesto el empleo de técnicas topográficas, geodésicas y fotogramétricas. Los resultados obtenidos, de gran interés, validan la fiabilidad de ellas. En tal sentido, sobresalen los trabajos llevados a cabo en Las Argüalas (Pirineo Central), desde 1991 hasta 2000. También los iniciados en el Corral del Veleta (Sierra Nevada) en el verano del 2000. La bondad de estas técnicas abre expectativas en el control de la inestabilidad de determinadas laderas, en particular las afectadas por flujos y deslizamientos gelifluidales y/o soligelifluidales.

\section{Perfil y procedencia de los autores}

Acerca del perfil y procedencia de los autores, siempre instalados en universidades o centros de investigación, hay que reseñar que la casi totalidad son geomorfólogos cuaternaristas y dentro de ellos predominan los geógrafos, seguidos de geólogos. También es relevante la presencia de físicos y edafólogos y, recientemente, la de cartógrafos y geodestas. Y en cuanto a la organización de su labor reseñar la predominancia del trabajo en equipo, caracterizado, éste, por la pluridisciplinariedad.

En cuanto a la autoría de los trabajos resalta el escaso número de aportaciones firmadas por un solo autor. De los 62 registros que venimos comentando esto sólo se cumple en siete ocasiones (2, en 1997; 1, en 1999; 1, en 2001; 3, en 2003), pues el resto corresponde a grupos, lo que viene a mostrar que la producción científica se afronta desde equipos de trabajo movidos por intereses científicos comunes y que, por lo general, centran atención preferente en determinados ámbitos geográficos y temáticas (tabla 3 y figura 1). También señalar de estos 62 trabajos que en 50 ocasiones todos los firmantes son españoles. La participación extranjera se cumple en 12 casos (Portugal, Francia, Reino Unido, USA, Noruega, México) y de ellos, en 4 títulos, resulta total. En cuanto a la procedencia de las firmas españolas existe una predominancia de Departamentos Universitarios (Geografía, Geología, Física, Edafología, Ingeniería del Terreno, Ingeniería Geológica, Medio Ambiente, Fotogrametría, etc.), seguida de unidades de investigación del CSIC y de diferentes organismos de la Administración pública. Muy puntualmente aparecen empresas privadas.

\section{CONCLUSIONES. HACIA NUEVAS PERSPECTIVAS}

El interés por los temas periglaciares entre los geomorfólogos y geógrafos físicos españoles y portugueses durante estas últimas décadas ha sido notable y se ha venido constatando en la producción científica publicada y en la calidad de las aportaciones, en las que se detecta una constante renovación de ideas y métodos de trabajo, como se ha reflejado recientemente en el número 30 (2004) de la revista Cuadernos de Investigación Geográfica, monográfico dedicado a procesos geomorfológicos en medios fríos. También habría que subrayar en este devenir reciente que la labor española y portuguesa ha empezado a valorarse positivamente entre la comunidad internacional, sobre todo europea, y muy en especial a partir del proyecto PACE (Permafrost and Climate in Europe) y más recientemente a raíz de la creación de la red European Science Foundation-PACE 
21, en los que España y Portugal han venido participando. Como también lo ha venido haciendo hecho en la I. ${ }^{a}$ Conferencia Europea del Permafrost (Roma, 2001), la VIII. ${ }^{a}$ Conferencia Internacional del Permafrost (Zurique, 2003) y la II. ${ }^{a}$ Conferencia Europea del Permafrost (Potsdam, 2005).

En su conjunto, los resultados científicos acumulados a lo largo de esta última década han venido a demostrar la existencia de una dinámica geomórfica fría generalizada con repercusión en las formas de modelado en el conjunto de la Península Ibérica, aunque con mayor intensidad en las montañas, lo que atestigua que el paisaje reciente de ellas, el morfológico, particularmente, está muy asociado a sistemas de procesos de erosión vinculados a la acción combinada del hielo, frío y nieve a lo largo del Pleistoceno. Y por lo que respecta al actual dominio de estos sistemas de procesos se ha demos-

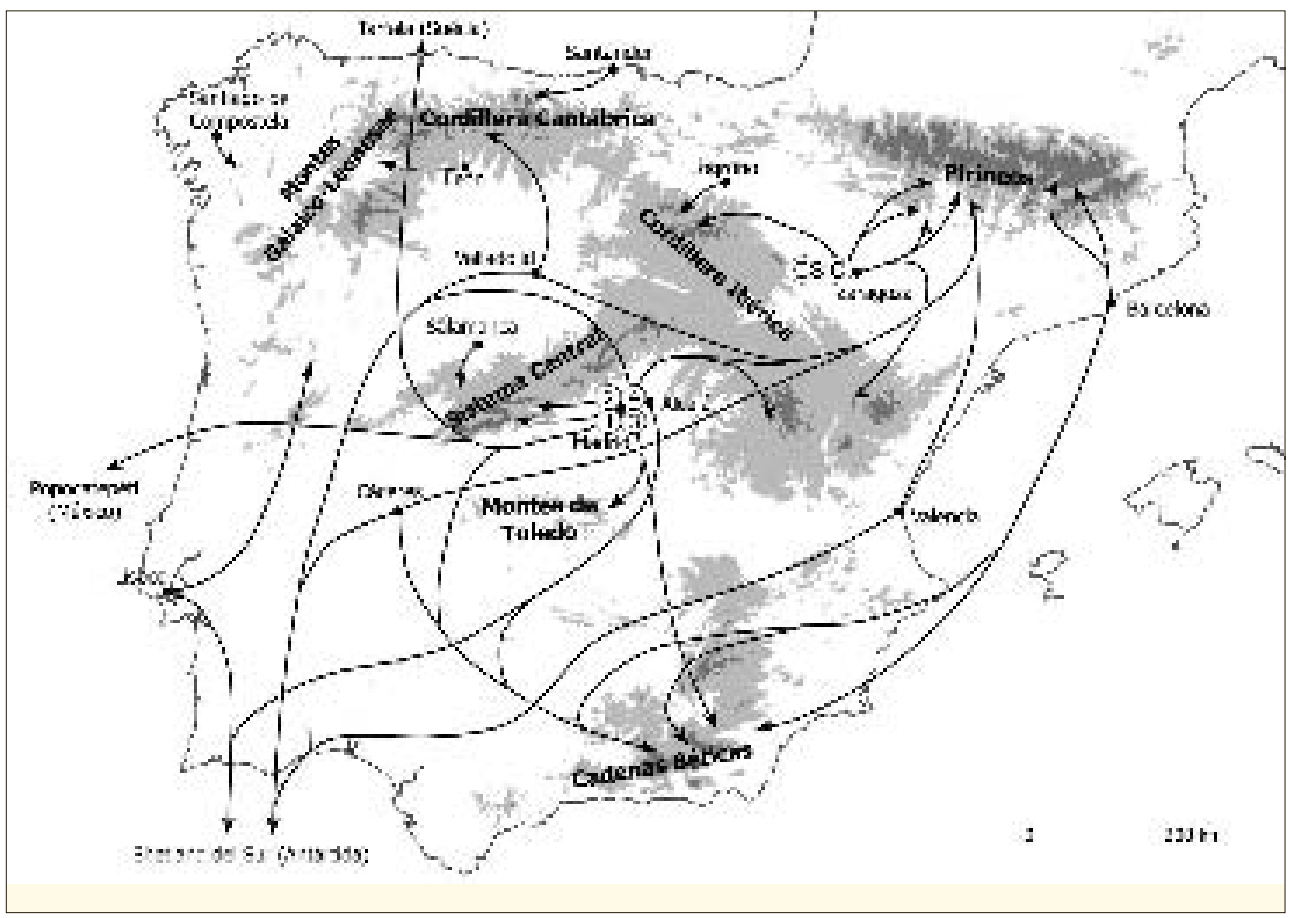

Fig. 1. Grupos de investigación y áreas preferentes de estudio.

1-3 - Grupos de la Universidad Complutense de Madrid, 4 - Grupo de la Universidad Autónoma de Madrid (detalles en la tabla 3)

Fig. 1 - Grupos de trabalho e principais regiões de estudo.

1-3 - Grupos da Universidade Complutense de Madrid,

4 - Grupo da Universidade Autónoma de Madrid (ver pormenores no quadro 3)

Fig. 1 - Working groups and main research regions.

1-3 - Groups of the Complutense University of Madrid,

4 - Group of the Autonomous University of Madrid

(see details in table 3) 
Tabla III - Grupos de trabajo consolidados, áreas geográficas y tendencias temáticas preferentes

Quadro III - Grupos de trabalho, regiões e temáticas de investigação

Table III - Working groups, regions and themes of research

\begin{tabular}{|c|c|c|}
\hline Grupo de trabajo & Área geográfica preferente & $\begin{array}{l}\text { Predominancia de temas } \\
\text { tratados }\end{array}$ \\
\hline Grupo de Zaragoza & $\begin{array}{l}\text { Pirineo Central, Prepirineo } \\
\text { Central, Sistema Ibérico } \\
\text { (ramal sur). }\end{array}$ & $\begin{array}{l}\text { Derrubios estratificados. } \\
\text { Catalogación de procesos } \\
\text { y formas. Cronología. }\end{array}$ \\
\hline Grupo del CSIC (Jaca-Zaragoza) & $\begin{array}{l}\text { Pirineo Central, Prepirineo } \\
\text { Central, Sistema Central } \\
\text { (ramal norte). }\end{array}$ & $\begin{array}{l}\text { Derrubios estratificados. } \\
\text { Zonación de procesos y formas. } \\
\text { Cronología. }\end{array}$ \\
\hline Grupo de Madrid (Complutense 1) & $\begin{array}{l}\text { Sistema Central, Tarfala } \\
\text { (Suecia). Popocatepétl } \\
\text { (México). }\end{array}$ & $\begin{array}{l}\text { Morfodinámica nival. Debris flows. } \\
\text { Prevención de lahares. }\end{array}$ \\
\hline Grupo de Madrid (Complutense 2) & Sistema Central. & Catalogación de formas. Cronología. \\
\hline Grupo de Madrid (Complutense 3) & $\begin{array}{l}\text { Sierra de los Filabres, } \\
\text { Montes de Toledo-Meseta sur. }\end{array}$ & Derrubios de ladera. \\
\hline Grupo de Madrid (Autónoma) & $\begin{array}{l}\text { Cordillera Ibérica ramal } \\
\text { castellano. }\end{array}$ & Derrubios de ladera. Cronología. \\
\hline Grupo de Santiago de Compostela & Macizos gallegos. & $\begin{array}{l}\text { Catalogación de formas } \\
\text { y zonación altitudinal. Cronología. }\end{array}$ \\
\hline Grupo de Barcelona & $\begin{array}{l}\text { Sierra Nevada, Pirineo } \\
\text { Oriental, Andorra, SE. } \\
\text { Península Ibérica. }\end{array}$ & $\begin{array}{l}\text { Monitorización de procesos. } \\
\text { Zonación altitudinal. Glaciarismo } \\
\text { histórico. Evolución de los } \\
\text { estudios periglaciares. }\end{array}$ \\
\hline Grupo de Valladolid & $\begin{array}{l}\text { Pirineo Central, } \\
\text { Cordillera Cantábrica. }\end{array}$ & $\begin{array}{l}\text { Catalogación de formas. } \\
\text { Zonación altitudinal. } \\
\text { Glaciarismo histórico. }\end{array}$ \\
\hline Grupo de Alcalá de Henares-Lisboa & Shetland del Sur (Antártida). & Termicidad capa activa. \\
\hline Grupo de Cantabria & Picos de Europa. & Termometría y modelados. \\
\hline Grupo de León & Montes de León. & Glaciares rocosos heredados. \\
\hline Grupo de Lisboa & $\begin{array}{l}\text { Estrela, Gerês, Macizo } \\
\text { Calcário Estermenho, } \\
\text { Shetland del Sur (Antártida). }\end{array}$ & $\begin{array}{l}\text { Catalogación de formas. } \\
\text { Termicidad del suelo. } \\
\text { Detección remota. }\end{array}$ \\
\hline Grupo de Lisboa-Coimbra & Portugal. & $\begin{array}{l}\text { Historia del periglaciarismo } \\
\text { en Portugal. }\end{array}$ \\
\hline $\begin{array}{l}\text { Grupo de Barcelona-Madrid } \\
\text { (Complutense I) } \\
\text {-Alcalá de Henares-Cáceres }\end{array}$ & Sierra Nevada. & $\begin{array}{l}\text { Permafrost y formas asociadas. } \\
\text { Control glaciar rocoso. } \\
\text { Termicidad del suelo. } \\
\text { Morfodinámica nival. }\end{array}$ \\
\hline $\begin{array}{l}\text { Grupo de Valladolid-Madrid } \\
\text { Autónoma-Cáceres-Valencia }\end{array}$ & $\begin{array}{l}\text { Pirineo Central, } \\
\text { Shetland del Sur (Antártida). }\end{array}$ & $\begin{array}{l}\text { Permafrost. Catalogación de formas. } \\
\text { Control glaciares rocosos. Aludes. }\end{array}$ \\
\hline
\end{tabular}


trado su eficacia en los niveles supraforestales (superada el timberline), muy visibles en el Pirineo y Sierra Nevada, que son los sistemas montañosos con niveles de cumbres que superan los $3000 \mathrm{~m}$.

El camino recorrido ha sido importante como así también los logros. Ahora, y a la vista de lo conseguido, lo que cabe es reflexionar y preguntarse hacia donde deben encaminarse las investigaciones. En tal sentido, parece oportuno, a la vista de los últimos trabajos aparecidos, señalar el interés que vienen mostrando diferentes programas de actuación. Entre ellos destacan:

A. Estudio de la génesis y determinación cronológica de formas de modelado heredadas y subactuales.

De entre los temas preferentes por su significado paleoclimático destacan los derrubios de ladera (tipo grèze litée y groize) y los glaciares rocosos. Sobre los primeros interesa resaltar que son testigos morfológicos muy fiables en la determinación de los límites inferiores de los procesos fríos, adquierendo mayor significado cuando sus lechos pueden ser datados $\left({ }^{14} \mathrm{C}\right.$, U/Th, artefactos prehistóricos, fósiles, etc.), como viene ocurriendo en las Cordilleras Béticas, Sistema Ibérico y Prepirineo central. Y por lo que respecta a glaciares rocosos destacar, igualmente, que su progresivo descubrimiento en montañas débilmente glaciadas, ramal castellano de la Cordillera Cantábrica - por ejemplo, viene a ratificar la amplitud espacial de regímenes periglaciares en la Península Ibérica durante el Pleistoceno-holoceno.

B. Reconstrucción ambiental holocena del paisaje de la alta montaña.

Se trata de una perspectiva geográfica que tiende a explicar la evolución del paisaje en los medios fríos de las montañas desde interpretaciones globales. En ello, no solamente los modelados de relieve poseen un significado particular, por su configuración topográfica y fijación espacial-altitudinal, sino también todos aquellos otros datos asociados a la génesis del depósito, como los análisis morfométricos, sedimentológicos y morfoedáficos. También resulta de gran interés la información de carácter paleobiogeográfico, particularmente cuando se toman como referencia y analizan polínicamente con datación absoluta perfiles de turberas y lóbulos de gelifluxión vegetalizados. La combinación de resultados y su interpretación global está llamada a ser una sólida aportación en la reconstrucción ambiental holocena del paisaje de la alta montaña.

\section{Estudio de la deglaciación histórica de la Pequeña Edad del Hielo.}

Entre el periodo de los siglos XV-XIX, en la denominada Pequeña Edad del Hielo, el incremento de los glaciares alpinos tuvo su reflejo en determinadas montañas de la Península Ibérica. El estudio de la deglaciación y de sus etapas de estos enclaves es uno de los temas a los que se vienen dedicando esfuerzos, sobre todo en Pirineo central y oriental, Sierra Nevada y Picos de Europa. Y viene haciéndose desde diferentes perspectivas:

a) Análisis de formas de modelado;

b) Documentación histórica (a partir del siglo XVIII, sobre todo) y

c) Análisis liquenométricos de depósitos.

D. Monitorización de procesos morfogénicos fríos actuales. Dinámica del paisaje.

Este bloque temático incide en el estudio de los procesos fríos actuales y su relación con la dinámica del paisaje. En la actualidad los esfuerzos se centran en el control 
de la estabilidad de la fracción mineral a partir del seguimiento térmico del permafrost alpino y de su estado físico y del manto nival y formas de modelado asociadas. Los enclaves montañosos donde ya se trabaja en tal sentido se sitúan en Gredos, Estrela, MaladetaPosets, Sierra Nevada. Asimismo se están sentando las bases para la creación de una red de seguimiento climático en medios supraforestales de las montañas de la Península Ibérica. Su finalidad es determinar las relaciones que existen entre manto nival - temperatura de la capa activa, estabilidad del suelo y sus posibles conexiones con el denominado cambio global.

\section{E. Riesgos naturales y cartografía de riesgos.}

Es la vertiente aplicada más cultivada en los estudios de medios fríos en la Península Ibérica. Trabajos recientes han sido llevados a término en el Pirineo oriental y Principado de Andorra. Éstos vienen focalizando atención en la detección de inestabilidad de laderas, particularmente, en los casos de derrumbes de rocas y deslizamientos. También existen experiencias en la determinación de aludes de nieve (Furdada, 1996). Tanto en un caso como en otro los objetivos tienden a analizar parámetros desencadenantes y ambientes favorables al desarrollo de tales eventos y, a partir de ellos, determinar probabilidades de acontecimientos y grado de peligrosidad. En este último sentido, la elaboración de mapas de susceptibilidad de riesgos ocupa lugar destacado.

\section{F. Suministro de datos base para la planificación de usos del suelo}

Esta línea de actuación resulta igualmente geográfica, pues lo que se pretende ahora es analizar y diagnosticar el estado real y potencialidad de los sistemas naturales de nuestras montañas con la finalidad de suministrar datos significativos para su mejor gestión. En el caso de los niveles supraforestales acerca de su inestabilidad ante determinadas actuaciones, por ejemplo, las repercusiones que supone la alteración y reducción de pastizales por la instalación de estaciones de invierno (infraestructuras y pistas de esquí). También y desde perspectivas próximas existen experiencias que tienden a resaltar valores naturales y culturales del paisaje. De entre ellas resalta la catalogación de enclaves singulares de interés geoturístico, como se hizo en la serra da Estrela. O como aquel otro que justificó los valores biofísicos del valle del Madriu (Andorra) para su catalogación como Patrimonio de la Humanidad por la UNESCO.

\section{E. Investigaciones en la Antártida.}

Actualmente los trabajos en temas periglaciares de los investigadores españoles y portugueses en la Antártida se centran en el archipiélago de las Islas Shetland del Sur. Dos cuestiones son las más atendidas: cartografía geomorfológica de los espacios deglaciados y monitorización del estado térmico de la capa activa de estos espacios. El interés de ambos temas resulta evidente. Por un lado, contribuye al conocimiento y distribución espacial de los resultados morfogenéticos fríos de altas latitudes en el modelado. Y por otro, aporta nuevos datos de la evolución de las temperaturas en el suelo, de tanto interés en el debate abierto acerca del denominado cambio climático. Ambos trabajos están encuadrados en sendos proyectos internacionales promovidos por la IPA - International Permafrost Association (TSP, Termal State of Permafrost) y SCAR Standing Scientific Group on Geosciences (ANTPAS, Antarctic and sub-Antarctic Permafrost, Periglacial and Soil Environments), respectivamente. 


\section{REFERENCIAS BIBLIOGRÁFICAS}

Asensio Amor I, González Martín J A (1974) Presencia de materiales detríticos ordenados (grèze litées) en el valle del Tajuña (Caravana-Villarejo de Salvanés). Estudios Geológicos, XXX, 69-73.

Barrère P (1952) Evolution mécanique et nivation sur les versants calcaires de la haute montagne pyrénéenne. Pirineos, 24: 201-213.

Brochu M (1969) Existence d'une zone périglaciaire dans la région sommitale du Pic (o Pico) dans l'île du Pic aux Açores. Zeitschrift fur Geomorphologie, N.F., 13(1): 115-118.

Brosche K U (1978) Formas actuales y límites inferiores periglaciares en la Península Ibérica. Estudios Geográficos, 151: 131-161.

Bullón Mata T (1977) Los fenómenos periglaciares de la Mujer Muerta (Sierra de Guadarrama). $V$ Coloquio de Geografía. AGE-Universidad de Granada, Granada: 35-40.

Calvo Cases A (1987) Geomorfología de laderas en las montañas del País Valenciano. Edicions Alfons El Magnànim, Institució Valenciana d'Estudis i Investigació, València.

Carvalho G S (1964) Areias da Gândara (Portugal). Uma formação eólica quaternária. Publ. Museu Lab. Min. Geol. Fac. Ciências do Porto, 82: 7-32.

Carvalho G S (1955) A Gândara (Portugal) e as Landes da Gasconha (França). Memórias e Notícias, 37: 20-36.

Cordeiro A M R (2004) Dinâmica de vertentes em montanhas ocidentais do Portugal Central. Dissertação de Doutoramento em Letras na Área de Geografia. Universidade de Coimbra.

Cordeiro A M R (1993) Dinâmica de vertentes nos Pleniglaciários e Tardiglaciário wurmianos nas Montanhas Ocidentais do Centro-Norte de Portugal. A importância do gelo de segregação. Actas da II Reunião do Quaternário Ibérico, Madrid: 881-888.

Coudé-Gaussen G (1981) Les Serras da Peneda et do Gerês. Étude géomorphologique. Memórias do Centro de Estudos Geográficos, Lisboa, 5: 254.

Coudé-Gaussen G (1979) Les Serras da Peneda et do Gerês (Minho - Portugal), Formes et formations d'origine froide en milieu granitique. Thèse $3 .{ }^{\text {ème }}$ Cycle. Université Paris I, Paris.

Creus J, García Ruiz J M (1977) Observaciones sobre solifluxión en el alto valle del río Gállego. Trabajos sobre Neógeno-Cuaternario, 6: 57-64.

Cunha L (1990) As serras calcárias de Condeixa-Sicó -Alvaiázere. Geografia Física, Coimbra, 1: 329 .

Daveau S (1978) Le périglaciaire d'altitude au Portugal. Colloque sur le périglaciaire d'altitude du domaine méditerranéen et abords. Strasbourg: 63-78.

Daveau S (1973) Quelques exemples d'évolution quaternaire des versants au Portugal. Finisterra - Revista Portuguesa de Geografia, VIII(15): 5- 45.

Dresch J (1937). De la Sierra Nevada au Grand Atlas, formes glaciaires et de nivation. Mélanges de géographie et d'orientalisme offerts à E.F. Gautiers. Tours: 194-212.

Ferreira A B (1981) Manifestações periglaciárias de altitude na ilha da Madeira. Finisterra - Revista Portuguesa de Geografia, XVI(32): 213-229.

Ferreira A B, Rodrigues M L, Vieira G T (2000) Manifestações herdadas e actuais de climas frios em Portugal. In: Procesos y formas periglaciares en la montaña mediterránea. Instituto de Estudios Turolenses. Teruel: 161-190.

Ferreira A B, Vidal Romani J R, Zêzere J L, Rodrigues M L (1999) A glaciação plistocénica da Serra do Gerês. Vestígios geomorfológicos e sedimentológicos. CEG, AGFA, Lisboa, Rel., 37. 
La investigación en geomorfologia periglaciar en España y Portugal

Ferreira A B, Vidal Romani J R, Vilaplana J M, Rodrigues M L, Zêzere J L, Monge C (1992) Formas e depósitos glaciários e periglaciários da Serra do Gerês-Xurés (Portugal, Galiza). Levantamento cartográfico. Cuadernos Laboratório Xeolóxico de Laxe, 17: 121-135.

Floristán A (1953) El modelado periglaciar. Departamento de Geografía Aplicada del CSIC, Zaragoza.

Furdada G (1996) Estudi de les allaus al Pirineu occidental de Catalunya: predicció espacial i aplicacions de la cartografia. Geoforma-Ediciones, Logroño.

García Rosell L, Pezzi M (1977) Análisis de depósitos periglaciares en el sector central de las Cordilleras Béticas (Andalucía). V Coloquio de Geografía. AGE-Universidad de Granada, Granada: 99-107.

García Ruiz J M (1999) La producción científica de la Geomorfología española y su impacto a través de las publicaciones periódicas. CSIC-SEG, Zaragoza.

García Sainz L (1935) Morfología glaciar y periglaciar de la región de la Noguera (cuenca CincaSegre). Boletín de la Sociedad Geográfica Nacional, 54: 64-110.

Ginés A, Mateu J (1977) Fenómenos de clima frío en el Alt Maestrat. Trabajos del Neógeno Cuaternario, 6: 93-103.

Gómez Ortiz A (1980) Estudio geomorfológico del Pirineo catalán: morfogénesis glacial y periglacial de los altos niveles y vertientes merdionales de los macizos de Calmquerdós, Tossa Plana de Llés y Port Negre (Cerdanya-Alt Urgell). Tesis doctoral, Departamento de Geografía, Universidad de Barcelona, Barcelona.

Gómez Ortiz A, Martí Bono C E, Salvador Franch F (2001) Evolución reciente de los estudios de geomorfología glaciar y periglaciar en España (1980-2000). In Gómez Ortiz A, Pérez González A (ed.) Evolución reciente de la Geomorfología española (1980-2000). SEG y Servei de Paisatge de la UB, Geoforma, Logroño: 139-184.

Gómez Ortiz A, Serrat D (1977) Las formaciones geométricas periglaciares de los altos niveles del Pirineo Oriental. V Coloquio de Geografía. AGE-Universidad de Granada, Granada: 75-81.

Guilcher A (1949) Sur les vallons côtiers suspendus des environs de Lisbonne et leurs analogies avec ceux du littoral breton. C. R. Acad. Sc. Paris, 228 : 1512-1514.

Gutiérrez M, Peña Monné J L (1975) Karst y periglaciarismo en la Sierra de Javalambre (provincia de Teruel). Boletín Geológico y Minero, 86:561-572.

Hamelin L E (1958) Matériaux de géomorphologie périglaciaire dans 1'Espagne du Nord. Revue de Géographie des Pyrénées et du Sud-Ouest, XXV: 241-256.

Hempel L (1960) Límites altitudinales geomorfológicos en Sierra Nevada. Estudios Geográficos, 78: 81-93.

Höllermann P (1978) Soil movements in the subtropical mountain environment of Higt Tenerife (Canary Islands). Colloque sur le périglaciaire d'altitude du domaine mediterranéen et abords. Strasbourg: 91-112.

Höllermann P (1967) Zur Verbreitung rezenter Periglacialer Kleinformen in den Pyrenäen und Ostalpen. Gotinga.

López Bermúdez F (1973) La vega alta del Segura. Clima, hidrología y geomorfología. Departamento de Geografía, Universidad de Murcia, Murcia.

Lourenço L (1996) Serras de Xisto do Centro de Portugal. Contribuição para o conhecimento geomorfológico e geo-ecológico. Dissertação de Doutoramento na área de Geografia Física. Universidade de Coimbra

Llobet S (1975-76) Materiales y depósitos periglaciares en el macizo del Montseny. Revista de Geografia, IX: 35-58. 
Marco Molina J A (2001) Derrubios estratificados en la Sierra de Aitana, Alicante (España). Eria, 51: 79-92.

Martí Bono C, González Martín J A (1979) Nota sobre algunos depósitos coluviales del Alto Aragón. III Reunión Nacional del GETC, Zaragoza: 199-207.

Martínez de Pisón E, Muñoz Jiménez J (1972) Observaciones sobre la morfología del Alto Gredos. Estudios Geográficos, 129: 3-103.

Martins A F (1949) Maciço Calcário Estremenho. Contribuição para um estudo de geografia física. Coimbra.

Messerli B (1965) Beiträge zur Geomorphologie der Sierra Nevada (Andalusien). Juris Verlag. Zurich.

Morales A, Martín F, Quirantes F (1977) Formas periglaciares en Las Cañadas del Teide. Aula de Cultura, Santa Cruz de Tenerife.

Pedraza Gilsanz J (1978) Estudio geomorfológico de la zona de enlace entre las Sierras de Gredos y Guadarrama (Sistema Central Español). Tesis doctoral, Facultad de Geología, Universidad Complutense de Madrid, Madrid.

Pedrosa A S (1993) Serra do Marão. Estudo de Geomorfologia. Dissertação de Doutoramento na área de Geografia Física. Universidade do Porto.

Pellicer Corellano F (1980) El periglaciarismo del Moncayo. Geographicalia, 7-8: 3-25.

Peña Monné J L (1998) Los estudios sobre procesos de clima frío en España: balance y perspectivas. In: Procesos biofísicos actuales en medios frios. Publicacions UB. Barcelona: 43-54.

Peña Monné J L (1980) Estudio geomorfológico de la Conca de Tremp y las sierras prepirenaicas leridanas entre los ríos Segre y Noguera Ribagorzana. Tesis doctoral. Departamento de Geografía, Universidad de Zaragoza, Zaragoza.

Pérez Alberti A (1979) Nuevas observaciones sobre glaciarismo y periglaciarismo en el NO. de la Península Ibérica. La Galicia sudoriental. Acta Geológica Hispánica. Homenatge a L. Solé Sabarís, Barcelona: 441-444.

Pissart A (1999) The UGI Periglacial Comission and its role from 1949 until 1980. Biuletyn Peryglacjalny, 38: 7-12.

Rebelo F (1975) Serras de Valongo. Estudo de Geomorfologia. Biblos, Coimbra, 9: 194.

Rodrigues M L (1998) Evolução geomorfológica quaternária e dinâmica actual. Aplicações ao ordenamento do território. Exemplos no Maciço Calcário Estremenho. Dissertação de Doutoramento em Geografia Física, Lisboa.

Rodrigues M L (1988) As depressões de Minde e de Alvados. Depósitos e evolução quaternária das vertentes. Dissertação de Mestrado em Geografia Física e Regional. Universidade de Lisboa, 208 pp.

Rosselló V (1977) El modelado de las áreas glaciales y periglaciales. Ponencia I. V Coloquio de Geógrafos Españoles. AGE-Universidad de Granada, Granada: 25-28.

Rosselló V (1977) Screes periglaciares en la montaña mallorquina. V Coloquio de Geógrafos Españoles. AGE-Universidad de Granada, Granada: 83-92.

Rosselló V (1970) Clima y morfología pleistocena en el litoral mediterráneo español. Papeles del Departamento de Geografía. Secretariado de Publicaciones, Universidad de Murcia: 79-101.

Sanz Herraiz C (1977) Morfología glaciar en la Sierra de Guadarrama. El modelado de las áreas glaciares y periglaciares (Peñalara-Los Pelados). V Coloquio de Geografía. AGE-Universidad de Granada, Granada: 49-55.

Serrat D (1977) Estudio geomorfológico del Pirineo Oriental (Puigmal, Costabona). Tesis doctoral, Facultad de Geología, Universidad de Barcelona, Barcelona. 
Serrat D (coord.) (1981) Catàleg de les glaceres de la Peninsula Ibérica. Muntanya: 435-440 y 498 -503 .

Serve L (1989) Recherches écologiques sur quelques groupements végétaux de l'étage alpin des Pyrénées Orientales. Thèse, Faculté de Sciences, Université de Perpignan.

Solé Sugrañyes L (1973) Nota sobre el límite inferior de los derrubios estratificados de vertiente (grèze litées) en el sector de Sant Llorenç de Morunys (Pirineo Oriental. Provincia de Lérida). Acta Geológica Hispánica, 8 : 167-173.

Soutadé G (1978) Modelé et dynamique actuelle des versants supraforestiers des Pyrénées Orientales. Thèse, Université de Bordeaux, Bordeaux.

Soutadé G, Baudière A (1970) Végétation et modelés des hauts versants septentrionaux de la Sierra Nevada. Annales de Geographie : 436, 709-736.

Tricart J (1966) Quelques aspects des phénomènes périglaciaires quaternaires dans la Péninsule Ibérique. Biuletyn Peryglacjalny, 15: 313-327.

Tricart J, Cailleux A (1967) Le modelé des régions périglaciares. SEDES, Paris.

Tricart J, Cailleux A (1962) Le modelé glaciaire et nival. SEDES, Paris.

Ugarte F, González Martín J A, Alonso F (1984) Acumulaciones detríticas cuaternarias en el valle del río Oñate (Guipúzcoa). Munibe, 36: 65-91.

Vieira G T (2004) Geomorfología dos planaltos e altos vales da Serra da Estrela. Ambientes frios do Plistocénico Superior e dinâmica actual. Dissertação de Doutoramento em Geografia, área Geografia Fisica. Universidade de Lisboa, Lisboa.

Vieira G T (ed.) (1998) Glacial and periglacial Geomorphology of the Serra da Estrela. Guidebook for the field-trip IGU. Commission on Climate Change and Periglacial Environments. CEG and Department of Geography, University of Lisbon, Lisbon.

Vieira G T (1995) Processos morfogenéticos recentes e actuais na Serra do Gerês. Dissertação de Mestrado em Geografia Física e Ambiente. Faculdade de Letras da Universidade de Lisboa, Lisboa.

Vieira G T, Cordeiro A M R (1998) Geomorfología periglaciária em Portugal. Estado do conhecimiento. In: Procesos biofísicos actuales en medios fríos. Estudios recientes. Publicacions de la Universitat de Barcelona, Barcelona: 347-371.

Vieira G T, Mora C, Ramos M (2003) Ground temperature regimes and geomorphological implications in a Mediterranean mountain (Serra da Estrela. Portugal). Geomorphology, 52, 57-72. 



\section{O RELEVO DE PORTUGAL ${ }^{1}$}

Maria AsSUnÇão ARAúJOº

O livro editado pela Associação Portuguesa de Geomorfólogos foi apresentado publicamente numa sessão de homenagem a Mariano Feio, em Outubro de 2004. Teve uma primeira divulgação no 2. ${ }^{\circ}$ Congresso de Geomorfologia, realizado em Coimbra, em Novembro do mesmo ano. Destina-se a colmatar uma lacuna nos estudos geomorfológicos e pretende constituir um texto de base, tal como o livro Introduction à la Géologie Générale du Portugal, publicado pelos Serviços Geológicos de Portugal, com data de 1979 e ainda não substituído, apesar de sobre ele ter passado já um quarto de século.

O livro desenvolve amplamente uma primeira tentativa, datada de 1987, apresentada por Suzanne Daveau no final do $1 .^{\circ}$ volume da Geografia de Portugal (Edições J. Sá da Costa). Mas enquanto este volume da Geografia de Portugal se baseava sobretudo na análise, feita pela autora, de mapas de diversas origens, no volume em apreço dá-se a palavra a alguns dos investigadores responsáveis pelo estudo das diferentes regiões do país, para fazerem a síntese, o "estado da arte" das áreas que melhor conhecem. A diversidade, baseada na originalidade das contribuições pessoais, longe de constituir um problema, representa sem dúvida uma das riquezas do livro, que Suzanne Daveau quis manter, apesar da necessidade de um mínimo de uniformização. Como seria de esperar, essa diversidade torna muito difícil uma análise conjunta. Por isso, tentaremos uma abordagem aos diferentes capítulos, esforçando-nos por mostrar aquilo que, a nosso ver, é a contribuição mais relevante, quer pela originalidade/novidade, quer pela possibilidade de constituir uma peça chave na elaboração de correlações e sínteses mais ou menos abrangentes.

Nesta obra, Suzanne Daveau deu sequência ao trabalho desenvolvido por Mariano Feio; por isso, o livro corresponde também, de certo modo, a uma homenagem ao papel fundamental que os estudos de Mariano Feio, entretanto falecido, tiveram neste domínio científico. Na Introdução, Suzanne Daveau faz uma breve resenha das motivações para a produção do livro, salientando a necessidade de que a divulgação dos estudos

1 Feio M e Daveau S (2004) O relevo de Portugal. Associação Portuguesa de Geomorfólogos, Coimbra, 151 pp.

2 Professora Associada do Departamento de Geografia da Faculdade de Letras da Universidade do Porto. Via Panorâmica s/n. 4150-564 Porto, Portugal. Tel. +351226 077 100. Fax +351 226091 610. E-mail: asaraujo@letras.up.pt 
geomorfológicos se faça numa linguagem o menos hermética possível, de molde a motivar os cidadãos em geral, e também aqueles que estão em postos de decisão, para a necessidade de compreender o território no qual se quer intervir, para que essas intervenções respeitem os equilíbrios e o património geomorfológico. A divulgação científica dos aspectos geomorfológicos deverá ser também orientada para os cultores de outras ciências, para os quais os avanços conseguidos no domínio da evolução do relevo são, muitas vezes, pouco conhecidos.

O livro continua com uma Introdução geral à Geomorfologia de Portugal, da autoria de Denise e António de Brum Ferreira. Trata-se de uma excelente síntese, usando uma linguagem clara e acessível a não especialistas. Quer pela forma, que privilegia uma visão globalizante, quer pela actualização das referências bibliográficas, trata-se de um texto muito útil, que estabelece um quadro geral da Litologia, da Tectónica e das formas de relevo no conjunto do país, sem esquecer os aspectos distintivos das diferentes regiões estruturais e das zonas dentro do Maciço Hespérico. Quando se compara a litologia com o relevo, rapidamente nos apercebemos de que a constituição geológica, só por si, não explica os profundos contrastes existentes no país. Há que lançar mão da posição de Portugal no contexto das placas litosféricas e compreender como essa posição vai condicionar a evolução recente do território e a distribuição das principais massas montanhosas. Deste modo, o papel da neotectónica é claramente enfatizado, contra a antiga visão estática em que as formas de relevo se ficavam a dever essencialmente aos diferentes graus de resistência das rochas à meteorização e à erosão. O papel das movimentações tectónicas recentes ajuda-nos, inclusivamente, a compreender como se articulam entre si as superfícies de erosão, tema particularmente caro às escolas clássicas de Geomorfologia. Com efeito, segundo os autores, a existência de uma superfície única ou de várias superfícies escalonadas depende, em última análise, do tipo e intensidade de movimentos tectónicos que as afectaram. Assim poderemos ter, nas áreas situadas no interior da Península, uma única superfície poligénica (a Meseta). Na região planáltica do Norte da Beira, encontramos várias superfícies escalonadas, testemunhando uma tendência geral para o levantamento. Em áreas como o Minho, constituídas por um mosaico de compartimentos tectónicos de pequenas dimensões, que podem ter sofrido movimentações diferenciais, o estudo das superfícies de aplanamento torna-se muito complexo e difícil, dadas a multiplicidade dos níveis, a sua pequena extensão e a falta de depósitos correlativos, geralmente mal conservados num clima bastante húmido e numa posição próxima do litoral, onde as variações quaternárias do nível do mar criaram repetidas variações do nível de base.

O Capitulo II é da autoria de Mariano Feio e trata do Baixo Alentejo e serras envolventes. Segue-se, do mesmo autor, uma parte importante do Capitulo III, em que estuda o Alto Alentejo (em colaboração com António Martins). Nestes capítulos, Mariano Feio faz uma descrição interpretativa de muitos dos acidentes mais relevantes no Alentejo. Trata-se de uma área difícil, dado o carácter muito pouco acidentado, digamos até, monótono, do relevo. Para ajudar os leitores, foram inseridos mapas geomorfológicos de pormenor dos diferentes sectores, bem como diversos perfis projectados.

O texto parece muito útil como guia para demoradas viagens ou para a interpretação do relevo. Para quem tenha um conhecimento superficial do Alentejo, torna-se difícil assimilar toda a informação apresentada; parece-nos que um texto mais sintético teria sido mais eficaz. O trabalho resulta essencialmente da investigação levada a cabo para a tese de doutoramento de Mariano Feio, publicada em 1952, embora haja 
muitas referências a trabalhos bastante recentes, alguns deles do mesmo autor. Tratase, por isso, necessariamente, de um trabalho datado, que usa uma terminologia "davisiana". É hoje discutível o emprego de expressões como "rejuvenescimento lento por erosão" ou "vales maduros". Também a noção de peneplanície, que parece ter entrado no léxico geomorfológico relativamente a esta área do país, poderia ser substituída pela noção mais abrangente de "superfície de erosão". Com efeito, dada a utilização do conceito com significados diversos e por vezes divergentes, "o termo não é recomendável para uma aplicação de rotina na descrição e explicação das formas de relevo ${ }^{3 "}$ ". Mas algumas desactualizações em termos de terminologia são amplamente contrabalançadas com um carácter muito "moderno" no que diz respeito à análise da importância relativa entre a tectónica e a erosão. Nos diversos casos em que o problema se põe, a situação é sempre analisada cuidadosamente e muitas vezes é escolhida a hipótese mais mobilista, em que a tectónica recente é referida como a causa principal da arquitectura do relevo.

A problemática da Beira Baixa é rapidamente aflorada por Suzanne Daveau, retomando, no geral, os escritos de Orlando Ribeiro dos anos 40 e 50 do século passado, embora haja uma tentativa de actualização com base em estudos mais recentes de Brum da Silveira, João Cabral e Pedro Proença Cunha. Salienta-se o provável papel da tectónica no aumento do comando dos quartzitos sobre os xistos numa das estruturas geológicas mais relevantes da área, a crista de Vila Velha de Ródão.

O texto de António Martins sobre as Bacias do Baixo Tejo e Sado apresenta uma introdução muito interessante, justamente porque permite fazer um enquadramento da análise pormenorizada dos diferentes sectores considerados num quadro mais geral, o que aumenta a inteligibilidade do texto e nos parece uma boa escolha para atrair a atenção dos não especialistas. O autor privilegia, na sua análise, a bacia do Tejo, que constituiu o tema da sua dissertação de doutoramento. Na bacia do baixo Tejo, a existência de diversas coberturas detríticas contribui para uma certa monotonia em termos geomorfológicos e litológicos e dificulta a identificação das diferentes unidades. Esta distribuição dos depósitos da bacia do Tejo tem consequências na ocupação humana; assim, os planaltos cobertos por formações sedimentares terciárias, cuja porosidade contribui para uma certa aridez, estão plantados de pinheiros. Apenas os vales cobertos por aluviões permitem alguma agricultura. A espessura, relativamente pequena, das formações das bacias do baixo Tejo e Sado não permite que haja um descolamento da cobertura sedimentar em relação ao soco hercínico. Por isso, as formas do relevo mostram uma diminuta movimentação estrutural. Predominam as estruturas aclinais e monoclinais de fraco pendor. Porém, a falta de estruturas tectónicas de dobramento, como aquelas que encontramos na orla, não significa que não existam movimentos tectónicos recentes. A esse respeito, o autor apresenta um esboço geomorfológico rico de pormenores, em que o controlo estrutural exercido pelo prolongamento da falha do Ponsul e por outras falhas, de direcção semelhante, na passagem do Tejo pelas cristas quartzíticas de Ródão se torna muito claro. O estudo pormenorizado dos aplanamentos permitiu definir um nível bem desenvolvido, designado como nível de Mora-Lamarosa, que corresponde ao primeiro embutimento da rede de drenagem nas superfícies culminantes, cobertas pelos depósitos terciários. Este nível liga-se depois ao terraço mais

3 Goudie A S (2004) Encyclopedia of Geomorphology, vol. 2. Routledge, London and N. York, 772 pp. 
alto e permite, pela sua extensão e regularidade, estabelecer correlações com as áreas envolventes. $\mathrm{O}$ estudo pormenorizado dos terraços permite extrair algumas conclusões interessantes:

1. Aparecem a altitudes diferentes de um lado e outro do Tejo, na área de Vila Velha de Ródão, o que significa que a falha do Ponsul teve movimentação tectónica recente;

2. No troço NE-SW, entre o Entroncamento e a região de Lisboa, os terraços limitam-se praticamente à margem esquerda do rio. Esta dissimetria do vale só pode explicar-se recorrendo à manutenção da movimentação tectónica durante o Quaternário, o que aliás se comprova pela sismicidade histórica dessa área;

3. Verifica-se que, nas áreas soerguidas, apenas existem rechãs talhadas na rocha e não ocorrem terraços. Pelo contrário, os terraços multiplicam-se nas áreas deprimidas do vale do Tejo.

No capítulo sobre a Estremadura, Suzanne Daveau engloba toda a área compreendida entre o baixo Mondego e os baixos Tejo e Sado. Praticamente toda essa área se encontra inserida na Orla Ocidental Meso-Cenozóica e, por isso, a apresentação se inicia com uma breve história da respectiva evolução geológica. Segue-se uma análise dos aspectos mais representativos das diversas áreas a considerar (Maciço Marginal de Coimbra/serra do Buçaco, serra da Boa Viagem, serra de Ancião, Maciço Calcário Estremenho, vale tifónico das Caldas da Rainha, serra de Montejunto, colinas ao Norte de Lisboa, serra de Sintra e serra da Arrábida). A simples enumeração de todos estes acidentes geomorfológicos basta para mostrar a grande variedade em termos geológicos e geomorfológicos e a impossibilidade de fazer referência a todos os aspectos relevantes. A selecção é, por isso, pessoal. O Maciço Marginal de Coimbra é considerado como tendo fortes analogias com o Relevo Marginal, que podemos encontrar na área a Sul do Porto. Suzanne Daveau afirma claramente que as fases mais recentes da surreição daquele maciço são posteriores à elaboração de uma parte da plataforma litoral. Também nos chamou a atenção a referência aos depósitos da Chã da Mata, situados a altitudes bastante elevadas $(240 \mathrm{~m})$, o que sugere que esta área sofreu um processo de levantamento bastante significativo durante o final do Cenozóico. O mesmo se pode dizer da serra da Boa Viagem, com o seu topo a $257 \mathrm{~m}$, e a sequência de terraços marinhos que apresenta, nomeadamente na área do Farol. A existência de areias dunares na vertente ocidental da serra dos Candeeiros, a 290m, poderá, também, comprovar movimentos quaternários de subida, que parecem acentuar-se nos sectores actualmente mais elevados do limite interior da plataforma litoral. Uma situação idêntica tem lugar na serra de Montejunto, onde as areias litorais aparecem a 300m. Na serra de Sintra, os depósitos litorais iniciam-se a $250 \mathrm{~m}$, o que prova a origem marinha de uma série de rechãs escalonadas e inclinadas em direcção ao mar. As transgressões marinhas do final do Cenozóico também se podem identificar em Lisboa, onde teriam "avançado" até às Avenidas Novas. O topo aplanado de Monsanto, que culmina a $228 \mathrm{~m}$, poderá, também, ficar a dever-se à acção do mar. A serra da Arrábida, na região próxima do anticlinal do Formosinho, é o único local do país onde não se encontra plataforma litoral. Mas ela aparece a Oeste, na plataforma do Cabo, a 140m e em Sesimbra a 240m, subindo, a partir daí, rapidamente, até aos $321 \mathrm{~m}$, um pouco a Leste de Sesimbra.

O capítulo sobre a Cordilheira Central, também da autoria de Suzanne Daveau é o mais longo dos capítulos do livro (21 páginas). Esse facto poderá explicar-se não só 
pela investigação da autora nesta área, que remonta a 1969, mas também porque, devido à existência na periferia da Cordilheira de depósitos anteriores e correlativos da sua surreição - facto que está longe de ser comum nas outras montanhas do país - esta é uma área-chave para a compreensão da evolução geomorfológica de uma parte significativa do território. Antes de entrar na caracterização da Cordilheira, Suzanne Daveau faz um breve historial da investigação que sobre ela se tem feito. A esse respeito refere-se uma frase muito significativa de P. Birot (1946): "O relevo actual não é um simples mosaico de blocos e não é também uma escadaria de superfícies de erosão embutidas. É qualquer coisa de intermédio". Esta frase pode funcionar como um fio condutor para a compreensão de toda a Cordilheira, e mostra, desde logo, a complexidade de que o seu estudo se reveste. A eventual dificuldade de leitura decorrente dessa complexidade é compensada pela existência de uma cartografia clara e de diversos perfis projectados que ilustram bem o desenvolvimento topográfico destas montanhas. Numa primeira análise resulta claro que a fachada NW da cordilheira é mais abrupta e rectilínea que a fachada SE. Os cursos de água, ao contrário do que seria de esperar numa área que é a mais elevada do país, não têm um traçado centrífugo, mas geralmente orientam-se paralelamente à montanha, o que só por si traduz um intenso controlo estrutural. A Cordilheira Central desenvolve-se na Zona Centro-Ibérica do Maciço Hespérico; desse facto decorre a existência de xistos do Complexo Xisto-Grauváquico, de algumas faixas de quartzitos ordovícicos e de diversos tipos de granitos hercínicos. A fisionomia das serras está muito dependente da sua constituição litológica e o mesmo se pode dizer relativamente à sua ocupação humana. A forma como o Mondego e o Zêzere se dispõem, com um primeiro sector em que drenam em direcção do centro da Península, faz suspeitar que eles se dirigiam primitivamente para as bacias interiores da Meseta e que só depois a respectiva rede de drenagem terá sido capturada, passando a drenar no sentido Oeste. Essa drenagem para Leste prevalecente durante o Paleogénico seria contemporânea de uma cobertura arcósica, apenas conservada nos compartimentos abatidos. Suzanne Daveau examina em seguida cada uma das serras envolvidas na Cordilheira Central (Estrela, Açor, Lousã, Gardunha e serras ao Sul do Zêzere), bem como a vertente NW e as "terras baixas de xisto a SW da Cordilheira Central". Merece uma referência especial o chamado "Fosso do Zêzere" e também a Cova da Beira, depressão algo enigmática, situada entre a serra da Estrela a NW, a serra da Gardunha, a Sul, e a superfície da Meseta a Leste. Para Suzanne Daveau, o progressivo levantamento tectónico do sector onde o Zêzere se encaixa, a jusante da Cova da Beira, poderia explicar o alargamento do vale na área a montante, originando a referida depressão. O levantamento da Cordilheira Central inicia-se no final do Miocénico, quando as falhas com direcção NE-SW começam a jogar, daí resultando formações detríticas que mobilizam clastos com origem no Complexo Xisto-Grauváquico. Na bacia de Sarzedas, no sopé $\mathrm{SE}$, estes depósitos são sobrepostos por materiais do tipo raña, que poderão conotarse com a transição Pliocénico-Quaternário. Porém, estas mesmas formações estão afectadas por uma intensa deformação tectónica de tipo compressivo, o que mostra que a Cordilheira Central continuou a sofrer movimentação durante o Quaternário.

O Norte da Beira foi estudado por Brum Ferreira que publicou a sua tese sobre esta região, em 1978. No texto incluído no volume em apreço faz-se uma síntese das ideias principais contidas na tese acima referida. A área estudada pode considerar-se dividida em três grandes sectores: Meseta, planaltos centrais e montanhas ocidentais. A superfície da Meseta é a continuação da Meseta espanhola. Desenvolve-se desde altitudes de 950 a 1 000m até 400-450m em Vila Nova de Foz Côa, o que, só por si, 
demonstra uma clara deformação tectónica. Trata-se de uma superfície de grande regularidade, acima da qual existem alguns relevos residuais, como a serra da Marofa e o monte de S. Gabriel, ambos desenvolvidos em quartzitos. A Oeste do Côa, a superfície torna-se muito menos regular do que na área fronteiriça, onde é de uma perfeição impressionante. Em Portugal, está fossilizada por arcoses, em Nave de Haver. Perto da serra da Marofa encontram-se depósitos grosseiros contemporâneos das rañas. A cobertura, em Espanha, é muito mais espessa e complexa, constituindo a bacia de Castelaa-Velha. Uma vez que não é possível identificar superfícies escalonadas, correlativas de diferentes fases erosivas, admite-se que é poligénica. O rebordo ocidental da Meseta corresponde ao grande desligamento Bragança-Manteigas, também responsável pela abertura da bacia tectónica de Longroiva, em que é possível observar o soco xistento cavalgando as arcoses paleogénicas. Nos designados "planaltos centrais" já não encontramos uma superfície única, mas diversas superfícies de erosão, com diferentes idades. $\mathrm{O}$ autor considera a existência de uma superfície culminante (que corresponde ao planalto da Nave) e uma superfície dita fundamental. Esta última seria contemporânea da superfície da Meseta. Abaixo da superfície fundamental, existem ainda uma ou duas superfícies inferiores, embutidas naquela. Os planaltos centrais terminam contra uma outra escarpa NNE-SSW, que corresponde ao outro grande desligamento tardi-hercínico (Verín-Régua-Penacova).

Nas montanhas ocidentais, a movimentação tectónica é maior. O relevo torna-se mais complexo e as superfícies de erosão são menos claras. Além disso, elas estão mais bem conservadas nos granitos alcalinos do que nos calco-alcalinos. As montanhas que constituem este conjunto, são a serra do Montemuro (entre o Douro e o Paiva), o Maciço da Gralheira (entre o Paiva e o Vouga) e a serra do Caramulo (a Sul do Vouga). Dum modo geral, as superfícies existentes nestas serras estão deformadas, como é o caso da superfície de topo da serra do Caramulo, claramente balançada para Oeste. Na serra do Arestal, que faz parte, com a de Freita, do Maciço da Gralheira, as superfícies aparecem 250 a 350m mais baixas do que na de Freita, o que sugere um desnivelamento tectónico feito ao longo de uma falha de direcção NW-SE. Esta mesma falha será responsável pela espectacular cascata do rio Caima, designada como "Frecha da Mizarela". A Plataforma do Mondego corresponde a uma superfície drenada pelo Mondego e seus afluentes, situada entre a serra do Caramulo e a Cordilheira Central. O facto de estar fossilizada por uma cobertura de arcoses do Eocénico final permite a Brum Ferreira considerar que ela é correlativa da superfície da Meseta. A bacia de Mortágua situa-se no prolongamento da falha que soergue a serra do Caramulo. Também aqui se encontram depósitos arcósicos. Porém, a cobertura da base da bacia é mais antiga e corresponde aos grés do Buçaco (Cretácico), cobertos por formações pós-tectónicas, com clastos de xisto. A margem sul do vale do Douro faz parte da área estudada neste capítulo, uma vez que limita o Norte da Beira. Admite-se que o grande encaixe do Douro nas Arribes del Duero se deve a uma captura recente; esse encaixe ter-se-á feito a partir de um nível embutido nos Planaltos Centrais. Isso parece significar que, nesta área, existiu um pré-Douro anterior ao encaixe actual e anterior à captura do troço superior do Douro, o qual se dirigia para o Atlântico.

O Noroeste (Minho e Trás-os-Montes Ocidental) é o capítulo seguinte do livro. É assinado, tal como o anterior, por Brum Ferreira, que refere o facto de esta área nunca ter sido objecto de um estudo geomorfológico de conjunto. A repartição do relevo a Norte do Douro tem semelhanças com o que se passa a Sul: a superfície da Meseta estende-se para Leste do Sabor. Entre o Sabor e o desligamento Régua-Verín 
desenvolve-se uma série de planaltos. A Oeste do desligamento encontra-se uma morfologia mais acidentada, que corresponde a uma maior fragmentação tectónica e a uma maior subida relativa. Trata-se de um conjunto de montanhas, que formam a barreira de condensação entre o Minho e Trás-os-Montes. Mais para Oeste, o Minho ocidental apresenta uma grande originalidade no conjunto do relevo de Portugal, com uma série de vales largos e vertentes abruptas, com orientação ENE-WSW. O desligamento Régua-Verín tem um papel estruturante nesta organização do relevo e, por isso, Brum Ferreira começa a sua análise pela geomorfologia das áreas ligadas a este grande acidente. $\mathrm{Na}$ área de Chaves, os níveis de aplanamento mais altos estão embutidos uns nos outros, enquanto os mais baixos estão claramente deslocados pela tectónica. São descritos os depósitos da bacia de Chaves e descartada a hipótese de que poderiam tratar-se de terraços do Tâmega. Correspondem, isso sim, a antigas coberturas de grés feldspáticos, conservadas num compartimento abatido e cobertos por materiais mais angulosos e ricos em caulinite. Seguindo o alinhamento Régua-Verín, a Sul da veiga de Chaves, encontram-se diversas depressões: Vidago, Pedras Salgadas, Telões e Vila Real. O mais curioso é que o Tâmega, em vez de seguir o caminho dessas depressões e a sua orientação NNE-SSW, vai dirigir-se para SW. Aparentemente, o Tâmega corresponde a uma vaga de erosão regressiva nascida a partir do Douro ("o verdadeiro rio importante e relativamente antigo da região"). O traçado do rio é, assim, relativamente recente, tal como no caso do Lima (o que poderia comprovar-se pela drenagem deficiente da depressão de Ginzo de Limia). A Leste de Chaves, a superfície da Padrela, claramente soerguida ao longo da falha Régua-Verín, estende-se até cerca de Alijó, já próximo do Douro, onde entra em contacto com a superfície inferior dos planaltos centrais do Norte da Beira. Esse facto leva Brum Ferreira a considerar que a superfície da Padrela seria equivalente à superfície fundamental dos planaltos centrais do Norte da Beira. Por sua vez, os topos da Padrela, da Falperra e do Alvão corresponderiam à superfície culminante. No caso da serra do Alvão, a superfície fundamental penetra claramente em regolfo no seio da superfície culminante, cujo topo se situa a $1280 \mathrm{~m}$. Parece-nos de registar a convergência que estas ideias apresentam com a teoria da superfície gravada de Martín-Serrano na obra El relieve de la region occidental Zamorana (Instituto de Estudios Zamoranos, Diputation de Zamora, 1989, 289 pp.). Porém, no caso do modelo de Martín-Serrano admite-se que não há uma diferenciação temporal entre a formação dos níveis culminantes e da superfície fundamental; aqueles corresponderiam a afloramentos de rochas mais resistentes ou menos diaclasadas e manter-se-iam em posição dominante durante toda a evolução geomorfológica subsequente, constituindo, em muitos casos, relevos residuais do tipo inselberg. A respeito do escalonamento das superfícies, Brum Ferreira critica o modelo que Coudé Gaussen desenvolveu para a serra do Gerês, em que se admite a existência de cinco níveis diferentes, dado que alguns deles, numa área que sofreu uma tectónica recente, estão deslocados e terão um significado local.

O Minho ocidental é caracterizado pela grande fragmentação do relevo e pela existência de vales largos, com uma clara orientação ENE-WSW. Uma outra direcção, que varia entre N-S e NW-SE, acaba por produzir uma quadrícula de blocos, aparentemente movimentados ao longo de falhas com movimentação essencialmente vertical, já que os desligamentos não terão deixado sinais evidentes. No Minho, as superfícies de aplanamento estão mais degradadas que noutras áreas do Maciço Hespérico. O seu estudo é dificultado pela inexistência de depósitos. A humidade do clima e proximidade do nível de base terão também contribuído para uma significativa degradação das 
escarpas originais, o que dificulta a identificação da tectónica recente. Os vales dos rios minhotos são a grande originalidade do relevo do Minho. Serão devidos ao recuo das vertentes paralelamente a si próprias? Ou serão verdadeiros graben? De um modo geral são vales mal calibrados, com larguras muito variáveis, e Brum Ferreira inclinase para a hipótese de a irregularidade e a ampla abertura dos vales se relacionar com a existência de alvéolos resultantes da alteração química em rochas graníticas.

Além de uma referência aos depósitos do Prado, Alvarães e S. Pedro da Torre, atribuídos ao Placenciano, Brum Ferreira analisa a problemática dos terraços dos rios Minho e Lima. A falta de um estudo de conjunto conduziu a uma grande variedade de interpretações, às quais Brum Ferreira contrapõe um modelo segundo o qual, a Norte do rio Ave, existe uma superfície poligénica ligando a estreita plataforma litoral e os amplos vales dos rios minhotos. A litologia granítica e a humidade que persiste mesmo durante o Verão teriam contribuído para um alargamento dos vales e para a degradação das escarpas, que se tornam de identificação difícil. O conjunto faria lembrar "uma versão não submersa das rias galegas", profundamente contrastante com o Norte da Beira, "onde os rios se encaixam profundamente na plataforma litoral", sugerindo "ou uma subsidência tectónica de Sul para Norte, ou uma diminuição, nesse sentido, da taxa de levantamento durante o Quaternário".

O capítulo de António Ribeiro sobre o Nordeste (Trás-os-Montes oriental) traznos uma linguagem ligeiramente diferente, a linguagem de um geólogo, especialista em Tectónica e em que a sensibilidade para a Geomorfologia se casa admiravelmente com um profundo conhecimento da área estudada, dando-nos uma visão integradora e clarificadora do conjunto da evolução geomorfológica durante o Cenozóico. Sob o ponto de vista geomorfológico, Trás-os-Montes oriental corresponde essencialmente a um retalho bem conservado da superfície da Meseta. Acima dessa superfície encontramse, em posição culminante, relevos residuais de posição e de dureza. Atapetando a superfície da Meseta existem depósitos do tipo raña, que se prolongam para Leste, coroando o enchimento sedimentar da bacia do Douro. O grande desligamento Bragança-Manteigas é a principal estrutura tectónica da região, produzindo uma deformação da superfície da Meseta e, em alguns casos, dos terraços quaternários. Este desligamento produz "bacias de pull-apart em curvas permissivas (releasing bends) e dorsais de push up em curvas restritivas (restraining bends)". Também existem movimentações em semi-horst (serra de Bornes) e semi-graben (bacia de Mirandela) "com basculamento assimétrico das superfícies de referência". A superfície da Meseta é fossilizada, como acontece a Sul do Douro, por depósitos paleogénicos. Uma parte importante dela está coberta por depósitos assimiláveis às rañas para os quais é proposta uma idade na transição entre Pliocénico e Quaternário (Vilafranquiano).

Cerca de $100 \mathrm{~m}$ abaixo da superfície da Meseta existe um terraço rochoso, mais bem conservado nos afluentes do que no Douro, e com depósitos do tipo raña. Nos xistos mais brandos é ainda possível identificar um terraço rochoso inferior. E só abaixo dele se encontram os terraços quaternários. A idade do terraço rochoso superior é inferida a partir das curvas da variação do nível do mar e estaria compreendida entre 2,4 e 2,6 milhões de anos. A partir destes dados é possível fazer uma proposta da evolução do relevo: assim, entre o Cretácico superior e o Miocénico superior, ter-se-ia desenvolvido uma drenagem em regime endorreico, dirigida para o interior da bacia do Douro. Esta rede de drenagem situar-se-ia pouco acima do nível do mar seu contemporâneo e seria responsável pelo afeiçoamento da superfície culminante da Meseta. A partir do Miocénico superior esta superfície sofreria uma importante deformação. Por último, 
próximo da fronteira Pliocénico-Quaternário tiveram início os movimentos verticais, responsáveis pelo levantamento de conjunto da Meseta norte, com taxas compreendidas entre 0,13 a 0,35/ano, cuja ocorrência corresponderia à transformação do regime da margem passiva ibérica numa margem activa. Esta movimentação teria originado um retoque plio-quaternário, correlativo da formação dos depósitos tipo raña. Teria sido o levantamento da Meseta, originando uma rápida descida do nível de base, que desencadeou a captura do Douro. Esta seria contemporânea da elaboração do terraço rochoso superior. Este terraço, que não existe nas áreas das Arribes del Duero, só aparece a jusante da confluência com o Tua, o Sabor e o Côa, o que confirmaria a ideia, já apresentada no texto de Brum Ferreira, de que o Douro internacional corresponderia à garganta de ligação entre os dois segmentos da paleo-drenagem que se reuniram para formar o Douro: uma drenagem atlântica dirigida para Oeste e uma drenagem dirigida para o interior, para a bacia de Castela-a-Velha.

O último capítulo do livro é da autoria de Ana Ramos Pereira e é consagrado à Faixa litoral, conceito que abrange, quer a plataforma litoral, quer a plataforma continental e a linha móvel entre ambas (a linha de costa). A plataforma litoral corresponde a uma superfície aplanada adjacente ao mar, geralmente limitada para o interior por uma escarpa, de origem tectónica. É, segundo a autora, uma designação puramente morfológica, utilizada unicamente nesta acepção, uma vez que a escarpa, que a delimita internamente, resulta de uma deformação posterior a alguns dos depósitos que frequentemente cobrem a plataforma. Esses depósitos, sendo geneticamente variados, não autorizam a que se usem, como sinónimas, as expressões "plataforma litoral" e "plataforma de abrasão". Existe uma apreciável variedade ao longo da plataforma litoral portuguesa, ainda insuficientemente conhecida no pormenor. A autora apresenta dois exemplos. No caso da plataforma litoral do Alentejo, a formação mais antiga é a designada "Formação Vermelha". Esta formação sofre abarrancamento por um sistema de leques aluviais resultantes do levantamento da serra do Cercal, que limita a plataforma pelo interior. Estes leques aluviais correspondem a escoadas lamacentas ou cascalhentas, contendo elementos da "Formação Vermelha". Testemunhos desta "Formação Vermelha" estão também presentes no topo da serra, o que demonstra que a plataforma litoral fazia parte de uma extensa superfície de aplanamento, que se estendia para o interior do Alentejo e onde, na faixa mais próxima do litoral, objecto de estudo, os depósitos passam lateralmente de depósitos de praia a fluviais e eólicos. A "Formação Vermelha" corresponderia ao Placenciano ou Zancleano e seria correlativa de condições climáticas progressivamente mais áridas. Essa aridez seria reforçada na fase de formação dos leques aluviais, provavelmente equivalentes à "Formação de Panóias" (fase tectónica Ibero-Manchega II). Seguir-se-ia uma fase transgressiva correlativa da "Formação de Aivados-Bugalheira". A partir daí predomina uma dinâmica essencialmente dunar, a que corresponderiam duas formações distintas: a "Formação do Malhão" (também deformada tectonicamente) e a "Formação de Aivados", que inclui as dunas consolidadas do forte e da ilha do Pessegueiro. Dum modo geral, as fases de construção de dunas corresponderiam aos períodos regressivos do Quaternário.

A plataforma litoral da região do Porto foi alvo da nossa tese de doutoramento, apresentada em 1991. Algumas das conclusões desse trabalho foram sintetizadas por Ana Ramos Pereira e demonstram semelhanças muito significativas com aquilo que ficou dito sobre o litoral alentejano. Na região do Porto há um predomínio de depósitos fluviais ou de tipo leque aluvial dentro dos depósitos mais altos e mais antigos. Também aqui o limite interior da plataforma litoral é uma escarpa de falha, posterior 
à formação dos depósitos mais antigos, cuja idade é desconhecida mas em que se aponta para o Pliocénico ou, eventualmente, Miocénico. Uma das originalidades da área diz respeito à existência de um degrau situado entre os depósitos de fácies fluvial e os depósitos marinhos. Esse degrau é interpretado com uma escarpa posterior aos depósitos fluviais, cuja movimentação teria propiciado o desenvolvimento de um sistema de três níveis de "praias levantadas", identificadas na área de Lavadores, imediatamente a Sul da foz do Douro, e que se desenvolvem sempre abaixo dos 40m. Esse degrau teria, por isso, funcionado como uma arriba. A autora do capítulo conclui que, de modo geral, a plataforma litoral é uma superfície poligénica. Não é uma simples plataforma de abrasão marinha e nem sequer os seus depósitos correlativos são exclusivamente marinhos. Apresenta-se bastante diferenciada ao longo do litoral português, aparentando poder organizar-se em compartimentos diversos, correspondendo a regimes tectónicos diferenciados de subidas ou de descidas de maior ou menor amplitude. Também relativamente à plataforma continental, forma de relevo aparentada com a plataforma litoral, mas hoje submersa, se podem considerar diversos compartimentos (a Norte da Nazaré, entre a Nazaré e Setúbal, de Setúbal ao cabo de S. Vicente e Algarve) com características bastante diversas. A morfologia da plataforma continental está muito relacionada com a respectiva geologia, encontrando-se diversas formas estruturais (horst, costeiras e empolamentos ligados às estruturas diapíricas). Um dos aspectos mais interessantes relaciona-se com a existência de profundos canhões submarinos, que ora apenas acidentam a parte exterior da plataforma ora podem, nalguns casos (Nazaré, CascaisLisboa, Setúbal e S. Vicente), seccionar a própria plataforma. O bordo da plataforma pode estar em progradação ou em recuo (regradação). A situação de progradação está geralmente associada à proximidade de rios, que transportam abundantes sedimentos. Entre ambas as plataformas situa-se a linha de costa cujo significado é tratado em seguida. A sua posição e características "reflectem o equilíbrio ou o estádio de evolução para o equilíbrio entre o nível do mar, as condições do clima de agitação marítima, o afluxo de sedimentos e as condições tectónicas regionais". De um modo geral, nas áreas topograficamente deprimidas, frequentemente abatidas tectonicamente, predominam os fenómenos de sedimentação e a costa é, muitas vezes, arenosa, com praias e dunas bem desenvolvidas. Se os sedimentos não forem suficientemente abundantes o mar pode começar a entalhar arribas em antigos cordões dunares ou litorais. Em áreas que estão a sofrer levantamento gera-se um escalonamento de plataformas de erosão marinha e predominam os fenómenos de erosão, originando uma costa rochosa, de arriba.

O capítulo encerra com algumas reflexões sobre o carácter extremamente móvel da linha de costa à escala do tempo geológico/geomorfológico, mas também à escala histórica. Dada a intensa ocupação da faixa costeira, os problemas actuais de erosão revestem-se de acuidade particular, sendo necessário contar com esse facto e daí extrair conclusões muito pertinentes em termos do ordenamento do território.

Concluindo: num país com uma tão grande diversidade geológica, geomorfológica e mesmo climática, a unificação do saber geomorfológico é particularmente difícil, até porque a essa diversidade se acrescentam as diferentes perspectivas dos investigadores, resultantes das escolas a que pertencem e das influências sofridas ao longo do seu percurso científico. Efectivamente, seria muito desejável que existisse uma linguagem e um corpo doutrinário comum. Mas isso só será possível a partir da divulgação e discussão dos resultados das diversas investigações. Ora, a compartimentação desses saberes e a divulgação de resultados em teses, por vezes de circulação restrita, 
dificultam a discussão e comparação de resultados. Este volume dá uma contribuição importantíssima para essa síntese. A partir de agora, há um texto de onde é possível partir para tentar essa síntese. Num único volume, tem-se uma visão do "estado da arte" dos estudos geomorfológicos em Portugal, bem como uma bibliografia actualizada sobre as diferentes regiões do país. Tudo isto representa um grande avanço científico e uma ajuda indispensável para a investigação, para os estudantes a quem faltava um livro de síntese e para os cultores de outras especialidades científicas. Este texto deve fazer parte da biblioteca de todos os geógrafos e, por que não, também dos geólogos cuja formação no domínio da Geomorfologia nem sempre é a desejável.

É óbvio para todos nós que ainda há muito caminho a percorrer, no sentido de realizar a integração destes estudos num todo coerente. Este livro faz-nos lembrar a construção de um puzzle complexo. Agora que a maior parte das peças estão reunidas, apercebemo-nos de que o quadro resultante não é totalmente coerente. Mas foi indispensável fazer este primeiro trabalho, para avançar para a fase seguinte em que algumas áreas problemáticas serão clarificadas e aumentará a coerência entre os sectores mais bem estudados do puzzle.

Outra tarefa indispensável é a comparação com o que se passa do outro lado da fronteira, já que a interpretação feita em Espanha, com que partilhamos algumas paisagens e regiões estruturais e onde as formas e os depósitos atingem um desenvolvimento maior, permitirá enquadrar e quiçá contribuir para a resolução de alguns dos problemas com que hoje nos debatemos.

Como diria Antonio Machado: “.... al volver la vista atrás, se ve la senda que nunca se ha de volver a pisar". Como todo o "produto" científico, a imagem de Portugal que transparece neste livro é ainda um esboço, uma aproximação, necessariamente datada, de uma realidade por definição inatingível na sua integralidade. Porém, cumprida esta primeira fase, laboriosa e difícil, este livro é, sem dúvida, um excelente ponto de partida para avançar para novos desafios, para obter uma imagem cada vez mais bem focada e com maior resolução da realidade geomorfológica do país. 

ACTUALIZAÇÃO BIBLIOGRÁFICA 



\section{O ALGARVE VISTO DO CÉU UM DOCUMENTO GEOGRÁFICO IMPORTANTE E DE GRANDE BELEZA}

Carminda CaVACO ${ }^{1}$

O Algarve visto do céu, um excelente livro de fotografias, do arquitecto Filipe Jorge, encanta, estou certa, muitos dos seus leitores, geógrafos e não geógrafos. São muitas as fotografias, a diferentes escalas, e ricos os seus pormenores. Acompanhamnas textos de enquadramento, em português e em inglês, de um conjunto de autores, especialistas e profundos conhecedores da região, de Fernando Pessoa, João Bernardes, José Horta Correia, Miguel Reimão Costa a João Guerreiro, que dispensam qualquer apresentação. A edição é da ARGUMENTUM (2005) e contou com o patrocínio da Associação de Municípios do Algarve e da Faro Capital Nacional da Cultura 2005.

A apresentação deste belo livro é para mim uma ocasião de revisitar o Algarve, a diferentes escalas e sob diversas perspectivas, muitos anos depois, dezenas de anos depois, do início da aceleração dos processos de mudança, a qual acompanhei, e até mesmo vivi de perto, e que lhe permitiram ultrapassar as crises das suas economias tradicionais, de base agrícola, piscatória e conserveira, contrariar a fuga da sua gente, das suas elites e dos menos dotados, para outras regiões do país e para muitos destinos clássicos de emigração, tornando-se numa das regiões portuguesas mais desenvolvidas, no sentido global do termo, e de maior projecção europeia e mundial. Revisitação aliás facilitada pela inclusão no livro de algumas fotografias antigas, de quase meio século, que ajudam a recordar o passado e evidenciam as próprias intensidades da mudança e do desenvolvimento.

O Algarve visto do céu é, na verdade, e antes de mais, um vasto conjunto de imagens muito belas e muito actuais, que cobrem todo o território algarvio, do litoral ocidental e meridional às superfícies que dos seus cimos algo montanhosos descem para Norte, com alguma suavidade, ao encontro das planuras do Baixo Alentejo, e evidenciam a sua unidade e a sua diversidade. Imagens das massas de água oceânicas de um azul-turquesa ou esverdeado, em harmonia com o azul dos céus, ora revoltas ora calmas, no encontro das arribas vigorosas da costa ocidental ou das arribas rendilhadas da costa do Barlavento, dos cordões dunares, com suas barras instáveis, das embocaduras dos rios e ribeiras, dos sapais, mouchões, esteiros e salinas, sobretudo no Sotavento. Salinas ainda tradicionais ou já modernas e de malhas bem

1 Investigadora do Centro de Estudos Geográficos e Professora Catedrática da Faculdade de Letras da Universidade de Lisboa. 
mais largas, expressas em geometrismos reluzentes e prateados, em contraste com as superfícies líquidas e espelhadas das barragens onde os contornos são sinuosos, ao sabor dos caprichos da topografia dos xistos onde foram construídas. Imagens a que se juntam, pela vizinhança, as das pequenas "cidades de plástico", também ele luzidio, da campina de Faro-Olhão, pela modernização das técnicas tradicionais de forçagem para produção de primores hortícolas, no que o Algarve litoral cedo se especializara, contando primeiro com a cabotagem e depois com o comboio da noite, que levava para a capital do Reino e da República o correio, alguns passageiros e os produtos da horta e dos pomares, e na Primavera também as favas e ervilhas dos campos de sequeiro do Barrocal.

Um percurso "pelas imagens do céu" que nos são proporcionadas permite-nos, com efeito, viajar das paisagens fortemente humanizadas do litoral aos desertos humanos das terras serranas ou das vertentes do Mira e do Guadiana; observar pormenores das estruturas antigas do povoamento e das cidades, como em muitas fotografias de Alcoutim e do Carvoeiro, com o seu velho casario acompanhando as curvas de nível, ou noutras fotografias que evidenciam os cascos antigos de cidades como Silves, Tavira ou Faro, com suas muralhas e castelos; fotografias que Filipe Jorge combinou hábil e criteriosamente com algumas outras de arquivo, de modo a evidenciar os sentidos e os próprios ritmos das expansões do casario. Permite-nos identificar, por exemplo, a antiga organização do espaço urbano de Tavira por uma e outra margem do Gilão e a sua ligação por uma velha ponte romana, e a que não escapou, no bater da chapa, a permanência de um velho arraial de armação de atum, símbolo do mais recente ciclo de desenvolvimento económico da cidade antes do turismo, embora adaptado a complexo hoteleiro moderno. Permite-nos reconhecer a génese Vila Real de Santo António, com o seu geometrismo planeado à imagem da reconstrução da Baixa de Lisboa, também ela pombalina, e a dignidade da sua fachada fluvial, justamente frente a Espanha, como convinha para a defesa dos direitos nacionais de comércio e sobre as pescarias nas costas da província, em particular nas do Sotavento, nomeadamente em Monte Gordo. Sem esquecer as estruturas e equipamentos modernos, dos muitos aldeamentos turísticos aos portos de recreio, às marinas e campos de golfe e ao novíssimo estádio do Algarve, passando pelas várias fases da construção e funcionamento do aeroporto de Faro, pelos grandes complexos logísticos dos sistemas de distribuição e pelos grandes centros comerciais.

São fotografias que jogam não apenas com diferentes escalas mas igualmente com diferentes perspectivas, acompanhadas por textos também eles traduzindo diferentes sensibilidades, que agradarão tanto os naturalistas e os que preferem fugir aos humanos, ou os nostálgicos de um velho Algarve dos algarvios - obviamente de uma dada geração de algarvios, que integrara as mestiçagens anteriores, dos nórdicos aos africanos e orientais - e não menos agradarão os que amam a presença e a proximidade dos seus semelhantes e valorizam a compreensão das suas obras e a criação dos seus territórios ao longo dos tempos e no presente, com projecção no futuro.

Impressiona, desde logo, a fotografia de abertura, uma imagem Land Sat de todo o Algarve, numa escala adequada para se apreciar correctamente a ocupação da totalidade do território: nesta sobressai, de imediato, um espaço que permanece vazio na sua grande extensão, nomeadamente na costa vicentina e nas serras de Monchique e Caldeirão, espaços montuosos deixados aos processos naturais, ainda predominantemente rudes e com algumas manchas com tonalidades sugestivas de aridez, ou das queimadas dos grandes incêndios dos últimos anos, onde são muito escassas, difusas e mesmo ténues 
as marcas de ocupação humana. Espaços que são domínio de matos densos, como antes da Campanha do Trigo, com predomínio cada vez mais acentuado de estevas e aqui e além de montado, quando mais húmidos, que foram terra de pastoreio de rebanhos de caprinos e ovinos e de varas de porcos e também de transumância de colmeias, de carvoeiros vivendo do fabrico e da exportação de carvão de sobro e azinho para as cidades andaluzas, acessíveis pelo Guadiana, por mar e pelo Guadalquivir, que o pagavam bem melhor que as do Algarve, sem esquecer o corte de árvores para a construção de barcos, que também fora preciso disciplinar e mesmo proibir. Matos que, sob a pressão da sobrevivência alimentar de populações rurais que se tornavam mais numerosas, nomeadamente durante o século XIX e na primeira metade do século XX, foram dando lugar a cultivos primitivos, em que às arroteias se seguiam queimadas e às parcas colheitas longos pousios, e que mais tarde, quando os meios de sobrevivência se tornavam ainda mais escassos, foram seguidos de colonização e povoamento, num processo topograficamente ascendente, pelas populações periféricas, o que a toponímia atesta com o desdobramento dos nomes das aldeias e sobretudo de simples lugares como, por exemplo, Marrocos de Baixo, de Cima e do Meio.

No fundo, um sertão que fora marginalizado pela economia tradicional, e continua sendo-o pelas economias modernas, em relação ao qual não vão bastando as políticas florestais, as ajudas ao desenvolvimento rural e muito menos as utopias de interiorização do turismo e de promoção de turismo rural e de ecoturismo, já que no turismo, como noutros sectores, quem comanda são as procuras, e com elas as sustentabilidades económicas, e não as boas vontades ideológicas e as acumulações de subsídios.

Mas nesta fotografia inicial do conjunto do território sobressai, de igual modo, a concentração das manchas do povoamento na planície litoral e sobretudo na frente marítima, um pouco também nas encostas mais suaves das superfícies miocénicas e na depressão periférica do Maciço Antigo, ao longo da qual fora mais fácil assegurar as deslocações este-oeste, desde o tempo dos Árabes, como o testemunha o alinhamento de algumas cidades históricas, com destaque para Silves, Loulé e Tavira, embora se não deva esquecer que todas estas gozaram de acessibilidade marítima, pelo Arade, pelo Ludo ou pelo Gilão. Testemunham que o Algarve sempre foi, ao longo da sua história, uma terra virada ao mar, com uma ocupação essencialmente costeira, mesmo quando esse mar não simbolizava apenas outros mundos e outras gentes e a possibilidade de trocas, de chegada de recursos complementares para uma economia que cedo deixara de ser autárcica e de novas e renovadas oportunidades de futuro, mas também invasões e ataques de corsários.

A estas escalas de conjunto e portanto, a estas distâncias do céu, também se podem ler com alguma facilidade os grandes contrastes na ocupação dos espaços rurais do Algarve litoral e do Barrocal, das terras planas e das encostas pedregosas, e até mesmo as cicatrizes das pedreiras de brita e do cimento, e identificar os matos também vazios de homens da Rocha dos Soidos, da Rocha da Pena, do Cabeço da Câmara, do Malhão ou de São Miguel. Destaco, para já, os arranjos dos campos do Barrocal, muitos algo recentes, com menos de um século, e algo conjunturais, fruto do esforço insano do homem nas despedregas feitas a picareta, aquando dos máximos demográficos dos anos 30 a 50 do século passado, sempre sob a pressão das necessidades de sobrevivência das populações camponesas, mesmo se também norteadas pelas oportunidades do mercado, e que se adivinham ainda hoje nas espessuras dos velhos valados que os limitam ou mesmo ponteiam, cujas funções de vazadouro se sobrepunham às de limite e protecção da propriedade privada. 
No fundo, são também neste caso o resultado das estratégias de sobrevivência das populações que não ousaram o êxodo proporcionado pelo caminho-de-ferro, os modestos empregos disponibilizados na polícia, na guarda fiscal ou no exército, ou nas oficinas dos caminhos-de-ferro e da CUF, do Barreiro, nem acompanharam a deslocalização, para empregar um termo muito em voga, das fábricas de cortiça de Silves e de São Brás de Alportel para a margem sul do Tejo, onde era bem maior a acessibilidade a novos mercados, internos e sobretudo externos. Populações para quem se tinham fechado os tradicionais caminhos da emigração para o Brasil, a Argentina ou a Venezuela e não se reabriam as portas de entrada nos EUA, Canadá e sobretudo na Espanha e na França, como veio a suceder nesta última nos finais dos anos 50, com intensidades que aliás desequilibraram totalmente as relações entre forças de trabalho e sistemas de cultivo e produção, e no seu seguimento, o avanço dos incultos e depois dos matos, o abandono de quase todos os cultivos e mesmo das parcas colheitas arbóreas, numa simples estratégia de recolecção moderna, apesar do desenvolvimento de novos fluxos humanos, primeiro sazonais e depois definitivos, o dos rurais sem terra do Baixo Alentejo, mesclando e enriquecendo um pouco mais culturas e tradições locais.

Nestas texturas complexas da ocupação e valorização das terras do Baixo Algarve destacam-se algumas clareiras, facilmente identificáveis em muitas das imagens que nos são proporcionadas, pela regularidade e homogeneidade das plantações de pomares de sequeiro e regadio. Tais clareiras aparecem associadas a grandes propriedades, de antigas famílias fundiárias nobilitadas pelas conquistas e descobertas, do Norte de África à Índia e ao Brasil. Terras de morgados, que mantêm o nome, muito tempo depois da sua apropriação pela nova burguesia regional, nacional e sobretudo estrangeira, nomeadamente espanhola, mas também italiana e inglesa, uma burguesia do comércio dos frutos secos e da cortiça, e sobretudo das épocas áureas da pesca e das conservas de peixe. Algumas outras grandes propriedades, morgados, quintas e mesmo herdades quando estendidas pelas encostas das serras de xisto, foram dando lugar a resorts e aldeamentos turísticos mais ou menos sofisticados, com lugar para zonas de caça e sobretudo campos de golfe, não menos exigentes em trabalho e por certo bem mais lucrativos. Destaco as muitas fotografias da Quinta do Lago, de Vale do Lobo e sobretudo de Vilamoura, cuja história fundiária e agrícola me é mais familiar.

Mas este belo livro, que convida à contemplação das suas imagens, é ao mesmo tempo um documento importante para o conhecimento, e não menos a promoção e divulgação do Algarve, a nível nacional e a nível internacional. Uma síntese das permanências e mudanças, das harmonias e das roturas e descontinuidades na ocupação do espaço, das suas malhas, estruturas e até funcionalidades, dos percursos do seu ordenamento, claramente simbolizados pelas magníficas fotografias das elegantes pontes de Portimão e Castro Marim, a beleza dos novos trevos das suas mui jovens autoestradas, as superfícies prateadas pelos raios do sol incidentes nos lagos interiores das não menos jovens barragens. Estas foram sendo construídas para responder a procuras crescentes de água por parte de populações também elas crescentes, de visitantes e não menos de residentes, que o Algarve tem contrastado fortemente com as demografias recessivas das outras regiões do país, e não apenas através da atracção e fixação de populações idosas e reformadas fugindo aos rigores dos Invernos nórdicos; e também para ultrapassar as velhas e repetidas carências estivais no abastecimento do precioso líquido das populações rurais, quando era preciso madrugar e ainda com o luar aparelhar as bestas com os cântaros de barro e procurá-lo em algum poço mais profundo ou melhor 
alimentado pela circulação subterrânea nos calcários, por vezes a quilómetros de distância da casa de residência.

O Algarve visto do céu é também um documento das identidades locais, como o comprovam as imagens espectaculares das açoteias de Olhão, as novas e as mais antigas, que são bem mais complexas, com os seus pisos embutidos, até ao mirante, e que evocam o Norte de África e as ligações intensas das suas comunidades piscatórias e marítimas com as populações do outro Al-Gharb. Açoteias de difusão comum à Fuzeta, aglomerado piscatório que acompanhou a dinâmica de Olhão como seu subúrbio residencial, e que com ele, com Cabanas, Monte Gordo ou Quarteira e a Luz de Lagos, partira das primitivas cabanas de colmo, substituídas por casas de pedra e cal só a partir dos séculos XVIII ou XIX e ainda facilmente observáveis nos meados do século $\mathrm{XX}$. Ou como o comprovam os castanheiros da serra de Monchique, neste caso especificidade botânica associada à natureza dos terrenos sieníticos e à frescura do clima, pela altitude e exposição aos ventos dominantes atlânticos e de Noroeste, sem esquecer a abundância de chuvas, ocasionalmente a presença de neve, em contraste com as terras baixas envolventes, como que "o penico do céu", na observação do povo; castanheiros que vêm assegurando madeiras para o artesanato local, mas que também produziam castanhas, facto único na província, evocado em versejos populares, como "as donzelas de Monchique são bonitas mas sem dentes, porque bebem água fria e comem castanhas quentes". Sem esquecer o contraste das moles sieníticas elevando-se a cerca de 900 metros com o soco de xisto em torno dos 400 metros, com os seus medronheiros e sobreiros, em cujo contacto se localizam as termas, velho recurso terapêutico, que fora muito procurado pelas populações de Lisboa e de todo o Sul, mesmo da Andaluzia, não obstante a difícil acessibilidade e a necessidade de mobilização do transporte por barco, pelo Guadiana para as do interior alentejano e as espanholas, pelo mar para as do litoral meridional e ocidental, e pelo Arade para umas e outras.

Especificidades também das terras drenadas e pantanosas, que acompanham as secções de jusante de muitos cursos de água, terras de sapais protegidas por restingas instáveis, como em Alvor, em Quarteira e na Ria de Faro-Olhão-Cacela. Nestas destaco as várzeas de Quarteira, tema de fotografias verdadeiramente didácticas, com muitos problemas de drenagem, especialmente antes da fixação pelo homem do leito rectilíneo da secção de jusante da ribeira do mesmo nome: hoje terras de aldeamentos e campos de golfe, antes terras de pequenas hortas familiares de renda, os "Quartos", para cultivos primaveris e estivais, como o milho e a batata doce, regados com picotas e regadores a partir de valas por onde circulavam águas meio salobras, e que foram durante algum tempo também de arrozais, responsáveis pelo sezonismo e suas mortes, tal como noutras várzeas mal drenadas da província, o que o povo reconhecia ao aconselhar que "quem o céu queira, vá primeiro a Aljezur e às várzeas de Quarteira".

No conjunto das fotos, gostaria ainda de ressaltar as que nos proporcionam imagens espectaculares dos caprichos do litoral, dos alcantilados da Costa Vicentina às arribas recortadas nas formações sedimentares do Barlavento e aos estuários sinuosos ao sabor das dinâmicas das restingas arenosas e mais ainda às áreas lagunares; as que evidenciam as áreas de agricultura renovada e intensiva, nomeadamente associada à "plasticultura"; ou as obras portuárias, os molhes de protecção das bacias de atracação interiores, cada vez menos ao serviço da pesca e do comércio e cada vez mais, ao serviço do recreio e do turismo de lazer, num redesenhar das margens; as que exprimem as novas formas de habitar, numa sociedade das mobilidades, do encurtar dos espaços e dos tempos, do apagar dos efeitos das fronteiras, em contextos de explosão primeiro dos voos 
charters e depois das low cost e de aumento considerável dos tempos livres e dos tempos de vida; os novos condomínios mais ou menos vigiados e fechados ao exterior; a renovação do velho casario rural disperso e isolado que fora abandonado pelas populações agrícolas em êxodo; ou a dispersão densa e ordenada de novas habitações unifamiliares, com mais ou menos qualidade, maior ou menor identificação com certas formas da arquitectura regional tradicional, muitas com piscina privada; as que evocam a continuidade dos ritmos sazonais de vida, sazonalidade do passado e do presente.

Nos campos, o trabalho era intenso de Maio a Outubro, com as ceifas, as debulhas, as regas das hortas e a apanha dos frutos secos. Nas praias, a animação, e até mesmo o povoamento, começava com a chegada dos cardumes, e com eles a das companhas das xávegas e armações de sardinha e de atum. O turismo balnear das elites regionais e do Baixo Alentejo, mais ou menos burguesas e fundiárias, apenas reforçava a animação das praias nos meses de Verão, dando lugar às famílias camponesas já no início do Outono, terminadas as colheitas pelo São Miguel. Pontualmente, camponeses algarvios, no sentido do Baixo Algarve, e montanheiros, vinham banhar-se nas águas salgadas do oceano, em busca de um pouco mais de saúde, num excursionismo terapêutico, ou numa migração de algumas semanas outonais em busca de um pouco de iodo e de repouso.

Os novos turismos, que simbolizamos com a construção, nos primeiros anos 60 do passado século, de hotéis de certa dimensão e prestígio, na Praia da Rocha, em Armação de Pêra, em Albufeira e em Monte Gordo, alguns claramente encastrados nas arribas, perpetuaram e reforçaram as velhas sazonalidades da animação das praias, onde o colorido dos barcos e das gentes da pesca, pescadores, armadores e negociantes, foi substituído pelo dos chapéus-de-sol e dos corpos de muitas e desvairadas gentes, de nacionalidades bastante mais diferenciadas do que as que giravam em torno das pescas e das conservas de peixe. Há neste livro excelentes fotografias das praias algarvias, com seus sectores de toldos e de chapéus-de-sol de todas as cores, bem juntinhos, criando por si só certas oportunidades de conhecimento e gerando novos tipos de vizinhança.

Mas os novos turismos também diluem as sazonalidades clássicas, porque são diversificadas as suas motivações e largas as suas margens de liberdade, mesmo se os calendários escolares e empresariais continuam a coarctar as opções e até mesmo as preferências dos casais com filhos jovens em idade escolar e que viajam com eles ou dos activos em certos sectores e empresas: resta todavia o turismo residencial, o turismo de golfe, os turismos cultural ou em busca de ambientes e paisagens amenos e diferentes, e até certos pequenos nichos de procuras mais ou menos exóticas, etc.

A diversificação dos modos de habitar e as dinâmicas das densidades do povoamento, não mais apenas em função do tradicional conceito de população residente, mantém muitos dos ritmos sazonais da vida regional do passado, mas tendem cada vez mais a esbatê-los, justamente quando se apagam os associados à agricultura de sequeiro por abandono quase total da mesma e à pesca tradicional ou de feição já industrial de espécies pelágicas como a sardinha, a cavala e o carapau, também ela concentrada em poucos portos e poucas empresas e deixando à margem muitos dos velhos aglomerados piscatórios, refugiados na pesca artesanal e cada vez mais dependentes do mercado turístico, directa e indirectamente... 
NOTÍCIAS 



\section{COLÓQUIO IBÉRICO DE GEOGRAFIA}

VIRGÍNIA HENRIQUES ${ }^{1}$

PATRÍCIA PEDRo-RÊGO ${ }^{1}$

O X Colóquio Ibérico de Geografia subordinado ao tema "A Geografia Ibérica no Contexto Europeu" decorreu na Universidade de Évora, entre 22 e 24 de Setembro de 2005.

Este encontro ibérico realiza-se desde 1979, de três em três anos, alternadamente em Espanha e Portugal, numa organização conjunta da Asociación de Geógrafos Españoles e da Associação Portuguesa de Geógrafos, constituindo o principal encontro de reflexão e debate dos temas mais relevantes da Geografia Peninsular.

A escolha do tema do X Colóquio Ibérico resultou dos novos desafios colocados às regiões de Portugal e Espanha face ao recente alargamento da União Europeia. A Comissão Organizadora, ciente da necessidade de reflexão nesta matéria por parte da comunidade geográfica ibérica, estruturou o Colóquio em cinco Eixos Temáticos:
A. Novas estratégias e reorganização territorial numa Europa alargada;
B. Desafios para a multifuncionalidade da paisagem;
C. As cidades ibéricas entre o marketing urbano e as estratégias de bem-estar;
D. A geografia física da Península Ibérica, novos contributos;
E. Análise espacial e modelação geográfica.

As sessões temáticas decorreram nos dias 22 e 23 de Setembro e foram intercaladas por conferências e mesas redondas. $\mathrm{O}$ dia 24 foi dedicado a duas visitas de estudo, uma ao Empreendimento de Alqueva e outra à Região Transfronteiriça. Todas as actividades foram coordenadas por especialistas de várias universidades e instituições.

O Colóquio contou com 294 participantes dos quais 226 de Portugal, 63 de Espanha, 2 do Japão, e 3 de outras nacionalidades (Alemanha, Holanda e México), pertencentes a diferentes instituições (quadro I).

$\mathrm{Na}$ abertura dos trabalhos do Colóquio participaram o Professor João Ferrão, Secretário de Estado do Ordenamento do Território e das Cidades, o Professor Diogo Figueiredo, Vice-Reitor da Universidade de Évora, o Professor Ricardo Mendez, Presidente da Asociación de Geógrafos Españoles, o Professor Mário Vale, Presidente da Associação

1 Membros da Comissão Organizadora do Colóquio. Departamento de Geociências da Universidade de Évora, Rua Romão Ramalho 59. Évora.7000-671. E-mail virginia@uevora.pt e patrego@uevora.pt 
Quadro I - Proveniência dos participantes

Table 1 - Participant affiliation

\begin{tabular}{lcr}
\hline \multicolumn{1}{c}{ Instituições } & $\begin{array}{c}\text { N. } \mathbf{0}^{\mathbf{0}} \text { de } \\
\text { participantes }\end{array}$ & $\mathbf{( \% )}$ \\
\hline Universidades & 192 & 65,3 \\
Escolas de Ensino Básico e Secundário & 21 & 7,1 \\
Institutos Politécnicos & 16 & 5,4 \\
Associações Profissionais de Geógrafos & 8 & 2,7 \\
Organismos do Ministério da Educação e outros & 4 & 1,4 \\
Comissões de Coordenação, Delegações Regionais e Câmaras Municipais & 4 & 1,4 \\
Associações de Municípios e Associações de Desenvolvimento Local & 3 & 0,1 \\
Empresas Privadas & 4 & 1,4 \\
Sem instituição declarada & 42 & 14,3 \\
\hline
\end{tabular}

Portuguesa de Geógrafos e a Professora Emília Sande Lemos, Presidente da Associação de Professores de Geografia.

Para além das comunicações, o Colóquio integrou duas conferências e duas mesas redondas. No primeiro dia de trabalhos a conferência inaugural foi proferida pela Professora Maria Dolores Garcia Ramón, da Universidade Autónoma de Barcelona, intitulada Viajeras Europeas en el Mundo Árabe: una Mirada desde la Geografia Postcolonial (Gertrude Bell 1868-1926). O segundo dia de trabalhos iniciou-se com a conferência da responsabilidade do Professor Willem Vos da Universidade de Wageningen (Holanda), intitulada The Uniqueness of Iberian Landscapes within Mediterranean Europe. Ao início da tarde realizou-se uma mesa redonda dedicada ao tema "A Geografia e o Planeamento do Território". Nesta mesa redonda foram intervenientes o Professor Oriol Nello i Colon da Generalitát de Catalunya e a Professora Margarida Pereira da Universidade Nova de Lisboa. Os trabalhos foram coordenados pela Professora Teresa Barata Salgueiro, da Universidade de Lisboa. Ao fim da tarde realizou-se a última mesa redonda subordinada ao tema "Jovens Geógrafos. Progressos Científicos e Perspectivas Profissionais", da responsabilidade dos Professores João Sarmento, da Universidade do Minho, e Florêncio Zoido, da Universidade de Sevilha, que moderou a Sessão. Nesta mesa redonda participaram ainda o Professor Sérgio Claudino, da Universidade de Lisboa, os Professores López Lara e Miranda Bonilla, da Universidade de Sevilha, e o Professor João Ramires Pimenta, da Universidade do Porto.

Durante o Colóquio foram apresentadas 108 comunicações distribuídas pelos vários eixos temáticos e seguidas de debate amplamente participado.

O eixo temático A. Novas estratégias e reorganização territorial numa Europa alargada contou com a coordenação científica dos Professores Joan Nogué, da Universidade de Girona, e José Alberto Rio Fernandes, da Universidade do Porto. O eixo foi estruturado de acordo com os seguintes temas: A ideia de Europa; A dimensão territorial da Europa alargada; Novas estratégias de desenvolvimento territorial. Nesta temática foram apresentadas 17 comunicações.

O eixo temático B. Desafios para a multifuncionalidade da paisagem teve orientação científica dos Professores Rafael Mata, da Universidade Autónoma de Madrid, e Teresa Pinto Correia, da Universidade de Évora. As linhas de trabalho para este tema privilegiaram: $\mathrm{O}$ conhecimento da diversidade paisagística e suas multifuncionalidades; As transformações das actividades produtivas, em particular nas áreas rurais; Os valores da paisagem na gestão das áreas periurbanas; Os valores da paisagem nas ini- 
ciativas e políticas de desenvolvimento territorial e turístico; A análise e avaliação das políticas públicas para a conservação, gestão e recuperação das múltiplas funções da paisagem; A participação pública nas iniciativas de ordenamento e gestão da paisagem. Neste eixo foram apresentadas 24 comunicações.

$\mathrm{O}$ eixo temático C. As cidades ibéricas entre o marketing urbano e as estratégias de bem-estar com coordenação científica a cargo dos Professores Victor Fernández Salinas, da Universidade de Sevilha, e Maria Lucinda Fonseca, da Universidade de Lisboa, reuniu comunicações em torno de três temas fundamentais: A cidade ibérica, realidades e transformações estruturais impostas, estimuladas ou entorpecidas pelo papel de Espanha e Portugal na nova ordem global; Natureza e cultura como definidoras da identidade urbana ibérica; Cidadãos nas cidades ibéricas? Nesta temática foram apresentadas 33 comunicações.

O eixo temático D. A geografia física da Península Ibérica - novos contributos, coordenado cientificamente pelos Professores Júlio Muñoz, da Universidade Complutense de Madrid, e Lúcio Cunha, da Universidade de Coimbra, centrou-se nos temas: Análise, balanço e valorização da produção científica recente dos centros de investigação geográfica de Portugal e Espanha (organização morfo-estrutural, geomorfologia, bioclimatologia, hidrologia e paisagens naturais); Novas perspectivas de estudo de algum dos componentes do meio ou enquadrados em linhas de investigação com ideias críticas sobre componentes físicos ou das paisagens da Península; Novas perspectivas de aplicação de conceitos, métodos e técnicas no campo da planificação dos territórios peninsulares (recursos naturais, riscos naturais e impactes ambientais). Nestes temas foram apresentadas 24 comunicações.

O eixo temático E. Análise espacial e modelação geográfica com coordenação científica dos Professores Emílio Chuvieco, da Universidade de Alcalá de Henares, e José Tenedório, da Universidade Nova de Lisboa, privilegiou a apresentação de trabalhos orientados pelos tópicos: Modelação e simulação de fenómenos e processos espaciais; Identificação e análise de estruturas espaço-temporais; Análise espacial e representação geográfica; Detecção remota e análise geográfica; Aplicações Internet. Neste eixo foram apresentadas 10 comunicações.

No último dia de trabalhos realizaram-se as duas visitas de estudo com cerca de 70 participantes. Uma ao Empreendimento de Alqueva, organizada pelos Professores José Manuel Simões, da Universidade de Lisboa, e Teresa Pinto Correia, da Universidade de Évora, apresentou o Empreendimento de Fins Múltiplos de Alqueva e as Unidades de Paisagem de Campos de Reguengos e de Albufeira do Alqueva. A outra visita, com destino à Região Transfronteiriça, foi organizada pelas Professoras Inmaculada Caravaca e Rocio Silva, da Universidade de Sevilha, Isabel Margarida André, da Universidade de Lisboa, e Patrícia Pedro-Rêgo, da Universidade de Évora. Esta visita intitulada De Serpa a Almonaster la Real-Culturas e Paisagens de Fronteira privilegiou quer as questões da instabilidade histórica desta fronteira terrestre e o papel aí assumido pelas elites locais, quer a diversidade natural e humana da sierra de Huelva no contexto da sierra Morena.

A importância do Colóquio ficou demonstrada pelo interesse suscitado ao longo dos trabalhos e comprovada pela qualidade e pelo número das comunicações, mesas redondas e conferências proferidas. Os resultados dos trabalhos foram editados num livro de resumos com 280 páginas e num pequeno guia de campo com 43 páginas. O texto integral das comunicações foi posteriormente editado em formato digital. 



\title{
XIV COLÓQUIO EUROPEU DE GEOGRAFIA TEÓRICA E QUANTITATIVA (ECTQG'05)
}

\author{
Paulo Morgado ${ }^{1}$ \\ JORGE ROCHA ${ }^{1}$
}

O Colóquio Europeu de Geografia Teórica e Quantitativa (ECTQG - European Colloquium of Theoretical and Quantitative Geography) é um evento mundial. Parece uma contradição, mas não é. O ECTQG permite, a investigadores europeus e de fora da Europa, a troca de experiências e conhecimentos sobre o que de mais inovador se tem feito no domínio da geografia neopositivista. Desde o primeiro colóquio, em 1978 em Estrasburgo, até ao último, de 2005, realizado em Tomar, muitas foram as temáticas abordadas que sublinham a corrente de estudo e investigação, duma Geografia aplicada, muito apoiada nas ciências exactas e de cálculo, mas sem esquecer a ligação às Humanidades, porque o sentido de servir a sociedade esteve sempre presente nas preocupações do geógrafo.

Realizado de dois em dois anos, normalmente em cidades pequenas, o ECTQG não é um evento exclusivo aos geógrafos; antes pelo contrário, incentiva-se o contributo e participação de todos aqueles que se interessam e ou praticam geografia(s). É comum o envolvimento de especialistas de domínios das engenharias (engenharia geográfica, engenharia civil, engenharia informática e das telecomunicações), economistas, matemáticos e físicos, entre outros, que integram nos seus estudos e trabalhos de investigação a dimensão espacial e as relações Homem e Meio. Normalmente, o evento perdura por um período de 5 dias, no decurso dos quais se expõem os resultados das investigações feitas e se redefinem as fronteiras do conhecimento geográfico.

O XIV ECTQG realizou-se no mês de Setembro de 2005, e foi, até à data, o de maior sucesso. Para que se possa compreender as razões a que se deveu este sucesso, tentamos aqui relatar, de uma forma sintética e objectiva, o que se passou, do que tratou, e qual a sua importância para a Geografia. Comecemos pelos responsáveis. O XIV ECTQG foi organizado pelo e-Geo - Centro de Estudos de Geografia e Planeamento Regional, da Faculdade de Ciências Sociais e Humanas da Universidade Nova de Lisboa, e por uma metódica equipa que, sob a coordenação do Professor Doutor José António Tenedório (Presidente do e-Geo) e do Professor Doutor Rui Pedro Julião (Vice-Presidente do eGeo), permitiu que este ECTQG desse, mais uma vez, mostras do importante contributo da geografia quantitativa para a compreensão dos fenómenos complexos que caracterizam o território, bem como para o desenvolvimento dos sistemas de apoio à decisão.

1 Investigadores do Centro de Estudos Geográficos e Assistentes do Departamento de Geografia da Faculdade de Letras da Universidade de Lisboa.Email: pms@ceg.ul.pt e jrocha@ceg.ul.pt 
O XIV ECTQG, em números, significa o envolvimento directo de 221 autores, 132 participantes oriundos de vários países (França, Itália, Holanda, Inglaterra, Austria, Bélgica, Suécia, Escócia, Grécia, Japão, China, Israel, Alemanha, Dinamarca, Canadá, Bélgica, Polónia, República Checa e China), 99 artigos distribuídos por 2 sessões paralelas e 11 temas, dos quais importa explicar a essência.

No caso dos autómatos celulares e sistemas multiagentes, expressou-se a preocupação na análise multiescala e multitempo, de fenómenos como a evolução do uso do solo, urbanização, desenvolvimento sustentável e modelação de questões sociais.

$\mathrm{Na}$ temática da análise fractal, obtivemos ecos do rejuvenescimento do estudo da paisagem pelos geógrafos, mas também na análise da morfologia urbana, e da forma como a geometria fractal pode explicar a estrutura urbana e socio-económica.

Sobre desenvolvimento regional e urbano, ficaram os apontamentos da curiosidade pelo estudo da geografia dos modelos, agora renovada sob o epíteto de geomodelação, apoiada na simulação permitida pela computação (geocomputação, geosimulação, ...), no estudo de redes (geografia das redes, retomada dos estudos de Peter Hagget, de 1969, e que tão bem se aplicam hoje à geografia dos transportes e das telecomunicações) e de clusters tecnológicos e de inovação.

A sessão dos Sistemas de Informação Geográfica foi marcada pela temática do ambiente, com a preocupação evidente ao nível da gestão dos recursos naturais, riscos e da poluição, assim como a temática da análise espacial, com artigos a testemunharem quer uma abordagem mais clássica e aplicativa, sobretudo em estruturas de dados raster, mas também no desenvolvimento de novos métodos e algoritmos, e na interação com a estatística multivariada.

A temática da detecção remota também foi abordada. Com pergaminhos nos métodos de trabalho dos geógrafos e nos trabalhos de Geografia, a detecção remota, pela quantidade e qualidade dos artigos submetidos, mereceu uma sessão individual, em que foram feitas comunicações de dois tipos: umas de âmbito mais teórico, sobre a cientificidade da detecção remota e os processos evolutivos que tem sofrido ao longo dos tempos, e outra mais técnica e metodológica, em que se fez apelo à sua capacidade de monitorização dos sistemas. Neste âmbito, as exposições foram sobre a vantagem da aplicação da classificação e processamento de imagens ao estudo de diversos fenómenos (mudanças climáticas, incêndios florestais, dinâmica do litoral, evolução do uso e ocupação do solo, ciclos vegetativos, etc.).

Por último, também a merecer destaque, uma sessão dedicada à análise estatística, modelos matemáticos e topologia. Aqui a discussão desenvolveu-se sobre o formalismo em geografia quantitativa, a procura de padrões espaciais, teoria da geoestatística, dos modelos por detrás da Lei de Zip. A análise espacial e a complexidade foram dois dos principais temas discutidos, em que foram apresentadas virtudes e defeitos de métodos como a lógica fuzzy, teoria de bayes, análise multivariada, redes neuronais supervisionadas e não supervisionadas (self organizing maps), para determinar novas tipologias e constelações espaciais, em sistemas multi-agentes, de comportamento dinâmico, como é o caso do espaço urbano.

Dada a importância que este evento científico tem para a Geografia, o Centro de Estudos Geográficos da Universidade de Lisboa não podia deixar de estar presente. Para além de ter estado representado oficialmente na sessão de abertura, a convite da organização, contribuiu com a apresentação de alguns resultados dos trabalhos dos seus investigadores, sobre o uso de métodos de análise espacial, com recurso aos autómatos celulares, redes neuronais e análise estatística multivariada na determinação de 
padrões espaciais de competitividade e na simulação prospectiva de evolução do uso. Como nota final, quem coordena e gere este projecto. Desde o princípio (década de 70) coordenado por Denise Pumain (actualmente Professora da Universidade Paris I; directora do laboratório Geografia-cidades e directora científica da revista electrónica cybergeo: http://www.cybergeo.presse.fr/) e de sempre apadrinhado por Manfred Fisher (actualmente, Professor e Director do Departamento de Geografia Económica e Geoinformática da Universidade de Economia e Administração de Viena; fundador e Editor-chefe do Journal of Geographical Systems, Geographical Systems, Analysis, Theory and Decision, Springer), o ECTQG tem sabido definir o seu caminho e, mais importante ainda, o ECTQG e seus colaboradores têm mantido fidelidade científica.

Pela sua importância, que aqui se tentou relatar, no domínio mais circunspecto da geografia aplicada, ou mais lato, sobre o aprofundamento teórico dos estudos geográficos, aconselhamos a todos os geógrafos e àqueles que se interessam pela Geografia, a estarem atentos e participarem no próximo ECTQG (XV ECTQG'07), organizado pelo Instituto de Geografia - Faculdade de Geociências e Ambiente da Universidade de Lausanne, em Montreux, na Suiça, de 7 a 11 de Setembro de 2007. Para mais informações pode consultar-se o site http://www2.unil.ch/ectqg07/index.html 



\title{
O CLIMA COMO RECURSO NA CONFERÊNCIA TÉCNICA DA ORGANIZAÇÃO METEOROLÓGICA MUNDIAL
}

\author{
MARIA Jõ̃o AlCOFORADO ${ }^{1}$
}

O clima afecta diversos aspectos das actividades humanas e pode ser considerado tanto um factor de risco como um recurso. A variabilidade do clima e as variações a longo prazo têm grande influência na disponibilidade de recursos naturais e nas sociedades humanas. Neste contexto, o clima pode ser visto como um dos mais importantes recursos naturais, que, se bem compreendido e adequadamente gerido, poderá contribuir para o desenvolvimento sustentável. O conhecimento do sistema climático tem evoluído muito rapidamente, sobretudo nas últimas décadas, devido à tomada de conciência da sua importância e a rápidos progressos tecnológicos na monitorização e na modelação do clima. Os resultados dos estudos permitirão aos diferentes sectores da sociedade lidar com os riscos relacionados com episódios climáticos extremos e beneficiar dos recursos climáticos.

Para discutir e partilhar ideias, experiências e conhecimentos, teve lugar, a 1 e 2 de Novembro de 2005, em Pequim, a Conferência Técnica sobre o tema 'Clima como Recurso', organizada pela Organização Meteorológica Mundial (OMM). Participaram estudiosos do clima, a maior parte proveniente de Institutos de Meteorologia, e também 'utilizadores', oriundos de 71 países.

Na sessão de abertura, o Secretário-Geral da OMM, M. Jarraud, salientou que o clima constitui um recurso apreciável, a preservar para as gerações vindouras. Ressaltou os dois grandes temas em discussão na conferência: a) Salientar as potencialidades da informação climática na exploração sustentável dos recursos naturais, susceptíveis de desempenhar um papel-chave na vida e no bem-estar das sociedades e b) Discutir as formas mais eficazes de transmissão da informação dos Institutos de Meteorologia e de Hidrologia para os utentes.

As conferências foram agrupadas em quatro blocos (dois por dia): a importância do clima no desenvolvimento sustentável, os problemas relacionados com a água, a dependência climática da produção de alimentos e a influência do clima no conforto, na saúde e no planeamento urbano.

1 Professora Catedrática da Universidade de Lisboa, Investigadora do Centro de Estudos Geográficos. E-mail: mjalc@fl.ul.pt 


\section{PRIMEIRA SESSÃO: 'CLIMA, DESENVOLVIMENTO SUSTENTÁVEL E ECONOMIA'2}

O presidente da Comissão de Climatologia da OMM, Y. Boodhoo, orador da conferência introdutória, frisou a importância do clima em diferentes sectores socio-económicos, tais como agricultura e pecuária, gestão da água, assim como no sector energético e no turismo. Salientou que um dos objectivos desta conferência era divulgar os 'serviços climáticos', identificando os seus potenciais utilizadores e dar a conhecer medidas apropriadas às diversas actividades, tendo em conta as previsões de variação do clima a médio prazo. No caso da saúde humana, dado como exemplo, se as previsões espacializadas das vagas de calor forem atempadamente conhecidas, de modo a desencadear sistemas de alerta, poder-se-ão esperar resultados positivos na diminuição quer da morbilidade e mortalidade associadas a esses episódios meteorológicos extremos, quer de prejuízos económicos. Por outro lado, os conhecimentos climáticos podem ser utilizados de modo inteligente para reduzir o consumo de energia. O orador reconheceu que a indústria do turismo é hoje uma das mais importantes e que depende, em larga medida, do clima. Afirmou igualmente que, com a informação climática adequada, se poderão atingir objectivos de qualidade, segurança e conforto nas cidades, dando especial atenção ao planeamento e desenho urbano. Se a génese climática de certos desastres naturais é indiscutível, a relação entre o aumento da sua frequência e as variações climáticas globais é ainda um problema em discussão.

Os três oradores, que se seguiram nesta sessão, falaram de recursos climáticos diferentes, mas com importantes consequências económicas: F. Frangialli, secretáriogeral da Organização Mundial do Turismo (OMT), Panmao Zhai ${ }^{3}$, Presidente da China Meteorological Administration (CMA) e Hatwig Dobesch, do Instituto de Meteorologia e Geodinâmica da Áustria. O primeiro considerou que o clima é um recurso-chave para todas as formas de turismo, que pressupõem actividades ao ar livre; noutras formas de turismo, o clima terá uma influencia indirecta - por exemplo na disponibilidade e qualidade da água doce. A OMM e a OMT deverão colaborar de modo a que o turismo continue a gerar benefícios socio-económicos a diversos países e proporcione experiências de qualidade aos turistas. Referiu estações de desportos de Inverno, em que a variabilidade do clima (neste caso a diminuição da queda de neve) gerou já um grave problema: as empresas não estão a investir abaixo de $2000 \mathrm{~m}$ de altitude nos Alpes. Por outro lado, a produção de neve artificial também está dependente das reservas de água. A partir deste e de outros exemplos, mostrou que a OMT considera muito importante a inclusão de informação climática e das previsões a médio e longo prazo nos projectos de desenvolvimento futuro, tal como foi focado na "Primeira Conferência sobre Variação do Clima e Turismo", que teve lugar em Djerba (Tunísia), em 2003.

Os outros dois oradores centraram-se nas energias alternativas, curiosamente quase exclusivamente na produção de energia eólica. Esta não tem custos de importação, não está dependente do aumento do preço dos combustíveis, não emite gases de estufa e é um recurso renovável. No caso da China, a produção de energia eólica aumentou de $20 \mathrm{MW}$ (em 1992) para $200 \mathrm{MW}$ em 2004; pretendem atingir-se $20 \mathrm{GW}$

2 Apenas serão contempladas as conferências que constam de um CD "Climate as Resource", distribuído no final do colóquio.

3 Refere-se apenas o orador, mesmo das conferências preparadas em colaboração. 
até 2020. Com o exemplo da Áustria, foram enumerados factores de exclusão para a localização de geradores eólicos e abordado o ponto de vista dos utilizadores e do público em geral, que concorda com a utilização deste tipo de energia alternativa, desde que não seja na sua propriedade. A esse propósito, referiu-se o síndroma NIMBY (Not In My BackYard).

\section{SEGUNDA SESSÃO: 'O CLIMA E A ÁGUA'}

A Conferência inicial foi proferida pelo japonês K. Takeuchi, que evocou a necessidade de fornecer cada vez mais informação climatológica e hidrológica à sociedade civil que, segundo ele, terá de aprender a tomar as decisões apropriadas para se proteger dos impactes dos acontecimentos meteorológicos extremos, tais como cheias e secas. Obviamente, a importância da informação climática aumenta à medida que cresce a vulnerabilidade das sociedades em relação aos extremos climáticos. Vindo de Nairobi (Climate Prediction and Application Centre), Laban A. Ogallo interrogou-se se os Institutos Meteorológicos se apercebem das necessidades do público; como aspecto positivo, referiu forums, que têm lugar desde 1998, agregando cientistas, decisores e utentes e que têm dado uma enorme contribuição para a previsão estacional, para a disseminação da informação em África e para a gestão dos riscos naturais. Também contribuem para intensificar ou iniciar o diálogo entre os estudiosos do clima e uma faixa muito larga de utilizadores. Continuando sobre o mesmo tema, Won-Tae Yun, da Korea Meteorological Administration deteve-se sobre dois principais problemas: a fragilidade de muitos modelos de previsão a longo prazo e a dificuldade da comunicação dos resultados à população, por vezes pouco instruída. J.H.Y. Katima resumiu as conclusões do relatório do IPCC de 2001, pouco relevantes, uma vez que se espera um novo relatório no início de 2007, e M.N. Ward (International Research Institute for Climate Prediction, EUA) falou sobre os serviços climáticos necessários para a gestão dos recursos em água.

\section{TERCEIRA SESSÃO: 'CLIMA E PRODUÇÃO DE ALIMENTOS'.}

A terceira sessão foi dedicada ao tema 'Clima e produção de alimentos'. Roger Stone, da Universidade de Qeensland, proferiu a conferência introdutória, tendo falado sobre 'Informação climática, previsão climática e produção de alimentos'. Iniciou a intervenção pela apresentação da variabilidade da precipitação em diversas áreas do globo, suas causas e consequências na agricultura. Mostrou, a partir de diversos exemplos, como a transmissão às populações de previsões climáticas a médio prazo e a adaptação das técnicas de cultivo podem ter resultados positivos. Fez notar que as previsões a diversas escalas temporais da variabilidade ou da variação climática poderão necessitar de medidas específicas: por exemplo, uma variabilidade da precipitação com uma frequência esperada de alguns meses terá como consequência a adaptação da data da sementeira, ao passo que uma variação climática levará à modificação do uso do solo, do tipo de culturas agrícolas, etc.

Nas sessões subsequentes, estes princípios foram ilustrados com exemplos do continente africano (por F. Karanja, Universidade de Nairobi), da África sub-sahariana (L.S. Unganai, Zimbabwe), da produção de açúcar das ilhas Fidji (J. Gawater, Sugar 
Cane Research Centre, Fidji), da Tailândia (N. Ouprasitwong, Departamento de Meteorologia tailandês), do Malawi (D. R. Kamdonyo, Serviços Meteorológicos daquele país, que referiu sobretudo o problema da gestão das secas) e da China (Chunqiang Li; Instituto de Meteorologia da província Hebei, China e Lu Houquan, do Chinese Meteorological Administration de Pequim). A comunicação de N. Ward, vindo de The Earth Institute at Columbia University, com o título 'Futuros serviços climáticos para aproveitar oportunidades e vencer desafios na agricultura' foi baseada numa reflexão sobre a gestão dos recursos e riscos para as práticas agrícolas e sobre o modo de fundir os conhecimentos ancestrais das populações com o manancial de informação climática e as previsões a médio prazo agora disponíveis.

\section{QUARTA SESSÃO: 'INFLUÊNCIA DO CLIMA NO CONFORTO, NA SAÚDE E NO PLANEAMENTO URBANO’.}

No início desta sessão, Nina. V. Kobysheva, do Observatório Geofísico de S. Petersburgo, referiu que o sucesso da climatologia aplicada depende da precisão da estimação dos recursos climáticos e fez uma súmula dos diferentes campos de aplicação dos conhecimentos climáticos. Retomou alguns tópicos já focados e referiu-se a outros temas que seriam tratados em mais pormenor nesta sessão: o clima como risco e recurso para a saúde humana e o planeamento urbano, a diversas escalas. Apresentou uma metodologia de construção de 'índices de recursos climáticos' aplicados à Rússia. Gerd Jendritzky (Serviços Meteorológicos da Alemanha) falou da potencialidade dos serviços climáticos aplicados ao sector da saúde. Referiu problemas devidos a stress térmico, radiação ultra-violeta, pólens e poluição do ar, doenças transmitidas por insectos, pela água ou pela alimentação e devidas a episódios climáticos extremos e sua variabilidade e variação temporal. Na segunda parte da sua intervenção, além de referir a importância das previsões meteorológicas e das suas consequências na população, fez a transição para as conferências subsequentes, indicando as modificações necessárias em termos de planeamento urbano e arquitectura, para reduzir o stress térmico no exterior e interior dos edifícios. Em seguida, eu própria apresentei um exemplo dos passos a seguir, desde a utilização da informação climática até à enumeração de orientações climáticas para o ordenamento urbano (na escala mesoclimática), com o objectivo de aproximação à 'cidade meteorologicamente utópica', através de selecção de estratégias adequadas. Foram dados exemplos de Lisboa. Finalmente, Xiaoyi Fang (do Beijing Meteorological Bureau) falou também das relações entre clima urbano e ordenamento a diversas escalas, dando exemplos de cidades chinesas. No caso de Pequim, foi apresentada a cidade, no seu conjunto, e também o parque olímpico, em construção, com simulações na escala microclimática.

É de notar que, na conferência sobre 'Recursos', foram muito frequentes as referências aos riscos que lhes estão associados, sobretudo no caso da gestão da água, da agricultura e da influência do tempo e do clima na saúde e em certas actividades humanas (como os seguros). O tema das variações climáticas esteve também sempre presente nas diversas discussões. Foram numerosas as sugestões para a intensificação do diálogo com as diversas comunidades de utilizadores. As principais conclusões desta conferência foram o ponto de partida de numerosas discussões da 14 . $^{\text {a }}$ reunião da Comissão de Climatologia da OMM, que se lhe seguiu, durante uma semana. 


\title{
O XVII SIMPÓSIO DE DIDÁCTICA DAS CIÊNCIAS SOCIAIS (ANTEQUERA, 2006)
}

\author{
SÉrgio Claudino ${ }^{1}$
}

De 4 a 7 de Abril de 2006, decorreu em Antequera (Espanha), o XVII Simpósio de Didáctica das Ciências Sociais, organizado pela Asociación Universitaria del Profesorado de las Ciencias Sociales (AUPCS) e que teve por tema A Didáctica das Ciências Sociais perante o Desafio Europeu: Formar para Investigar, Investigar para Formar em Didáctica das Ciências Sociais.

Aquela Associação conta com 140 membros, na sua quase totalidade espanhóis, que integram, maioritariamente, os departamentos de Didáctica das Ciências Sociais das numerosas universidades espanholas. Foram criados com a departamentalização das mesmas universidades determinada no começo dos anos 80 e a extinção das Escolas Universitárias de Formação de Professores do Ensino Básico (antes, Escolas Normais do Magistério) e das Faculdades de Pedagogia, onde se desenvolvia a formação de professores do Ensino Primário que, em Espanha, se estende do $1 .^{\circ}$ ao $6 .^{\circ}$ ano de escolaridade. Alguns dos professores das instituições desaparecidas foram integrados em departamentos universitários das respectivas especialidades científicas (Geografia, História...), mas a maioria transitou para os departamentos de Didáctica das Ciências Sociais ou de outras especialidades, conforme a sua formação. Muitos são antigos professores do Ensino Primário, entretanto licenciados em Geografia, História e áreas afins (a licenciatura é, presentemente, obrigatória para os docentes dos departamentos de Didáctica das Ciências Sociais) ou que, eventualmente, se doutoraram. A divisão entre departamentos universitários científicos específicos e aqueles ligados à formação de docentes traduz-se numa clara separação entre os respectivos docentes e projectos de formação. Os departamentos de Didáctica das Ciências Sociais têm um reduzido número de professores catedráticos, o que lhes reduz a influência nas respectivas universidades. A AUPCS encontra-se, entretanto, associada à publicação de Enseñanza de las Ciências Sociales - Revista de investigación, editada pelos Institutos de Ciências da Educação da Universidade Autónoma de Barcelona e da Universidade de Barcelona, de periodicidade anual, com seis números publicados e distribuída pelos respectivos associados.

O tema do Simpósio dificilmente poderia ser mais pertinente: perante a convergência europeia da formação de professores, ditada pelo Processo de Bolonha, centra-se a

1 Investigador do Centro de Estudos Geográficos e docente do Departamento de Geografia da Faculdade de Letras da Universidade de Lisboa. E-mail: sc@ceg.ul.pt 
atenção na investigação educacional, como finalidade tanto da formação como dos próprios formadores. Até 2011, quando se encontrarem formados os primeiros professores segundo os novos currículos, estarão reformados cerca de um terço dos actuais docentes do Ensino Primário espanhol, pelo que muitos dos futuros docentes se vão preparar segundo os novos planos de estudos. Esta realidade aplica-se a outros países europeus, como a França, onde se prevê que, nos próximos dez anos, se reformem metade dos professores do ensino não superior.

Em Espanha, os cursos de formação de professores do Ensino Primário têm a duração de três anos lectivos, dos quais cerca de três meses são de estágio nas escolas. A formação inicial de professores do Ensino Secundário (também obrigatório e com a duração de quatro anos, dos 12 aos 16 anos) e do Bacharelato (formalmente integrado no grau anterior, de frequência opcional e com a duração de dois anos, para jovens de 17-18 anos) é ainda mais escassa: depois de licenciados nas áreas científicas específicas, os futuros docentes frequentam os Institutos de Ciências da Educação. Aí obtêm o Certificado de Aptidão Pedagógica (CAP), após concluírem um curso que, há poucos anos, tinha a duração máxima de três meses mas, presentemente, se alonga por quase um ano escolar e em que o contacto directo com as escolas é, necessariamente, reduzido. Talvez também pela pouca confiança que esta preparação confere, o ingresso na docência do ensino público é feito mediante aprovação num exame nacional da responsabilidade das autoridades centrais - o que sucede, igualmente, em França.

Participaram no Simpósio cerca de setenta professores, na sua quase totalidade espanhóis; entre os estrangeiros, contaram-se conferencistas franceses e docentes da América do Sul hispânica. Se nos recordarmos das várias centenas de professores que, em toda a Espanha, trabalham nos departamentos de Ciências Sociais, podemos falar de uma limitada adesão.

O Simpósio decorreu num hotel, equipamento cada vez mais mobilizado para este tipo de eventos. Ganha-se na comodidade de concentrar num único espaço o alojamento e os trabalhos das reuniões científicas, mas perde-se no contacto com as próprias instituições de formação de professores, onde este evento poderia igualmente decorrer. Aos participantes no Simpósio foi entregue o livro de Actas, de 449 páginas, de grande utilidade para a mobilização da quase totalidade das apresentações.

Ao encontro da própria natureza dos simpósios, reuniões mais dominadas pela apresentação das perspectivas de especialistas do que pelo debate, os trabalhos foram marcados por dez conferências, em que se abordaram $i$ ) a formação inicial e investigação docente em França (três conferências), ii) propostas de currículos de formação inicial e de projectos de investigação (quatro conferências), iii) projectos de formação docente inicial presentemente a ser desenvolvidas no Ministério de Educação espanhol (duas conferências) e, por fim, iv) o valor formativo da História, numa conferência de carácter mais disciplinar. As conferências foram interessantes, mas algumas foram prejudicadas por uma deficiente preparação; teria sido mais enriquecedor se os participantes estrangeiros proviessem de países diversos, à semelhança do que sucedeu em simpósios anteriores.

Segundo as actas e a informação recolhida localmente, foram apresentadas vinte e nove comunicações, várias delas colectivas, num total de cinquenta comunicantes. Foi-lhes reservada apenas uma parte da manhã do segundo dia de trabalhos, em três sessões paralelas, o que se traduziu numa apresentação e discussão apressadas.

Os três primeiros dias de trabalhos distribuíram-se por outros tantos blocos: Investigar para formar, Formar para Investigar e A Formação de Professores de Ciências Sociais perante a Convergência Europeia. 
Os participantes franceses deram conta do difícil estatuto dos Institutos Universitários de Formação de Professores (IUFM): surgidos em 1990, pela conversão das Escolas Normais, foram integrados em 2001 nas universidades, onde têm um carácter periférico. Os IUFM são obrigados a negociar a formação inicial com um Ministério da Educação que lhes retirou a formação contínua de professores e assume, agora, uma crescente tutela na formação inicial, a que terá menor sensibilidade - sendo certo que, de há muito, o ingresso na docência é controlado através dos exames nacionais.

Os especialistas franceses queixam-se da diminuta investigação sobre as práticas escolares e de, em qualquer caso, os resultados da mesma não chegar à generalidade dos professores. As suas práticas permanecem praticamente inalteradas ao longo de anos; são marcadas positivamente pela consulta, pelos alunos, de documentação (que pretende substituir a realidade) num activismo que não esconde o facto de os alunos serem solicitados apenas para tarefas elementares, girando as actividades escolares em torno da figura do professor. O cepticismo instalado sobre a mudança das práticas docentes leva a que seja pouco provável a implementação de currículos organizados por competências - como já sucede no minoritário Ensino Secundário Profissional, mas sem reflexos na actividade escolar.

Os formadores franceses propõem uma forte aposta na investigação descritiva e interpretativa das práticas escolares, sobre as quais há um limitado conhecimento. Relativamente ao modelo de profissionalização inicial, pretende-se salvaguardar a sua qualidade; os futuros docentes de História e Geografia asseguram, no quinto e último ano, a docência de uma turma ao longo do ano lectivo, numa escola, sob a orientação de um professor orientador, elaborando um relatório de registo e reflexão sobre as suas práticas. O Ministério da Educação francês tem pretendido que os estagiários tenham maior envolvimento docente nas escolas, o que tornaria mais barata a sua formação inicial, mas os responsáveis dos IUFM têm-se-lhe oposto, por considerarem que tal prejudicaria o espaço de reflexão teórica. Nos próximos dez anos, prevê-se a reforma de mais de metade dos professores franceses. O Processo de Bolonha foi pouco evocado pelos representantes franceses, aparentemente mais preocupados com o difícil estatuto dos IUFM e o reduzido eco das suas propostas.

As conferências proferidas por responsáveis do Ministério da Educação espanhola foram escutadas com muita atenção e os participantes aproveitaram para fazerem sentir àqueles as suas preocupações. Em Espanha, prevê-se uma formação de professores do Ensino Primário de quatro anos (em dois ciclos, de três e um ano), num total de 240 European Credit Transfer System (ECTS), 180 de formação académica e 60 de orientação profissional. O governo determinará dois terços destes créditos, com o que assume uma clara liderança dos próprios currículos de formação inicial. $\mathrm{Na}$ formação dos docentes para o Ensino Infantil e Primário, desaparecem as especializações, substituídas pelas menções (ex.: música, biblioteca escolar...), com o que se pretenderá acentuar o carácter generalista da formação. A orientação profissional compreende cinco domínios de formação, entre eles o trabalho nas escolas, que hoje se desenvolve em cerca de três meses e que, assim, continuará a ter uma expressão secundária.

$\mathrm{Na}$ formação de professores do Ensino Secundário, prevê-se a criação de um mestrado do Ensino Secundário, com 60 créditos, repartidos por cinco módulos, entre eles os de formação disciplinar, psicológica e prática (estágio). Terá a duração de cerca de um ano escolar e a ele poderão aceder diplomados em cursos de quatro anos. Assim, a formação inicial docente durará perto de cinco anos, num modelo que acaba por ser algo semelhante ao actual, até no facto de se concentrar num único ano a preparação 
pedagógico-didáctica para a docência, com desvalorização do trabalho nas escolas. Os titulares de mestrado podem, depois, candidatar-se a doutoramento. Foram reveladas preocupações com a excessiva especialização universitária espanhola, que poderá não se repercutir na formação universitária.

Extinguem-se, assim, os CAP e prevê-se que o novo mestrado entre em vigor em funcionamento em 2007/08. Contudo, não é claro que se venha a assistir ao desaparecimento dos Institutos de Ciências da Educação, que presentemente se encontram apostados na formação pedagógico-didáctica de docentes universitários.

Durante o Simpósio, foram praticamente nulas as preocupações com o facto de a formação dos futuros professores espanhóis continuar a desvalorizar o trabalho nas escolas básicas, ao encontro do que a investigação educacional crescentemente recomenda. Por outro lado, o Processo de Bolonha é encarado dominantemente como uma alteração do plano curricular, de âmbito europeu, desvalorizando-se as preocupações metodológicas e de objectivos formativos que lhes estão associados - o que foi igualmente patente nas intervenções dos participantes franceses. Pelo contrário, existiu uma grande preocupação e, mesmo, tensão entre os participantes espanhóis: receia-se que os mais poderosos departamentos universitários disciplinares, perante a redução do número de alunos e a flexibilização de entidades formadoras introduzidas pelo Processo de Bolonha, pretendam assumir, agora, uma formação inicial de professores de que sempre andaram arredados. Por outro lado, no conjunto das intervenções dos participantes espanhóis, foi pouco o trabalho de investigação sobre a formação de professores divulgado, tendo este surgido, sobretudo, por parte dos participantes das universidades de Huelva e de Sevilha.

Esta reunião contou com um amplo e bem sucedido programa social, com destaque para as visitas à vizinha cidade de Málaga, no segundo dia do Simpósio, e a Ronda, no último dia.

Em Portugal, não se verificam os confrontos institucionais que atravessam as universidades espanhola e francesa. Resta verificar se a formação inicial de professores portuguesa vai manter as preocupações de qualidade que a têm marcado ou caminhará em direcção aos modelos de uma formação pouco dispendiosa e em que os próprios governos não confiam, como sucede em Espanha e em França - e, infelizmente, todos os indícios apontam nesse sentido. Por outro lado, talvez motivada por preocupações economicistas, parece claro que se assiste a uma crescente intervenção de governos europeus na formação inicial de professores dos ensinos Básico e Secundário, com diminuição da autonomia das instituições de Ensino Superior responsáveis.

Por fim, a dificuldade em mudar as práticas escolares parece constituir um denominador comum entre países - a demonstrar, uma vez mais, que as mesmas não se reformam por decretos, questionando responsáveis governamentais e formadores de professores. 


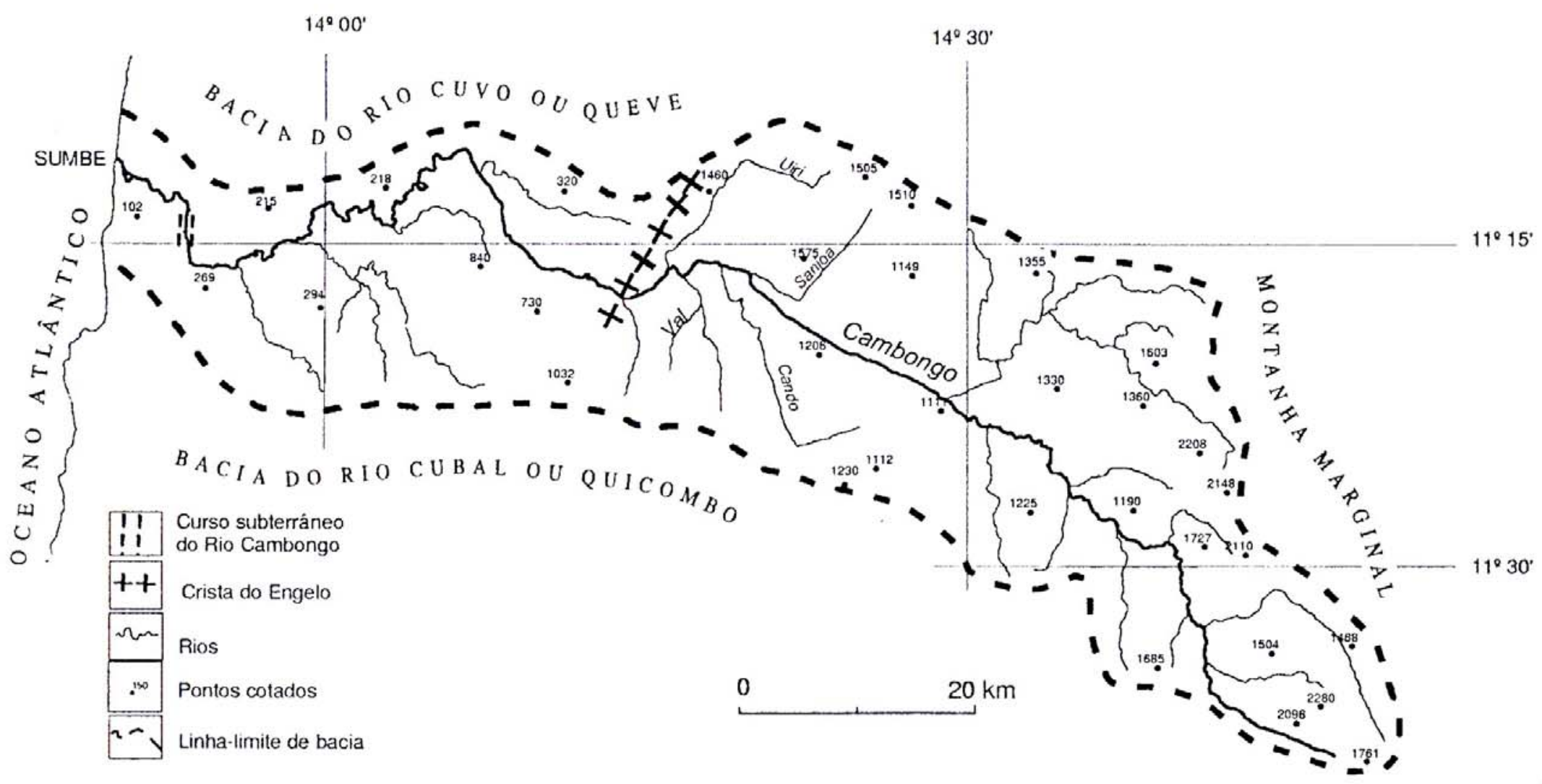

Fig. 1 - A bacia do rio Cambongo-Negunza entre as dos rios Cuvo ou Queve e Cubal ou Quicombo, e a Montanha Marginal 


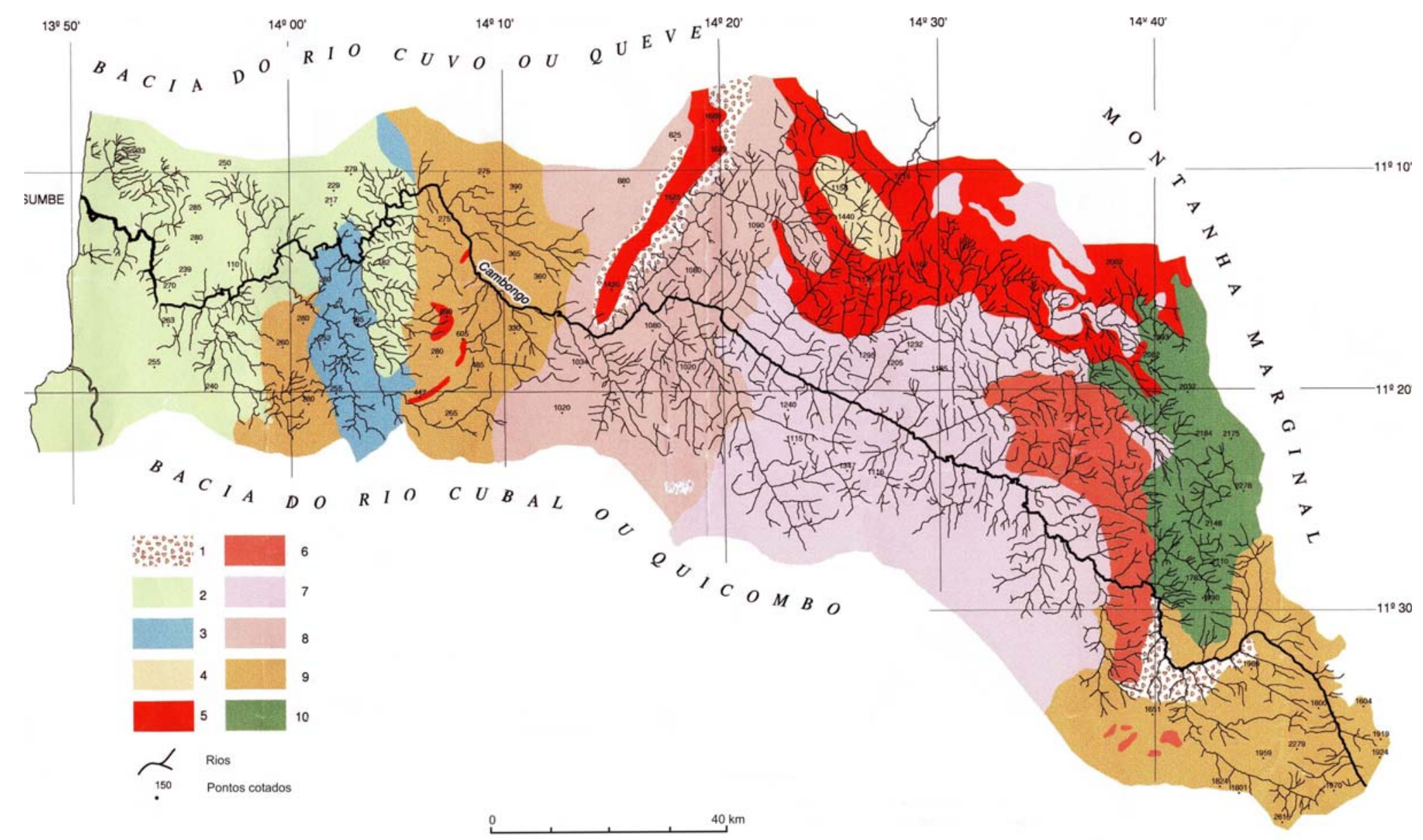

1 - Escombrciras e terraços; 2 - Orla Sedimentar, Complexo Meso-Antropozóico; 3 - Manto basáltico; 4 - Metagrauvaques; 5 -Metaquartzitos ; 6 - Quartzitos granitizados;

7 - Complexo granítico-granodiorítico, biotiticos porfirbides; 8 - Complexo granítico-granodiorítico-gnáissico; 9 - Migmatitos; 10 - Pórfiros granitóides, em geral recristalizados.

Fig. 2 - Esboço geológico da bacia Cambongo-Negunza a partir da cartografia existente 


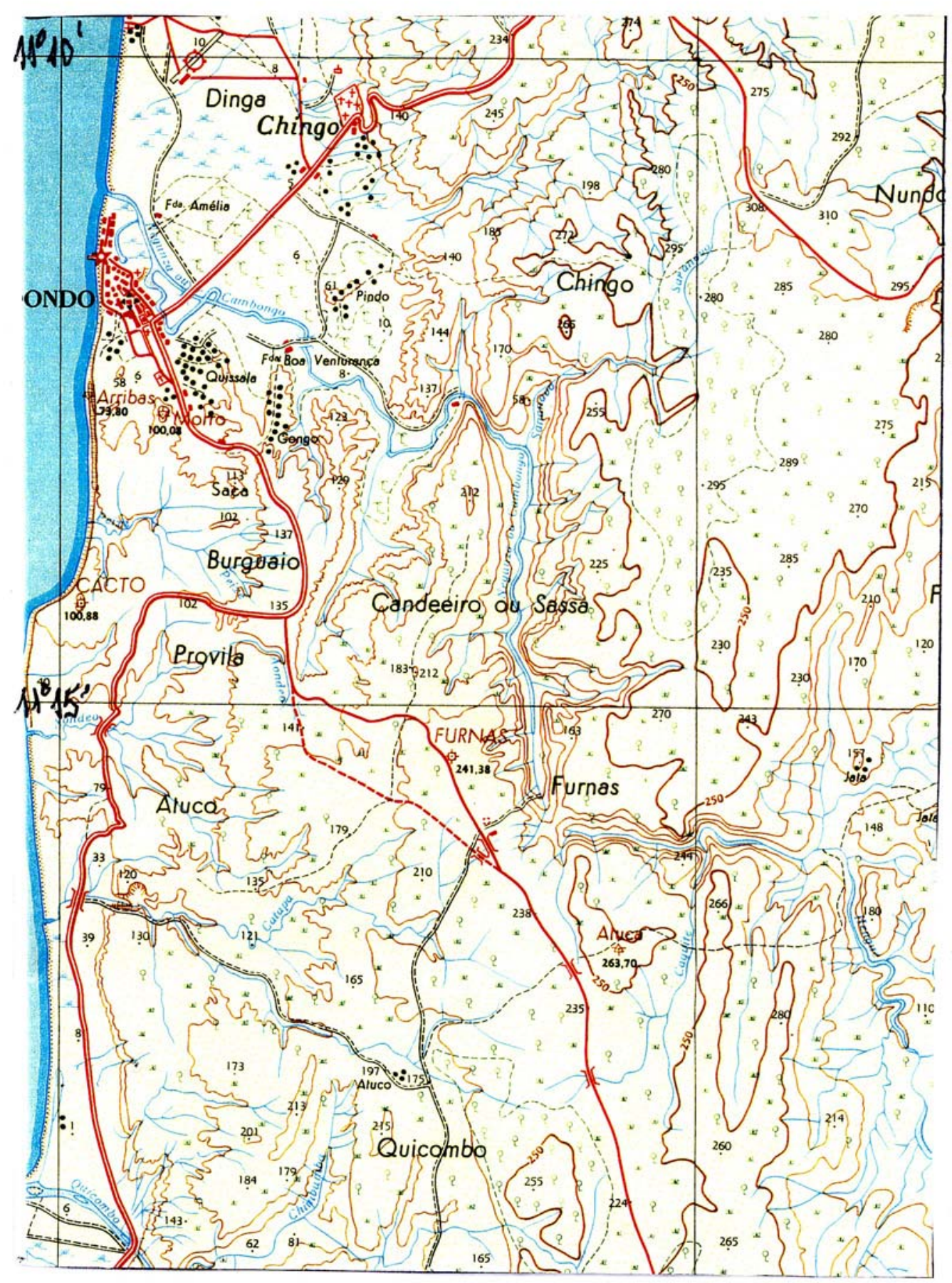

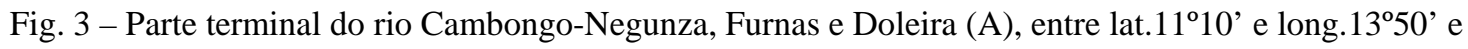
$13^{\circ} 55,5^{\prime}$, na escala 1:100 000 


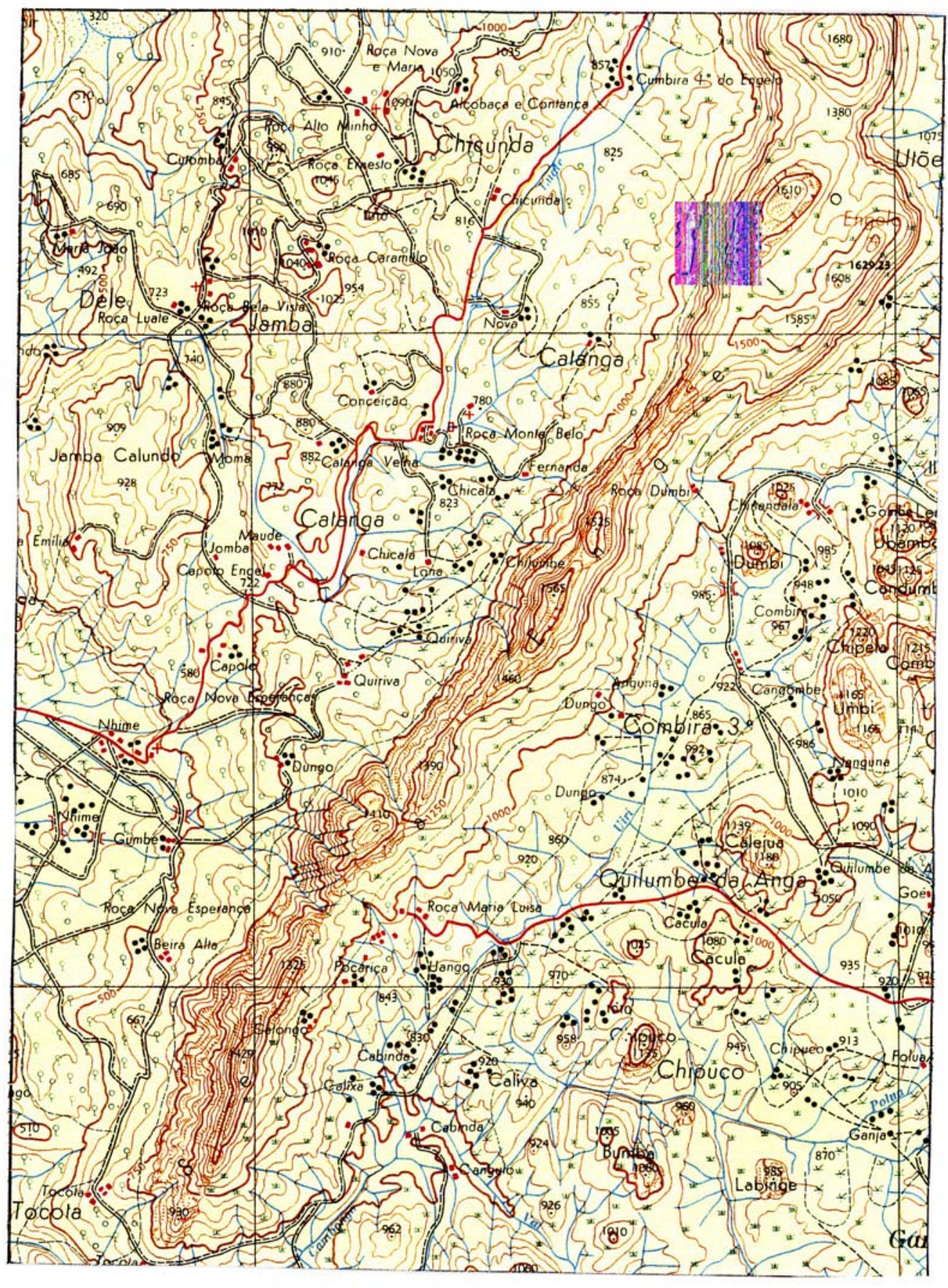

Fig. 4 - A Serra do Engelo, entre lat. $11^{\circ} 10^{\prime}$ e $11^{\circ} 15^{\prime}$ e long. $14^{\circ} 15^{\prime}$ e $14^{\circ} 20^{\prime}$, na escala 1:100 000 

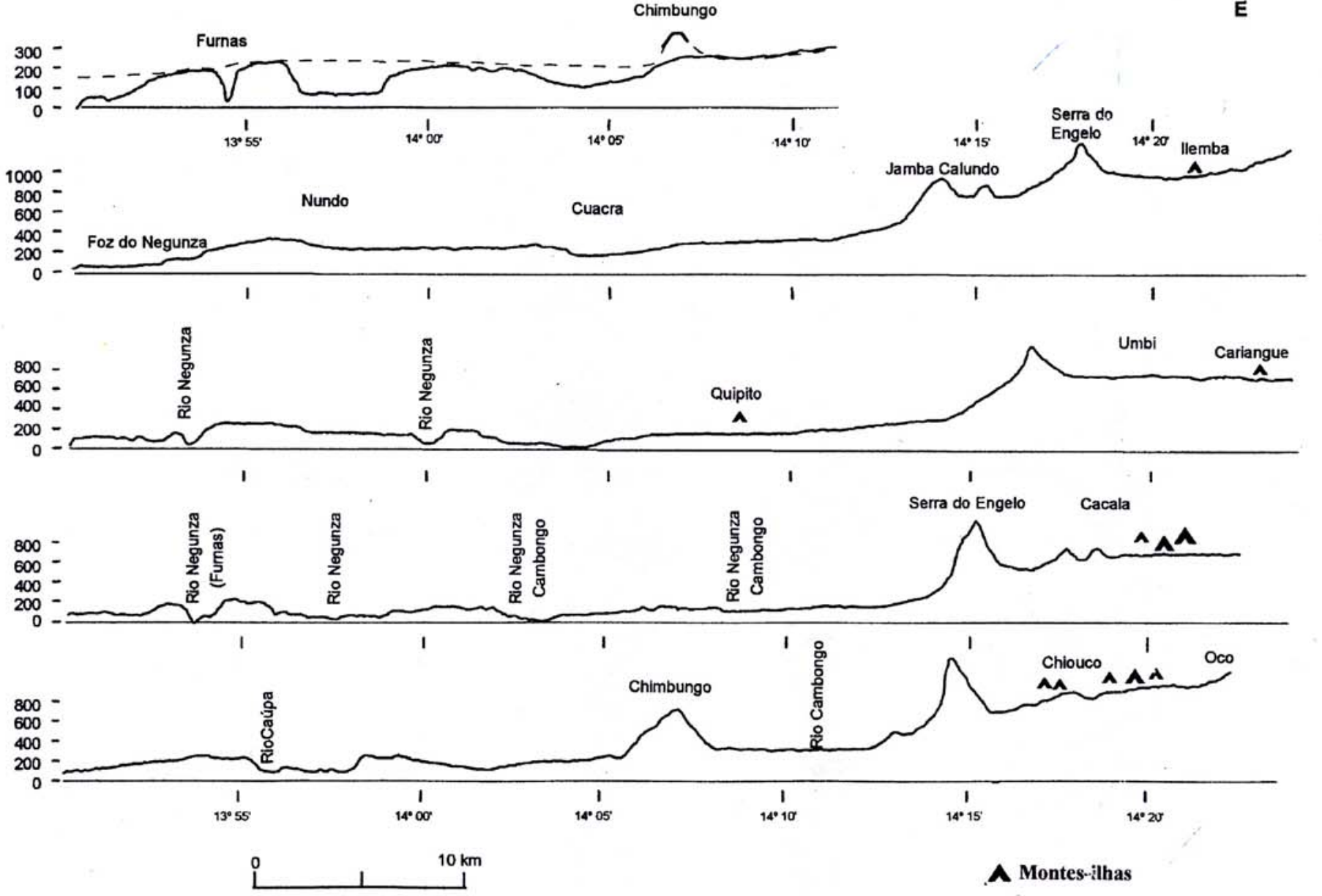

Fig. 5 - Perfis topográficos do litoral à Serra do Engelo 


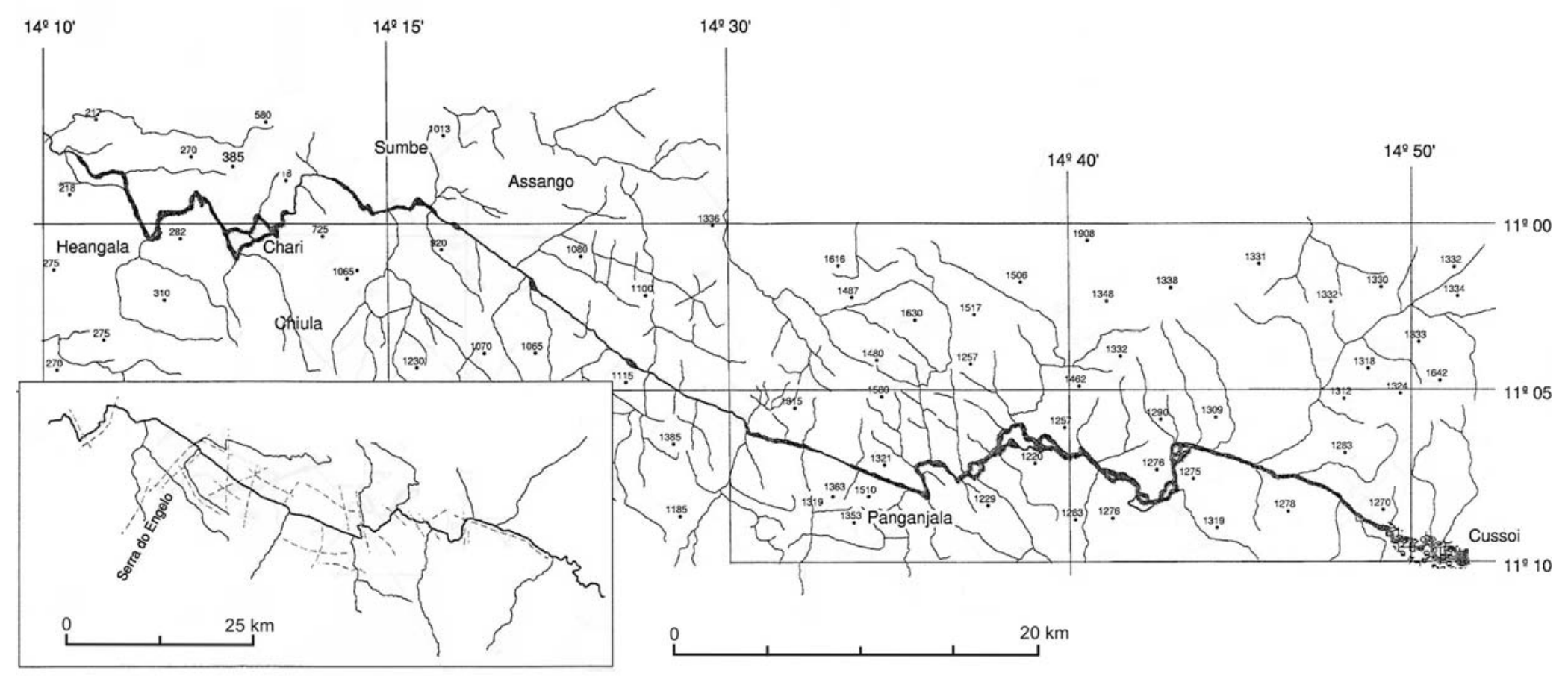

Fig. 6 - O traçado do rio Cuvo ou Queve entre Cussoi e Heangala e de alguns afluentes, reveladores de fracturas e falhas (estas a tracejado na figura do canto inferior esquerdo). 


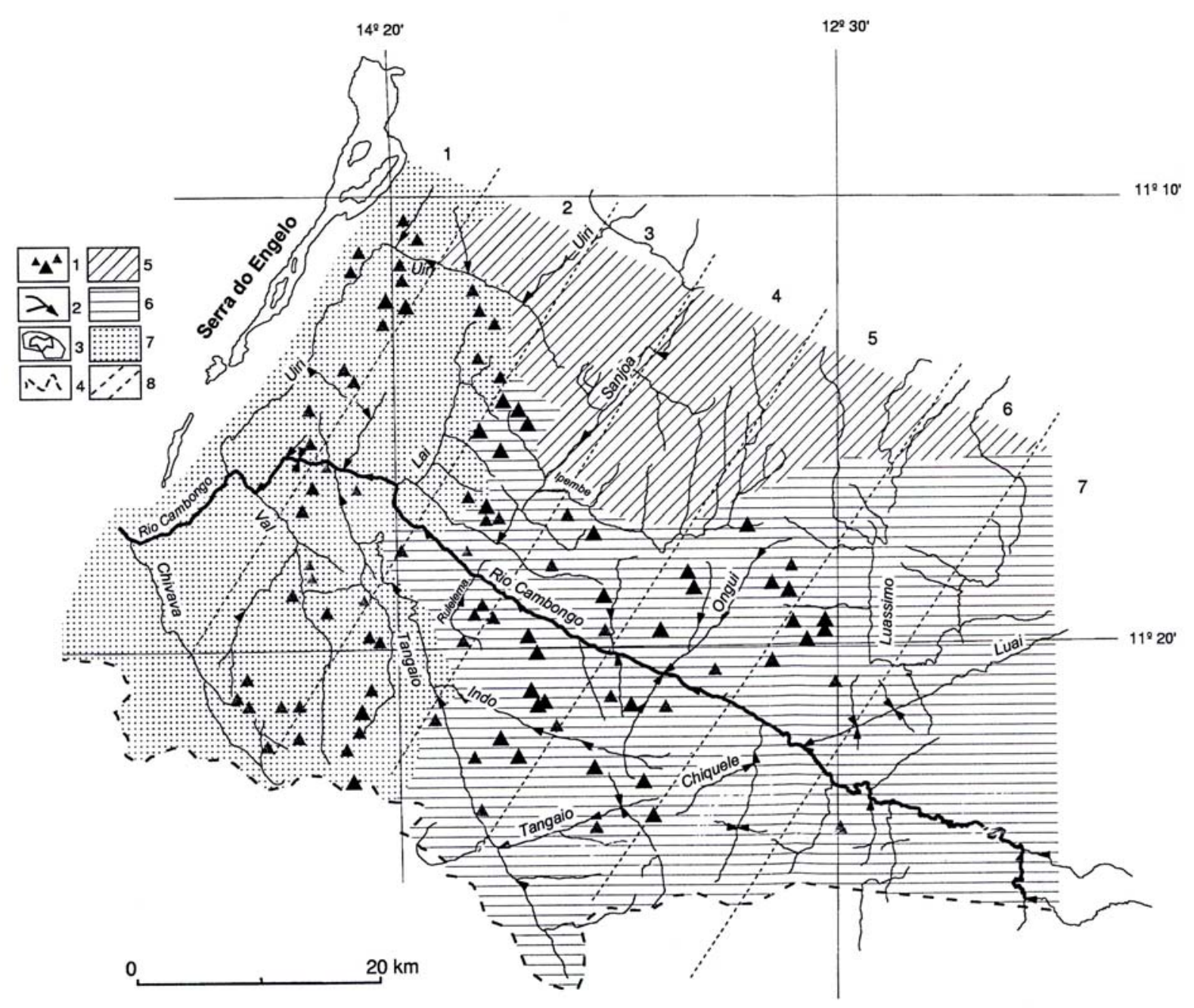

Fig. 7 - Inselberg ou montes-ilhas e vales de fractura a leste da Serra do Engelo 